\title{
Universidad Nacional de
}

\section{La Plata}

Facultad de Periodismo y

Comunicación Social

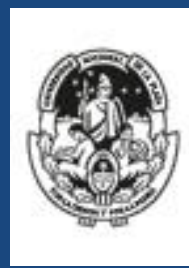

Doctorado en Comunicación

"Rompiendo el silencio: la construcción discursiva de la libertad en las líricas de rockpop argentino durante el período 1982-1989"

Tesista:

Lic. Cristian Secul Giusti cristiansecul@gmail.com

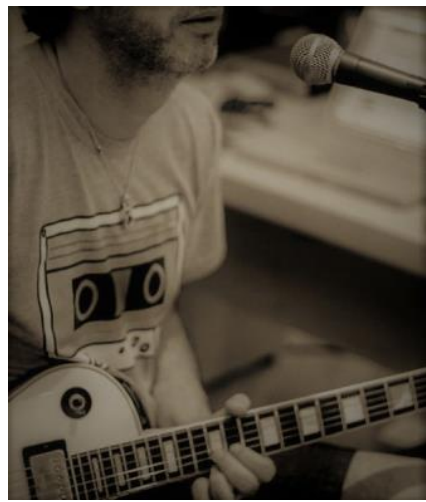

Directora:

Dra. Rossana Viñas

Co-Directora:

Prof. Alejandra Valentino 


\section{Índice}

\section{Agradecimientos}

\section{Capítulo I}

1. A modo de Introducción............................................

1.1. Primeras aproximaciones al trabajo.................................. 7

1.2. Presentación ............................................................ 8

1.3. Justificación del tema............................................. 8

1.4. Estado del arte.....................................................11

1.5. Presentación del tema-problema................................... 17

1.6. Preguntas de investigación....................................... 17

1.7. Fundamentación..................................................... 17

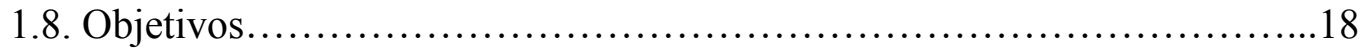

a) Objetivo general............................................. 19

b) Objetivos específicos.........................................19

1.9. Hipótesis........................................................ 19

1.10. Estructura capitular del trabajo....................................20

\section{Capítulo II}

2. Marco teórico.........................................................23

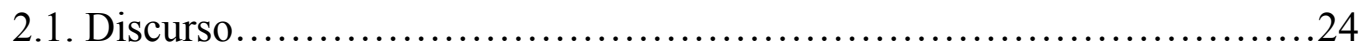

2.1.1. El discurso como práctica social.............................25

2.1.2. La letra de rock y el discurso social..........................27

2.1.3. Las letras de rock como género discursivo........................30

2.1.4. Las letras de rock en un marco dialógico........................32

2.1.5. Música y versos integrados...................................34

2.1.6. En torno a la dimensión retórica.................................37

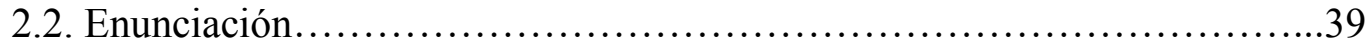

2.2.1. La teoría de la enunciación..................................40

2.2.2. Huellas y subjetividades.....................................41

2.2.3. La enunciación en las letras de rock..........................43

2.3. Libertad......................................................... 44 
2.3.1. Un entorno de negociación y clasificación.......................47

2.3.2. La distinción negativa y positiva................................49

2.3.3. La pregunta sobre la libertad....................................51

2.4. Transición democrática............................................52

2.4.1. La transición democrática argentina............................54

2.4.2. Democracia y libertad.........................................55

2.5. Cultura Rock.....................................................5 57

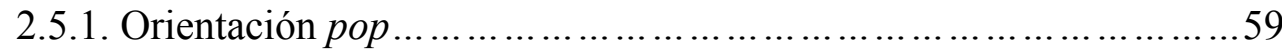

2.5.2. Los términos del new wave ..........................................61

2.5.3. El rock argentino: escena, práctica y debate......................63

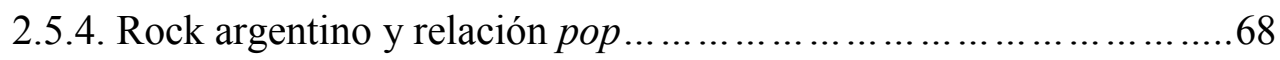

2.5.5. Identidad corporal........................................70

2.5.6. Rock argentino: entre la autenticidad y decisión comercial..........71

2.6. Jóvenes......................................................... 74

2.6.1. La concepción de subculturas.................................75

2.6.2. Cultura rock y tensiones juveniles.............................77

2.6.3. El rock argentino y la pregunta juvenil...........................78

\section{Capítulo III}

3. Marco temporal: aproximaciones al escenario histórico (1982-1989)...........81

3.1. Un escenario político-social de reconfiguración.........................81

3.1.1. Apertura democrática........................................83

3.1.2. Aproximaciones cotidianas................................... 85

3.1.3. Avance en retroceso......................................... 86

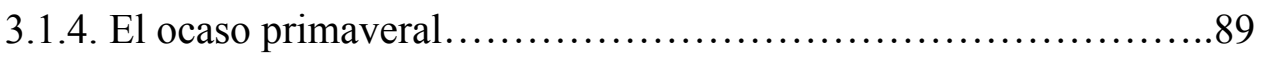

3.1.5. El final adelantado..........................................90

3.2. La escena del rock argentino (1982-1989)........................... 90

3.2.1. Rock y Dictadura.........................................93

3.2.2. Malvinas y después.......................................94

3.2.3. Underground y reconfiguraciones..............................95

3.2.4. El rock argentino, en contexto primaveral......................97

3.2.5 El camino del pop...........................................99

3.2.6. Al calor de las masas......................................... 100

3.2.7. Los jóvenes y la transición................................... 102 
3.2.8. Entre la exportación y el desencanto. 103

\section{Capítulo IV}

4. Recorrido metodológico: la puesta en curso del análisis.....................107

4.1. La puesta en curso del análisis.....................................107

4.2. Trayectos metodológicos...........................................107

a) En torno a los objetivos y los propósitos de la investigación..........107

4.3. La construcción del corpus........................................108

4.4. En torno a la contextualización.....................................114

4.5. Procedimientos analíticos............................................ 118

a) Sobre la funcionalidad de la tematización..........................118

b) Sobre la referencia deíctica...................................120

c) Modalidades de enunciación y de enunciado......................122

d) Polifonía: presencia de distintas voces en los enunciados............127

\section{Capítulo V}

5. Transición, retirada militar y construcción discursiva de la libertad..............130

5.1. Rock/pop argentino: el diálogo con el pasado reciente....................132

5.2. Análisis de las líricas.............................................. 133

5.2.1. Es necesario cantar de nuevo...............................134

5.2.2. Libertad para sentir y para amar...............................139

5.2 3. La vida es nuestra............................................ 142

5.2 4. Hay un destino nuevo.........................................146

5.2 5. Para que exista mañana.......................................150

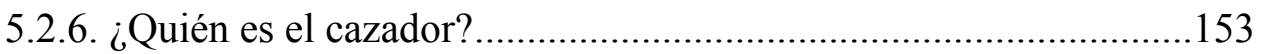

5.2.7. Ya no sirve vivir para sufrir.................................156

5.2 8. Siempre estás naciendo, libertad.............................159

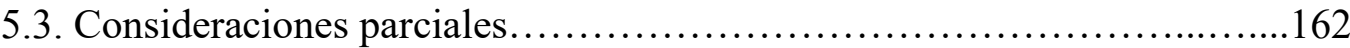

\section{Capítulo VI}

6. Una estrategia de defensa.................................................. 164

6.1. La libertad como centralidad democrática...............................164

6.1.2. Jóvenes en transición.........................................165

6.1.3. La búsqueda de libertad..................................167 


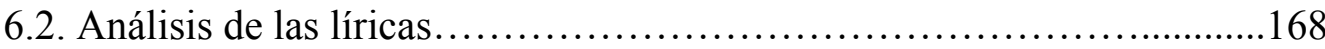

6.2.1. La energía de ir a más.........................................169

6.2.2. Arte de los decididos........................................173

6.2.3 Para elegir y actuar............................................. 176

6.2.4. No somos los mismos.......................................178

6.2.5. Arrancar todo lo que me hiera..................................181

6.2.6. Salí a la calle................................................. 183

6.2.7. Un rock and roll que me sacuda la cabeza........................185

6.2.8. Somos más hermanos que antes................................189

6.2.9. Contentos de estar vivos.......................................191

6.3. Consideraciones parciales.................................... 193

\section{Capítulo VII}

7. Una política de frivolidad: la construcción de la libertad en la cotidianeidad...195

7.1. Una temática corporal.........................................195

7.1.2. Postura y baile............................................197

7.1.3. Baile y entretenimiento...................................... 198

7. 1.4. La política del humor.....................................200

7.2. Análisis de las líricas..........................................201

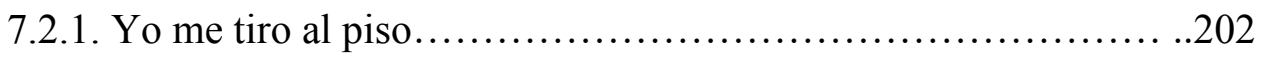

7.2.2. A girar, todos a bailar....................................205

7.2.3. Que nos dejen bailar....................................207

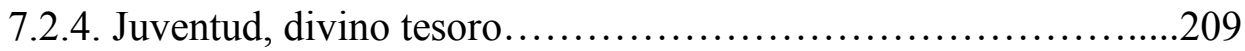

7.2.5. Ya se van las luces......................................212

7.2.6. No me preocupa parecer vulgar........................... 215

7.2.7. Sacude tu cuerpo libre.....................................219

7.2.8. Es el éxtasis total.......................................222

7.3. Consideraciones parciales....................................224

\section{Capítulo VIII}

8. Una libertad en tensión:

el yo en perspectiva, entre el aislamiento y el escape.......................227

8.1. La profundización de la primera persona........................227

8.1.2. El espacio de la individualidad ¿una clave posmoderna?............229 
8.1.3. La libertad del aislamiento y la huida. .231

8.2. Análisis de las líricas...........................................232

8.2.1. Libre o dentro de una jaula..................................234

8.2.2. Me veo en la jaula........................................236

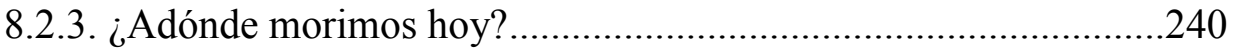

8.2.4. Atrapados por la misma red...............................244

8.2.5. Temiendo un nuevo dolor.................................246

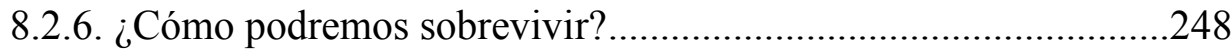

8.2.7. Bajo un cielo tan igual....................................250

8.2.8. La cuota de mi libertad....................................252

8.3. Consideraciones parciales.................................255

\section{Capítulo IX}

9. Entre la libertad y el desencanto. Claves y pistas de una nueva enunciación...257

9.1. Las expectativas truncas....................................257

9.1.2. Una temática de resignación y desengaño......................258

9.2. Análisis de las líricas...........................................260

9.2.1. Ahora no estoy más tranquilo...............................261

9.2.2. Voy quedando solo cada vez más..........................264

9.2.3. Al vacío..................................................267

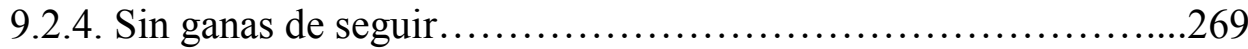

9.2.5. Salgo a bailar con mi malestar.............................272

9.2.6. Destruir tu cuerpo es liberación.................................274

9.2.7. Mejor salir.............................................279

9.3. Consideraciones parciales...................................281

\section{Capítulo X}

10. Consideraciones finales...........................................283

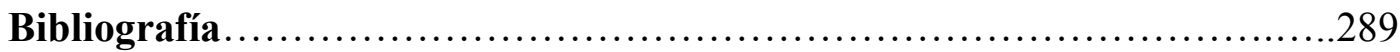

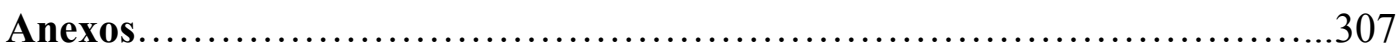




\section{Agradecimientos}

Para Lilian y Fernando, mis viejos hermosos.

Para Tati, mi compañera y cómplice.

Para Ro y Ale por ayudarme, enseñarme y guiarme en el recorrido.

Para mi querida Facultad de Periodismo y Comunicación Social, por darme las herramientas y los recursos para mejorar la cotidianeidad con palabras y hechos.

Para la gente y el espacio del CILE, por brindarme el marco necesario para llevar a cabo una idea que hoy se hace realidad.

Para mis maravillosxs compañerxs de doctorado, Angie, Ceci, Estani y Luli por los debates, las risas, las discusiones y las proyecciones políticas.

Para mis amigxs de acá y de allá, lxs que siempre están y saben que pueden contar conmigo.

Para todxs lxs que han contribuido con este trabajo con recomendaciones e ideas.

Para la cultura rock que desde los ocho años me instruye, renueva y reconforta.

Por todo esto, aunque me fuercen, nunca voy a decir que todo tiempo por pasado fue mejor; mañana es mejor.

Cristian 


\section{Capítulo I}

\section{A modo de introducción}

\subsection{Primeras aproximaciones al trabajo}

El presente trabajo aborda la construcción discursiva de la libertad presente en las líricas del rock argentino del período 1982-1989. El propósito del mismo consiste en revalorizar los impulsos estéticos y diferenciales propuestos por el discurso del rock argentino (en su vertiente estilística denominada $p o p$ ) a partir del análisis lingüístico y el estudio de las estrategias enunciativas articuladas en sociedad.

La temática que construyen discursivamente las letras de rock-pop argentino del período 1982-1989 admite la posibilidad de un estudio de la discursividad social, a fin de ampliar los límites de comprensión e investigar algunos de los sentidos que circulaban en un período contextual determinado.

En consecuencia, la investigación que se ha planteado en esta tesis doctoral fue articulada a partir de una noción de discursividad y en función de un abordaje contextual de los textos, entendiendo su situación social e histórica y abordando la enunciación producida. En este sentido, las siguientes líneas reflexionan sobre el rol discursivo y social de las letras de rock argentino durante el lapso correspondiente de la década del 80 y comprende las negociaciones, voluntades y entramados que convivieron durante la instancia de transición democrática.

El rock argentino desempeñó un papel importante en la socialización de los jóvenes, quienes durante la democracia buscaron la autonomía y la efectiva puesta en acción de sus libertades. Por esto mismo, el actual trabajo estudia a las letras de rock argentino como discursos que, desde el final de la dictadura cívico militar y en función del advenimiento democrático, promovieron una producción de sentido relacionada con la consagración de libertades, la consolidación de la democracia, las identidades juveniles y la valorización de la diversidad. 


\subsection{Presentación}

Como se mencionó, esta tesis doctoral se ocupa en analizar los discursos de las líricas del rock argentino producidas durante el período 1982-1989, tomando como puntos de referencia la finalización de la guerra de Malvinas (14 de junio de 1982) y la conclusión forzosa del gobierno radical del ex presidente Raúl Alfonsín (8 de julio de 1989). En función de ello, a partir del análisis de la construcción discursiva de la libertad y las tematizaciones que articulan las líricas en el transcurso del período, es posible destacar una nueva configuración en el rock argentino que integró un mapa de negociaciones y manifiestos distintivos, y abordó a la vertiente pop como un enlace evidente luego del conflicto bélico en el atlántico sur.

El desarrollo de la orientación pop del rock argentino resulta importante en su abordaje porque se desenvolvió artísticamente en un marco de transición democrática y de restitución de libertades. Este último proceso, que se inició luego del enfrentamiento en Malvinas, incluyó la consiguiente recuperación de un sistema democrático constituido desde el liberalismo político y finalizó su etapa a causa de la renuncia de Alfonsín y la profundización del neoliberalismo económico conducido por el ex presidente Carlos Menem a partir del 8 de julio de 1989.

\subsection{Justificación del tema}

El acercamiento al marco contextual presente en este trabajo incluye cuestiones vinculadas a la cultura rock argentina -entendiéndola como un universo masivo e identitario que atraviesa generaciones y prácticas- y a las problemáticas políticas y sociales que tuvieron relevancia decisiva en la escena de transición democrática de la Argentina. La significación de la temporalidad seleccionada permite comprender entonces un escenario que desde las líricas, sugiere distintos estados, intereses y tensiones. Sin dudas, esta trama no se encuentra ajena del discurrir histórico y por lo tanto, propone debates en relación con acontecimientos que anteceden a la dictadura cívico militar instaurada en los años 1976-1983.

Por tanto, vale decir que el período seleccionado para la investigación contiene un rechazo hacia el autoritarismo y la represión desatada durante la última dictadura cívico militar. Del mismo modo, advierte la complejidad del concepto transición democrática 
en los discursos que articulan las letras y aborda también la presencia representativa de la denominada primavera democrática post-dictatorial en relación con las expectativas generadas por el gobierno constitucional del ex presidente Raúl Alfonsín en sus años iniciales (1983-1985).

La coyuntura histórica que se aborda en la tesis doctoral articula un léxico reconfigurado a partir de enunciados, términos, expresiones, significados y usos del lenguaje que integraron un lenguaje determinado y correspondiente. Por esto mismo, es posible pensar que la temporalidad, la duración y el campo de aplicación de estos repertorios definieron un universo de lo enunciable y de lo concebible en relación con lo discursivo (Bonnin, 2015: 225).

En suma, este trabajo de tesis doctoral se construyó también a partir de una motivación de revisión histórica, contemplando así las ideas y acciones políticas, culturales y sociales que llevaron a la Argentina a vivir una instancia de transición democrática, luego de años de violencia política y de terrorismo de estado a partir del golpe cívico militar de 1976.

En la constitución de la tesis doctoral se buscó reunir pensamientos y reflexiones desde el análisis discursivo de las letras de rock argentino, comprendiéndolas como piezas discursivas atravesadas por una coyuntura histórica y por una memoria del pasado reciente que dan cuenta de diferentes nociones de construcción colectiva y/o individual en sociedad.

En este sentido, en las próximas líneas se aborda una política de reconstrucción y de profundización del pasado reciente desde una instancia cultural y pos-dictatorial, que se enlaza con la política de memoria iniciada en el año 2003 por el ex presidente Néstor Kirchner y que finaliza como política de estado en 2015, tras la conclusión del mandato de Cristina Fernández de Kirchner. Este proceso de profundización política sobre la memoria y los acontecimientos del pasado activaron una elaboración reflexiva sobre el actuar de la sociedad argentina en un marco de dictadura y en relación con un desempeño posterior, en un contexto de democracia y rehabilitación de un estado de derechos.

Por tanto, uno de los propósitos primordiales de esta investigación refirió inicialmente a la historización del rock argentino, atendiendo las propias panorámicas de su tránsito cultural y/o político que resulta inseparable, inherente y esencial para comprender las construcciones del contexto. Así, es posible pensar que el trabajo contribuye a una búsqueda de representación y a una intención de actualización y promoción de la 
escritura en relación con la cultura rock, el estudio del discurso y la contemplación del pasado reciente.

En función de ello, la construcción discursiva de la libertad presente en las líricas se articula desde instancias diversas y en función de los espacios de reflexión y debate convocados por los esquemas enunciativos planteados en las líricas de rock argentino. Por consiguiente, las perspectivas que se bifurcan en las letras son trascendentales para comprender los cuadros dialógicos y discursivos que se activan y retroalimentan en un marco de espacio social. A partir de ello, las líricas reconocen modos de ver y sentir social que mutan y que destacan argumentos críticos, vinculados con desigualdades y complejidades propias de un país en reconstrucción.

Las letras seleccionadas como corpus analítico poseen una destacada riqueza discursiva y permiten abordar un sucinto análisis en el campo de las ciencias sociales en general. Es por ello que el actual trabajo ofrece una visión analítica sobre la década del 80 en la Argentina, considerándola como una etapa relevante y significativa para comprender las prácticas sociales en democracia. Este es uno de los rasgos más importantes de la actual tesis doctoral porque se aborda a la década del 80 desde una instancia de interés y relevancia. En efecto, el período es comprendido como una etapa fundamental que habilitó nuevamente el universo de la política en la sociedad argentina y acompañó el tránsito de la concertación y la integración cultural en el país luego de los años dictatoriales. Sin dudas, la impronta de esta reconfiguración se consolidó en torno al ideario discursivo de la democracia y la puesta en común de los derechos civiles.

Siguiendo esta línea, la cultura rock local ocupó un lugar central en la producción del sentido de la época y legitimó las discusiones, las búsquedas y las inquietudes de las juventudes en tiempos de la recuperada democracia. Se constituyó así un eje discursivo que tendió a reflexionar sobre la libertad y las consideraciones de ser libre en un nuevo universo de constitución social. A partir de ello, surgieron nuevos modos de describir la realidad, apelando a construcciones individualistas, irónicas y des-dramatizadoras que se apartaron de nociones netamente de protesta o de los relatos deterministas y/o definitorios en torno a lo político y social del país.

En este sentido, se coloca injustamente a la década del 80 como una etapa perdida, frívola (denostada bajo el rótulo de poptimista) y carente de sentido o de márgenes políticos. Por esta razón, y con la intención de sumar a un debate que amplifique la perspectiva y genere nuevos criterios, el actual trabajo busca complejizar las dicotomías, en pos de articular una mirada discursiva de las letras del rock argentino y 
de incluir una reflexión intensa sobre las temáticas de libertad propuestas por dichos relatos líricos.

\subsection{Estado del arte}

El rock es un fenómeno sociocultural que propone prácticas culturales y establece vínculos de identidad y comportamiento social que se enfrentan al orden institucional de un modo estético y artístico. Particularmente, el rock argentino se enmarca en una trama cultural alimentada de negociaciones, rechazos y apropiaciones que, fundamentalmente, postulan y ansían un ideario de libertad desde distintas perspectivas. Por lo tanto, la elección temporal constituida en el actual trabajo convoca a un recorte específico e ilustrativo que se relaciona con la tematización de la libertad presente en el corpus de letras seleccionado.

El período que transcurrió entre los años 1982 y 1989 significó un marco fructífero para el rock argentino y permitió el auge del rock-pop como nueva forma de expresión musical dentro del movimiento del rock argentino. Este escenario resaltó las marcadas influencias del punk (género de ruptura por excelencia), new wave (término que engloba a la "nueva ola de música rock" y se utiliza generalmente para definir un derivado del punk rock) y hasta de los componentes bailables de la música disco (antes denostada por los líderes del rock vernáculo y tolerada en instancias mayores durante la década del $80)$.

El proceso histórico habilitado durante los años 1982-1989 contuvo altos índices de expectativa en la sociedad, configuró nuevas transformaciones y profundizó sentidos de libertad producidos a causa del fin de la dictadura cívico militar y el desarrollo de la guerra de Malvinas. En este sentido, el rock argentino se ubicó como una compañía de diagnóstico y un testigo de época que realizó asimilaciones y observaciones sobre el contexto desde diferentes perspectivas. A partir de ello, distintos trabajos efectuaron lecturas y análisis sobre la función cultural del rock argentino en un marco de transición democrática y distribución política, cultural y social en un cuadro de estado de derechos.

En este aspecto, la construcción del estado del arte se llevó a cabo en función del estudio de periodistas, investigadores y escritores que aportaron diversas miradas sobre el campo del rock argentino y la cuestión libertaria. Por consiguiente, es posible visualizar concepciones distintivas en ciertos trabajos que si bien toman de un modo 
muy lateral la tematización de la libertad, abordan el fenómeno social del rock, y destacan los giros significativos que produjo en los modos de decir y de actuar de gran parte de la sociedad:

a) Rockología, documentos de los 80, es un trabajo escrito por el periodista y escritor Eduardo Berti que pone en cuestión la situación del rock durante la década del 80. Por esto mismo, toma como punto de partida la Guerra de Malvinas y organiza los capítulos por tópicos que dan cuenta de las transformaciones sufridas dentro y fuera del rock argentino (y también mundial).

De acuerdo a lo revelado por el sociólogo Simon Firth, Berti establece cinco modos de concebir la cultura rock:

- se la subraya como una expresión adolescente, cercana al folk y las introspecciones personales;

- se la asocia a la contracultura de los sesenta;

- se la vincula a una forma artística (los discos son pensados como obras de arte y como objetos culturales de suma importancia);

- se la concibe bajo una estética de masas, tomando como referencia las reflexiones de la Teoría Crítica (Theodor Adorno y Max Horkheimer);

- Se la piensa desde la cultura de masas, pero teniendo en cuenta las teorías delineadas en la Escuela de Birmingham y la relación del rock con la sociedad de consumo.

Tomando en consideración estos apartados, el libro destaca el incremento de producción que tuvieron los discos en la década del 80 , sobre todo durante la etapa de primavera democrática (1983-1985). El autor reflexiona sobre el estilo fragmentario de las líricas de las bandas que emergieron luego del conflicto de Malvinas (Los Twist, Soda Stereo, Viudas e Hijas de Roque Enroll, por ejemplo) y resalta las transformaciones artísticas que presentaron los históricos del movimiento (Charly García y Luis Alberto Spinetta, principalmente). En función de ello, se comparan los aspectos metafóricos de otras épocas (atravesadas por la censura y las dictaduras de 1966-1973 y 1976-1983) y los giros líricos que aparecieron a finales del régimen militar, menos predispuestos a contar historias a modo de cuento y más cercanos a frases breves y rupturistas.

Berti sostiene que durante la década del 80 se observó una intromisión muy fuerte del mercado y el negocio en el mundo del rock. En el caso argentino, se exhibió una proliferación de sponsors y festivales que dieron cuenta de la rentabilidad de la música 
juvenil. Esto último también se vinculó con la exportación de las bandas argentinas a los países limítrofes, en un principio, y a toda América Latina o España hacia finales de la década, siendo Soda Stereo un referente indiscutido del rock argentino en el exterior.

El rock de los 80 se vinculó entonces con una noción democrática y forjó una relación inédita con la política. Para ejemplificar, Berti brinda dos aspectos interesantes: por un lado, destaca la decisión de Charly García de firmar solicitadas a favor de la campaña de Raúl Alfonsín en 1983 y, por otro, la participación de Man Ray o los Ratones Paranoicos en los actos electorales del radical Eduardo Angeloz (candidato presidencial de 1989).

Por tanto, Rockología es una obra que permite apreciar las transformaciones artísticas y sociales que vivenció el rock argentino en un escenario inédito que condensaba expectativas. Es un trabajo fundamental para entender los procesos que se realizaron en el rock de la década del 80. De hecho, las entrevistas que integran la obra son esclarecedoras y brindan discusiones y detalles de época que contribuyen a la construcción del contexto que abarcan las líricas que analizamos en esta tesis.

b) Rock del país, una mirada de la cultura juvenil argentina en los ochenta es una tesis de investigación en Comunicación Social que interroga las problemáticas tratadas por los grupos de rock en una etapa de transición democrática. Para ello, Alcira Martínez y Leandro Cantelli toman como objeto de estudio las columnas de la histórica periodista de rock Gloria Guerrero, escritas para la representativa revista Humor y agrupadas en una compilación denominada "Historias del Palo (1981-1994)", editado en 1995.

En función de ello, el libro contiene artículos que diagraman la situación del rock argentino durante el período 1981-1994 y, del mismo modo, expone entrevistas que la periodista les realizó a distintos artistas representativos de la escena rockera argentina. De esta manera, se describe la llegada a la masividad de Seru Giran y su pronta disolución, la postura del rock argentino ante la trágica Guerra de Malvinas (y su participación en el polémico Festival por la Solidaridad Latinoamericana organizado por las Fuerzas Armadas y agrupaciones civiles), las consecuencias benefactoras que trajo la democracia (en consonancia directa con una época de consumo y diversión) y la idea del rock argentino como modelo de exportación.

Sin dudas, dichas entrevistas son de suma importancia, puesto que los músicos (Charly García, Gustavo Cerati, Federico Moura o Miguel Abuelo, entre otros) consideran que 
la década está inaugurando una era que da un nuevo lugar a las estéticas juveniles, el uso de tecnologías novedosas, la violencia en los recitales masivos y la resignificación del compromiso de los jóvenes en términos políticos y culturales.

En consecuencia, la época abordada en el trabajo de Cantelli y Martínez es también la fracción de tiempo que se abarca en la presente tesis doctoral. Los autores proporcionan una reflexión sobre las diferentes vertientes de pensamiento que se desarrollaron en el rock de los $80 \mathrm{y}$, de hecho, se habla a las claras de una necesidad de expresión urgente. Resulta relevante entonces la postulación de una democracia al amparo de las instituciones y las interpelaciones generadas por el Estado de derechos a partir del ingreso de los jóvenes como protagonistas de una transformación posible.

Para entender esto último, los autores emplean los conceptos juventud, posmodernidad o consumo cultural con el propósito de lograr una mayor profundización de las problemáticas que contrajo la década del 80 . Por consiguiente, la tesis señala que la democracia argentina logró que el rock argentino generara un nuevo mercado vital y de exportación que, a partir de las nociones de posmodernidad, advirtió una sociedad de consumo signada por objetos culturales: una sociedad de consumo construida a partir de objetos materiales que tienen una vida útil prolongada (Cantelli y Martínez, 2009: 22$80)$.

c) Gabriel Correa, en su artículo académico, "El rock argentino como generador de espacios de resistencia" (2002) explora aspectos de la historia del rock argentino que señalan ideas en relación con la conformación de determinadas producciones artísticas como "espacios de resistencia”. Este último está pensado como un concepto que permite un lugar artístico y proporciona "algún tipo de respuesta o vía de canalización a las presiones que ejerce el hábitat local de lo cotidiano" (2002: 40).

La resistencia, en estos términos, consiste en enfrentarse de un modo estético y lírico ante un poder desmedido que busca normalizar, disciplinar y hasta anular al otro. Ese poder que busca inhibir puede estar representado en una persona, una institución o un sistema de relaciones. Correa sostiene que una canción es un "espacio de resistencia" que refleja pulsiones y se identifica con lo otro que no se quiere ser ni ver. En virtud de ello, el investigador/docente sostiene que a principios de la década del 80 se comenzó a utilizar el concepto de "rock nacional" como un aspecto englobante, sobre todo, a partir de la derrota de la guerra de Malvinas. 
Asimismo, conviene subrayar la significativa analogía que enfatiza el autor entre el rock and roll de los 50 y el rock argentino de los primeros años de democracia. La idea de "baile/entretenimiento" cobró valor en esta etapa y el rock entró en las discotecas resignificando viejas costumbres y con un nuevo apellido: rock-pop. Este nuevo modo de vivir y de hacer música en democracia trajo consigo un cimbronazo que desdibujó aquella visión de comunión ideológica de las etapas dictatoriales, en los 80 los músicos conviven con distintos intereses.

e) La Tesis de Grado en Comunicación Social de la Facultad de Periodismo y Comunicación Social de la Universidad de La Plata "Si tienes voz, tienes palabras: Análisis discursivo de las líricas del rock argentino en la 'primavera democrática' (1983 - 1986)" (2011) de los investigadores Cristian Secul Giusti y Federico Rodríguez Lemos analiza discursivamente la situación social y cultural argentina desde la lírica del rock argentino durante los tres primeros años de la recuperación democrática (1983-1986). El trabajo estudia las huellas contextuales y discursivas presentes en las letras de los discos "Clics Modernos (1983)" de Charly García, "Soda Stereo (1984)" de Soda Stereo, "Locura (1985)" de Virus y “Oktubre (1986)" de Patricio Rey y Sus Redonditos de Ricota. Por esto mismo, dicha tesis construye una mirada analítica desde el plano de la discursividad y los vínculos con un contexto de apertura social y política. En este sentido, la tematización en torno a la libertad se aprecia de un modo breve, pero precisa una situación de nuevo tiempo que oscila entre el terror dictatorial y el efectivo estado de derecho de la democracia.

Siguiendo este camino, el trabajo da cuenta de un empleo de lenguajes en las líricas que permiten poner en tensión el carácter lineal o "transparente" de las letras. De esta manera, la tesis habilita un universo de interpretaciones que no se contemplan de un modo unidireccional, sino diverso y también ambiguo en relación con las estrategias discursivas articuladas en las letras de rock argentino (2011: 34).

f) Sobre el aspecto ético de las líricas del rock, conviene remitirse al artículo “¿Tiene moral el rock?” (2009) del filósofo Ramón Sanz Ferramola porque interroga sobre la incidencia de las valoraciones en torno a la libertad en un marco de cultura juvenil y alternativa o contracultural. Es por ello que el autor encuentra una respuesta que resulta interesante para profundizar, puesto que aprecia la posibilidad de abordar la libertad como una moral entendida desde la autonomía y el pluralismo. 
En este sentido, la pregunta sobre la libertad sirve para forjar un camino de representación para pensar en conjunto: "la puerta de entrada a una de las cuestiones centrales de la ética en tanto reflexión sobre la moral (es) la libertad y los distintos modos de entenderla" (2009: 123).

En sintonía, el artículo permite pensar la libertad y su adscripción en referencia al universo de rock y sus actos de acción y voluntad mediante las líricas y las propias estéticas musicales. Así, Sanz Ferramola destaca acepciones relativas a la comprensión de la libertad como acto voluntativo y práctico. Por esto mismo, su definición en un marco de cultura rock se configura a partir de una vinculación directa con la esfera contextual que las acompañan.

Por esta razón, la libertad se adscribe a personas y/o a acciones en virtud de ciertas condiciones sociales y culturales que profundizan y marcan el aspecto dialéctico de la libertad de actuar y ejercer en sociedad. Mientras que la primera requiere de un medio institucional y social para su despliegue, la segunda remite a la capacidad normativamente estructurada de una persona de acuerdo a un contexto determinado. Estos aspectos, se presume, sirven para el análisis de las líricas de rock porque articulan postulaciones de libertades de acción y voluntades de liberación relacionadas con un período de apertura y rechazo de un pasado dictatorial.

La presentación de antecedentes pone de manifiesto las significaciones del rock argentino en la convulsionada década del 80 y la problemática de la libertad con el propósito de vincular prácticas realizadas en sociedad. Por esta razón, los abordajes de estos autores parten desde un repaso histórico de la cultura rock argentina durante la década del 80 , considerando características en torno a su ubicación comercial y de reflexión sobre lo juvenil, hasta la significación de una nuevas estructura social para comprender la función cultural del rock en una sociedad pos-dictatorial.

De esta forma, el estudio de las producciones de sentido vinculadas con el universo de la cultura rock y sus experiencias circundantes (letras, escenarios, vestuarios, sonidos) permiten comprender visiones y paradigmas sobre las juventudes, la política y la cultura en términos generales. En consecuencia, el estado de la cuestión se constituyó a partir de un andamiaje de nociones heterogéneas y dinámicas sobre el carácter libertario de la vida y sus múltiples disputas de sentido desde contextos diversos. 


\subsection{Presentación del tema-problema}

La tematización de la libertad en las letras del rock argentino publicadas durante el período de transición democrática (1982-1989), desde la finalización de la guerra de Malvinas hasta la renuncia del presidente constitucional, Raúl Alfonsín.

\subsection{Preguntas de investigación}

- ¿Cómo se construye discursivamente la tematización de la libertad en las letras del rock argentino producidas durante el período 1982-1989?

- ¿Cuáles son las estrategias enunciativas que se articulan en las líricas para dar cuenta del contexto?

- ¿Qué construcción temática de la libertad presentan las líricas en relación con las experiencias juveniles en democracia?

- ¿Cuál es la inscripción discursiva que componen los actores sociales en la construcción discursiva de la libertad?

\subsection{Fundamentación}

El presente trabajo de investigación doctoral aborda una reflexión sobre el lenguaje y los sentidos explícitos e implícitos que se enraízan en la trama cultural de una sociedad. Se propone entonces, un análisis discursivo de las letras de rock a partir del estudio de los diferentes fenómenos lingüísticos y mecanismos de construcción del sentido social. Las piezas discursivas se configuran como elementos centrales para comprender el vínculo comunicativo y las articulaciones discursivas que se emplean a partir de la tematización de la libertad expuesta en el corpus de líricas.

Así, la constitución del corpus se fundó a partir de líricas que advierten un alcance temporal determinado (1982-1989) y tematizan a la libertad en sus discursos. Ante esto, el corpus se regularizó y reflexionó en virtud de los procedimientos de reducción que contemplaron estrategias enunciativas diversas en las líricas. Por esto mismo, la construcción del corpus admitió la presencia de informaciones y datos que se 
sistematizaron a partir de la problematización inicial y los objetivos de investigación que motivaron los intereses (Santander, 2011: 4).

El recorte del corpus derivó entonces de la selección de las distintas agrupaciones/bandas/artistas que sobresalieron (masiva o públicamente) en la escena cultural argentina post-dictatorial y que, del mismo modo, reflexionaron sobre las nociones de la libertad.

La elección refirió a los artistas del rock argentino que formaron sus agrupaciones a partir del año 1980 o iniciaron su etapa solista durante este período, y se destacaron por proponer una estética bailable, irónica y pop, que en distintas instancias reivindicaban la dimensión corporal y el erotismo o la sensualidad como algo tradicionalmente dejado de lado por la corriente principal del rock argentino.

Por consiguiente, se tomaron como referencia los siguientes exponentes: Andrés Calamaro, Fabiana Cantilo, Celeste Carballo, Charly García, Alejandro Lerner, Fito Páez y Maria Rosa Yorio; Don Cornelio y la Zona, Fricción, GIT, La Sobrecarga, La Portuaria, La Torre, Los Abuelos de la Nada, Los Enanitos Verdes, Los Encargados, Los Fabulosos Cadillacs, Los Pericos, Los Twist, Man Ray, Metrópoli, Soda Stereo, Sueter, Sumo, Virus y Viudas e Hijas de Roque Enroll.

El propósito de esta elección diversa se debió a la intención de abarcar los discursos líricos desde las distintas perspectivas del pop propuestas por el rock argentino. La amplitud y asimismo, el límite del análisis correspondieron a una intención de trabajo exhaustivo, más que de aproximación, puesto que se buscó encuadrar un análisis integral y sólido que evitara la reiteración.

En efecto, el trabajo postula un estudio concreto de las piezas discursivas a partir de la contextualización y de la aplicación de ciertas categorías analíticas que permitieron detectar las huellas subjetivas plasmadas en las líricas y aproximarse a las intencionalidades. La elección heterogénea implicó comprender que los relatos producidos resultaron suficientes en una medida no cuantitativa: se saturó la investigación cuando los argumentos de las líricas ingresaron en una instancia de redundancia y se confirmó la presencia de los núcleos importantes y problemáticos de los discursos que atraviesan las enunciaciones líricas.

\subsection{Objetivos}

A partir de las indagaciones en recorrido teórico, las referencias del estado del arte y el 
recorte del corpus, se establecieron los siguientes objetivos generales y específicos:

\section{a) Objetivo general}

- Identificar y analizar la construcción discursiva del ideario de libertad que tematizan las letras del rock argentino en torno a la transición democrática, desde junio de 1982 hasta julio de 1989.

\section{b) Objetivos específicos}

- Analizar la tematización de la libertad que presentan las letras del rock argentino del período 1982-1989, tomando en consideración las marcas y huellas de la subjetividad en el lenguaje.

- Analizar y describir el contexto de transición democrática que construyen las líricas seleccionadas en virtud de la tematización de la libertad.

- Analizar y describir las estrategias enunciativas que se articulan en las líricas seleccionadas.

- Estudiar diferentes fenómenos discursivos que se evidencian en las líricas seleccionadas como corpus.

\subsection{Hipótesis}

El discurso presente en las líricas del rock argentino del período mencionado se articula en relación con la conformación de un ideario democrático y la búsqueda de la libertad en este contexto. En función de ello, el abordaje de la libertad que tematizan las líricas seleccionadas como corpus se efectúa en un ámbito de discursividad social vinculado con un inicio de transición democrática y la situación de una sociedad en reconstrucción.

La construcción de la libertad en las líricas, entonces, es abordada como un capital en disputa que propone saberes, luchas y discusiones, y es problematizada de diversos modos: 1) se habla de liberación en relación con la retirada militar y la apertura de transición hacia la democracia; 2) se efectúan resguardos, defensas y conceptualizaciones para comprender el alcance de la libertad en la posdictadura; 3) se presentan articulaciones cotidianas $\mathrm{y}$ aspectos que postulan un abordaje lúdico $\mathrm{y}$ 
celebratorio de la vida; 4) se advierte una manifestación individual y escapista en un marco de convivencia democrática 5) y se atraviesa una instancia de tensión individual que resquebraja las comprensiones y las convivencias en democracia.

\subsection{Estructura capitular del trabajo}

La presente tesis se encuentra diagramada a partir de diez capítulos vertebradores que entrelazan justificaciones, conceptualizaciones, aspectos metodológicos y abordajes analíticos que dan cuenta de un trabajo integral desde una perspectiva discursiva. Por tanto, y como se advierte en estas líneas, el capítulo uno contiene la presentación de la tesis y expone la justificación del tema elegido para la investigación. Asimismo, precisa un estado de la cuestión y presenta el tema-problema las preguntas de investigación, la hipótesis, la fundamentación y la inclusión de los objetivos generales y específicos que acompañaron la actual investigación doctoral.

El segundo capítulo da cuenta del recorrido teórico y contiene, a partir de ello, una selección de seis categorías conceptuales que permiten comprender el vínculo entre los estudios del discurso como práctica social, los marcos enunciativos, la tematización de la libertad como referencia teórica, los diálogos en torno al concepto de transición democrática, las coordenadas conceptuales de la cultura del rock (y su relación con la cultura popular) y las instancias generacionales como espacio de disputa. Se tienen en cuenta las siguientes seis esferas teóricas: a) Discurso; b) Enunciación; c) Transición democrática; d) Cultura Rock; e) Libertad; y f) Jóvenes.

El tercer capítulo advierte la contextualización política y económica de la Argentina durante el período 1982-1989. Asimismo, también aprecia la situación de la cultura rock vernácula en dicha ubicación temporal. Esta división potencia la relación entre lo cultural y lo político, y sirve a los fines de manifestar las instancias sociales que atravesaron el período propuesto.

Posteriormente, el cuarto capítulo subraya el recorrido metodológico efectuado desde el marco de la discursividad y la teoría de la enunciación. Se señalan así las disposiciones constantes del trabajo, en torno a la conceptualización y la puesta en organización de los discursos; se destaca también la conformación de corpus analítico y la inclusión de categorías analíticas del estudio del discurso.

En el capítulo cinco se organizan las líricas del corpus que remiten a la transición democrática y precisamente al pasado dictatorial. De este modo, se articula un rechazo 
hacia el autoritarismo y la consiguiente reconfiguración de la libertad desde una clave de apertura democrática. Las perspectivas que se toman resultan trascendentales porque comprenden los cuadros dialógicos y discursivos que se activan y retroalimentan con el espacio social. La construcción discursiva de la libertad se trabaja entonces desde instancias diversas y se coloca como marco de reflexión y discusión en espacios sociales disímiles.

En el sexto capítulo se trabajan las instancias de defensa democrática que integran ciertas letras del corpus seleccionado. En este sentido, se tienen en cuenta que el retorno de la democracia a la Argentina produjo una instalación cultural de convivencia y debate político en el que las juventudes relacionadas con la cultura rock se ocupó de redefinir las discusiones acerca de la libertad.

El capítulo siete da cuenta de la temática de la diversión y la alegría que presentan las líricas analizadas en este apartado. Se advierte así una respuesta y una reacción contra el pasado represivo y su actualización en democracia. En función de ello, las letras proponen tácticas y estrategias enunciativas distintivas en torno a la situación de lo bailable y lo contracultural: se busca un tenor irónico y parodiado en el ámbito cotidiano; y se hace alarde de la corporalidad como lugar de dominio libertario.

En el octavo capítulo se presentan las líricas del corpus que tematizan una cotidianeidad mucho menos universal y de tono más individualista que, tras la particularidad festiva y celebratoria, proponen una cosmogonía tensionante y escapista.

El capítulo nueve permite establecer una continuación directa con el anterior, desde el rigor temático de la libertad, pero ofrece una complejización: comienzan a avalarse estilos y discursos líricos rupturistas en vínculo tensionante con una estética posmoderna y nihilista. Las líricas construidas para este capítulo manifiestan una fractura discursiva y las estrategias enunciativas se vinculan con modos más sarcásticos a partir de relatos fragmentarios.

Por último, el décimo capítulo oficia como espacio para subrayar las consideraciones finales y reunir así los comentarios parciales expresados en los capítulos previos. De este modo, el recorrido final se construye en virtud de un entrecruzamiento de situaciones interpretativas que admiten un muestreo que incluye una detención de la mirada, pero no una intención conclusiva o de cierre.

En virtud de ello, se invita a la lectura con la convicción y el deseo de provocar las mismas expectativas y las inquietudes con las que se inició esta investigación. En este sentido, también se pretende generar una empatía con la investigación que sintonice el 
entusiasmo que ha tenido la producción y la escritura en relación con el estudio del discurso y de la cultura rock en un marco de comunicación social. 


\section{Capítulo II}

\section{Marco teórico}

Este capítulo expone las articulaciones teóricas que permitieron investigar, analizar y entender el objeto de estudio desde el campo específico de la comunicación. Las categorías teórico-conceptuales se trabajaron a partir de un campo conceptual que atraviesa el estudio concreto de la investigación. Por esto mismo, se tienen en cuenta seis tramas claves para reflexionas sobre el marco teórico: discurso; enunciación; libertad; transición democrática, cultura rock y jóvenes.

Las esferas conceptuales mencionadas delimitan el actual marco teórico y permiten comprender el vínculo entre los estudios del discurso como práctica social, los marcos enunciativos, la tematización de la libertad como referencia teórica, las definiciones vinculadas con la transición democrática, las coordenadas conceptuales de la cultura del rock (y su relación con la cultura popular) y las instancias generacionales como espacio de disputa.

En efecto, la dimensión comunicativa se entiende como un proceso participativo de construcción y reconstrucción de sentidos que admite la continua interpretación y reinterpretación de intenciones explícitas y no explícitas en un marco enunciativo (Valentino y Fino, 2015: 9). La comunicación no es concebida como un proceso de transmisión de datos e informaciones entre dos polos, sino como trayecto interactivo de construcción-reconstrucción de sentidos que incluye una continua interpretaciónreinterpretación de intenciones explícitas e implícitas. La comunicación responde a una puesta en común de las experiencias comunes mediante enunciados, con el fin de establecer acuerdos "intersubjetivos" sobre el "mundo de todos", el conjunto de mapas que conforman la cartografía que por convenciones culturales denominamos "realidad" (Valentino y Fino, 2015: 9).

En función de ello, las letras proponen un acto de comunicación que se caracteriza por establecer normas de vida común y construir una visión común del mundo desde el discurso producido. De esta manera, el lenguaje provoca el sentido y genera el lazo con una situación de discursividad.

El acto de pensar de este modo la investigación admite un intento de rescate desde una perspectiva crítica que se encuentra presente desde los inicios del campo de estudio en 
comunicación latinoamericanos y que permite pensar el presente de la sociedad desde la intervención analítica en comunicación. Esto mismo contribuye para actuar sobre las problemáticas de la constitución de la subjetividad en el proceso de la vida sociocultural. En efecto, complejiza los modos en los que las subjetividades se comunican, producen y narran desde el lazo social, "como manifestación de la necesidad de representación propia de la humana condición” (Fasano; Giménez; Ruiu, 2002: 3).

\subsection{Discurso}

El concepto discurso propone una dimensión teórica y polisémica que se construye a partir de perspectivas distintivas sobre el lenguaje. El discurso puede comprenderse como un equivalente a la "parole" o a la utilización individual del lenguaje, enunciada por el lingüista Ferdinand de Saussure. También puede postularse como una unidad lingüística, en términos de la gramática textual; como un enunciado de dimensión interactiva, de acuerdo con lo abordado por la pragmática; como una sucesión de frases condicionadas por un conjunto de reglas; o como el uso de la lengua en un contexto en particular.

El discurso se vincula con las condiciones de producción y de interpretación, los elementos de la situación enunciativa y el proceso textual. Como cualquier otra práctica social, se comporta de un modo complejo y heterogéneo, y desde distintos niveles de organización. En este sentido, el discurso es comprendido como una práctica lingüística y social que implica una relación dialéctica entre un suceso discursivo particular y las situaciones, instituciones y estructuras sociales que lo configuran.

Por tanto, el discurso es un texto contextualizado que tiene a la enunciación como contexto productor del discurso (Parret, 1987). El concepto de discurso designa un nivel de análisis de los textos que los contempla y lo presenta como un escenario que permite operar sobre el funcionamiento de la lengua. Es un sistema de significación que oscila entre lo explícito y lo implícito, una combinación entre los modos de decir de significar y un conjunto de posibles significados que circulan en sociedad (Londoño Zapata, 2012: $100)$.

El estudio del discurso permite analizar el lenguaje sin aislarlo de su contexto comunicativo y cultural; es decir, sin apartar las características formales de su función de mensaje y del sentido que la vehiculiza. En este aspecto, se comparte que el discurso es un objeto de investigación complejo que requiere aproximaciones también complejas 
que acompañen la experiencia del análisis $\mathrm{y}$, sobre todo, que valoren el protagonismo del contexto (Londoño Zapata, 2012: 193).

A partir del uso del lenguaje, el discurso se vincula dialécticamente con lo social. Así, el contexto es entendido inicialmente como la estructura de aquellas propiedades de la situación social que son relevantes para la producción y la comprensión de los discursos, y a su vez, se configura como un elemento constituido por el discurso.

Por ello mismo, la comprensión del discurso como práctica social, permite entenderlo desde una relación dialéctica entre el discurso y el contexto. En suma, forma parte de la vida de las personas $\mathrm{y}$, al mismo tiempo, es un instrumento que constituye las prácticas sociales. El discurso, entonces, se considera a partir de su relación con el lenguaje en uso en distintos contextos relacionales y comunicacionales. La concepción discursiva no se vincula con la actividad individual sino como una práctica social, un modo de acción que persigue propósitos y es comprendido como la asociación de un texto y su contexto.

\subsubsection{El discurso como práctica social}

Continuando con lo antedicho, el discurso es un fenómeno práctico, social y cultural que refiere a sus condiciones sociales de producción y a su marco cultural, ideológico, institucional e histórico-coyuntural. En función de ello, los discursos son prácticas sociales en las que los hablantes ponen en juego, de maneras explícitas e implícitas, sus propias subjetividades (valoraciones, concepciones del mundo, ideologías).

La definición que comprende al discurso como práctica social permite vincularlo con instancias ideológicas y significativas que construyen estructuras y actividades que se dan en la sociedad:

Se puede aplicar -y se está aplicando- a ámbitos como la sanidad, la divulgación del saber, la administración de la justicia, los medios de comunicación de masas, las relaciones laborales, la publicidad, la traducción, la enseñanza, es decir allá donde se dan relaciones interpersonales a través del uso de la palabra y personas con características diferentes(por edad, sexo, lengua, nivel de conocimiento, origen de clase, origen étnico, profesión, estatus, etc.) se ponen en contacto (hombres y mujeres, enseñantes y aprendices, médicos y pacientes, especialistas y legos, administradores y usuarios de la administración, anunciantes y consumidores, etc.) (Calsamiglia y Tusón, 1999: 26). 
La noción de discurso implica una relación dialéctica entre un suceso discursivo particular y las situaciones, instituciones y estructuras sociales que lo configuran. De este modo, lo discursivo forma parte de las prácticas cotidianas y asimismo, es un instrumento que constituye las prácticas sociales. El empleo de determinados términos, construcciones discursivas y modos de referencia a otros está ligada a una ideología, una visión del mundo, metas y finalidades concretas (Del Manzo y Martínez, 2014). Estas opciones permiten desplegar estrategias discursivas para lograr diversos fines de persuasión o alcance.

El discurso, como práctica social, se vincula con el marco social de producción y las condiciones institucionales, ideológicas cultural e histórico-coyuntural en la que se conforma. En este sentido, se observan las implicancias discursivas de las relaciones de poder y las consolidaciones hegemónicas que se advierten en sociedad, puesto que instalan marcos ideológico, históricos y formas de acción social. El discurso es, por consiguiente, una situación de enunciación, institución, estructural social, condiciones de producción, esferas de la vida social o, simplemente, contexto (Arnoux, 2006: 13). Se pueden señalar entonces, tres áreas en torno al vínculo entre discurso y sociedad: la primera se articula con las estructuras sociales y la producción, la construcción y la comprensión del discurso; la segunda señala que el discurso construye, constituye, cambia, define y contribuye a las estructuras sociales; y la tercera "interfaz" entre discurso y sociedad confirma que las estructuras del discurso abordan, denotan o representan partes de la sociedad (Van Dijk, 1999). Por esto mismo, se reitera que el discurso revela una vinculación intrínseca con el poder y con aquello que traduce disputas, invectivas, luchas o situaciones de dominación y fragilidad.

En función de ello, las letras de rock se instituyen como discursos que devienen en determinadas prácticas sociales y proponen producciones sociales de sentido que formulan representaciones del mundo; exponen lugares comunes, conversaciones triviales, espacios dogmáticos y discutibles de la denominada opinión pública; y también plantean eslóganes o especulaciones estéticas, filosóficas y políticas de los acontecimientos.

En efecto, las letras del rock se entienden como un acto de comunicación que se caracteriza por establecer normas de vida común y construir una visión común del mundo desde su contexto histórico social de enunciación y a partir de la situación de comunicación de la que se articula. Las letras presentan una polisemia de sentidos que 
se oponen, resisten y se muestran, en la mayoría de los casos, en contra del abuso de poder, la dominación, la opresión, la desigualdad y la injusticia. Así se desarrollan a partir de sucesiones de imágenes fragmentarias que se yuxtaponen y que, en otros momentos, se presentan como crónicas que tematizan historias de diferente índole.

Las letras de rock argentino forman parte de una discursividad plausible de analizar en relación con la constitución de los jóvenes y la instauración de márgenes desde distintas tramas culturales. Se trata, ciertamente, de una forma de comunicación que construye discursos de cotidianeidades, virtudes, sentidos y vacilaciones en tiempos agitados. En consecuencia, el discurso propuesto por las letras de rock argentino se completa a partir de un conjunto complejo de actos lingüísticos, sonoros y visuales que se construyen en un ámbito de práctica social de un modo dialéctico y dialógico. Se advierte entonces, que las manifestaciones de la cultura rock (enunciaciones que son consumadas desde la cultura popular) se nutren de una gran corriente discursiva que resignifica sus prácticas y transforma, desde ya, las propias condiciones de producción.

\subsubsection{La letra de rock y el discurso social}

Las letras de las canciones de rock presentan un conjunto complejo de operaciones discursivas que activan pensamientos aleatorios, centrífugos y marginales que se enfrentan a la aceptabilidad, las modalidades tolerables y las jerarquías impuestas por los discursos sociales. Justamente, los discursos sociales construyen el escenario social, lo objetivan y comunican representaciones. Estos discursos sociales contienen regularidades de la vida en sociedad en general y se encuentran atravesados por tramas y relatos de un contexto cultural e histórico particular. En términos de Marc Angenot, el discurso social se articula a partir de todo lo que se ve, se escribe y se dice en un estado determinado de la sociedad (2010: 21).

A partir de esta última lectura, también es posible entender que el discurso social corresponde a circulaciones y formaciones discursivas ya dichas, que funcionan a partir de lo presupuesto, "lo preconstruido, lo cristalizado, lo petrificado, lo informe de la costumbre, lo no dicho, lo no pensado, lo que inmoviliza; una pluralidad fragmentaria, el ruido del mundo que se va a convertir en materia textual” (Robin, 1994: 272).

Las letras, aún desde su diálogo con la industria cultural y el comercio, colocan en tensión los instrumentos de control social y generan intersticios en los que se filtran sus propias temáticas y repertorios. Es decir que las líricas producen un escenario de debate 
en torno a las instancias hegemónicas de los discursos sociales. Así, se colocan en crisis intereses estructurales, tradiciones y posiciones adquiridas.

La articulación discursiva presente en las canciones se construye lógicamente en un ámbito de práctica social. Al respecto, las letras activan repertorios propios del discurso social que se crean a partir de estrategias léxicas y que ponen en crisis la denominada realidad social de época y la naturaleza discursiva de este proceso de construcción.

Ante esto, Angenot remarca el componente ideológico que acopla las ideas y los modos de hablar del marco social correspondiente, así como los rasgos específicos de los enunciados exteriorizan marcas de funciones, efectos y condiciones de producción que se reconocen en la organización textual y en las proposiciones lingüísticas: "Hablar de discurso social será describir un objeto compuesto, formado por una serie de subconjuntos interactivos, de migrantes elementos metafóricos, donde operan tendencias hegemónicas y leyes tácitas" (2010: 25).

Siguiendo la línea teórica de Mijaíl Bajtín, Angenot entiende al discurso como un hecho situado históricamente y particularizado según las evaluaciones sociales. De esta manera, los discursos sociales dan cuenta de un complejo entramado de voces que manifiestan lo enunciable y lo decible un momento concreto de la historia. La aceptabilidad, en este caso, juega un papel preponderante porque expone aspectos legitimados de las producciones discursivas de una sociedad y supone la existencia de una situación hegemónica, reguladora y vinculada con "los sistemas de dominación política y explotación económica que caracterizan una formación social” (2010: 29).

La observación de las instancias hegemónicas en los discursos permite examinar las funciones propias de los discursos en la reproducción social. La hegemonía produce lo social como discurso e impone dogmas, fetiches y tabúes. Igualmente, implica un control social que presenta un "canon de reglas" e imposiciones legitimadoras, inscriptas bajo una asociación de poderes, restricciones y medios de exclusión que remiten a arbitrariedades formales y temáticas. En consecuencia, la hegemonía articula las reglas de lo decible así como conjuga los dispositivos de censura que bloquen lo indecible. La hegemonía opera a partir de un campo de temáticas, de saberes aceptables y parámetros retóricos, narrativos o argumentativos (Angenot, 2010: 67).

Por esto mismo, resulta conveniente destacar los elementos que componen las instancias hegemónicas y resaltan los modos de abordaje que pueden emplearse para comprender los comportamientos de los discursos sociales (Angenot, 2010: 39): 
1) la lengua legítima es inseparable de los saberes de protocolo, los usos legitimadores y la aceptabilidad de los enunciadores que articulan el discurso;

2) tópica y gnoseología: la Tópica se relaciona con la producción de lo opinable que sostiene la dinámica de los enunciadores de todo tipo. Se engloban así implícitos y presupuestos propios de una determinada época que, a partir de la denominada doxa, vehiculizan probabilidades y creencias. La Gnoseología, por su parte, corresponde a un conjunto de reglas que determinan la función cognitiva de los discursos y se enlaza teóricamente con las llamadas "estructuras mentales" que aplican en cada contexto o época.

3) los fetiches y tabúes son producidos por el discurso social y se erigen como objetos temáticos, abordados de la retórica, que tientan a los transgresores y los iconoclastas.

4) el egocentrismo y el etnocentrismo integran lo hegemónico porque advierten la presencia de un Yo y un Nosotros que divide, selecciona o aparta de acuerdo a la aceptabilidad y legitimidad discursiva.

5) las temáticas y las visiones del mundo integran lo hegemónico y se relacionan tanto con las instituciones isotópicas como con las situaciones temáticas que se nombran, se valorizan, se describen o comentan en un contexto determinado.

6) el phatos refiere a los "temperamentos" de una época y/o los "estados de ánimo" dominantes en un contexto particular.

7) el sistema topológico implica una división de discursos específicos, reagrupados en campos o regiones que ubican las tópicas comunes. Así, la hegemonía emplea una convergencia de tareas discursivas migra y adapta las formas del lenguaje.

La letra de rock se configura entonces, como un discurso que tanto de modo categórico como ambiguo refiere a aspectos decibles y no decibles en un estado particular de la discursividad social. En consonancia, se encuentran atravesadas por discursividades integradas por sistemas genéricos, repertorios tópicos y/o reglas de encadenamiento de enunciados que aseguran el trabajo discursivo y organizan e instituyen lo narrable u opinable en una sociedad correspondiente.

Las líricas vehiculizan las expectativas de la sociedad, con sus nerviosismos, sus contrariedades y sus compromisos de época. Actúan, de este modo, como canales expresivos que enuncian experiencias sustanciales de comunicación y representan malestares, problemáticas humanas y quehaceres de una determinada realidad social. En 
este aspecto, el carácter comunicativo de las letras consiste en compartir significados y formar unidades sociales que tienen en común valores, reglas de convivencia, actuación y modos de vida.

\subsubsection{Las letras de rock como género discursivo}

La lírica de rock argentino posee un discurso de expresión artística-cultural que rescata identidades o épocas que manifiestan (y proponen) posturas políticas e ideológicas. La identificación de la noción de género discursivo resulta necesaria porque contribuye a develar las circunstancias enunciativas en las que circula el discurso, como así también cómo se materializa la circulación discursiva en productos textuales concretos.

La relevancia del género es central porque configura no sólo las finalidades u objetivos de la instancia enunciativa sino que además visibiliza la materialización. Del mismo modo, permite relevar cómo a partir de la práctica discursiva los sujetos se vinculan con el mundo, la historia y la ideología en términos enunciativos. En todo ámbito de la práctica social, se postula una regulación de los intercambios $\mathrm{y}$, consecuentemente, una instauración de articulaciones discursivas y enunciativas.

De acuerdo con la caracterización de los géneros discursivos propuestos por Bajtín (1982), en todo discurso pueden identificarse rasgos temáticos, compositivos y estilísticos. Las letras de rock son un género discursivo porque construyen a partir de enunciados concretos y singulares que se encuentran atravesados por condiciones de producción determinadas. Así, están articuladas por tipos temáticos, composiciones y estilísticos de enunciados de enunciados concretos y relativamente estables.

Los enunciados que integran las letras se articulan en virtud de su contenido (temático) y su estilo verbal, es decir, por la elección de los recursos léxicos, fraseológicos y gramaticales de la lengua, y, sobre todo, por su compasión o estructuración. Tanto el contenido temático, el estilo y la composición se encuentra vinculados en la totalidad del enunciado y se configuran de acuerdo al escenario de comunicación establecido. En términos de Bajtín, cada enunciado separado es, por supuesto, individual, "pero cada esfera del uso de la lengua elabora sus tipos relativamente estables de enunciados, a los que denominamos géneros discursivos" (1982: 185).

Las letras de canciones, en este caso de rock argentino, constituyen un género discursivo con coordenadas propias y rasgos distintivos. Las letras funcionan como 
soporte genérico en el que se ponen en juego relaciones sociales a partir del lenguaje como material, demarcando así una ideología como valoración del mundo.

En este sentido, se plantea una instancia enunciativa en la que se identifican los participantes, los sujetos interpelados, los propósitos que motorizan la enunciación y la construcción de un relato. La comprensión de su instancia genérica permite abordar un análisis discursivo que articula lo puramente textual con un contexto a partir ciertos indicadores que sitúan la instancia comunicativa.

La ordenación de este ámbito de la práctica social con la actividad discursiva resulta central, aún más cuando se deben reconocer las situacionales, diversas y extensas interactuaciones. El intento de reconocimiento y clasificación de dichas regularidades discursivas permite comprender una necesaria multiplicidad de recursos que utilizan los sujetos para vincularse comunicativamente, conservando una estabilidad que permita recurrir a ellas y reconocerlas.

La propuesta que Bajtín ofrece una forma de codificación social, cultural e institucional. De esta manera, la riqueza y diversidad de los géneros discursivos resulta inmensa porque advierte inagotables posibilidades de "repertorios", organizados en un universo social y colectivo.

Las letras de canciones, en tanto género discursivo, se presentan como un "lugar social" para el analista y permiten posicionar así un campo discursivo que permite organizar la perspectiva analítica. Por esto mismo, Dominique Maingueneau remarca que en todos los casos se debe poner en evidencia el carácter central de la noción de género discursivo, puesto que "a título de 'institución discursiva' desbarata toda exterioridad simple entre 'texto' y 'contexto'. El dispositivo enunciativo corresponde a la vez a lo verbal y a lo institucional” (Maingueneau, 1999: 21).

Maingueneau se ocupa de la noción de género desde una perspectiva que supera la noción sociológica. Es decir que su posicionamiento describe las condiciones sociales y también aborda la escenificación: la escena que se está construyendo a través de la propia palabra. A estas instancias, el discurso, en tanto género discursivo, es siempre al mismo tiempo un cuadro y un proceso. Por lo tanto, el autor distingue entre una escena englobante, que le otorga un estatuto pragmático al texto, y una escena genérica que es definida por los géneros de discurso particulares. Estas dos escenas definen el marco escénico del texto, dentro del cual el texto se manifiesta como pragmáticamente adecuado: "En efecto, cada género de discurso implica una escena específica: roles para sus participantes, circunstancias (en especial un modo de inscripción en el espacio y en 
el tiempo), un soporte material, un modo de circulación, una finalidad, etc." (Charaudeau y Maingueneau, 2005:222).

Patrick Charaudeau, por su parte, entiende al género como un contrato global del ámbito de la comunicación que presenta las siguientes variantes: las circunstancias situacionales; la organización discursiva y las restricciones específicas emanadas de las circunstancias situacionales; las formas textuales que dan cuenta de las regularidades de la configuración textual (2004). En este aspecto, se representa una conceptualización de los géneros como construcciones históricas y consecuencias de convenciones implícitas que posibilitan la escena comunicacional.

En suma, el autor plantea la idea de "género situacional" y de niveles que, por un lado, permiten reunir textos en torno a características del ámbito de comunicación (situacionales); por otro, deben ser considerados como el conjunto de procedimientos exigidos por las instrucciones situacionales para especificar la organización discursiva (restricciones discursivas); y finalmente presentan ocurrencias formales volátiles para tipificar definitivamente un texto, aún con indicios (configuración textual). La definición de los géneros del discurso se articula y se interrelaciona a partir de la participación de estos tres niveles.

\subsubsection{Las letras de rock en un marco dialógico}

De acuerdo con la interpretación teórica, se advierte que el género discursivo entraña relaciones dialógicas y polifónicas. Es decir, que se plantea desde una noción de interacción discursiva, tomando relevancia desde la construcción, la estructuración y la producción discursiva. El género discursivo entraña relaciones polifónicas y dialógicas porque está atravesado por prácticas sociales, cuya construcción discursiva es colectiva, histórica, política, dinámica, dialéctica, temporal y situacional.

En este escenario los distintos discursos confluyen y dialogan desde diferentes posturas y configuran tanto la práctica discursiva como el género discursivo. El enunciado, por lo tanto, se encuentra relacionado con los eslabones anteriores y con los eslabones posteriores de la comunicación discursiva: "El enunciado se construye desde el principio tomando en cuenta las posibles reacciones de respuesta para las cuales se construye el enunciado (...) Un signo importante (constitutivo) del enunciado es su orientación hacia alguien, su propiedad de estar destinado" (Bajtín, 1979: 285). 
Como se mencionó, Bajtín piensa una teoría del lenguaje desde una perspectiva dialógica y polifónica que advierte una comprensión discursiva desde la interacción y la participación de enunciadores contestatarios. Se reconoce así una posibilidad discursiva de contribuir a la configuración de una trama ideológica y el debate en torno a las relaciones de poder en términos del lenguaje.

Las relaciones dialógicas son relaciones (de sentido) entre toda clase de enunciados en la comunicación discursiva Pero las relaciones dialógicas no coinciden en absoluto con las relaciones que se establecen entre las réplicas de un diálogo real, por ser mucho más abarcadoras heterogéneas y complejas. Dos enunciados alejados en el tiempo y en el espacio y que no saben nada el uno del otro, si los confrontamos entre su sentido y si manifiestan en esta confrontación alguna convergencia de sentidos (...) revelan una relación dialógica (...) Así, pues, las relaciones dialógicas son mucho más amplias que el discurso dialogado en sentido estricto (Bajtín, 1997: 309-316-317).

Las letras de rock proponen una poética de tensión y se traban en lucha con manifestaciones enlazadas en la discursividad social. Admiten una especificidad característica que construye escenarios y destaca intencionalidades. A partir de ello, se desarrollan narrativas y tópicos, nociones de resistencia, habilidades cuestionadoras y/o adaptaciones que se vinculan con reconfiguraciones sociales. La puesta en circulación de estos relatos contiene representaciones y enunciaciones que concentran situaciones comunicativas e instancias de disputa.

Teniendo en cuenta este planteamiento, este trabajo asume el objetivo de estudiar las letras a fin de comprender su dimensión como espacio de interacción social y construcción discursiva. A partir de esta concepción, resulta importante la figura del interlocutor y el modo en el que se realiza la orientación del correspondiente enunciado. El carácter dirigido del enunciado se postula como un rasgo constitutivo que le da existencia al enunciado. Las distintas maneras de poner en juego este carácter funcionan como particularidades constitutivas que comprueban la especificidad de los géneros discursivos.

En otras palabras, el enunciado debe ser analizado como respuesta a los enunciados anteriores de una esfera dada: los refuta, los confirma, los completa, se basa en ellos, los supone conocidos, los toma en cuenta de alguna manera. Por consiguiente, ocupa una 
posición preponderante en la esfera dada de la comunicación discursiva y cobra relevancia a partir de su rasgo dialógico: "Todo enunciado vivo. No puede dejar de tocar miles de hilos dialógicos vivos, tejidos alrededor del objeto de ese enunciado por la conciencia ideológicos-social. Porque tal enunciado surge del enunciado como su réplica y continuación y no puede abordar el objeto proviniendo de ninguna otra parte" (Bajtín, 1934: 94).

\subsubsection{Música y versos integrados}

Las letras de las canciones de rock proponen una instancia poética y actúan también como diálogos teatrales o cinematográficos que se hacen voz e impactan en el quehacer del lector-espectador-escucha. Abordadas desde la figuración abstracta y la alegoría o desde el realismo, las líricas están atravesadas por huellas subjetivas que interrogan lo dado como "real".

Dichas letras contienen versos integrados a una música y presentan un discurso libre de métricas y rasgos de poesía pura. Se advierten, no obstante, rasgos temáticos, compositivos y estilísticos característicos que determinan núcleos semánticos y construcciones en torno a mundos posibles (Conde, 2003: 16).

Así, la dimensión lírica expone distintos rasgos temáticos, estilísticos y, sobre todo, retóricos que admiten visiones y paradigmas en los relatos. La lírica como concepto contiene una materialidad que permite establecer formaciones discursivas constituidas por un número circunscrito de enunciados. Por ello mismo, es entendida como un acto de discurso que resulta fundamental para comprender el género discursivo en el que se enmarca enunciativamente.

En términos de Bárbara Ferris Graves y Donald McBain, la voz lírica de la cultura rock floreció hacia la década del 60 a partir del intento obstinado de los hombres y las mujeres de penetrar en el sentido de la existencia "en función de la relación de voces de la calle, voces que entrelazan los sonidos del presente con las viejas cuestiones de la relación del hombre con su amada, su sociedad y con el cosmos" (1972: 59).

La poética de esta ficción plantea nociones de verdad y mentira que se mantienen en una línea fronteriza que genera percepciones y escenarios propuestos por el sujeto hablante de cada discurso. Los aspectos de ficción, en este caso, están sometidos al devenir histórico, puesto que la consideración depende de los modelos culturales y de los modelos de mundo. Por ende, los factores ideológicos pretenden conservar mundos 
y/o rechazar situaciones de horror, opresión y sometimiento: "La ficción es un fenómeno dinámico y condicionado por la historia y la cultura" (Pavel, 1983: 179). La insumisión del género de letra de rock argentino, en términos de $p o p$, advierte un rechazo a la autoridad o al conservadurismo y se expresa más que nada por su sentido de la formula: un estribillo intenso y remarcado, una consigna sucinta y recordable, e incluso un título representativo. En estos términos, Claude Chastagner remarca que el rock deslumbra cuando presenta textos concisos y permite alusiones líricas que, sobre todo, evitan el discurso pedagógico y la definición sesuda:

El rock brilla (...) cuando prefiere el grito y el aullido a la demostración, la emoción a la reflexión, la sugerencia a la explicación. El rock es, ante todo un arte del eslogan que, simplista y superficial a primera vista, condensa un máximo de sentido, de impacto emocional y simbólico en una forma exigua y excitante (...) Bajo la forma minimalista del eslogan, la emoción constituye una apropiación de la palabra, una réplica, un diálogo en sentido bajtiniano, opuesto a la concepción foucaultiana de discurso desencarnado, dominador y único (Chastagner, 2013: 59).

Siguiendo a Chastagner, las líricas de rock funcionan como cantos de amor y de sexo (llamado a la revuelta), diatribas encendidas, eslóganes militantes, introspecciones, ensoñaciones románticas, exploraciones del mundo interior, ironías y/o subversiones (2013: 74). Estos componentes discursivos integran la cultura del rock y nutren las complejidades de las diferentes generaciones y sus imaginarios.

Las líricas de rock son poseedoras de artificios retóricos y características propias de la función poética que consideran valoraciones éticas y desplazamientos literarios que abordan problemáticas e interrogantes sociales. Ante esto, el análisis discursivo de las letras permite indagar la reciprocidad existente entre las líricas y el contexto social, cultural, político y económico en el que fueron elaboradas.

En ciertos aspectos, las letras de rock argentino presentan una situación literaria que exponen aspectos heterogéneos que refieren a su función ética y poética en torno a la sociedad de masas. Así se caracterizan manifestaciones de carácter literario que vehiculizan aspectos éticos, intereses, idearios, usos, abusos y/ o enunciaciones que dominan en los contextos determinados. Estos discursos sociales, de tenor poético, alegórico o narrativo se manifiestan generalmente en ciertas figuras retóricas de nivel 
semántico que advierten imágenes, metáforas, contrariedades, recreaciones de palabras, entendimientos e incoherencias/paradojas.

El lirismo permite entonces, activar una estética directa, sutil o enigmática, acentuando así diferentes modos enunciativos:

Para algunos, las mejores letras son las que se valen por sí mismas en un papel, como un poema. Esto no es verdad en todos los casos y el rock se ha ocupado de poner esta noción en tela de juicio: letras de Bob Dylan, Leonard Cohen o Randy Newman, por ejemplo, pueden leerse con placer al margen de la música, pero una letra efectiva como "Tutti Frutti" (Little Richard) no pasaría dicha prueba. Ocurre que en buena parte del rock lo sensorial impera sobre lo racional (Berti, 2009: 9).

El ámbito de la rima propone una unicidad de sonido y sentidos exactos con el objeto de generar impugnaciones e ingenios. La canción realiza un abordaje sobre el uso del lenguaje:

Dirige nuestra atención sobre los juegos de palabras y la rima, sobre la forma en que este fragmento de espectáculo comercial fue elaborado poéticamente, por medio de repeticiones, contrastes, cambios de ritmo verbales (Frith, 2014: 307) (...) Las palabras son utilizadas como aforismos (otra manera de convertir palabras ordinarias en especiales, de destacarlas); o, en un proceso inverso que tiene el mismo efecto, frases comunes que perdieron su poder metafórico son tomadas seriamente y de este modo, re-significadas. Pero no se trata solamente de una política de la lengua. El "lenguaje cotidiano" también representa un tipo de conocimiento acumulado, una forma compartida de ser (y una forma compartida de ser a la que se le niegan derechos políticos, culturales y humanos) (Frith, 2014: 308).

En este sentido, el lenguaje de las canciones representa un aspecto importante de las reglas del género letra de rock: el empleo de un coloquialismo con léxico llano, gráfico, inmediato y concreto, y la exposición de un tono informal, comprensible y resumido en su estribillo (con mínimas recurrencias metafóricas). De este modo, la canción pop, en clave cultura rock, también explora relaciones entre hablas y manifestaciones distintivas: "Esto suele significar desafiar las jerarquías lingüísticas, subvertir el modo en que se usan las palabras para dominar: 'los textos de las canciones', como señala 
Roland Barthes, "proporcionan una marco para una conducta verbal permisiva" (Frith, 2014: 299).

Michael Gray, en su estudio sobre la poética del músico Bob Dylan, sostiene que aunque las letras de rock están hechas para ser cantadas, contienen sin embargo una riqueza poética y una carga de sentido en la estructura y la textura verbal. Este autor no se ocupa de la interpretación (que excede el análisis discursivo de la poética), sino se preocupa por el carácter indirecto del lenguaje en las estrofas, por la densidad de las alusiones y los juegos de palabras y por la identidad de discurso de rock que proponen (1981: 143).

\subsubsection{En torno a la dimensión retórica}

La estrategia retórica presente en las líricas de rock tiene un carácter performativo y parte de la capacidad del lenguaje para producir discursos persuasivos y, asimismo, provocar una relación con el contexto sociocultural determinado. En este sentido, el discurso de las líricas está construido por discursos sociales, caracterizados por aspectos retóricos que articulan alianzas, orientan pensamientos, aplacan emociones y/o guían acciones de seducción y excitación (Perelman, 2008).

La operación retórica se vincula con una formación de estereotipos que instauran posicionamientos, integrados a discusiones o perspectivas del marco histórico que las convoca. Estos procedimientos persuasivos y vinculantes con el contexto resultan relevantes porque atraviesan nociones ideológicas enlazadas con estadios o estructuras que atañen a la existencia de los jóvenes en sociedad.

La estrategia retórica sobresale en la discursividad social porque hace posible la consolidación de una trama comunicativa constituida por diálogos y contrastes de opiniones en un ámbito masivo. La lírica de rock, en este aspecto, acentúa su perspectiva retórica porque se articula en relación a la pluralidad de voces y dirige sus discursos a una comunidad de oyentes-lectores-espectadores:

La comunicación retórica en sociedad está asociada lo que denomino cenestesia comunicativa, que es la conciencia que quien pronuncia el discurso tiene del espacio comunicativo que el propio discurso crea y ocupa, en quién puede influir, a quién puede agradar, a quién puede disgustar, a qué sentimientos o convicciones puede afectar, etc. (...) Es entendido así el discurso como una 
prolongación de las intenciones y de los intereses comunicativos de quien lo pronuncia (Albaladejo, 2009: 44).

La operación retórica permite advertir un empleo de figuras retóricas que resulta interesante a partir de la combinación con rasgos temáticos, compositivos y estilísticos en un contexto determinado. La constitución retórica amplía las instancias comunicativas (desde un género discursivo particularizado en lírica de rock) que centraliza una situación persuasiva y contextual. En consecuencia, juega un rol primordial porque, como sintetiza Claude Chastagner, la rebelión del rock es ante todo de orden textual y las palabras, mediadas por estrategias retóricas ocupan un lugar muy importante en la cultura rock (2013: 53).

Sobre este punto, Serge Denisoff le atribuye dos modalidades de acción a las canciones de rock. Por una parte, la función movilizadora que facilita la participación y que se vincula directamente con las canciones orientadas al compromiso político y el movimiento colectivo. Por otro lado, la función retórica que brinda un acceso persuasivo y de articulación de opiniones en los oyentes de canciones o lectores de letras de rock (1972: 120).

Retomando esta perspectiva, Chastagner señala que las canciones de rock contribuyen a modestas, pero tangibles transformaciones, minúsculas tomas de conciencia, a una evolución de las mentalidades, a la emergencia de un nuevo estado de ánimo. Desde una revisión histórica en clave de cultura rock, las canciones plantean una estrategia retórica que permite estudiar la época y la contemporaneidad de otra manera (2013: 56).

De acuerdo con Simon Frith, las letras son una forma de retórica que debe tratarse en términos de una relación persuasiva y contextual: "Una canción no existe para transmitir el sentido de las palabras; más bien, las palabras existen para transmitir el sentido de las canciones (...) Es decir que las canciones pop funcionan a partir del lenguaje hablado, $\mathrm{u}$ operan sobre él" (2014: 295). Siguiendo con esta línea, es posible señalar que las canciones pop no suelen ubicarse como enunciados generales sobre postulados sociológicos o psicológicos, sino como ejemplos de una retórica estratégica que depende de los modos de articulación, el contenido verbal, el tipo de lenguaje utilizado y el significado simbólico. 


\subsection{Enunciación}

El análisis del discurso actúa como un instrumento que permite entender las prácticas discursivas que se producen en las distintas esferas de la vida en las que el uso de la oralidad y la escritura forma parte de las actividades que en ellas se desarrollan. El estudio del discurso permite rastrear los rasgos de subjetividad que atraviesas a los hablantes y advertir así las valoraciones, concepciones del mundo y/o marcos ideológicos que se presentan.

Por esta razón, el análisis discursivo habilita la posibilidad de prosperar, reflexiva y sistemáticamente, una producción de sentido en torno a los actos de comunicación que definen y establecen nuevos límites, espacios, contactos y síntesis. El intento de rescate desde una perspectiva crítica se encuentra presente desde los inicios del campo de estudio en comunicación latinoamericanos y posibilita un posicionamiento social desde la intervención analítica en comunicación.

Continuando esta línea, el análisis discursivo tiene por objeto dar cuenta del funcionamiento de los fenómenos lingüísticos en su uso y de los que estos evidencian en cuanto a la forma cómo los individuos que viven en sociedad construyen el sentido social (Charaudeau, 2009: 122). Esto mismo contribuye a actuar sobre las problemáticas de la constitución de la subjetividad en el proceso de la vida socio-cultural y atraviesa las complejidades de los modos en los que las subjetividades se comunican, producen y narran desde el espacio social.

En el caso del marco temporal planteado, los tópicos que se abordan se vinculan con una discursividad que tematiza la libertad y dan cuenta de las prácticas de los jóvenes de la generación del 80 (elementos que destacan situaciones comunicativas o contextuales de época). No obstante ello, cabe señalar que la propuesta no se exhibe de un modo acabado o cerrado, sino que se postula un intento de sistematización de información en un procedimiento analítico posible que admite una reflexión la compleja naturaleza de la producción discursiva. Al respecto, el estudio de las letras implica dar cuenta de los aspectos esenciales que implican la producción discursiva, la presencia de los contextos y los sentidos sociales que circulan en un sistema de coordenadas espacio/tiempo específico.

Las marcas o las huellas presentes y aprehendidas en un texto circulan como vehículos de subjetividad que crean mundos propios. La existencia de ciertas marcas, índices y/o mecanismos propios de cada discurso (deícticos, modalidades o las presencias 
polifónicas, por citar tres categorías importantes), permiten observar las configuraciones que se tienen sobre el entorno que envuelve a los seres hablantes.

\subsubsection{La teoría de la enunciación}

El análisis del discurso toma de la teoría de la enunciación la posibilidad de desarrollar un estudio que excede la problemática sintáctica y léxica. Si bien la enunciación no es un dominio fácil de aprehender y de definir, es posible señalar, junto a Juean Dubois, que es la aparición del sujeto hablante con respecto a su enunciado (1972: 100). A raíz de ello, la teoría de la enunciación se desarrolló profundamente a partir de los trabajos de Emile Benveniste y las permanencias analítico-teóricas de Oswald Ducrot (1986) y Kerbrat-Orecchioni (1983, 1986). Estos últimos autores brindaron herramientas fundamentales para el estudio de la comunicación y el carácter dialógico de la actividad discursiva. Así, se le prestó especial atención al carácter de proceso social e ideológico del discurso y la consiguiente relación con la subjetividad del hablante.

El análisis enunciativo plantea un acercamiento al discurso que se delimita por su énfasis en la subjetividad (a partir de las marcas o huellas presentes en los textos) y permite estudiarla en una dimensión discursiva. Siguiendo a Marta Marín, el concepto de enunciación no remite a fenómenos físicos como la fonación o la escritura: "El término refiere a que en un enunciado hay elementos lingüísticos que no tienen el valor de una información que se comunica, son que son huellas que deja en el enunciado el sujeto que lo ha producido" (2008: 78).

La enunciación entonces, se define como un proceso de apropiación en el que existe un locutor que se apropia del aparato formal de la lengua y enuncia su posición de locutor tanto por índices específicos como por medio de procedimientos accesorios: "Esto hace que cada instancia del discurso constituya un centro de referencia interno. Esta situación va a manifestarse a través de un juego de formas específicas cuya función es la de poner al locutor en relación constante y necesaria con su enunciación" (Calsamiglia y Tusón, 1999: 16)

La enunciación es el acto mismo de producir el enunciado. Sus caracteres lingüísticos se encuentran determinados por la relación entre el locutor y la lengua. El acto de la enunciación por lo tanto admite la puesta en funcionamiento de la lengua desde una instancia individual. El denominado locutor actúa como parámetro en las condiciones necesarias para la enunciación. 
Asimismo, a partir de la enunciación la lengua se realiza en una instancia de discurso, en la que un locutor alcanza a un interlocutor y suscita así un proceso de retorno. De esta forma, la relación entre el locutor y la lengua determina los caracteres lingüísticos de la enunciación:

\begin{abstract}
Finalmente, en la enunciación, la lengua se halla empleada en la expresión de cierta relación con el mundo. La condición misma de esta movilización y de esta apropiación de la lengua es, en el locutor, la necesidad de referir por el discurso y, en el otro, la posibilidad de correferir idénticamente, en el consenso pragmático que hace de cada locutor un colocutor. La referencia es parte integrante de la enunciación (Benveniste, 1971: 85).
\end{abstract}

El locutor, por consiguiente, toma a la lengua por instrumento y se sirve de los caracteres lingüísticos para desarrollar la relación. La subjetividad se estructura a través del lenguaje y desde allí el hablante se constituye como sujeto que enuncia su propia subjetividad. Por esto mismo, el locutor asume la lengua, postula siempre un alocutario e integra a la referencialidad como una parte importante de la enunciación.

\title{
2.2.2. Huellas y subjetividades
}

El concepto de enunciado refiere al producto concreto y tangible de un proceso de enunciación, realizado por un enunciador y destinado a un enunciatario. Si bien existen abordajes que los vinculan e incluso los comparan o los incluyen como unidades que presentan las mismas funciones, el enunciado se diferencia de la oración. Esta última puede cumplir el papel de enunciado en tanto represente una idea completa y conclusa, que a su vez se enfrente a otros enunciados ajenos y esté contextualizada por la situación extra-lingüística (escenario, ambiente, prehistoria). En efecto, una oración se transforma en enunciado en el momento en que no necesita relacionarse con otras oraciones propias del contexto discursivo del sujeto hablante, para adquirir significado y sentido:

La gente no hace intercambio de oraciones ni de palabras en un sentido estrictamente lingüístico, ni de conjuntos de palabras; la gente habla por medio de enunciados, que se construyen con la ayuda de las unidades de la lengua que son 
palabras, conjuntos de palabras, oraciones; el enunciado puede ser constituido tanto por una oración como por una palabra, es decir, por una unidad del discurso (principalmente, por una réplica del diálogo), pero no por eso una unidad de la lengua se convierte en una unidad de la comunicación discursiva (Bajtín y Voloshinov, 1998).

En los enunciados convergen las condiciones específicas y las actuaciones lingüísticas en contexto, que incluyen trazos lingüísticos (marcas, marcadores, índices, indicadores, pistas) articulados por el enunciador para que sean interpretados por el enunciatario. Siguiendo los aportes de Bajtín, se puede hablar de tres momentos o factores que se relacionan entre sí en la totalidad del enunciado.

En primer lugar, se señala el sentido del objeto del enunciado en el que es posible abarcar, entender y sentir la intención discursiva o la voluntad discursiva del hablante, que determina todo el enunciado, su volumen, sus límites. En segundo término, se advierte la intencionalidad discursiva, que es el momento subjetivo del enunciado y forma una unidad indisoluble con e aspecto del sentido del objeto. Por último, se aprecian las formas genéricas y estructurales del enunciado, en las que la intención discursiva del hablante, con su individualidad y subjetividad, se aplica y se adapta al género escogido, se forma y se desarrolla dentro de una forma genérica determinada (Bajtín y Voloshinov, 1998).

La subjetividad se estructura a través del lenguaje y desde allí el hablante se constituye como sujeto subjetivo. Por ello mismo, Catherine Kerbrat-Orecchioni establece una distinción entre enunciado y enunciación. En el enunciado, el sujeto hablante se inscribe permanentemente en el interior de su propio discurso y postula un alocutario que se advierte a partir de las huellas o marcas enunciativas. En cambio, la enunciación se define como el mecanismo de producción de un texto, el surgimiento en el enunciado del sujeto de la enunciación y la inserción del hablante en el seno de su habla (1986: 41).

Por tanto, la enunciación estudia las huellas que la enunciación deja en el producto discursivo: es decir, los lugares de inscripción de los diferentes constituyentes del marco enunciativo. Kerbrat-Orecchioni, opone dos tipos de enunciación: mientras que la enunciación "ampliada" describe las relaciones que se tejen entre el enunciado y los diferentes elementos constitutivos del marco enunciativo (protagonistas del discurso, situación de comunicación, ocurrencias espacio temporales, contexto socio-histórico), la 
enunciación "restringida" sólo aborda como hechos enunciativos las huellas lingüísticas del locutor, sus zonas de inscripción y la subjetividad del lenguaje. En este sentido, y con respecto a lo último, la presente tesis doctoral se apoya en la perspectiva de la enunciación "ampliada", puesto que no se hace referencia sólo al momento mismo de enunciación que presentan las líricas, sino se indaga en el marco sociocultural en el que se publican y se interpretan las cuestiones contextuales que integran.

En cuanto a la enunciación restringida, las letras de rock funcionan como piezas discursivas que fundan un mundo, referenciado y problematizado por las situaciones de enunciación. El acercamiento se define por su énfasis en la subjetividad, deteniendo su mirada en las marcas o huellas que subyacen en los textos y admitiendo el estudio desde una dimensión discursiva.

\subsubsection{La enunciación en las letras de rock}

El análisis discursivo en las líricas de rock permite estudiar las estrategias discursivas articuladas por agentes únicos, válidos para identificar objetos y acontecimientos dentro del mundo lírico. Lo que interesa subrayar entonces es que la realidad se opera desde una instancia de transformación a fin de destacar intereses ideológicos y, claro está, de defensa y cimentación de ideas. Las letras de rock, como cualquier producto artístico, provocan modelos del mundo y se rigen por reglas de un juego retórico. Las líricas se encuentran vinculadas fuertemente con las convenciones culturales que, en muchos sentidos, configuran una trama dialéctica con el contexto histórico.

El estudio del discurso, por consiguiente, admite una teoría de la instancia de enunciación y es, integralmente, un efecto de enunciado. La instancia de enunciación es un efecto de enunciado que debe ser reconstruido o "descubierto" por un esfuerzo de interpretación (Parret, 1983). El concepto de enunciación comprende una serie de elementos que pertenecen al código de la lengua y cuyo sentido se vincula con la retención de la huella del proceso de enunciación en el enunciado determinado (Ducrot y Todorov, 1986).

El análisis discursivo refiere a versos integrados a una música, es decir, textos para ser escuchados que, en otra ocasión, podrían todavía estudiarse en una íntima relación con 
ella (Conde, 2007: 16) ${ }^{1}$. Por consiguiente, las estrategias discursivas que abordan una tematización de la libertad como un eje primordial en un proceso de construcción democrática, forman parte del contexto en la que surgen al mismo tiempo que lo constituyen. Ante esto, y siguiendo a Oscar Blanco, el rock y sus letras forma parte de la cultura política y propone, asimismo, rupturas sobre los modos y estructuras que subvierten la libertad: "Las letras de rock presentan un efecto de crónica y de testimonio, todo esto sustentado, las más de las veces, sobre principios libertarios" (2013: 1).

De acuerdo con ello, ciertas palabras y/o expresiones manifiestan evaluaciones del hablante a partir del nombramiento de ciertos objetos (sustantivos) o hechos del mundo que refiere. El análisis de la enunciación plantea así un acercamiento al discurso que se define por su énfasis en la subjetividad (a partir de las marcas o huellas que esta deja en los textos) y permite estudiarla en una dimensión discursiva. En el enunciado, el locutor manifiesta valoraciones de su entorno cultural e ideológico. De este modo, las huellas se comprenden como frases, palabras, morfemas o entonaciones particulares que permiten comprender una selección discursiva en el marco de una situación comunicativa (Balmayor, 1997: 119)

\subsection{Libertad}

La definición del concepto de libertad atrae complejidades y debates al momento de arribar definiciones y acepciones determinadas. Como punto de partida, es posible aclarar que la libertad es una fuente garantizada y permanente para el desarrollo existencial de los sujetos en sociedad. Por esta razón, la libertad constituye la posibilidad de construir las relaciones sociales y de estabilizar los cimientos de las estructuras de convivencia y de práctica de los hombres y las mujeres.

Como valor fundamental, la libertad es importante y es tan sólo una concepción en todo momento, aunque los usos de la libertad sean muchos en su abordaje. La contemplación de la libertad puede establecer una configuración en particular, pero también puede advertir distintas libertades que constituyen una sola libertad, la cual se completa, se

\footnotetext{
${ }^{1}$ El análisis discursivo desarrollado en esta tesis apuntó a una materialidad de líricas discursivas. No obstante, la reserva del análisis musical se dispone para los especialistas en esa materia que, sin embargo, puede relacionarse con este tipo de intención de explicación lingüística.
} 
complementa y se declina en plural (Mazzina, 2007: 43).

Si bien libertad tiene una definición conceptual que requiere una problematización, su exploración en un terreno de cultura plantea una disquisición provisional y esencialista que activa la discusión. La libertad, por lo tanto, concierne convicciones personales que rechazan restricciones y persiguen deseos particulares para la existencia.

Continuando la idea planteada por el historiador Orlando Patterson, la libertad es una palabra clave en toda instancia política, discutida interminablemente por su naturaleza y significación. Es también una línea primordial para comprender factores económicos y decisiones políticas y sociales. Es también un valor central del cristianismo, a partir de la concepción libertaria de la redención y las situaciones que implican el desempeño religioso en un mundo secular:

No es posible comprender la historia moderna de la libertad sin apreciar cabalmente el hecho de que la libertad ha sido el valor central y nuclear de la cultura occidental durante toda su historia (...) La gente llegó a valorar la libertad y a construirla como poderosa y compartida visión de vida a resultas de su experiencia de $-\mathrm{y}$ respuesta a- la esclavitud o su forma derivada, la servidumbre, una experiencia que se hizo en los roles de amo, de esclavo y de no esclavo (1991: 16).

En función de ello, la conceptualización de la libertad tiene una historicidad que atraviesa pensamientos históricos, desde la lógica griega hasta las disposiciones teóricas de la revolución francesa y las manifestaciones liberales del siglo XX. En efecto, la libertad en la historia contemporánea representa una esfera de actividad humana, amparada por la ley y la seguridad jurídica, en tanto que comprende que existe una idea liberal de la nación, el estado y los individuos.

La libertad es, esencialmente, una distribución de desarrollos y soberanías. Pero, al mismo tiempo, implica un destaque de civilidad, a partir del reconocimiento de la convivencia y el respeto: "La existencia de libertad cívica supone una comunidad política de algún tipo, que establezca claramente derechos y obligaciones para cada ciudadanos" (Patterson, 1991: 30).

En relación con las ideas políticas de Jean-Jaques Rousseau y su consiguiente impacto en el desarrollo de la revolución francesa, la libertad solo puede instaurarse en la organización social que crean los hombres para articular prácticas y quehaceres de vida. 
De esta suerte, en El contrato social se desarrolla el desplazamiento hacia un "estado de la sociedad" y de una denominada libertad convencional. La libertad no materializa un único fin de poseer, sino es pensada como una exigencia para la dignidad humana. En efecto, la libertad resulta un valor en sí y actúa como fuente de todos los derechos: "La libertad consiste en poder hacer todo lo que no dañe a otro (...) el ejercicio del derecho natural de cada hombre no tiene mas límites que aquellos que aseguran a los demás miembros de la sociedad el goce de los mismos derechos" (1963:69).

En un sentido similar, el pensador francés Barón de Montesquieu comprende a la libertad como el derecho de hacer lo que las leyes permitan y de obtener la tranquilidad de espíritu que proviene de la confianza y la seguridad personal: "La libertad política de un ciudadano depende de la tranquilidad de espíritu que nace de la opinión que tiene cada uno de su seguridad. Y para que exista libertad es necesario que el gobierno sea tal que ningún ciudadano pueda temer nada de otro" (2003: 206).

El filósofo inglés y reconocido padre del liberalismo, John Locke, definió a la libertad como una instancia que consiste en tener una norma permanente establecida por el poder legislativo que ha sido erigido dentro de una sociedad: "una libertad para seguir los dictados de mi propia voluntad en todas esas cosas que no han sido prescritas por dicha norma, un no estar sujetos a la inconstante, incierta desconocida y arbitraria voluntad de otro hombre" (2006: 9).

Por consiguiente, el filósofo inglés Thomas Hobbes definió la libertad como la ausencia de impedimentos externos, que a menudo pueden arrebatarle a un hombre la oportunidad de hacer lo que le plazca, pero no pueden imposibilitarle el uso del poder que le resta de acuerdo con lo que le dicte su juicio y su razón:

Respecto a la concepción del individuo, tanto Hobbes como Locke pensaban que al no estar sometido a un Estado, el hombre entonces vivía en estado natural, aunque para el primero esa situación era la de un salvaje, mientras que para el segundo, éste era un ser ideal. Ambos definieron el estado natural como opuesto a la libertad civil en términos de independencia del hombre. En el estado natural el hombre tenía independencia limitada porque está a expensas de otras fuerzas, aunque tenía independencia absoluta respecto a un gobierno o a las leyes (Buelna Serrano; Gutiérrez; Ávila, 51: 2009). 
Al respecto, la concepción del filósofo y político inglés John Stuart Mill manifiesta que la libertad humana exige libertad en nuestros gustos y en la determinación de nuestros propios fines. La concepción de Mill sobre la libertad, retoma las consideraciones de Joseph Priestley y Josiah Warren, y señala que el individuo ha de ser libre para hacer cuanto desee mientras no dañe al prójimo. Cada persona es por sí misma suficientemente racional para poder tomar decisiones acerca de su propio bien y elegir asimismo la religión que le plazca.

Es decir que la libertad contribuye a trazar el plan de existencia en el mundo según el propio carácter para obrar como se desea y a partir de la consideración de nuestros actos: "sin que nos lo impidan nuestros semejantes en tanto no les perjudiquemos, aun cuando ellos puedan pensar que nuestra conducta es loca, perversa o equivocada" (1970: 71-72).

En este sentido, en su reconocido Ensayo sobre la libertad, Mill sostiene que la libertad está limitada por el poder que ejerce la sociedad sobre el individuo y por la conciencia de una convivencia social para el desarrollo de la integridad del individuo. La libertad del individuo se postula como un bien necesario: relacionada con una concepción humanista que no coloca a la libertad como un fin, sino como un medio útil para desarrollar un espacio de expresión y plenitud.

\subsubsection{Un entorno de negociación y clasificación}

La libertad puede clasificarse a partir de un contenido de construcciones distintivas que se encuentran interrelacionadas y superpuestas. En función de ello, existen cuatro dimensiones que admiten una relación constitutiva, eleccionaria, moral y social/política de la libertad.

La primera refiere a la dimensión del "ser libre" y su posicionamiento en la realidad a partir de elecciones, decisiones y el compromiso de sus actos. La libertad fundamental se continúa en el libre albedrío, en la libertad moral y en la libertad pública: "El querer se realiza efectivamente en el elegir y en el poder y los implica y, a su vez, el poder implica el elegir y el querer" (Vicente Arregui y Choza, 1997).

La libertad de elección, como segunda dimensión, se vincula con los modos de actuar en un caso determinado (con las instancias electivas de la situación: evaluación de posibilidades y correspondiente selección). La libertad se manifiesta así cuando la persona selecciona desde un ejercicio de libre albedrío que conduce un desarrollo de 
conducta.

La libertad moral, en tercera instancia, consiste en la realización de la libertad fundamental en el transcurso de la existencia, en la tarea de ejercer las prácticas y abordar una propia biografía. La libertad, en esta instancia, no es algo dado, sino aquello que los sujetos deben lograr para tomar decisiones libres: "La libertad se ve así como una ganancia, como un progreso hacia la propia perfección. El proyecto existencial puede configurarse de tal manera que permite al sujeto conquistar su libertad, hacerse libre y realizarse a través de sus acciones" (Stork, 1988: 172).

En cuarto lugar, la libertad debe llevarse a cabo en un ámbito social/político favorable que se caracteriza en lo que debe ser permitido y en posibilidad de autorrealización. Así, desde una configuración política se comprende que la persona puede ser en sí misma y puede trascender, crear, desplegar su fuerza en el universo social: "Ejercer esta libertad sólo será posible dentro de un marco que le asegure su libertad social y política: los demás han de permitir con su conducta que cada persona pueda llegar a ser lo que quiera ser" (Debeljuh, 2003: 96).

La libertad también forma parte de un plazo de negociación que se distingue en relación con lo que se pretende ser en la vida. En este sentido, conviene retomar lo propuesto por Paul Ricoeur y considerar que las instancias de la libertad pueden convivir en una trama que puede tornarse abstracta, política e instituyente. Por consiguiente, Ricoeur entiende que la libertad es una cuestión de poderes: el poder de la alternativa, el poder sobre los contrarios, el poder de preferir, elegir y reflexionar (1986: 172).

Desde esta óptica, la trama de la libertad tiene tres etapas. La primera se vincula con un espacio abstracto, sin intermediarios, retirado de las circunstancias y que se excluye de las consideraciones políticas. En este sentido, la libertad se vincula con un manifiesto kantiano, relacionado con el mundo interior y las obligaciones o deberes de los hombres en la tierra (Ricoeur: 1986: 173).

La segunda etapa de la libertad se enlaza con una reflexión concreta: es decir, una filosofía que tiene en cuenta las libertades políticas y personales, económicas y sociales. En términos de Ricoeur, es una libertad concreta que se posiciona de un modo valiente y considerado hacia el Estado y las políticas de existencia: “(Asume) la ley del orden, que es la ley de lo infinito, dar forma y, al dar forma, toma forma, de ahí la libertad" (1986: 183).

La última etapa registra una contención de las partes anteriormente detalladas y considera un sentido de contexto político contemporáneo. Del mismo modo, plantea 
también un conflicto constante entre los requerimientos de la libertad individual y los del ejercicio del poder. En consecuencia, la presencia de la libertad admite una instancia de tensión que se articula a partir de voluntades, exigencias, esperanzas y apetitos (Ricoeur, 1986: 190).

Del mismo modo, es plausible identificar ciertas nociones que sirven a la luz de pensar a la libertad como un vehículo de configuración política en sociedad. Como también señala Giovanni Sartori desde la ciencia política, el abordaje de la libertad en torno a lo político, es decir, el ciudadano libre, existe en tanto en cuanto se crean las condiciones que permiten a este poder menor resistir al poder superior que, de otra forma, le aplastaría o, al menos, podría hacerlo. La libertad política "es inconfundiblemente libertad de, no libertad para (...) el concepto de libertad política tiene una connotación de resistencia. Es libertad de porque es la libertad del y para el débil (...) Lo que pedimos de la libertad política es la protección contra el poder arbitrario y despótico" (Sartori: 2003: 279)

Finalmente, y en términos sociológicos, Zygmunt Bauman señala que la significación de la libertad admite la capacidad de decidir y elegir, pero nunca se da en su totalidad porque los sujetos están determinados por acciones pasadas. En este sentido, la libertad expone una situación dual porque resulta un anhelo prometedor que amplía horizontes de decisión y, asimismo, conlleva una responsabilidad que condiciona las circunstancias de vivir en una sociedad (2003: 27).

\subsubsection{La distinción negativa y positiva}

La libertad ha sido construida desde distintos sentidos a lo largo de la historia. Con la intención de encontrar un punto de encuentro o un modo de nuclear ciertas acepciones, el pensador liberal Isahiah Berlín sostiene una postura relevante en torno a la significación de la libertad. Por esto mismo, el autor diagrama dos conceptos nodales y complejos para comprender a la libertad: la instancia negativa y el aspecto positivo.

Por esto mismo, en su célebre ensayo Dos conceptos de libertad señala una doble estrategia para ingresar en el debate en relación con el significado de la libertad, no sin antes mencionar que no hay un modo categórico de atravesar su conceptualización. La Libertad positiva y la libertad negativa son dos acepciones disímiles y conflictivas. Sobre la libertad negativa, Berlín sostiene que las definiciones pueden alinearse en virtud de tres identificaciones. Por un lado, se relaciona con un ámbito o área de no 
interferencia, es decir, de libertad de desempeño. En segundo término, un área en la que los sujetos son sus propios dueños y dan cuenta de su propia autonomía. Y la última establece una zona con posibilidades de elección y acción:

La libertad negativa es algo cuya extensión, en un caso dado, es difícil de estimar (...) parece depender: a) de cuántas posibilidades tengo abiertas (...); b) de la facilidad o dificultad para que cada una se realice; c) de la importancia que tienen estas posibilidades en mi plan de vida, dados mi carácter y mis circunstancias, cuando las comparo entre sí; d) de hasta qué punto están abiertas o cerradas por actos humanos deliberados; e) del valor que no solo el agente, sino también el sentimiento general de la sociedad en la que vive, atribuye a las diferentes posibilidades (1958:130).

La libertad positiva, por consiguiente, surge de un deseo propio de los sujetos que implica tomar el timón personal. En este sentido, se introduce una gran complejidad en la que se mezclan aspectos internos de la moralidad y la política como autogobierno colectivo. La libertad positiva se identifica entonces, con nociones autorreguladoras: desde la autonomía y la autodeterminación hasta la autorrealización personal. La libertad positiva postula un desarrollo en el sujeto libre, que determina y cambia sus propios deseos e intereses autónomamente a partir de una autorrealización:

El sentido 'positivo' de la palabra 'libertad' se deriva del deseo por parte del individuo de ser su propio dueño. Quiero que mi vida y decisiones dependan de mí, no de la voluntad de otros hombres (...) Deseo ser alguien en vez de nadie; un realizador - alguien que decide por sí y no que los demás decidan por él. (...) Deseo, sobre todo, ser consciente de mí mismo como un ser pensante, decisivo, activo, responsable de mis elecciones y capaz de explicarlas por referencia a mis ideas y objetivos (158: 131).

Desde esta perspectiva, Berlín apuesta por la autonomía personal ante los ataques de dominación y avasallamiento individual. En efecto, la crítica radica en interpretar que la dinámica entre libertad negativa y la libertad positiva se diferencia en la acción social, mientras que la primera tiene una vertiente política, la segunda puede conducir a un despotismo irracional. A pesar de ello, el verdadero criterio de Berlín se establece a partir de las concepciones primordiales de la libertad negativa: el hombre puede pensar 
y puede actuar en oposición a condiciones externas. La libertad, para este autor, puede sostenerse a partir del entendimiento de una libertad que tienen los sujetos de escoger y construirse desde sus propias selecciones de vida.

\subsubsection{La pregunta sobre la libertad}

En esta tesis, la tematización de la libertad se aborda como referencia de los sentidos, perspectivas y modificaciones articuladas en las líricas de rock seleccionadas como corpus $^{2}$. Así, es posible comprender que las letras de rock se instituyen a partir del compartimiento de significados y unidades sociales que tienen en común valores, reglas de convivencia, actuación y modos de vida (Conde, 2003). Ante esto, la pregunta sobre la libertad resulta importante porque atañe al período mencionado para investigar y porque se configura como un valor supremo en la creación artística de los artistas de cultura rock.

La libertad atraviesa indivisiblemente la idiosincrasia de la cultura rock. Desde sus comienzos, hacia mediados del 50 hasta la actualidad, la cuestión de la liberación y del ser libre se ha mostrado como una invariable histórica. Se ha consagrado como un afán y un objetivo postulado de un modo reiterado. De mismo modo, se mostró influenciado por los cambios de época y las modalidades presentes en los años o las décadas de producción de discos y canciones, líricas o discursos.

El rock y las distintas variantes de sus géneros pasan a ser el sentido común de una forma de liberación personal, de búsqueda de autonomía en procura de una vida menos injusta, e impuesta, en detrimento de la repetición y la aceptación pasiva, el formalismo y la solemnidad. La pregunta sobre la libertad permite reflexionar sobre las nociones morales, voluntaristas y expectantes que presenta el rock argentino y sobre la incidencia de estas valoraciones en el espacio social joven.

\footnotetext{
2 Vale destacar que hasta la década del 90, el desarrollo del rock en la Argentina se centró, primordialmente, en las clases medias urbanas de Ciudad de Buenos Aires, Rosario, Córdoba y Mendoza. Si bien, esta regla podría ofrecer algunas excepciones (Vox Dei, V8 o Hermética, por ejemplo), se considera a la clase media urbana como el estrato que nutrió al movimiento de los músicos y compositores que más han influido en las formas musicales que se desarrollaron desde la mitad de los años 60 hasta buena parte de la década del 90 (Semán, 2005). De hecho, de dicha fracción social provienen los artistas históricos y consagrados del rock argentino (Litto Nebbia, Luis Alberto Spinetta, Charly García, Gustavo Cerati o Indio Solari, entre otros).
} 
Por lo tanto, resulta interesante abordar la libertad como una moral entendida desde la autonomía y desde el pluralismo como camino para representar a los sujetos de la sociedad. La libertad se adscribe a personas y/o a acciones en virtud de ciertas condiciones. Se marca así el aspecto dialéctico de la libertad en relación con el medio institucional y social para su despliegue y la capacidad normativamente estructurada de los artistas en un contexto determinado (Hoyos, 2009).

Las letras de rock contienen una construcción de valores que postula diferentes modos de conceptualizar y tematizar a la libertad en contextos diversos. Así, se considera a la libertad desde estructuras íntimas, pero también a partir de las condiciones de existencia. En función de ello, las letras de la cultura rock se encuentran enmarcados por nociones que tienen conciencia de la esencia y la autenticidad a fin de exigir transformaciones y disputas en un ámbito de conmoción social.

\subsection{Transición democrática}

El período que aborda este trabajo de investigación subyace, como se evidencia, una discusión sobre el alcance del término libertad en un marco de cultura rock, y también un debate sobre la concepción de la democracia como oposición al Terrorismo de Estado. Si bien el término democracia nace en la antigua Grecia, se advierte que su contenido se resignifica a partir de los contextos y se comporta como un significante en disputa y con sentidos diversos.

Al respecto, la reflexión sobre la noción de democracia advierte una complejidad porque su significación integra términos clave como los de ciudadanía, soberanía, instituciones, orden público y pluralidad, por citar algunos ejemplos. Por tanto, la conceptualización de la democracia se articula a partir de dos distinciones fundamentales, puesto que es comprendida como el gobierno del pueblo y como el gobierno para el pueblo. La primera lleva inscriptas las consideraciones del pensamiento griego, en el que la soberanía provenía de la igualdad de los ciudadanos para ejercer su palabra en la asamblea y ante la ley. La segunda permite distinguirla como un ideal de igualdad que coloca al Estado como agente primordial para alcanzar dicha meta.

En términos de Ernesto Laclau, la definición de la democracia resulta volátil, y aunque se considere que no tiene un contenido inscripto específico en el seno de una formación discursiva "todo depende del sistema de articulaciones diferenciales y equivalenciales dentro del cual está situado" (2005: 22). La democracia, desde la perspectiva 
contemporánea y moderna, incluye a la libertad y, de acuerdo con Giddens, advierte un "doble filo" que compromete la propia reflexión democrática porque articula tanto la libertad política como la libertad económica. Si bien la primera se encuentra vinculada con la noción de los derechos humanos y la segunda se funda en el mercado y la elección, ambas promueven una instancia desigualadora que no logra completar la democracia (Saavedra y Cabrera, 2005: 185).

Siguiendo a Juan Carlos Portantiero, la democracia no es un lugar ni un punto en el espacio al cual se debe llegar, es, más bien, el espacio en donde deben dirimirse los conflictos sociales (1997: 14). Estos últimos, precisamente, contienen las dinámicas que mueven la historia de los hombres, con expectativa de cambio y transformación incluidas: "Lo procesos de transición democrática que vivió el sur de Europa en los 70, que vivió América Latina en los 80 (...) son procesos que por comodidad expresiva llamamos de transición, pero que, en realidad, en sí mismos cobijan varias transiciones" (1997: 14).

De acuerdo con Guillermo O'Donnell y Philippe Schmitter, se entiende por "transición" al intervalo que se extiende entre un régimen político y otro, en este caso, refiere directamente al comienzo del proceso de disolución de un régimen autoritario y el establecimiento de alguna forma de democracia (2010: 28). Lo característico de la transición es que es un proceso complejo de transiciones que se van desplegando secuencialmente (Portantiero, 1997: 14).

Del mismo modo, es un transcurso en el que las reglas del juego político no se encuentran definidas ni se hallan en flujo permanente: por lo general, son objeto de ardua contienda; "los actores luchan no sólo por satisfacer sus intereses inmediatos y/o los de aquellos que dicen representar, sino también por definir las reglas $\mathrm{y}$ procedimientos cuya configuración determinará probablemente quiénes serán en el futuro los perdedores y los ganadores" (2010: 28).

En tanto, la denominada transición democrática implica, según Aníbal Ford, una instancia de profundización o construcción abierta de la democracia, como un proceso, siempre imperfecto, que puede realizarse de diferentes maneras (1996: 195). Considerando el plano historiográfico del país, la construcción del concepto transición también incluye actualmente una definición de "recuperación democrática", de “democracia en reconstrucción” (Fabris y Tortorella, 2011) o, como habitualmente se la conoce en Argentina, de "primavera democrática" o "primavera alfonsinista". 
A partir de ello, los tiempos de la llamada transición democrática constituyeron tramas inciertas, ambiguas y plagadas de continuidades y disyuntivas con resoluciones confusas y complejas. Sin dudas, se sostuvo a partir de un discurso de cambio epocal, de destaque esperanzador, caracterizado por profundas transformaciones individuales y colectivas. De esta manera, la constitución de democracia revalorizada centralizaba la esperanza de las resoluciones de las demandas y no representaba un problema en sí mismo (Lechner, 1990).

\subsubsection{La transición democrática argentina}

En la Argentina, la transición democrática se inició a partir del colapso del régimen militar, pero aún se plantean diversas zonas de origen. Ernesto López y Guillermo O’Donell, por ejemplo, señalan que el proceso de consideración democrática comenzó en marzo de 1980, cuando el dictador Videla convocó al diálogo político. Del mismo modo, hay autores que sitúan el comienzo de la apertura democrática (al menos en términos discursivos) durante el breve mandato del dictador Viola. No obstante ello, en esta tesis se comprende que esos dos momentos no dieron el espacio para recorrer una instancia de transición. En este sentido, se entiende que la trayectoria hacia la democracia empezó tras la derrota de Malvinas y la salida intempestiva del dictador Galtieri en junio de 1982.

La transición democrática, en efecto, produjo la apertura de una instalación cultural de la convivencia cultural y habilitó un mecanismo para generar un nuevo eje articulador del debate político. Se abrió así un proceso de democratización repleto de nuevos contenidos que constituyó un fuerte y activo consenso social, que hizo hincapié en la jerarquía de valores. Se propuso así la vigencia de la soberanía popular y la defensa paulatina, pero firme de la democracia ante los arrebatos golpistas (López, 1994: 139).

En términos de Cecilia Lesgart, la presentación de la idea de democracia como objetivo deseable se produjo a partir del resquebrajamiento de los regímenes dictatoriales en otros países y respondió al impacto personal y colectivo causado por las dictaduras más violentas, como la de Argentina: "De aquí que la democracia, pensada en oposición a la evaluación de las causas que habían conducido a los autoritarismos, adquiriera valor en sí misma, se pensara como la elección del mejor régimen político (si existía la opción de organizarla políticamente)" (2003: 182). 
En consecuencia, luego de la guerra de Malvinas, la terminología de la democracia se construyó como un opuesto contrastante al término autoritarismo, que era utilizado "omniabarcativo" a fin de describir y evaluar tanto el pasado más lejano de las dictaduras del país como el más reciente desde una instancia negativa (2003: 188). En segundo lugar, la concepción de democracia se constituyó en consonancia con los eventos que trajo consigo la posguerra, es decir, los nuevos aires del liberalismo político provenientes de Europa (Francia y España, preferentemente) y los estamentos de un Estado de Derecho. Ambos fueron entendidos como remedio para "deslindar las persecuciones, los encarcelamientos, las desapariciones, de la libertad y construir instituciones que aseguraran las garantías individuales otorgadas por los llamados derechos civiles" (2003: 189).

No obstante ello, el fin de la dictadura no garantizó la conformación instantánea de un régimen democrático en su estricta definición política, sino expuso una débil institucionalización democrática tanto en la Argentina como en el resto de los países latinoamericanos que habían sufrido tortuosos procesos militares. El advenimiento del gobierno democrático, asociado al alfonsinismo, no produjo una condena masiva e instantánea de la represión y las violaciones de los derechos humanos, ni tampoco dispuso el lugar transformacional de la justicia o provocó un discurso directo enraizado en la llamada "teoría de los dos demonios".

Si bien, el signo de la nueva democracia fue antidictatorial, también tuvo instancias graduales que significaron cambios de percepciones paulatinos sobre el proceso político, cultural y social del régimen militar. En todo caso, la democracia emergió como alternativa frente a la necesidad del fin dictatorial y dispuso una transformación de la dimensión cultural: los derechos del individuo y su libertad cobraron valor en rigor de la temática democrática. El nuevo régimen ofrecía "la posibilidad, entonces, de conjugar libertad individual y justicia social, por un lado, y democratización cultural y de la vida cotidiana por el otro" (Ollier, 2009: 239).

\subsubsection{Democracia y libertad}

En la Argentina pos dictatorial, las nociones conceptuales del término "transición", como señalan Guber y Visacovsky, se conformaron a partir de la enunciación de los intelectuales orgánicos y no orgánicos de la época. En función de ello, se suponía un modelo de acción basado en las expectativas de revertir profundamente el pensamiento 
político del pasado (2005: 34). Justamente, la categoría de "transición" actuaba y direccionaba el proceso de la democracia desde un proceso complejo, abierto a las alternativas y también condicionado por ciertas continuidades prácticas y vivenciales. En coincidencia con lo propuesto por Claudia Feld y Marina Franco, las operaciones discursivas vinculadas con la dictadura constituyeron características propias que puede entenderse a partir de seis claves:

En primer lugar, la transición estuvo atravesada por permanentes disputas políticas y de sentido en lo que se advertían incertidumbres e inseguridades sobre el futuro. En segundo término, se advierten continuidades directas con el pasado dictatorial y de sus procesos previos, en las que sobresalen percepciones de riesgo y peligro.

En tercera instancia, se exponen contradicciones propias de una coyuntura de reconfiguración y revalorización.

En cuarto lugar, se aprecian discusiones políticas o sociales que, a pesar de su relevancia en el momento, no han llegado a ser dominantes en años subsiguientes. Como quinto aspecto, se detallan escenarios de prueba y error en relación con las posiciones, acciones, concepciones y decisiones sobre la transición.

Por último, se aprecian los límites de lo enunciable y/o decible en relación con un universo discursivo articulado a partir de opacidades e intentos de rupturas con lenguajes previos (2015: 365-366).

El pensamiento de los 80 habilitó así un tiempo de re-configuración de la percepción del estado y de la sociedad civil. Por esto mismo, el pensamiento liberal se apartaba de los brazos del Estado y lo relacionaba con la opresión y la persecución política. En detrimento, la conformación de una sociedad democrática planteaba perspectivas favorables en la que todos los individuos se apreciaban libres y proponían una situación autónoma de oposición: se constituía un enfrentamiento contra el Estado (que aún se encontraba vinculado con los atropellos, las amenazas y las violaciones más íntimas), las corporaciones y las posturas diversas de represión y control:

“La idea de 'transición', entonces, era una idea interesante en los ochenta, dado que la tarea que teníamos por delante era la de recorrer un camino al final del cual, como resultado, estaba esa utopía de la libertad realizada a la que llamábamos 'democracia'. La idea de democracia de los años ochenta estaba asociada a la 
noción de la libertad y aquella utopía democrática era una utopía de las libertades" (Rinesi, 2010: 31).

El filósofo Eduardo Rinesi habla de una utopía democrática de los 80 que se vinculaba con un ideal de la plena realización de la libertad, o de las libertades. En este aspecto, el autor sostiene que el problema de la libertad fue de los más conversados y de los más discutidos en los ámbitos sociales durante los años de transición democrática. La de democracia "participativa" entonces, era pensada como una garantía para el amplio ejercicio de una libertad "positiva" para intervenir activamente en los asuntos públicos. La democracia "representativa", en tanto, perseguía la consolidación de una libertad "negativa", salvaguardada de las interferencias externas sobre las opciones de vida:

En la universidad fueron años en los que volvimos a pensar en términos teóricos y filosóficos este viejo problema de la libertad, y en los que para ello volvimos a leer a los clásicos y revisamos los textos de Stuart Mill y de Benjamin Constant y de Isaiah Berlin, y en los que pensamos y discutimos la contraposición entre la libertad de los antiguos y la de los modernos, entre la libertad "para" y la libertad “de", entre la libertad "democrática" y la libertad "liberal" (2010: 31).

Estos aspectos son posibles de ser encontrados en las líricas de rock a analizar, puesto que se encuentran atravesadas por nociones que postulan libertades de acción y voluntades de liberación que se relacionan con un escenario de reconstrucción social. De esta manera, las letras seleccionadas para el corpus exponen un manifiesto que activa situaciones de crisis y de enfrentamiento con las condiciones sociales que avasallan libertades.

\subsection{Cultura rock}

A más de cincuenta años de su nacimiento, la cultura rock continúa siendo una práctica social que se retroalimenta a partir de debates, complejidades y expresiones que rearman estéticas y modos de concebir los acontecimientos de la vida social. La cultura rock se configura como un campo de contradicciones, aciertos y desacuerdos en el marco de la sociedad contemporánea. En este sentido, permite la convergencia de distintas perspectivas que postulan un estado de incomodidad y de reconfiguración identitaria dentro de la industria cultural. Es decir que plantea una tensión constante con 
las reglas del sistema y se constituye a partir de la crítica y el desafío.

En términos de Philippe Paraire, el rock es un fenómeno que contiene, interpela y considera a la juventud como sujeto social (1992: 10), a pesar de la disparidad de lugares que atraviesa y de los géneros musicales o cualidades que la conforman: "No se puede examinar de otra manera que como una cultura con derecho propio, compuesta de actitudes, recorrida por temas, amplificada por soportes y caracterizada por temas que definen escuelas y estilos" (1992: 10).

La cultura rock instituye, desde sus discursos y prácticas, una sucesión de representaciones sociales (ideológicas) sobre la creación musical y la vida de los jóvenes en sociedad. El rock se postula, de este modo, como un sistema discursivo que supera al género musical y que comparte (en sus intenciones y producciones) los efectos de la comercialización e industrialización de la producción musical a partir de negociaciones y luchas en la arena cultural.

En función de ello, Sergio Pujol señala que la cultura rock presupone un tenso equilibrio entre la negociación, el conflicto, la innovación y la resistencia: “¿Acaso no es el rock, en su tumultuoso devenir, testigo y actor, documento e instigador de la vida en sociedad de los jóvenes?" (2006: 12).

En consonancia, el rock actúa en un universo social y propone una instancia simbólica a partir de sus prácticas. Como señala Augusto Di Marco, el rock es una expresión artística nacida en la ciudad y su lenguaje y su simbología se aprecian en relación con lo urbano y la hibridez existente:

Es baile, pero también postura frente a la sociedad; es estética y al mismo tiempo ideología en un sentido amplio" (1994: 31) (...) Al principio fue considerado como un fenómeno musical adolescente. Luego se vio al rock como una contracultura, sobre todo durante el auge del hippismo y, años más tarde, del punk. También el rock ha sido considerado como una forma artística, aunque a veces no cuadre dentro del marco de lo tradicionalmente considerado como arte; con el tiempo, el rock fue visto como cultura de masas (1994: 38).

Particularmente, el rock argentino es un fenómeno cultural complejo que representa todo un compendio de experiencias que exceden lo meramente musical y lírico. Es una práctica contracultural de identificación juvenil que se muestra rebelde, se entiende contestataria, y que sienta sus bases en la provocación y en la transgresión. Por tanto, el 
rock se opone a las formas culturales convencionales (estilos de vida, vínculos sociales o tradiciones) y propone su particular mirada sobre hechos y costumbres de la sociedad en general. Desde ese lugar, se vincula con un inicio rupturista, conmovedor y de vertiente contracultural.

Las líricas de rock cumplen un papel primordial de enlace en la relación comunicación y cultura, puesto que desde sus instancias discursivas, impulsan un mecanismo activador de diálogo, debate e interacción entre los jóvenes y las distintas instancias generacionales de la sociedad (Pujol: 2005, 2007). El mensaje producido y construido estratégicamente en base de lírica rock, articula significados, prácticas y modos de decir de la actividad social del rock, en principio, y de los procedimientos sociales, en segunda instancia.

Las letras de rock se potencian y se erigen como fenómenos culturales que forman parte de la realidad en la que surgen al mismo tiempo que la constituyen. En consecuencia, el estudio concreto las postula como piezas discursivas plausible de ser analizadas por categorías que permiten detectar las huellas subjetivas y las intencionalidades de locutor creador del mundo discursivo.

Se desempeñan entonces, como canales expresivos que enuncian experiencias sustanciales de comunicación y representan malestares, problemáticas humanas y propios quehaceres de una sociedad en crisis y en re-configuración democrática. La comunicación establecida constituye un desafío de pensamiento y contribuye a la consolidación de valores, aspectos democráticos y abordajes identitarios: concentran así un sentido esencial de compartimiento, intercambio y puesta en debate con el oyenteespectador-lector.

\subsubsection{Orientación pop}

El marco temporal seleccionado (1982-1989) admite la re-conceptualización del carácter masivo de la comunicación y el replanteo del pop como objeto dominante de la cultura rock. En este sentido, la efervescencia pop del rock argentino se montó en una cresta de una ola de repercusión sin antecedentes. La explosión que se efectuó en el período dio pie para que las discográficas y las editoriales celebrasen la historia del rock argentino y reafirmen el lugar del pop en el universo de dicha cultura. 
La irrupción de la estética y el estilo punk $k^{3}$ conmovió fuertemente las cosmovisiones de la cultura rock a nivel global. Se produjo así una expresión instantánea que, entre nociones de rechazo hacia el mundo preestablecido y la idea de la destrucción como manifiesto nihilista, trastocó los estamentos del universo del rock. Este último se encontraba, hacia mediados de los 70, cultivando una densidad elitista y acartonada que forjaba instancias previsibles y cómodas, a pesar de sus constantes intentos de contrariar el sistema adulto y conservador. El punk, por su parte, recuperó la corporalidad en la escena de comunión rockera y fomentó la simplicidad en la comunicación (lírica, sonora y visual).

Vale destacar que el dominio del punk como respuesta sonora y estilística no tuvo una duración extendida en la industria cultural, no obstante, su influencia perduró a lo largo de los años y continuó desordenando los postulados libertarios de la cultura rock. El punk, primordialmente, logró el enlace entre las búsquedas auténticas y emancipatorias del rock y las nociones comerciales, pero también díscolas propuestas por la estética pop. Así, el tránsito del rock hacia el pop se abrió en pos de una lógica joven, de ruptura y ocurrencia.

De acuerdo con Pujol, el giro semántico del pop le dio un tono particular a la escena musical de la década del 80. De este modo, los grupos y solistas emergentes se ocupan de su imagen, acentuando la teatralidad y una frescura preocupada por resaltar la composición adolescente de los primeros discos de Los Beatles o The Who:

La idea de que no hay que tomarse las cosas tan en serio se impone aquí y allá. En algún punto el rock podrá seguir siendo rebelde y díscolo, pero ya no candoroso (...) La ironía gana espacio, muy cerca de la parodia (...) Los músicos reinventan tradiciones, vuelven libremente al pasado y coquetean con el romanticismo, pero siempre mostrando las costuras (los procedimientos), tomando cierta distancia y dando a entender que el simulacro es la clave de nuestra cultura. En efecto, se advirtió una impresión de música ligera y desapasionada tiñe todo el panorama del rock de los 80" (Pujol, 2007: 138).

\footnotetext{
${ }^{3}$ El punk como movimiento y como categorización rupturista significó, en términos de Paul Yonnet (1988), un espectacular retorno a las significaciones y las problemáticas propias de un presente complejo, como el vivenciado a mediados de la década del setenta en Gran Bretaña y en Estados Unidos. Así, cobraron valor las disputas en torno a la ciudad, sus objetos, la noche, el odio, la guerra y todo lo opuesto a los íconos pacifistas de los sesenta (Berti, 1994: 17).
} 
Sumado a esto, Rafael Gómez Pérez destaca que la inclusión de lo $p o p$, durante la década del 80 simbolizó, en primer lugar, un retorno a las tramas lúdicas de la cultura rock de la década del 60. En segunda instancia, se instauró una situación de "trivialidad", entablando relaciones con los sentidos humorísticos, sarcásticos, falsamente extravagantes y impostadamente ingenuos. En tercer término, el pop trajo a colación una idea de nuevas propuestas, provocando un afán de búsqueda e inspiraciones a partir del vínculo constante con lo popular y el coloquialismo. Como última característica, se remarca la dispersión por lo heteróclito de las propuestas artísticas de los artistas y agrupaciones (1994: 118).

\subsubsection{Los términos del new wave}

La orientación new wave se vinculó con una postura de fragmentaciones en géneros que atravesó fuertemente la situación del rock hacia finales de la década del 70 y principios de los 80 en el mundo de la música juvenil anglosajona. La estética funcionó como un factor primordial en las bandas new wave/pop: "cabellos cortos, ropas elegantes y cuidadas (de ahí la recuperación de aspectos como el $\bmod ^{4}$ de los años sesenta), pulcritud, vuelta d la corbata como signo distintivo y otros detalles menores" (Sierra I Fabra, 2003: 315).

En virtud de ello, convienen resaltar las contradicciones que trajo consigo el estilo pop en el rock porque, en su sentido más amplio, sirvió de contexto para que las concepciones de la posmodernidad lograran desarrollarse libremente en la década de los 70 y 80 en distintos puntos del mundo. En términos de Andreas Huyssen, durante los 60, el pop había representado en el arte un nuevo estilo de vida para las nuevas generaciones, que se rebelaba contra la autoridad y aspiraba a liberarse de las normas impuestas por la sociedad. En aquellos años, la idea del pop era integradora, y parecía suprimir la distancia del arte en relación con el resto del mundo y el resto de la experiencia.

Sin embargo, el arribo del pop produjo una eclosión en las dos últimas décadas del siglo

\footnotetext{
${ }^{4}$ Una subcultura de orientación modernista que se originó en Inglaterra y alcanzó su pináculo a principios de la década del 60. Los elementos significativos del movimiento incluían la moda y la música, como por ejemplo, el nuevo jazz, el soul afroamericano, el propio beat británico y el rhythm and blues norteamericano. La escena mod también fue asociada con el bailar toda la noche en las discotecas, avivado por la anfetamina.
} 
XX, puesto que "el arte se hizo profano, concreto y adecuado para la recepción masiva" (Huyssen, 2002: 249). De acuerdo con esto, los procuradores de la cultura rock (los músicos, los seguidores, la prensa especializada) sintetizó que el rock y el pop contemplaban ideas realmente irreconciliables: el pop servía como plan para la industria cultural y el negocio mercantil, mientras que las bandas de rock molestaban en las compañías porque resaltaban propósitos que subvertían el orden del mercado musical.

Al respecto, Chastagner remarca que el pop está doblemente inscripto en la cultura popular, debido a que se presenta como objeto y como comentario: "El pop hace visible y seductor el principio comercial gracias al lenguaje del mercado, y tiene a la vez una mirada crítica sobre este lenguaje y, por consiguiente, sobre este principio" (Chastagner, 2012: 109).

En consecuencia, la tendencia pop que aglutinó a distintos artistas durante la década del 80 dispuso un rock con lugares por explorar y con letras que exponían y dramatizaban los mecanismos del poder operantes en la vida cotidiana: "Estas bandas demostraban que 'lo personal es político' al diseccionar el consumismo, las relaciones sexuales, las nociones de sentido común acerca de qué es natural o normal y los modos en que las vivencias más espontáneas se hallan en realidad determinadas de antemano por fuerzas superiores" (Reynolds, 2013: 25). Del mismo modo, las letras empleadas capturaban el momento en el que "lo político es personal", construyendo así estrategias enunciativas que exponían cómo las acciones de gobierno pueden penetrar en la vida cotidiana y alterar las prácticas de los sujetos (2011: 39).

Los códigos del pop siempre se encuentran en disputa en el universo musical y se advierten sujetos a modificaciones, cambios y alteraciones. En función de la producción lírica en un marco de cultura rock, se señalan distintos modos de uso y de accionar en un proceso de connotación, sin dejar de ser denotativo. La narración de un discurso lírico de rock por medio de códigos pop se diferencia de otras posibilidades de narrar una historia: se busca representar a partir de denotaciones y se usan imágenes lingüísticas para abrir poéticamente los acontecimientos (Diederichsen, 2010).

Las canciones del pop-rock se vinculan con un efecto de fuerza de mercado (Frith, 2014), pero también revela fórmulas distintivas para expresar cambios en las costumbres sociales, concepciones románticas de la cotidianeidad, y patrones de conducta que se tensiones y/o se repelen para ocupar lugares en la sociedad. Las canciones, en formato pop, proponen un contraste entre versiones estandarizadas de la vida (el amor, el odio, la felicidad) y las complejidades de la existencia (individualismo, 
perspectiva apocalíptica, desazón).

\subsubsection{El rock argentino: escena, práctica y debate}

De acuerdo con lo antedicho, vale remarcar la importancia de la concepción del rock argentino como fenómeno cultural que ha adquirido desde sus inicios un carácter libertario y anti-autoritario que permiten pensarlo como un fenómeno preocupado por expresar un discurso con diferentes tonalidades de impugnación y crítica.

Desde su surgimiento, se lo considera uno de los pocos vehículos de la cultura que, de un modo artístico, se opuso a las dictaduras militares que padeció el país y se dedicó a sostener simbólicamente una identidad reprimida y sometida en distintos aspectos: la figura del joven (Pujol, 2005). Sin embargo, fue a partir de la década del 80 que el rock argentino generó expresiones con diferentes tipos de objetivos e inició un nuevo repertorio de manifestaciones que debió ser aprehendido rápidamente para mantenerse en el nuevo mercado.

Se comprende así que a partir de la recuperación democrática, los jóvenes revalorizaron los espacios públicos y privados, desde el ámbito de la cultura y abrazaron las instancias propuestas por un estado de reconfiguración democrática que se colocaba como símbolo de oposición al horror dictatorial. Así, las juventudes o los jóvenes de la pos-dictadura de los 80 abarajaron una situación distinta en torno a la política: se orientaron hacia la convivencia tensa con las otras generaciones (un tópico común en las juventudes) y asimismo, generaron discursos de revalorización y consolidación de la democracia (Kriger, 2013: 4).

Por ello mismo, a partir del advenimiento democrático, la juventud se ocupó de redefinir los debates acerca de la libertad y, consiguientemente, el rock argentino escoltó las cosmovisiones en torno a los valores democráticos. Tanto las visiones en torno a la recuperada democracia argentina como la memoria en relación con las atrocidades cometidas por la dictadura militar incidieron en los enfoques propuestos: la democracia contenía aires de libertad y el régimen se contemplaba como una amenaza y una sombra difícil de esquivar ${ }^{5}$.

\footnotetext{
${ }^{5}$ Esta relación entre rock, jóvenes y transición democrática se debe tener en cuenta en función de la incorporación a la vida política de una generación que tuvo proscripta la participación y a la censura que se inició a partir de la muerte de Juan Domingo Perón en 1974 y que se acentuó coercitivamente con el golpe cívico militar de 1976.
} 
Así, el panorama del rock argentino dejó entrever un momento de eclecticismo que trajo consigo diversas corrientes heterogéneas, como la llamada trova rosarina ${ }^{6}$ (relacionada con cierta perspectiva utópica en clave democrática), las vanguardias del punk, metal o reggae que tuvieron como denominador común el borde de la cultura hasta finales de la década del 80 y, por supuesto, la explosión de bandas new wave $e^{7}$ directamente pop (vinculadas con la cultura rock underground $^{8}$ que prosperaba al margen de la dictadura). En lo que respecta al rock argentino, los nuevos conceptos estéticos y estilísticos fueron incorporándose hasta copar las zonas más fértiles de la cultura rock. Las líricas del rock argentino, en clave pop, funcionaron como ejemplos de una retórica que proporcionaban palabras que existían para transmitir sentidos específicos de un sentir de época. Asimismo, el rock argentino se constituyó como una música bailable y, en algunas ocasiones, proponiendo un lirismo de enunciación irónica y paródica.

Sobre este punto, resulta importante resaltar el esquema de ciclos que retoma Berti y que se sustenta en los trabajos del periodista y escritor Miguel Grinberg, quien elabora cinco ciclos para comprender la clasificación histórica del rock argentino. A partir de ello, Berti destaca los desplazamientos discursivos del rock argentino desde sus inicios con el fin de diagramar las prioridades del movimiento durante la década del 80 :

\footnotetext{
${ }^{6}$ Con este nombre se identifica a la generación de músicos de la ciudad de Rosario, surgida a comienzos de la década de 1980. El movimiento se caracterizó por vincular el rock, el tango y el folklore con líricas poéticas y narrativas con intenciones netamente literarias. Entre los músicos más destacados se encuentran Fito Páez, Juan Carlos Baglietto, Jorge Fandermole, Silvina Garré, Adrián Abonizio, Fabián Gallardo, Rubén Goldin, Lalo de los Santos, Ethel Koffman, entre otros.

${ }^{7}$ Este término nació hacia finales de la década del 70, luego de la irrupción del punk en Gran Bretaña y en Estados Unidos. Este concepto se emplea para definir a un género musical que refiere a las "nuevas olas" de músicos/artistas/bandas que surgieron como alternativa a las tendencias hippies, sinfónicoprogresivas y punks (aunque mantengan una relación social estética y discursiva con estos últimos y con los llamados mods de la década del 60, cuyo máximo representante fue la banda The Who). El new wave amplió los límites del rock, uniendo influencias y anunciando los rasgos específicos del rock de los 80 que, en lo que concierne al discurso, se orientó hacia las fragmentaciones textuales, los eslóganes, el tono burlesco y las parodias.

${ }^{8}$ El llamado underground es, como su mismo nombre lo indica, un movimiento subterráneo que se desarrolla al margen de la industria discográfica, publicitaria y cultural que convierte a las bandas, sus discos y sus canciones en productos de consumo masivo.
} 


\begin{tabular}{|c|c|c|c|c|}
\hline Ciclo & Años & $\begin{array}{c}\text { Artistas } \\
\text { representativos }\end{array}$ & Empleo de la persona & $\begin{array}{c}\text { Canciones } \\
\text { emblemáticas } \\
\text { de la etapa }\end{array}$ \\
\hline Ciclo I & $\begin{array}{l}\text { Desde } 1966 \text { hasta } 1970 . \\
\text { La elección tiene que ver } \\
\text { con la fundación y la } \\
\text { separación correspondiente } \\
\text { de dichas bandas. }\end{array}$ & $\begin{array}{lr}\text { Los } & \text { Gatos, } \\
\text { Manal } & \text { y } \\
\text { Almendra. } & \\
\text { Sumado a } & \text { la } \\
\text { aparición } & \text { de } \\
\text { Moris, } & \text { Vox } \\
\text { Dei, } & \text { Los } \\
\text { Abuelos de } & \text { la } \\
\text { Nada } & \text { y } \\
\text { Tanguito. } & \end{array}$ & $\begin{array}{l}\text { Utilización de la segunda } \\
\text { persona: tú }\end{array}$ & $\begin{array}{l}\text { "Rebelde" (Los } \\
\text { Beatniks, 1966), } \\
\text { "La balsa" (Los } \\
\text { Gatos, 1967), } \\
\text { "Diana Divaga" } \\
\text { (Los Abuelos de } \\
\text { la Nada, 1968), } \\
\text { "Muchacha ojos } \\
\text { de Papel", } \\
\text { (Almendra, } \\
\text { 1969), "Jugo de } \\
\text { tomate frío" } \\
\text { (Manal, 1970), } \\
\text { "El oso" (Moris, } \\
\text { 1970). } \\
\text { "Presente" (Vox } \\
\text { Dei, 1970). }\end{array}$ \\
\hline Ciclo II & $\begin{array}{l}\text { Desde } 1971 \text { hasta } 1976 . \\
\text { Se toma como punto final } \\
\text { la disolución del grupo Sui } \\
\text { Generis, la instauración de } \\
\text { la dictadura cívico militar y } \\
\text { la conclusión de la banda } \\
\text { Invisible, de Luís Alberto } \\
\text { Spinetta. }\end{array}$ & $\begin{array}{l}\text { Bandas: } \\
\text { Pappo's Blues, } \\
\text { Pescado } \\
\text { Rabioso, Color } \\
\text { Humano, } \\
\text { Aquelarre, } \\
\text { Pedro y Pablo, } \\
\text { Sui Generis, } \\
\text { Billy Bond y la } \\
\text { Pesada } \quad \text { del } \\
\text { Rock and roll, } \\
\text { Invisible, entre } \\
\text { otros. }\end{array}$ & $\begin{array}{l}\text { Utilización de la segunda } \\
\text { persona: vos. Lenguaje } \\
\text { coloquial, juvenil } \\
\text { y callejero. }\end{array}$ & 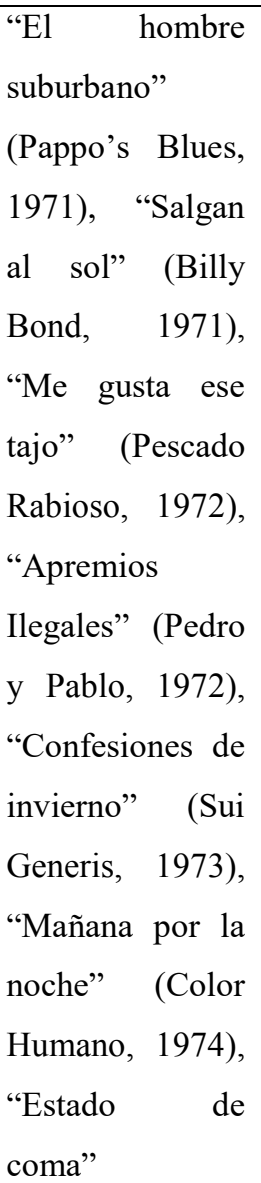 \\
\hline
\end{tabular}




\begin{tabular}{|c|c|c|c|c|}
\hline & & & & $\begin{array}{l}\text { (Invisible, } \\
\text { 1974), } \\
\text { "Violencia en el } \\
\text { parque" } \\
\text { (Aquelarre, } \\
\text { 1974). }\end{array}$ \\
\hline Ciclo III & $\begin{array}{l}\text { Desde } 1976 \text { hasta } 1982 . \\
\text { Período que abarca el inicio } \\
\text { de la dictadura cívico } \\
\text { militar y el final de la } \\
\text { guerra de Malvinas. }\end{array}$ & $\begin{array}{l}\text { La máquina de } \\
\text { hacer pájaros, } \\
\text { Seru Girán, } \\
\text { León Gieco, } \\
\text { Luís Alberto } \\
\text { Spinetta, Raúl } \\
\text { Porchetto, entre } \\
\text { otros. }\end{array}$ & $\begin{array}{l}\text { Empleo de la primera } \\
\text { persona del plural: } \\
\text { nosotros. El uso del } \\
\text { nosotros inclusivo } \\
\text { consideraba al público y } \\
\text { no integraba únicamente a } \\
\text { los músicos. Funcionaba, } \\
\text { en este caso, como un } \\
\text { nosotros que excluía a la } \\
\text { dictadura militar y a los } \\
\text { dirigentes políticos. La } \\
\text { alegoría servía como } \\
\text { recurso para subrayar esa } \\
\text { exclusión y burlar así la } \\
\text { censura. }\end{array}$ & $\begin{array}{l}\text { "Qué se puede } \\
\text { hacer salvo ver } \\
\text { películas" (La } \\
\text { máquina de } \\
\text { hacer pájaros, } \\
\text { 1977), "Canción } \\
\text { para los días de } \\
\text { la vida" } \\
\text { (Spinetta, 1977), } \\
\text { "Solo le pido a } \\
\text { Dios" (León } \\
\text { Gieco, 1978), } \\
\text { "Seminare", "La } \\
\text { grasa de las } \\
\text { capitales", } \\
\text { "Canción de } \\
\text { Alicia en el } \\
\text { país”, } \\
\text { "Peperina” (Serú } \\
\text { Girán, } \\
\text { 1978/79/80/81), } \\
\text { "Algo de Paz" } \\
\text { (Raúl Porchetto, } \\
\text { 1980). }\end{array}$ \\
\hline Ciclo IV & $\begin{array}{l}\text { Desde } 1982 \text { hasta } 1985 . \\
\text { Es la etapa posterior a la } \\
\text { derrota de la guerra de } \\
\text { Malvinas y el año de la } \\
\text { consagración nacional y } \\
\text { exportación masiva del } \\
\text { rock argentino. En } 1985 \text { no } \\
\text { editan ningún álbum ni } \\
\text { García ni Spinetta, por }\end{array}$ & $\begin{array}{l}\text { Charly García, } \\
\text { Virus, Zas, } \\
\text { Sumo, Los } \\
\text { Abuelos de la } \\
\text { Nada (segunda } \\
\text { formación), } \\
\text { Soda Stereo, } \\
\text { Alejandro } \\
\text { Lerner, GIT, La }\end{array}$ & $\begin{array}{l}\text { Utilización de la primera } \\
\text { persona: } y o \text {. } \\
\text { Empleo de la } \\
\text { fragmentación }\end{array}$ & $\begin{array}{l}\text { "Yendo de la } \\
\text { cama al living" } \\
\text { (Charly García, } \\
\text { 1982), "Todo a } \\
\text { pulmón" } \\
\text { (Alejandro } \\
\text { Lerner, 1983), } \\
\text { "Mil Horas" } \\
\text { (Loa abuelos de }\end{array}$ \\
\hline
\end{tabular}




\begin{tabular}{|c|c|c|c|c|}
\hline & primera vez desde 1970. & $\begin{array}{l}\text { Torre, Los } \\
\text { Twist, Los } \\
\text { Encargados, } \\
\text { Sueter, Viudas } \\
\text { e Hijas de } \\
\text { Roque Enroll, } \\
\text { Los Enanitos } \\
\text { Verdes, Celeste } \\
\text { Carballo, Fito } \\
\text { Páez, entre } \\
\text { otros. }\end{array}$ & & 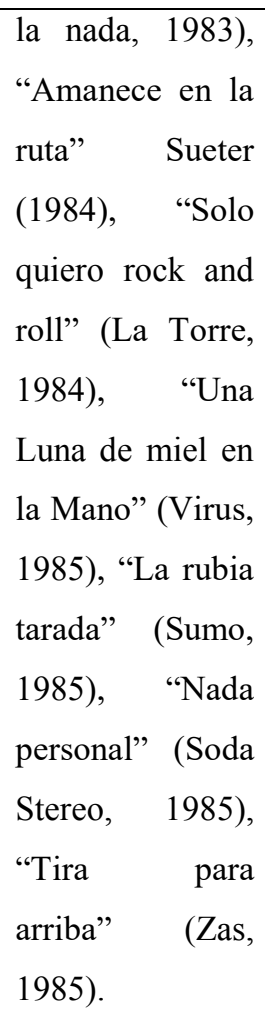 \\
\hline Ciclo V & $\begin{array}{l}\text { Desde } 1986 \text { hasta } 1989 . \\
\text { Estos años abrieron un arco } \\
\text { que se extendió desde la } \\
\text { crisis económica y política } \\
\text { del gobierno de Alfonsín } \\
\text { hasta la asunción del ex } \\
\text { presidente Carlos Menem. }\end{array}$ & 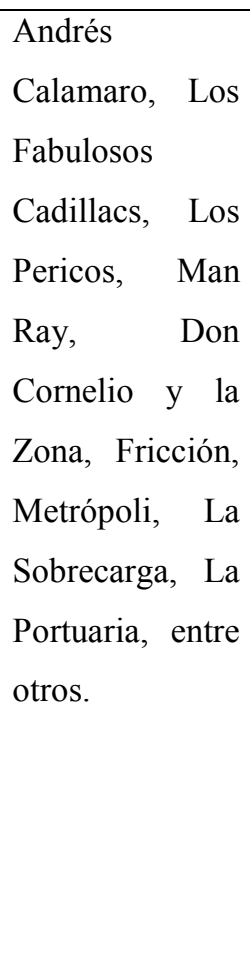 & $\begin{array}{l}\text { Profundización de la } \\
\text { primera persona: yo }\end{array}$ & 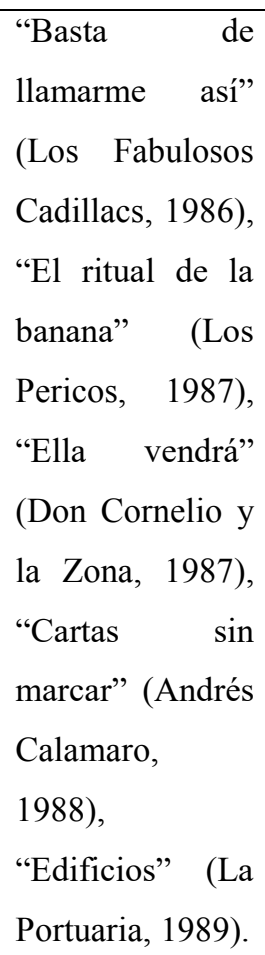 \\
\hline
\end{tabular}

El pop, para los rockeros de la década 70 (exceptuando a Charly García, Miguel Abuelo y Miguel Cantilo), funcionaba como sinónimo de banalidad o artificio. No obstante ello, el pop, como concepto e idea, consolidó una simbología de canción, con todos sus atributos: el ritmo, la melodía, la armonía, la frescura y la espontaneidad. Con estos 
elementos, la cultura rock argentino se nutrió del pop para "amoldar" su lenguaje contestatario (Cibeira, 1985).

El rock y el pop confluyeron en el ámbito del denominado underground metropolitano, produciendo así encuentros en circuitos no convencionales. En los últimos años de la dictadura, el "Bar Einstein" de Omar Chabán y "Zero Bar", "El Corralón” y "Stud Free Pub", por ejemplo, se convirtieron en centros artísticos en el que se manifestaban distintas cosmovisiones estéticas:

La década del 80 tenía, antes de Malvinas, una especie de efervescencia en los sótanos. Había gente de clase media y media alta que era muy consciente de lo que ocurría en el rock nacional y que trajo, en un país totalmente cerrado, como fue el país de la dictadura, novedades de lo que ocurría en Estados Unidos y en Inglaterra. Entonces se dio la gran renovación del rock, gente que empezó a escuchar música New Wave, Ska, Punk (...) Fue la gran renovación del rock y la gran pérdida de la inocencia (Del Mazo, 2006: 41-42).

En relación con el contenido de las letras de las bandas que surgían y de los artistas que conservaban su éxito y su credibilidad, cabe destacar que se advertía una intención más contestataria hacia el régimen, vinculada con el contexto de desgaste dictatorial y con los cánticos del propio público.

Teniendo en cuenta dicho escenario de complejidad conceptual, la tesis señala la tensión que trajo consigo la concepción del rock argentino, en clave pop, a partir de las construcciones discursivas de la libertad y sus vínculos con el contexto de advenimiento democrático. En función de ello, las tramas discursivas de las líricas atraviesan debates que se interrelacionan y colocan en cuestión polémicas que resaltan las articulaciones entre la cultura rock y la irrupción del pop.

\subsubsection{Rock argentino y relación pop}

A partir de 1981, el rock argentino se destacó por generar espacios marginales y suburbanos que abordaban estéticas diversas de creación artística en tiempos dictatoriales. Se avalaban así estilos y discursos líricos rupturistas en vínculo directo con la irrupción del género punk (coronado durante los años 1976-1978) y el denominado post-punk (célebre durante los años 1979-1981). Este estallido cultural 
trajo aparejados cambios estéticos que provocaron un cimbronazo en los estamentos suburbanos del rock argentino. Dicho advenimiento provocó, además, una fractura en la tonalidad monocorde, discursiva y sonora del rock argentino.

En este aspecto, las estrategias enunciativas de las líricas se vincularon con formas alegóricas, irónicas y sarcásticas vinculadas con un discurso fragmentario e inconexo. En paralelo con esta situación controvertida, el rock vivenció un retorno al underground (por fuera de los carriles que la industria delimitó entre los años 1967-1981) y forjó un territorio suburbano y periférico que acuñó a una gran parte del rock masivo de la democracia.

Así, la corriente underground del rock argentino pre-democrático se conformó como una usina cultural que planteó de una manera distinta el consumo del rock. Los músicos no mostraban intenciones de rendirle tributo al pasado y pretendían integrarse a la cultura de masas, con las ventajas y los problemas del caso. De esta manera, salieron a la luz bandas con nuevos valores que en poco tiempo fueron partícipes elementales de la historia del rock argentino: Virus, Soda Stereo, Patricio Rey y sus Redonditos de Ricota, Sumo, GIT, Zas, Los Twist y Los Abuelos de la Nada (segunda formación), entre otros.

Sobre este punto, el investigador Pablo Alabarces remarca que el rock argentino planteó un juego de fuerzas que forjó una gesta anti-represiva en los recitales (cada vez más masivos) e impidió, mínimamente, que se desentramara la "desideologización flagrante" impuesta por el proceso: "Los públicos (...) no podían articular otro discurso que el "se va a acabar, la dictaduras militar". Nuevamente, se trataba de un énfasis ético antes que político sitricto sensu, pero en esa vaguedad se revelaba eficaz e interpelador" (2008: 39).

Del mismo modo, los periodistas Eduardo De la Puente y Darío Quintana, sostienen que el ingreso de un nuevo público posibilitó una apertura en cuanto a temática y tratamiento de las líricas, y también generó un drástico cambio de actitud en la estrategia de enunciación: "Política, guerra, desaparecidos, droga, homosexualidad son ítems tomados con gravedad en determinadas ocasiones, con humor y desenfado en otras, evidenciando un notable contraste con el silencio reinante en la mayor parte del período anterior". (1996: 126).

Ante esto, y en un contexto de alta rotación mediática sumada a la efervescencia participativa de gran parte de la sociedad, Alabarces señala que el rock se introdujo en los mecanismos de la cultura de masas, "perdiendo contenido político y ganando 
autorreferencia y pastiche, hasta derivar en un péndulo entre una suerte de anarquismo descomprometido y un pasatismo paródico" (2008: 40).

Sobre este último punto, la situación es discutible porque en primera instancia, toda intervención artística tiene contenido o búsqueda política (por más cercanía o lejanía que se tenga con las concepciones antropológicas, clasistas o estructurales de la sociedad). En segundo término, se puede colocar en cuestión el supuesto desacuerdo político o apolítico de las letras desde otro lugar: las líricas producidas durante el período 1982-1989 no estaban despojadas de la política.

Los artistas, en su gran mayoría, provocaban un discurso de tono más dispar o suavizado que se encontraba conmovido por la perspectiva política oficialista $\mathrm{y} / \mathrm{o}$ alfonsinista y que se sostenía en una perspectiva a favor de la reflexión sobre los derechos humanos y se separaba del ideal revolucionario-político de la década del 70. Decididamente, es posible advertir que la postura ganaba complejidad en teorías que apuntaban hacia un final de las ideologías o, en gran medida, hacia una suspensión de conflictos que simulaba afinidades sociales. Esto es sumamente político y aún se encuentra relegado por los historiadores, los críticos y los estudiosos del rock. En este sentido, es de destacar la indefinición en la que se sumergió el rock durante el período mencionado y conviene pensar sus complejidades (poco reveladas o interpretadas en su máxima expresión).

\subsubsection{Identidad corporal}

De acuerdo con lo manifestado por Pujol, las canciones que otrora habían manifestado instancias colectivas y hasta aguerridas, le estaban dejando lugar a las concepciones hedonistas: "Despuntaban esos peinados nuevos anunciados por Charly. De la sociedad al cuerpo, de lo colectivo a lo privado: una nueva subjetividad iba cobrando forma en el repertorio de un rock que, no bien transcurrida la ruptura punk, parecía sentirse a gusto bajo la piel del pop" (2010: 334).

Los discursos del rock argentino construyeron un particular sentido de identidad mediante experiencias y procesos experienciales de reconstrucción democrática: las canciones crearon autodefiniciones particulares, proporcionaron una vía para administrar la vida emocional pública y privada, dieron forma a la memoria colectiva que, de acuerdo con Frith, organiza nuestro sentido del tiempo y promulgaron una “situación” que se posee (1987: 2). 
El rock argentino, haciéndose eco del contexto de destape o del desprejuicio generalizado en torno a los tabúes luego del horror y el silenciamiento forzoso, incorporó temáticas que nunca habían figurado abiertamente en su repertorio y se encargó de reivindicar la dimensión física y erótica de la vida. La tematización del placer se colocó en el tapete. El sujeto aparecía como alguien que tenía un compromiso liberal en la vida que significaba un camino hacia la transformación.

La música pop argentina de los años 80 presenta características similares a las descriptas por Richar Dyer en "Defensa del disco". Si bien Dyer desarrolla el erotismo, el romanticismo y el materialismo de la cultura disco en la cultura gay/lesbian americana, en el caso argentino no se restringe sólo a la cultura gay si bien grupos emblemáticos como Virus y Los abuelos de la nada son íconos gay. El pop incorpora en este lenguaje queer a un movimiento contracultural que reconoce la discriminación sexual y racial como elementos constitutivos de la estructura de clase y género capitalista (Garrote, 2006).

La postura sexual y erótica emergió de los discursos del rock argentino a partir de una particular conceptualización de la libertad, entronizada desde el cuerpo y, también, las nuevas representaciones de los géneros. Así, se profundizó una relación entre rock, deseo y placer que permitió marcar una diferencia notable para inscribir en la superficie de la realidad social una línea divisoria entre un ellos y un nosotros (Grossberg, 1984: 234).

En este sentido, el pop, desde la óptica de la cultura rock, se enunció a partir del dolor y los retos del amor, sumando así un discurso de erotismo y excitación. De este modo, la orientación y la invitación al baile o la incitación corporal se tomó como una manera de invocar y provocar el sentimiento sexual y la intimidad: "El foco puesto en la intimidad reflejó no solo un contexto de negociaciones en el que el deseo sexual (...) La mejor música pop registraba los problemas que implicaba mantener ese ethos, especialmente en una sociedad cada vez más consumista y hedonista” (Hesmondhalgh, 2015: 112).

\subsubsection{Rock argentino: entre la autenticidad y decisión comercial}

Las perspectivas que abordaron una ética comercial e industrial durante la década del 80 se situaron en vínculo directo con la pretendida ética no comercial, subterránea y 
marginal del rock argentino de la década del 70. Alabarces, en esta instancia, sostiene que el eje comercial-no comercial se configura como el núcleo sustancial por excelencia en el rock: venderse o no venderse, transar o no transar con el mercado se aprecia como un mito y se constituye un gesto resistente en la cultura rock argentina, por ello, "ciertos sonidos, ciertas ecualizaciones" dejaron "de ser juzgadas estéticamente para ser condenadas éticamente" (2008: 41).

$\mathrm{Al}$ respecto, Berti señala que la década hizo evidente la división de aguas presente en el rock argentino, puesto que la diatriba diferenciaba a los que rescataban una postura opositora hacia el sistema de los que desdeñaban perspectivas históricas o negaban dicotomías supuestamente superadas (derecha-izquierda-oposición de clases, de generación, de sexo), en provecho de lo indiferenciado y aleatorio (Berti, 1994: 86).

Asimismo, cabe señalar que la sociedad de masas funciona como un escenario en el que se libra el enfrentamiento entre lo comercial y lo auténtico. Por ello mismo, el investigador David García destaca que estos dos estadios son diferentes en el proceso, contradictorios y relacionales. En este punto es necesario hacer explícita la perspectiva de las industrias culturales y comprender cómo el sello de distinción de lo underground emana de la negación u oposición a la lógica comercial que les es inherente (2009: 12). Se proponen así, entonces, dos vertientes en pugna: en primer lugar, los que reflexionaban desde las antípodas de la industria cultural del rock, reivindicando la producción independiente y enfrentándose al rock comercializado y, en segundo lugar, los exponentes del rock de la democracia que pretendían aprovechar de la mejor manera la apertura del mercado discográfico y se preocupaban por popularizar su imagen y generar enlaces con la industria discográfica y/o mediática (Correa, 2002: 47). Se requería, de esta manera, la dimensión corporal y el baile como algo tradicionalmente olvidado por la corriente principal del rock argentino.

Hacia la década del 80, la divulgación masiva y la alta rotación de canciones rockeras colocó en crisis la noción de movimiento que tenía el rock argentino desde 1967 (año de edición de "La Balsa" de Los Gatos). A partir de allí, sobresalieron las diferencias estéticas, estilísticas y políticas de los artistas y de sus líricas.

Durante el período remarcado, el concepto de la libertad cobró importancia por su divergencia y por su notoriedad en vínculo directo con la conceptualización de subcultura. El término de subcultura, en este caso, se alejó de la idea de comunidad o movimiento homogéneo y propuso disputas y marcos de discusión en el seno del rock argentino de la década. La idea de comunidad se había contemplado hegemónicamente 
durante los años 1967-1980, pero se acomplejó en el tiempo a raíz de la propia contradicción planteada por el rock en relación con el sistema o lo político.

Al respecto, Miguel Grinberg estableció tres matices discutibles que atravesaron la singularidad del movimiento antes de la guerra de Malvinas: se erigió a partir de una heterogeneidad de confluencias particulares y con distinciones de "a-movimiento"; se instituyó a partir de la resistencia a todo tipo de institucionalización gubernamental o imposición de las reglas de mercado; se caracterizó por propagar una apología de la pureza y de crudeza en relación con lo comercial y lo no-comercial (1985: 150).

En contraposición con esta postura, Alabarces señala que Grinberg colaboró con los desvaríos y contradicciones del rock argentino, más precisamente, en relación con lo comercial, lo no comercial y las creaciones imposibles por fuera del mercado (1993: 46). Dejando de lado la idea de movimiento o comunidad, Alabarces señala que en tiempos de dictadura cívico-militar, el rock argentino suspendió disputas en virtud de una estética defensiva (pasiva) y ofreció una homogeneización imaginaria (1993: 83).

Como se mencionó entonces, la crisis de la noción de movimiento o comunidad se desarrolló profundamente a partir de la finalización de la guerra de Malvinas en vínculo directo con la fragmentación de estilos y modos de abordar lirismos. Tanto es así que en ese período se multiplicaron las interpelaciones sociales y políticas dirigidas a los jóvenes (Semán y Vila, 1999: 238) y aparecieron representaciones sociales que atravesaron interpelaciones apropiadas para los jóvenes urbanos de un proceso de reconstrucción democrática.

Igualmente, durante el advenimiento democrático, el rock argentino comenzó a perder su rol de sostén de la identidad joven durante la dictadura a partir de la reaparición de los partidos políticos, la organización de los movimientos de derechos humanos y/o sindicatos. De este modo, el rock vernáculo se enmarcó en un proceso de transformación de construcción de sentido y modificó el manto protector de las variantes estilísticas: la mínima cohesión estética del movimiento, generó, a partir de ello, mayor diversidad de narrativas y apreciaciones juveniles.

Las virtudes de los discursos que atraviesan la propia conceptualización auténtica de la cultura rock generaron también un proceso de búsqueda de libertades que supieron colocar en cuestión los mapas simulados de ciertos discursos políticos, controversiales y modernos frente a los destacados procesos en un tramo de reconstrucción democrática. En lo que concierne al rock argentino, la preocupación por la autenticidad cobró narrativas interesantes durante la década del 80 porque trazó líneas divisorias a partir de 
la incidencia comercial. Así, comenzaron a establecerse fronteras que separaron al rock y al pop o que, más bien, lo distinguieron en sus versiones. El debate en sí, trajo aparejado interrogantes que desacralizaron el rigor tajante de "la autenticidad", lo reformularon y lo llevaron a un tono simulado o de "simulacro" que profundizó discursos desde la ambigüedad.

\subsection{Jóvenes}

La juventud se ocupa de redefinir los debates acerca de la libertad y, del mismo modo, remueve las cosmovisiones de los jóvenes en marcos temporales diversos. En lo que refiere a la construcción de la democracia argentina, la perspectiva de la juventud incidió en las visiones de convivencia y defensa del estado de derechos. Frente a esto, la dictadura se presentó, a partir de 1983, como una amenaza y una sombra difícil de esquivar. De manera particular, el rock argentino se manifestó como un nodo cultural primordial para comprender los modos de pensar las libertades de los jóvenes.

La cuestión de los jóvenes, la juventud y/o las juventudes es una construcción histórica, social y conceptual que admite transformaciones en los códigos de la cultura y significaciones en las costumbres y en lo que refiere a las luchas de generaciones anteriores. En función de ello, forma parte de distintos paradigmas en la actual democracia argentina $\mathrm{y}$ ha sido atravesado por nociones, pensamientos, modas $\mathrm{y}$ modelos que trataron de interpretarlo e identificarlo.

La juventud como concepto se conformó en tópico y objeto de estudio en plena etapa de imposición globalizante y sobre todo en una época de crisis, a partir del triunfo del mercado sobre las soberanías e identidades nacionales (Kriger, 2010). Así, la conceptualización de juventud o de juventudes nació en el tránsito de politización/despolitización $\mathrm{y}$, teniendo en cuenta el caso de los estados latinoamericanos, se vinculó con el advenimiento democrático y el inicio de una dinámica social histórica, continua y heterogénea.

La juventud implica una vanguardia de transformaciones en los códigos de la cultura e incorpora así sensibilidades, percepciones, concepciones temporales, valorizaciones, velocidades e incomodidades. En términos de Mario Margulis, los jóvenes ponen de manifiesto con más intensidad y variedades que otras generaciones los cambios culturales, las nuevas modalidades y los apetitos de la identidad (1996: 10). 
En virtud de la categoría de los jóvenes, la mirada de la investigadora Florencia Saintout resulta particular, puesto que destaca la polisemia que transporta el concepto. La categoría jóvenes admite heterogeneidades: ofrece distintas modos de inserción en la estructura social, instituye distintas formas de ser concebida y revitaliza diversos modos de acción y de conducta.

La juventud se conforma, desde esta última perspectiva, a partir de la noción de lo colectivo, con múltiples modos de ser y sentir. Los jóvenes se muestran atravesados por sucesos socio-históricos que los particulariza y los ubica en una dialéctica que los interpela como generación. Este último término contiene, en su concepción, las incidencias históricas, políticas, sociales, tecnológicas y culturales de una temporalidad en la que se advierte la aparición de una nueva cohorte en la sociedad:

\begin{abstract}
Para hablar de los jóvenes es necesario saltar de una mirada que se basa únicamente en la cuestión etarea hacia cómo es que el dato biológico se encuentra cargado social y culturalmente, lo que permite pensar en distintos jóvenes. La condición de juventud no se ofrece de igual forma al conjunto de los integrantes de la categoría estadística joven. Por el contrario, existen diferentes y desiguales modos de ser joven, que marcarán distintos modos de percibir el mundo (Saintout,
\end{abstract} 2006: 23).

De acuerdo con la investigadora Rossana Viñas, no existe un único modo de concebir el concepto de joven y que, asimismo, sus prácticas no han sido las mismas en cada época. Las visiones del mundo que se esgrimen están conformadas desde un particular lugar dentro de un espacio social y cultural determinado (2014: 60). La juventud, indudablemente, se ocupa de redefinir los debates acerca de la libertad en cada contexto y, del mismo modo, remueve las cosmovisiones de lo/as jóvenes. En función de ello, los jóvenes articulan sus comunidades de sentido con sus pares en sus colectivos. Su construcción implica la relación con los otros y con el mundo con el objeto de afirmarse como sujetos en sociedad (Reguillo, 2000: 57).

\title{
2. 6.1. La concepción de subculturas
}

La categoría de culturas juveniles refiere a la manera en que las experiencias sociales de los jóvenes se expresan de un modo colectivo, a partir de construcciones sociales, 
estilos de vida y espacios tensionantes de la vida institucional. Siguiendo las propuestas de Carles Feixa, se entiende que la noción de culturas juveniles remite a una noción de culturas subalternas y que, en la tradición gramsciana, son consideradas desde su dominación y su precaria (paulatina, sesgada) integración en la cultura hegemónica (1998: 85).

El reconocimiento de una territorialidad y de un espacio de disputa resulta fundamental para comprender la disposición de las subculturas juveniles. La territorialidad, por tanto, no es sólo una manera mediante la cual los jóvenes viven la subcultura como un comportamiento colectivo, sino la manera en que la subcultura se enraíza en sociedad (Cohen, 1972: 26-27). El concepto de subcultura, en virtud de lo expuesto, construye tensiones con el conservadurismo, la cultura burguesa dominante y las sociedades castradoras.

En la clave teórica de Dick Hebdige y de los estudios culturales ingleses, las subculturas son formas expresivas que exponen una tensión fundamental "entre quienes ocupan el poder y quienes están condenados a posiciones subordinadas y a vidas de segunda clase. Esa tensión se expresa figurativamente en forma de estilo subcultural” (1979: 180). La evolución de la subcultura se asocia a menudo a tendencias musicales y al uso selectivo y creativo de la música, que escuchan en la radio, en su propia habitación o con la presencia en recitales. Siguiendo a Feixa, la emergencia de las culturas juveniles está asociada al nacimiento de la cultura rock, es decir, el primer gran campo simbólico de la estética generacional. El rock se encuentra integrado en el imaginario de la cultura juvenil: se advierten, al menos provisoriamente, modismos, intereses e identificaciones que interpelan de un modo directo. A partir de esta puesta en común, la música es utilizada por los jóvenes como un medio de autodefinición, un emblema para marcar la identidad (Feixa, 1998: 101).

En consecuencia, el significado de la subcultura plantea un estado de disputa, desde las coordenadas juveniles, y admite discusiones sobre las posturas estéticas y los estilos. Los estilos integran las posiciones subculturales y en sus prácticas es posible leer tensiones entre dominantes y sometidos o dependientes. Los estilos, como el pop en la perspectiva de la cultura rock, provocan debates y pueden ser repudiados, ignorados o situados, también pueden comprenderse como intimidaciones que atentan contra la organización social, el status quo o directamente, como manifestaciones inofensivas de la juventud. No obstante, se puede remarcar que los estilos y las estéticas de las jóvenes, 
pensadas desde una situación subcultural, expresan tensiones en torno a las formas instituyentes.

\subsubsection{Cultura rock y tensiones juveniles}

La idea de las tensiones conceptualiza lo juvenil y también supone el reconocimiento de las relaciones de poder y la dominación social. El interrogante de las tensiones admite la complejidad de las prácticas de los jóvenes y su rol activo en la sociedad que los convoca. Por consiguiente, el terminó que incluye a la tensión como concepto permite comprender la interpelación juvenil hacia los aspectos conservadores de los contextos. De esta forma, la integración de la conflictiva tensión entre la política, lo cultural y lo político se advierte como una relación que instituye permanentemente lo social, entendido como mundo común con densidad histórica y potencia proyectiva (Kriger, 2010: 44).

Esta última conceptualización funciona como un distintivo totalizador que contiene características de rebeldía y crítica desde su puesta en acción. La tensión complejiza la relación con la industria cultural, puesto que coloca en crisis la combinación, fomenta un desacuerdo y trastoca el pensamiento resignado con la intención de proponer un sentido esperanzador.

El discurso de la cultura rock siempre se ha focalizado en las vivencias de los jóvenes y ha afrontado así su cotidianeidad, sus discusiones, sus perspectivas, sus rudimentos, sus pasiones y amores. Es decir que existe cierta cuestión en la que músicos o compositores jóvenes le hablan, le escriben y le cantan a escuchas jóvenes (y lo postulan, sobre todo). Es un discurso de constante resignificación, dialéctico y bidireccional en cuanto al contexto y al discurso de las propias líricas de las bandas.

La cultura rock plantea un modo de no estar solos y se coloca como un medio de comunicación infalible (repleto de ruidos y vertientes de conflicto) en el que los jóvenes encuentran interpelaciones. Se introducen así un vértigo que integra estimulaciones sexuales y sensoriales, a partir del empleo de drogas, alcohol y otros motivos de experiencia. Si bien, la estridencias de esta cultura han ido anexándose progresivamente a la cultura oficial, se han habilitan también lugares de tensión y disconformidad que permiten una activación de hendijas críticas, propias de las experiencias juveniles. De esta manera, el rock reúne dos tendencias relevantes: "la posibilidad de fuga hacia los márgenes de lo impensable, y las líneas de recomposición y re-funcionalización de los 
focos subversivos o dispersos" (Pérez Islas, 1998: 49).

La cultura rock generó así un propio mercado, integrado por códigos sociales e interpersonales que abrieron un espacio para los jóvenes y los adolescentes, desde mediados de la década del 50 hasta la actualidad. Puede interpretarse que existe una operación política muy dinámica que admite, primordialmente, "una representación colectiva, impregnada por diferentes vivencias por parte del público y que posteriormente se plasmó en espacios sociales concretos como los estadios y teatros donde se realizan los recitales" (Giberti, 1998: 179).

\section{6.3. El rock argentino y la pregunta juvenil}

El rock en la Argentina ha funcionado históricamente como motor cultural que intentó estar en compañía del joven o de acompañar su significado para vincularlo con conocimientos de libertad y rebeldía (cuando no, con la simbolización de la revuelta o, más exageradamente, con los aspectos revolucionarios de una sociedad).

La década del 60 había permitido el surgimiento de la juventud en tanto actor político y social. Se pudo constituir así un sujeto colectivo que motorizaba los cambios, que hacía de la rebeldía su estandarte, que encarnaba los nuevos aires de la época y anunciaba, desafiante y segura (Carnovale, 2013: 6). De esta manera, el advenimiento inminente de lo nuevo permitió manifestaciones de elementos comunes que caracterizaron la época: la posibilidad de la utopía, la rebeldía, la búsqueda la creatividad y la novedad, el cuestionamiento de los poderes instituidos y de los conservadurismos burgueses, la lucha contra la opresión, los autoritarismos y los convencionalismos. De ahí que las ideas de "liberación” y de "vanguardia" inundaran el lenguaje de la política, del arte, de las costumbres (Carnovale, 2013: 3).

En referencia al vínculo cultural e íntimo con la idea de transformación propia de la década del 60 es de destacar que a partir de la llegada de la democracia dichas líricas celebraron una alianza paradigmática entre el rock, la celebración del cuerpo joven y la representación de los géneros. La noción del "yo libre" de los jóvenes de los 60 se caracterizaba por su espíritu contestatario, libertario y vanguardista que rechazaba tonalidades conservadoras y convencionales (Manzano, 2010: 384).

La respuesta cultural fue tomada en parte por el rock pop argentino del período posdictatorial porque contrastaba con el crítico pasado de terrorismo de estado: los cambios estructurales de la sociedad colocaron en crisis la integración y participación social- 
política, el acceso al desempleo, las dificultades educativas y de salud, entre otras (Szulik y Kuasñosky, 1996: 225).

Por otra parte, es posible pensar que se compuso una relación de cambio principal con la voluntad militante de los jóvenes de la década del 70 a partir de lecturas y claves incluidas en otro contexto, más orientada hacia el rol activo de la juventud, en vínculo directo con la toma de decisiones en la vida ciudadana, más que desde la militancia política. La nueva configuración social del país pos-dictatorial permitió forjar una revalorización del rol activo de los jóvenes y de los oyentes de rock en particular, conforme a la participación de gran parte de la sociedad en la reaparición y el desarrollo de la ansiada democracia.

En esta instancia, conviene precisar la alianza entre el rock, la celebración del cuerpo y la representación de los géneros que se anunció en párrafos anteriores porque marcó una diferencia en torno a las movilidades sexuales de la década del 70 (y también la del 60). Durante la década del 70, la figura del joven rebelde y la del militante revolucionario contemplaba un proceso de transformación poco explorado: la irreverencia devenía en solemnidad, la rebeldía en disciplina y el "amor libre" en moral revolucionaria (Carnovale, 2013: 8).

Coincidiendo con Pablo Vila, el rock argentino desempeñó un papel importante en la socialización y la re-socialización de los jóvenes que en plena dictadura cívico militar asistieron al derrumbe de sus derechos (1985: 62). Para ejemplificar, los grupos del rock argentino que se manifestaron en democracia abrazaron la tensión, se abocaron a la profusión semántica de sus discursos e intentaron apartarse del culto singular y para pocos con el objeto de reubicar así libertades en pugna y abordar identidades desde instancias discursivas y comunicativas variadas (medios de comunicación, panfletos, discos y letras, por ejemplo).

En tiempos de recuperación democrática, los jóvenes construyeron así sus prácticas desde la autonomía y minimizaron la relación con el sistema político: habilitaron los instrumentos de la democracia representativa (como espacio de elección y como modo de separarse del autoritarismo) y re-significaron el espacio público con presencia callejera y ocupaciones de territorios que acompañaron el clima social y político de una sociedad que se encontraba efervescente a partir del proceso de transición democrática. Asimismo, conviene destacar que a partir del advenimiento democrático el rock argentino comenzó a perder su rol de sostén de la identidad joven (como había sucedido durante la dictadura) a causa de la reaparición de los partidos políticos, la organización 
de los movimientos de derechos humanos y/o sindicatos.

El colectivo juvenil que se vinculó con el rock buscaba formas de participación alternativas a los canales clásicos e instituía otro tipo de prácticas expresadas que ingresaban en la vida cotidiana y se alejaban relativamente de las vías institucionales conocidas de la política (Vommaro, 2013: 11). Se advirtieron así transformaciones a partir de las tensiones y las valoraciones de los márgenes. Se encontraron, además, significaciones que nutrieron un ideario rebelde y libertario que se profundizó en las décadas siguientes. La diversificación de los consumos culturales, en definitiva, generó tensiones con las estéticas permitidas e instituidas y presentaron claras derivaciones en el presente. 


\section{Capítulo III}

\section{Marco temporal (1982-1989)}

\subsection{Aproximaciones al escenario histórico}

El propósito de este capítulo es dar cuenta de las problemáticas y los acontecimientos que atravesaron el período 1982-1989: un marco contextual que articuló tensiones y complejidades vinculadas a un ocaso dictatorial y a la entrada a un estado democrático. En este sentido, la revisión de dicha temporalidad entiende que el marco contextual subrayó un momento seminal de legitimación y revalorización de la convivencia democrática en relación con una disposición de libertad y configuración social.

En virtud de lo expuesto y para contribuir con la trama expositiva, se optó por desarrollar en dos secciones el tratamiento del escenario histórico. Por un lado, se evidencia la contextualización política y económica de la Argentina durante el marco de transición democrática; y por otro, se aprecia la situación de la cultura rock vernácula en dicho escenario temporal. Esta división, se aclara nuevamente, no indica una comprensión separatista en relación a lo cultural y lo político, sino sirve a los fines de manifestar las instancias sociales que atravesaron el período propuesto.

Este marco detallado corresponde a un tránsito post-autoritario que implicó reconfiguraciones, reconversiones y renovaciones. El cotejo de este período permite reflexionar sobre tópicos recurrentes de las prácticas sociales, políticas y culturales de nuestro país que aún hoy se encuentra en tensión. El examen breve de esta coyuntura, en términos puntuales, expone ciertas limitaciones y también abarcamientos de la voluntad política de un gobierno en democracia y de un fenómeno cultural como el del rock argentino.

\subsubsection{Un escenario político-social de reconfiguración}

Hacia 1982, la situación de la dictadura militar se encontraba en crisis por conflictos sociales, económicos y políticos. En efecto, la continuidad del régimen militar se desmoronaba en un contexto que los relacionaba fuertemente con crímenes de lesa 
humanidad, asesinatos masivos, fusilamientos, planes sistemáticos de desapariciones, organización de campos de concentración y distintos actos de censura.

Indudablemente, la finalización de la trágica guerra de Malvinas trajo aparejado un complejo de consecuencias graves que obligaron a la dictadura a poner fecha para el retorno de la democracia y, consiguientemente, a levantar la veda política. La sociedad se mostraba impiadosa con los que condujeron al país hacia el desastre y repudiaba abiertamente a los oficiales y altos mandos responsables de la derrota en el atlántico sur $\mathrm{y}$, en cierta medida, de las actuaciones durante el proceso de terrorismo de estado (Suriano y Álvarez, 2013: 147).

La coyuntura de transición se inauguró a partir de un fuerte cataclismo que combinó fracasos en tres frentes decisivos como el económico, el político y el militar (Cavarozzi, 1997: 65). Así, los malestares sociales se vinculaban con los actos de corrupción, las ineptitudes en relación con el dominio de la economía (fortaleciendo a las grandes corporaciones y profundizando la deuda externa) y la difusión (oportuna y mediática, vale decir) de hechos aberrantes y concretos durante la dictadura o la divulgación de denuncias de las organizaciones de derechos humanos (Las Madres y Abuelas de Plaza de Mayo, por ejemplo).

Estas organizaciones de defensa no sólo colocaron la cuestión de los desaparecidos en el centro mismo del debate, poniendo a los militares a la defensiva, sino que impusieron a toda la práctica política una dimensión ética, un sentido del compromiso y una valoración de los acuerdos básicos de la sociedad.

A partir de ello, los partidos políticos contribuyeron en la aceleración de la retirada militar y forjaron el camino hacia la restitución democrática:

La democracia fue en primer lugar una ilusión: la tierra prometida (...) aparecía como la llave para superar desencuentros y frustraciones, no sólo creando una fórmula de convivencia política, sino también solucionando cada uno de los problemas concretos (Romero, 1999: 238).

El final de la guerra de Malvinas provocó entonces el quiebre definitivo de la relación entre la sociedad y los militares, quienes ante el desprestigio general y la agobiante situación económica del país llamaron a elecciones para octubre de 1983. En consecuencia, el Partido Justicialista (PJ) y la Unión Cívica Radical (UCR) presentaron sus propuestas de gobierno y postularon a sus propios candidatos presidenciales: el PJ 
designó a Ítalo Argentino Luder y la UCR eligió a Raúl Alfonsín como representante en las urnas.

No obstante, como era de esperarse, los ejes de campaña de Luder y Alfonsín eran disímiles. Mientras que el peronismo centraba su discurso en la pacificación y en la salida de la crisis económica, Alfonsín "se mostraba como un político con capacidad de comunicación, buena retórica y naturalidad ante las cámaras de televisión" que buscaba convencer a los sectores menos confrontadores de la sociedad y denunciar a aquellos que querían proseguir con el sistema de impunidad inaugurado en 1976 (Angeli, 2005: 117). En este sentido, su acusación más fuerte se produjo cuando anunció un "pacto militar-sindical", en el que destacaba los vínculos y las estrategias del peronismo y los jerarcas militares:

\footnotetext{
Días antes de los comicios, en una conferencia de prensa, Alfonsín denunció públicamente la existencia de un supuesto pacto militar-sindical contra la democracia, que comprometería a Lorenzo Miguel, líder de los metalúrgicos, y a oficiales superiores del ejército. El candidato radical intentó demostrar la complicidad entre el Ejército y los dirigentes sindicales, y acusó a estos últimos de ser parte de la vieja Argentina que él quería cambiar (Angeli, 2005: 117).
}

Las elecciones del 30 de octubre se llevaron a cabo de un modo satisfactorio y la población concurrió masivamente a emitir su sufragio. Seguidamente, la fórmula Alfonsín-Martínez ganó con el 52\% de los votos contra el 40\% de los peronistas LuderBittel. El candidato radical triunfó con el apoyo de algunos sectores de las clases trabajadoras, la clase media y los grandes terratenientes e industriales. Asimismo, la UCR ganó en las zonas más carenciadas, quebrando una racha histórica que siempre benefició al PJ.

\subsubsection{Apertura democrática}

El 10 de diciembre de 1983, diez años después de la última elección presidencial (que dio por ganador a Juan Domingo Perón), Alfonsín asumió como Jefe de Estado e inició un período democrático ansiosamente esperado por gran parte de la población. Como primer medida de gobierno, el ejecutivo derogó la ley de "auto-amnistía" por considerarla anticonstitucional y la declaró nula, sentenciando lo siguiente: "Una vez 
más se demuestra que al régimen militar nada le importa la opinión del pueblo, porque lo único que guía es entonces desesperadamente una salida a las responsabilidades por los actos que él mismo produjo en el pasado" (Romero, 1999: 238).

Asimismo, Alfonsín firmó el decreto 158 y ordenó la iniciación de juicios sumarios a los dictadores y represores de la última dictadura cívico militar: los generales Videla, Viola y Galtieri, los brigadieres Agosti, Graffigna y Lami Dozo, y los almirantes Massera, Lambruschini y Jorge Anaya (todos ellos jerarcas de las primeras tres juntas militares del régimen saliente). No obstante ello, a través del decreto 157/83, el presidente radical dispuso también la persecución de los jefes de las organizaciones armadas para juzgarlos por acciones cometidas a partir del 25 de mayo de 1973, día en que Héctor J. Cámpora iniciaba su corto mandato.

El cierre de la incidencia brutal del terrorismo de Estado propulsó una revalorización generalizada acerca del concepto de democracia y sus valores éticos, morales y ecuánimes. Los años del 80 o, más precisamente, los que nuclean el período 1983-1989 no significaron un borrón y cuenta nueva (inmediato y efectivo) en torno al terror dictatorial, sino que sobrellevaron transversalidades y cimentaron caminos de diálogo/disputa/tensión entre distintos sectores de la sociedad. La formación de una cultura política democrática se expresó a partir de la vida cotidiana, las relaciones familiares, y las formas de sociabilidad de los argentinos.

Asimismo, los partícipes de la cultura (en tanto intelectuales y artistas) debieron forjar un campo de actuación teniendo como referencia la renovada voluntad política expuesta por parte de la sociedad y la consolidación de la cultura política en términos de democracia y estado de derechos (Landi, 1984: 64).

El principal propósito que se buscaba en esta instancia de reconstrucción democrática se vinculaba con la reinstauración de principios básicos de constitucionalidad y las nuevas conceptualizaciones en torno al concepto de democracia como valor universal e imprescindible para la configuración social de la política.

La primera semana de gestión alfonsinista estuvo signada por un hecho fundamental, la creación de la Comisión Nacional de Desaparición de personas (CONADEP), que tenía como fin principal recabar información acerca de los casos de violaciones de derechos humanos cometidas durante la dictadura y ponerlo a disposición de la justicia civil. El trabajo (que reconocía la desaparición de cerca de 9 mil personas y un total de 1.086 casos denunciados a la justicia) dio cuenta del papel represivo que tuvo la dictadura entre 1976 y 1983 y expuso la existencia de centros clandestinos de concentración a lo 
largo de todo el país, entre los que se destacan la tristemente célebre Escuela de mecánica de la armada (ESMA), la Perla (Córdoba) y la escuelita de Faimallá (Tucumán), por citar solo tres ejemplos:

La democracia refundada en 1983 comenzó con el impulso de imponer el castigo que merecían los violentos de los años de plomo. Las tareas de la CONADEP y el impecable Juicio a las Juntas (ver más adelante) fueron motivos de admiración mundial. En nuestro país las revelaciones de los métodos aplicados por el terrorismo de estado se acumularon en la prensa hasta desbordarse en un show del horror que estremeció la sensibilidad de todos (Pasquín Durán, 1993: 96).

El anhelo de vivir bajo un proceso democrático duradero (y por ello, inédito en nuestro país) recayó en todos los estamentos de la sociedad, pero principalmente en la figura de Raúl Alfonsín, quien indicaba que la democracia serviría para comer, educar y curar. De este modo, democracia y política se unieron bajo un principio insoslayable que las hermanó y las involucró en una misma percepción: respirar aire nuevo y rechazar el horror dictatorial. A pesar de ello, la relación del gobierno democrático con los salientes militares significó un escollo fundamental para el desarrollo de la gestión radical.

La llamada "fundación alfonsinista" estuvo vertebrada sobre la ruptura con el espectro de dos pasados: en primer lugar, el inmediato contexto de autoritarismo, violencia y muerte de la dictadura; en segunda instancia, el "faccionalismo" hegemónico de la presencia militar y la imposibilidad de desarrollar una conciencia democrática (Aboy Carles, 2013: 78).

\subsubsection{Aproximaciones cotidianas}

El mayor interés del gobierno radical se centró en el problema político, y por ello, trató de eliminar los residuos del autoritarismo y apoyar nuevas maneras de participación ciudadana. En este sentido, se reforzaron las políticas culturales y educativas con el propósito de renovar sus contenidos El ejecutivo propuso una modernización con pluralidad y participación social, tratando de derribar los mecanismos represivos del sistema educativo propios de la dictadura. De esta manera, se generaron subsidios para encauzar los conflictos educativos y mantener la libertad y el pluralismo emergente. 
Entre 1984 y 1985, los medios de comunicación comenzaron a hacerse eco de la denuncia y el compromiso social ${ }^{9}$. La consecuencia más importante fue la inclusión de las problemáticas sociales en las agendas periodísticas, dado que comenzaron a proliferar informes sobre víctimas del terrorismo de estado, homosexuales, drogadicción, desocupación y pobreza, entre otros aspectos. Igualmente, el denominado "destape" incluyó al erotismo en las vidrieras y los kioscos de revistas, en tanto que las expresiones académicas, cinematográficas, teatrales y musicales vivenciaron una etapa de esplendor creativo y artístico.

El sobrevenir la democracia se comparó con lo sucedido tras la finalización de la dictadura de Francisco Franco en España a partir de 1976. Se estrenaron películas y se editaron libros que habían estado prohibidos, se publicaron revistas con desnudos (Humor, El Porteño, Periodistas, más tarde Cerdos y Peces del periodista y escritor Enrique Symns) y artículos sobre aborto, homosexualidad, drogas, pedofilia, y un sin fin de temas más que hasta ese entonces nadie había tocado. El tema de los derechos humanos (DD. HH.), que contenía la temática de los desparecidos, la apropiación de chicos, la tortura y la deuda externa se impuso como discurso hegemónico en los medios nacionales (Secul Giusti y Rodríguez Lemos, 2011).

\subsubsection{Avance en retroceso}

En materia de DD.HH., el año 1985 fue promisorio debido a la realización del Juicio a las tres primeras juntas militares. Tal proceso judicial logró que la gestión de Alfonsín se convirtiera en un ejemplo de las democracias recuperadas de toda Latinoamérica, dado que la Argentina se convirtió en el único país de la región en condenar a los encargados máximos de un régimen dictatorial. A lo largo del juicio, brindaron su testimonio 700 personas y se procesaron a 450 oficiales.

Sin embargo, las condenas más resonantes tuvieron como protagonistas a los dictadores Jorge Videla (reclusión perpetua), Emilio Massera (prisión perpetua), Orlando Agosti (cuatro años y seis meses de prisión), Roberto Viola y Armando Lambruschini (diecisiete y dieciocho años de prisión). La expresión remarcada durante el Juicio que se resumió mediante el enunciado Nunca Más, ofreció un relato fundamental de esa

\footnotetext{
${ }^{9}$ Por ejemplo, las ficciones de la televisión trataban las problemáticas producidas en la dictadura, desde las desapariciones hasta el exilio.
} 
experiencia que destacaba el lugar de las víctimas. El juicio a las Juntas constituyó la marca de un cambio histórico y el símbolo mayor de la transición a la democracia: “instaló la escena de la ley como una reconstrucción que vino a desmantelar, más o menos duraderamente, el escenario de la guerra" (Vezzetti, 2002: 109).

Por tanto, el Juicio actualizó una versión distintiva de la llamada teoría de "los dos demonios". Se construyeron así las dos formas de la intolerancia por antonomasia que continúan hasta la actualidad, pese a los trabajos del estado durante 2003 y 2015 y la lucha de las organizaciones de DD.HH., hasta la actualidad: por un lado, el llamado "terrorismo" de ultra-izquierda y por otro, la violencia estatal de la ultra-derecha. En el terreno jurídico, la teoría de "los dos demonios" se reconfiguró a partir del proceso simultáneo de las Fuerzas Armadas y de los jefes sobrevivientes de Montoneros y ERP: "En este plano el sentido de los "dos demonios" se limitaba al acto fundamental que, en todo caso, venía a establecer, en general y para el futuro, que no había prácticas políticas que pudieran situarse por encima d la ley" (Vezzetti, 2002: 122).

En lo que refiere a la expresión Nunca Más, instalada por las políticas y las decisiones teóricas del alfonsinismo/radicalismo durante la década del 80 , vale decir que constituyó una potente imagen interpretativa en torno a los enfrentamientos entre organizaciones armadas y fuerzas institucionales y para-institucionales de un modo maniqueo e injustamente equiparado. Esta conceptualización surgida en el gobierno de Alfonsín postulaba, de hecho, una victimización de la sociedad que la colocaba en un lugar de “espectadora y víctima de lo ocurrido, ya que se sostenía que había resultado engañada y perjudicada por una guerra entre dos grupos armados: los militares de un lado y los guerrilleros del otro" (De Amezola, 2014: 18).

Al respecto, la investigadora Florencia Levín señala que la principal representación sobre el pasado reciente, que podríamos llamarse "Memoria del Nunca Más", ofreció una visión del pasado cercano acorde con las necesidades y expectativas del momento: "Lo que esas representaciones ocluían era, precisamente, hasta qué punto la sociedad pretendidamente inocente y víctima había contribuido a la creación de un clima favorable al golpe y hasta qué punto esa misma sociedad había avalado y consensuado la llegada de Videla al gobierno" (Levín, 2014: 7).

No obstante, la solución con los altos mandos castrenses distaba de estar resuelta. Luego del proceso que enjuició a las cúpulas de mando en los años de plomo precedentes, los militares de menor rango temían por su futuro, debido a la enorme cantidad de denuncias de violaciones a los derechos humanos que recaían sobre ellos. Durante los 
primeros meses de 1986, con el juicio a las Juntas como referencia inobjetable, los jueces civiles citaron a los oficiales de menor rango y la situación se volvió insostenible. Por ello, a fines de ese mismo año, el gobierno radical tomó una decisión polémica: dictó la ley de Punto Final y puso una fecha límite para las denuncias sobre delitos cometidos por las fuerzas de seguridad durante la dictadura militar (el tope de tiempo para las denuncias se estipuló entre los meses de enero y febrero de 1987).

Esta decisión política basada en un polémico cálculo de fuerzas demostró ser endeble y materializado por las denominadas leyes de Punto Final y de Obediencia Debida (Romero, 1999: 250). La primera, dictada hacia finales de 1985 y aprobada por el congreso entre el 22 y 23 de diciembre de 1986, dinamitó la esperanza que buena parte de la sociedad tenía en el gobierno de Alfonsín. De este modo, no pudieron atenuar los ánimos de los militares: las denuncias se multiplicaron y el gobierno no pudo revertir su política de enjuiciamiento a los responsables del terrorismo de estado.

Sumado a esto, a comienzos de 1987 los militares reaparecieron en la escena política de un modo dramático, en lo que sería el primero de una serie de planteos de las Fuerzas Armadas. La crisis militar de la llamada "Semana Santa" provocó momentos de tensión pujante: exhibió una institucionalidad debilitada y perjudicó la autoridad de Alfonsín: "Los planteos posteriores a la semana santa de 1987 acentuaron el desgaste del presidente, que se vio obligado a recurrir a soluciones ad hoc como la ley de Obediencia Debida; estas aparecieron ante la población como concesiones que, al mismo tiempo, no satisfacían los reclamos militares" (Cavarozzi, 1997: 74).

La concepción de las leyes de Obediencia Debida y Punto Final tensionaba con la idea de dar una solución rápida a las violaciones de los derechos humanos durante la dictadura. Los ciudadanos comprobaron que la realidad no era tan plástica como suponían y que la fuerza de la civilidad, importante para algunas cosas, "servía de poco frente a poderes opacos, pero resistentes. Esto se constató en Semana Santa de 1987: poco podían contra una corporación militar decidida a defender a los suyos" (Romero, 2004: 274):

El repudio a la violencia movilizó a los ciudadanos, que se lanzaron a las calles cuando grupos remanentes de violentos uniformados se pintaron las caras con betún y tomaron cuarteles: Campo de Mayo (Semana Santa, 1987) y Monte Caseros (1988) bajo la jefatura de Aldo Rico; Villa Martelli (1988) con Mohamed Ali Seineldín a la cabeza (...) Eran nacionalistas autoritarios que se reivindicaban 
como héroes de Malvinas, repudiaban por blandos a sus estados mayores, querían terminar con los tribunales que juzgaban los crímenes cometidos en el proceso, en nombre de la Obediencia Debida, y miraban con mucha simpatía a la candidatura de Carlos Menem (Pasquín Durán, 1993: 97).

Las experiencias negativas de la UCR fueron aprovechadas por un partido peronista revitalizado por la figura del hasta entonces gobernador reelecto de La Rioja, Carlos Menem. La derrota electoral de medio término afectó fuertemente la imagen pública y los aspectos de poder del gobierno de Alfonsín.

\subsubsection{El ocaso primaveral}

La presión de los grandes grupos económicos logró que el gobierno radical retrocediera e incentivara, principalmente, a las exportaciones y las inversiones extranjeras. Como consecuencia de ello, Grinspun dejó el cargo en febrero de 1985 y fue reemplazado por Juan Vital Sourrouille. El giro económico se hizo público cuando el propio Alfonsín (el 27 de abril de ese mismo año) pronunció que se debía implantar una "economía de guerra" y dejó deslizar que se efectuaría una suba de impuestos y una reducción del gasto público como principales iniciativas, lo cual significó un duro golpe a su popularidad entre los sectores más progresistas.

Para detener las deficiencias económicas, el gobierno radical delineó lo que sería el lanzamiento de un nuevo programa económico: el Plan Austral. A pesar de la desconfianza y la resistencia de los líderes sindicales, el Plan Austral tuvo un inicio promisorio, puesto que se consiguió bajar la inflación y con ello, quitarle la bandera de lucha que enarbolaba el sindicalismo. Este espaldarazo económico coyuntural le otorgó credibilidad al gobierno radical, que ganó las elecciones legislativas en diecinueve provincias y en distritos clave como Capital Federal. Sin embargo, poco tiempo después, el déficit fiscal logró que la economía se precipite y entre en cesación de pagos a las entidades internacionales y que no logre mejorar los niveles de consumo.

La economía aportó una dimensión más para el deterioro y, por lo tanto, el deterioro financiero del país se agravó en los años subsiguientes del mandato radical. Así, la inflación se incrementó y el dólar se volvió indomable para el gobierno, obturando así las expectativas sobre el Plan Austral. Seguidamente, el control de la inflación se hizo cada vez más problemático y comenzaron las demarcaciones preventivas de precios y 
aumentaron las presiones de los grandes empresarios para resistir reformas tributarias (Angeli, 2004: 130).

Por tanto, el último esfuerzo antiinflacionario que empleó el gobierno de Alfonsín se vinculó con la creación del Plan Primavera, anunciado en agosto de 1988. No obstante ello, el nuevo pacto económico se mostró endeble a los pocos meses y una serie de acontecimientos políticos y sociales malogrados complicó potentemente el destino radical: se sucedieron estallidos sociales en capitales de distintas provincias por salarios impagos y complicaciones inflacionarias, que aumentaron la tensión entre los gobernadores justicialistas y las Fuerzas Armadas.

\subsubsection{El final adelantado}

El último tramo del gobierno de Alfonsín destacó un vacío de contención y una situación impopular hacia las decisiones tomadas por la gestión radical en los últimos meses de la presidencia. En este sentido, se resaltan tres cuestiones elementales, entre tantas: la pérdida del rumbo político, la entrega del proyecto a manos conservadoras y las desestabilizaciones de los grandes grupos económicos. Asimismo, la búsqueda de la reconciliación por medio de una vía intermedia resultó ser la meta que contaminó el capital político del gobierno y le impidió imponerse a las resistencias militares (Novaro, 2013: 48).

Sumado a esto, el año 1989 comenzó del peor modo para el gobierno radical tras la toma del regimiento de La Tablada que generó una masacre y la reapertura de conflictos entre civiles, militantes políticos y fuerzas armadas:

El gobierno ya no encontraría forma de controlar la situación, porque las malas noticias continuaron como asimismo sus errores. El 23 de enero un grupo remanente del ERP que actuaba bajo la cobertura de una organización juvenil y universitaria con estrechos lazos con organismos de Derechos Humanos denominada Movimiento Todos por la Patria (MTP) asaltó el regimiento de tanques de la Tablada. La policía pretendió intervenir para detener al grupo atacante, pero grupos comando del ejército se lo impidieron y lanzaron una feroz operación. Hubo 39 muertos, al menos 3 desaparecidos y varias decenas de heridos (Novaro, 2010: 221). 
Asimismo, los meses previos a las elecciones presidenciales de 1989 y, por consiguiente, a la renuncia de Alfonsín fueron caóticos. Una vez electo el presidente Carlos Menem, estalló la hiperinflación que desesperó a gran parte de la sociedad y afectó las economías de distintas regiones: "La desesperación de los más pobres se tradujo en estallido social y saqueos a los supermercados. Esas imágenes, que se repitieron en cadena en todas las ciudades argentinas, recorrieron el mundo" (Seoane, 2004: 174). Esta crisis económica fue comprendida, a lo largo de los años, como un golpe estructural de lo grupos económicos, puesto que no se vinculaba una situación crítica de distribución del ingreso, sino una disputa entre grupos económicos internos y acreedores externos.

En lo político, la crisis afectó directamente la imagen del gobierno de Alfonsín y lo obligó a renunciar anticipadamente, desgastado por un fracaso económico imperante y por haber negociado la impunidad de los crímenes de la dictadura, en los años previos. Por esto mismo, el 8 de julio se concretó el traspaso del mando al ex gobernador Menem. A partir de ello, se cumplió el deseo que implicaba una entrega del poder a otro mandatario electo, una distinción que, en líneas generales, no sucedía desde 1928, y entre distintos partidos, desde 1916. No obstante, esto último se lograba en condiciones políticas, económicas y sociales que estaban muy lejos de ser las más deseables (Novaro, 2010: 223).

\subsection{La escena del rock argentino (1982-1989)}

Antes de ingresar al contexto que convoca al rock argentino y lo vincula con el período seleccionado, vale aclarar que hacia esa época, la cultura rock argentina ya llevaba quince años de historia. Es decir que se encontraba atravesada por las tensiones y las nociones propias del devenir político y cultural del país. Específicamente, el rock argentino nació en un contexto de democracia restringida y emprendió su desarrollo contracultural a la sombra de la dictadura militar de Onganía (1966-1970).

La lógica cultural del rock argentino comenzó hacia mediados de la década del 60 y se desenvolvió a partir de tres hechos fundamentales: el primero de ellos fue la grabación del disco debut de Los Gatos Salvajes (1965); el segundo se debió al lanzamiento del disco simple "No Finjas más/Rebelde" de los Beatniks (1966); y el último se vinculó 
con la edición del sencillo “Ayer nomás/La Balsa” de Los Gatos $(1967)^{10}$. Estos eventos significaron los puntos de partida elementales para producir un rock cantado en castellano que trascendió el mero deseo para convertirse en una identidad reconocida a lo largo de toda Latinoamérica.

En efecto, entre 1966 y 1975, las líricas de los artistas del movimiento (Litto Nebbia, Tanguito, Javier Martínez, Luis Alberto Spinetta o Charly García, entre otros) se consagraron en consonancia con un "nivel de agitación y participación política de los sectores juveniles sin precedentes en la historia" (Alabarces, 1993: 92). Asimismo, como apunta Sergio Pujol, la zona de rock se asentó sobre una serie larga de impugnaciones, por ejemplo:

Contra la escuela como extensión de la educación patriótica (“Ayer nomás”); contra el mundo dado e impermeable al cambio ("La Balsa"); contra la moral sexual burguesa ("Muchacha ojos de papel" y más tarde "Catalina Bahía"); contra la metodología del accionar policial ("Blues de la amenaza nocturna", "Apremios ilegales" y "Botas Locas”), y así sucesivamente (Pujol, 2002: 168).

El rock argentino creó un prolífico período contracultural en el que se pulieron líricas y sonidos, y desplegó una trama social, formada por audiciones de radio, prácticas aledañas o emparentadas con los recitales (artesanías, vestimenta, pelo largo) y algunas revistas de orientación rockera (Pujol, 2002: 171). A la par, en esta etapa se produjeron obras que quedaron, históricamente, en la memoria colectiva del movimiento rock y la cultura de nuestro país, como por ejemplo, Los Gatos (1967), Almendra (1969), Manal (1970), Pappo's Blues Vol I (1971), Desatormentándonos (1972) de Pescado Rabioso, Vida (1972) de Sui Generis, Artaud (1973) de Luis Alberto Spinetta/Pescado Rabioso, Muerte en la Catedral (1973) de Litto Nebbia, Brumas (1974) de Aquelarre y Durazno Sangrando (1975) de Invisible, entre otras.

\footnotetext{
${ }^{10}$ Este sencillo se editó el 3 de julio de 1967 y significó un éxito extraordinario. La Balsa vendió más de 250.000 copias y significó un éxito extraordinario, sobre todo si se la compara con las ventas de Rebelde de los Beatniks, antecesor directo que no superó los 600 discos vendidos. Asimismo, Pablo Alabarces señala que el rock cantado en castellano tiene dos tipos de fundaciones (1993: 61). La primera, en 1962, con el Club del Clan (programa televisivo juvenil de la década) y la segunda, tres años después, tras la grabación del disco Los Gatos Salvajes (representantes de una veta más contracultural).
} 


\subsubsection{Rock y dictadura}

La presencia de la dictadura cívico militar instaurada el 24 de marzo de 1976 promovió una política de censura en torno a lo cultural y educativo y en sintonía con su política represiva del terrorismo de Estado. Así, el régimen militar creó un grupo especial encargado de controlar todo tipo de producción científica, cultural, política o artística y, sobre todo, de alcanzar el disciplinamiento social y cultural de la sociedad.

El rock argentino, como se indicó, no estuvo ajeno a la situación porque fue perseguido, censurado y criticado por la sociedad conservadora. No obstante, el debate conceptual que se abrió a partir del advenimiento democrático en 1983 se relacionó con la propia actividad del rock argentino en tiempos dictatoriales. Tras el golpe de Estado de 1976, la cultura rock argentina se convirtió en uno de los pocos espacios de disidencia contra el régimen militar.

Al respecto, las líricas no planteaban una crítica feroz del aparato represivo de la dictadura, sino buscaban configurar un espacio de identificación, más proclive a la integración y a la disidencia en términos menos directos. No obstante, fue también, durante estos años de terror y muerte, que los exponentes comenzaron a autodefinirse como partícipes del "rock nacional”, alejándose, de esta manera, de la llamada "música progresiva":

En este contexto el rock nacional se constituyó en el imaginario de muchos jóvenes en uno de los pocos movimientos que se opuso a la dictadura miliar, al sostener simbólicamente una identidad que fue duramente reprimida por la dictadura: la identidad joven. En este gradual proceso de masificación el rock fue progresivamente siendo identificado como la música que representaba al conjunto de los jóvenes urbanos (Semán y Vila: 1999: 237).

En este sentido, vale decir que la dictadura no había postulado como enemigo directo a la cultura rock argentina. Sin embargo, simbolizaba un estorbo y una molestia para el desarrollo de los llamados "valores occidentales". Por ello mismo, los actores implicados en esta cultura recibieron amenazas y persecuciones que, si bien generaban terror y complejidades, no se relacionaban con los acontecimientos de secuestro, tortura, muerte y desaparición que atormentaban a los jóvenes que tenían implicancias político- 
revolucionarias o que simpatizaban con acciones rebeldes e insurreccionales, entre otros.

\subsubsection{Malvinas y después}

El fin de la dictadura produjo una bisagra importante en el movimiento del rock argentino. Si bien su difusión había dejado de ser estigmatizada desde el ingreso del dictador Viola al poder en 1981, el nuevo proceso democrático produjo una serie de transformaciones en toda la cultura argentina. Aparecieron bandas que, entre otros objetivos, proponían una diversidad de temáticas en las composiciones y buscaban la integración a un circuito comercial más amplio. Así, la recuperación de las instituciones democráticas permitió una mayor expresión y un rechazo general de las formas autoritarias.

Esos años de cambios políticos, sociales y económicos posibilitaron una emergencia creativa que se vivenció en la cultura del país y emergió de los centros de las zonas urbanas del país, tomando como puntos referenciales a las ciudades de Buenos Aires, el Gran Buenos Aires, La Plata, Rosario y Córdoba o Mendoza, en menor medida. Ante esto, el teatro, las publicaciones alternativas, el cine y la música, a través del rock, tuvo un impacto expresivo notable luego de años de censura.

Por tanto, luego de la guerra de Malvinas, el rock argentino jugó un rol central en la reinstalación de la vida democrática, dado que, a partir de la prohibición de música en inglés durante el conflicto, construyó un escenario que lo llevó a la masividad, al éxito y a los conflictos internos ${ }^{11}$. En este aspecto, se experimentó un estallido inédito en su

\footnotetext{
${ }^{11}$ Como señala Carlos Polimeni, es imposible repasar la época atormentada y difícil de Malvinas sin mencionar "la jornada en que los grandes del momento 'pisaron el palito' de la dictadura al participar en un 'Festival de la Solidaridad', concebido desde el poder para que figuras del predicamento sobre los jóvenes aparecieran apoyando a los pobres soldados de la patria” (Polimeni, 2006: 184). El evento, organizado íntegramente por las Fuerzas Armadas y los empresarios Daniel Grinbank, Alberto Ohanián y Pity Yñurrigarro, se llevó a cabo el 16 de mayo de 1982 en la cancha de rugby del estadio Obras sanitarias y convocó a más de sesenta mil espectadores. En contraste con la participación de Luís Alberto Spinetta, Charly García, León Greco, Raúl Porchetto, Miguel Cantilo-Jorge Durietz (Pedro y Pablo), entre otros, dos bandas sobresalieron por negar su asistencia: Los Violadores y Virus. No obstante, los músicos que participaron del festival intentaron dejar en claro que no actuaron para respaldar la guerra, sino que lo hicieron pensando en los soldados que resistían y peleaban en Malvinas.
} 
historia que contrastó con la persecución, la censura y la marginación padecidas en años anteriores.

El inicio del conflicto con Gran Bretaña por el tema Malvinas significó la posibilidad de la difusión masiva del rock argentino en los medios de comunicación escrita, radial y audiovisual, y produjo también un "aceleramiento de la ya acentuada masividad del fenómeno" (Vila, 1985: 105). A raíz de estas condiciones particulares, el rock argentino incrementó la producción y venta de sus discos, y se posicionó como un producto altamente redituable: "De los treinta y siete LP de 1981 (igualmente significativos frente al piso de dieciséis en 1979) se pasó a sesenta y tres (durante) 1982” (Alabarces, 1993: $85)$.

De acuerdo con este contexto, la oferta del movimiento no se hizo esperar y los grupos e intérpretes empezaron a surgir velozmente bajo el rótulo de rock nacional. Así, el rock argentino vivió una "institucionalización” extraña que se llevó cabo a través de ámbitos privados (sellos, sponsors, medios de comunicación no estatales, etc.), al tiempo que se aprovechó de su pleno auge y comenzó a criticar a una dictadura que ingresaba a una etapa final y decadente.

Por consiguiente, los recitales se convirtieron en espacios privilegiados para el encuentro y la comunicación de los jóvenes seguidores de rock. En términos de Vila, eran ámbitos de construcción de la libertad y de "utopía realizada" que desde el conjunto expresaban y sentían lo mismo, conformando así "un movimiento de opinión, de real envergadura" que anticipaba la libertad por venir" (1985: 108).

\subsubsection{Underground y reconfiguraciones}

En paralelo a esta situación controvertida, el rock vivenció también un retorno al underground (por fuera de los carriles que la industria delimitó entre los años 19671981) y forjó un territorio suburbano y periférico que acuñó a una gran parte del rock masivo de la democracia. De esta forma, la actividad musical se ofreció como un gran semillero o "criadero de ídolos" a futuro que concluía con la "homogeneización imaginaria" de estilos y búsquedas estéticas postuladas durante la dictadura militar (Alabarces, 1993: 86).

A partir del fenómeno de los pubs y de los recintos nocturnos, se robusteció una escena alternativa de cultura rock que proponía una intención inocentemente "no comercial" y permitía el desfile de bandas distintivas como Sumo, Los Twist, Los Redonditos de 
Ricota o las Bay Biscuits, entre otros. Al respecto, Vila señala que el cántico "Paredón, paredón..." convivía en pie de igualdad con el recordado "Se va a acabar la dictadura militar..." y se hacía presente tanto en los espectáculos brindados por los referentes de rock más ligado a la canción y a la balada (Juan Carlos Baglietto, Alejandro Lerner, Charly García, Miguel Cantilo) y en los que simpatizaban con los contenidos antimilitarista desde sus líricas y sus posturas escénicas (Riff, V8, La Torre, Los Violadores) (Vila: 1985: 106-109).

A partir de la segunda mitad de 1982, el aspecto musical y organizacional aumentó en relación a la cantidad de conjuntos identificados con los sonidos new wave y heavy metal $^{12}$. Durante este proceso de apertura y reconfiguración cobraron relevancia las nuevas propuestas artísticas de Juan Carlos Baglietto, Celeste Carballo, La Torre, Zas, Horacio Fontova, Suéter y los mencionados Violadores y Alejandro Lerner.

En tanto, también recogieron relevancia las re-apariciones de Norberto "Pappo" Napolitano (en grupo, bajo el nombre Riff), Charly García (en plan solista) y Los Abuelos de la Nada (en su segunda, distintitiva y rejuvenecida versión). Por otra parte, músicos de la talla de Moris, Litto Nebbia, Gustavo Santaolalla o Emilio Del Guercio regresaron al país luego de años de exilio (forzado o auto-impuesto). Asimismo, la vuelta de Mercedes Sosa significó un cimbronazo para el rock y configuró una reconciliación con el folclore. Mientras que la artista compartía escenario con León Gieco, Charly García y Alejandro Lerner, su público, tradicionalmente folklórico, inauguraba una categoría nueva para el rock y la música en general: los psicobolches ${ }^{13}$. De esta forma, se produjo una breve precipitación de la contemplativa militante y contestataria de los 70 en la estética de un denominado "target progre".

No obstante ello, el rock argentino también libró una suerte de batalla casera entre los artistas que habían batallado culturalmente en los años previos y los modernos que se

${ }^{12}$ El heavy metal (metal pesado o metálico) es un género musical que nació a mediados del 60 en Gran Bretaña y que es característico por el empleo de guitarras distorsionadas, de voces agudas y líricas que pueden incluir una estética diversas: desde la acepción satánica hasta la distinción urbana, trabajadora, anti-patronal y psicodélica.

${ }^{13}$ El rótulo psico-bolche fue utilizado ampliamente para calificar a los idealistas progresistas o de izquierda que, en tiempos de democracia, se incluyeron desde una perspectiva integradora, socialista y psicoanalizada, dejando de lado aspectos favorables hacia la lucha armada y la guerra de guerrillas. En este sentido, cabe recalcar que el mote psico-bolche también incorporó cuestiones despectivas que relativizaban el contenido práctico-político de aquellos que eran incluidos en el universo del psicobolchismo. 
relacionaban con las nuevas instancias de producción: "Los viejos rockeros husmeaban el aire algo desconcertados; algunos creían ver un tardío aunque merecido reconocimiento para esta música; otros más recelosamente desconfiaban de semejante consagración y promovían un regreso a los espacios marginales" (Berti, 1994, 41) ${ }^{14}$.

\begin{abstract}
Muchos de los nuevos músicos despegaban de la vertiente rockera tradicional para rumbear hacia lo que se llamaría onda moderna ${ }^{15}$. Algunos de ellos respondían a en las entrevistas que su meta era hacer música "divertida". Finalmente, la confluencia de estilos y géneros se volvía tan total, que no era posible manejar con etiquetas simplistas. Indudablemente, casi dos décadas después de aquellas ya antiguas cadencias originales, otros crisoles habían entrado a funcionar (Cantarock, 1985: 42).
\end{abstract}

El rock terminó el año 1982 con dos multitudinarios eventos: por un lado, el retorno del BA Rock y por otro la presentación del primer disco de Charly García, Yendo de la cama al living. El año 1983, en suma, le abrió el juego a las campañas políticas y masificó las perspectivas del rock. Los artistas tenían cada vez más seguidores y, de hecho, muchos músicos pensaban que el movimiento se había convertido en un vehículo artístico fundamental de expresiones y sensaciones de la vida social y ciudadana. Al respecto, León Gieco declaraba: "Yo creo que (el rock) llegó al máximo de popularidad dentro del país (...) la gente va a tener más canales de expresión (...) Entonces van a ir a los recitales de rock o de quien sea, si consideran que es una música verdadera y auténtica" (Vila, 1985: 110).

\title{
3.2.4. El rock argentino, en contexto primaveral
}

La nueva situación del rock argentino durante la transición democrática y el efectivo estado de derecho, abrió un debate estilístico-ideológico entre modernos ${ }^{16}$, pop

\footnotetext{
${ }^{14}$ Conviene recordar las críticas que propició la banda Virus en su tema "Ay, iqué mambo!”: “Ay, ¡qué mambo! Hay todo un cambio. Ahora el rock vendió el stock. Nuestra canción salió al balcón ¿Hasta cuándo será este encanto?”; y asimismo, vale retomar las críticas realizadas por Patricio Rey y sus Redonditos de Ricota en la canción inédita "Pura suerte": "Esto ya, esto ya no es rock, mi amor. Es pura suerte".

${ }^{15}$ Utilización de la tipografía en negrita en el original.

${ }^{16}$ Término vinculado a la estética new wave.
} 
enfrentados a seguidores de heavy metal ${ }^{17}$, punks $^{18}$ y rockeros ${ }^{19}$. Así primero los espacios fueron ocupados por bandas pop que exponían estéticas divertidas (Los Abuelos de la Nada, Los Twist, Las Viudas e Hijas de Rock and Roll, producidos por Charly García) y por los "modernos” que reivindican la dimensión corporal y el baile como algo tradicionalmente dejado de lado por la corriente principal del rock nacional (Virus, Soda Stereo, Zas, etc.) (Semán y Vila, 1999: 238).

La asunción de Raúl Alfonsín provocó motivaciones de esperanza y prosperidad depositadas en la democracia. A pocos días de asumir, el gobierno radical terminó con las listas negras, las canciones prohibidas y las persecuciones de artistas. Un ejemplo claro fue la resolución número 29 del Comité Federal de Radiodifusión (COMFER), expedida el 9 de enero de 1984, que consideraba la libre transmisión y expresión de "las canciones musicales concebidas con respeto y mérito artístico" (Guerrero, 1994).

De hecho, el año 1984 permitió desarrollar el verdadero fenómeno del rock argentino de la década, dado que los nuevos exponentes del movimiento pasaron del circuito del pub y bares a las discotecas grandes, teatros y reductos más amplios ${ }^{20}$. Esto significó un pronunciado cambio generacional, puesto que los artistas nuevos demostraron actitudes mucho más divertidas y bailables que en las sufridas etapas anteriores.

La nueva camada pretendía publicar sus trabajos en un mercado que se presentaba en expansión, y aunque no hubiera lugares para todos, el objetivo consistía en buscar el lugar propio y explotarlo al máximo. Mientras tanto, Patricio Rey y sus Redonditos de Ricota o Sumo se hacían fuertes en el circuito underground, cultivando una estética que se enfrentaba a la expuesta por las bandas que lograban ingresar en el mercado discográfico.

El sociólogo Vila destaca que la propuesta divertida fue la más ensayada en el primer año de democracia. Sin embargo, esto no implicaba que los músicos no tuvieran plena

\footnotetext{
${ }^{17}$ Riff y V8 en un principio. Hermética y Logos, hacia finales de la década 80.

${ }^{18}$ Las bandas más reconocidas de la época eran Los Violadores y Attaque77 (en menor medida).

${ }^{19}$ Estos grupos, generalmente vinculados con la clase media, generaban contiendas con el establishment del mercado; las discográficas y se refugiaban en instancias underground. Sus mayores exponentes son Patricio Rey y Sus Redonditos de Ricota y, en menor medida, Ratones Paranoicos o Los Guarros. En el caso de Patricio Rey y sus Redonditos de Ricota, con el correr del tiempo fueron convocando seguidores de sectores populares y continuaron reivindicando la producción independiente y la organización de sus recitales frente a una "maquinaria" del rock comercializado.

${ }^{20}$ Organizados por el propio gobierno radical en barrios de Capital Federal o en localidades populares del país.
} 
conciencia de lo que estaban enunciando en sus letras y el modo musical que presentaban para comunicarse. Los nuevos artistas traían ideas y formas artísticas distintas a las de sus predecesores. Compartían los símbolos estilísticos del movimiento de punk y la new wave inglesa, proponían un regreso a la simplicidad rockera y a la relación directa entre los artistas y la audiencia. Al respecto, Andrés Calamaro, por entonces flamante tecladista de Los Abuelos de la Nada, enfatizaba su visión sobre el movimiento: "el rock es nuestra cultura. La cultura de una generación que rechaza la herencia de generaciones anteriores, una herencia de crisis, de sangre, una de las peores del mundo" (1985: 132).

La llamada "revolución pop" trajo consigo una sensación y una discursividad de vigorocidad y alegría generalizada. Como señala el periodista y director de la emblemática revista Pelo, Juan Manuel Cibeira, la democracia contenía una intensidad débil aún y "la consigna era la fiesta perpetua para evadirse lo más rápido posible del insoportable legado de la dictadura, desnudado finalmente en toda crueldad. Parte de esa fiesta pasaba por sitios como el Parakultural y Paladium" (2014: 264).

\subsubsection{El camino del pop}

El pop-rock o rock-pop de las nuevas bandas se esforzó en desmarcarse del discurso colectivo y opositor que había cumplido el rock durante la dictadura. Estas posturas consiguieron que las figuras emblemáticas del movimiento comenzaran a hablar con desagrado sobre la estética y las propuestas extra-musicales de la camada emergente. En efecto, Litto Nebbia fue uno de los primeros que reaccionó contra aquellos artistas que proponían nuevas estéticas. "Después de Malvinas, además del pop, vino esta suerte de democratita musical (...) No creo que las canciones posteriores a 1973 hayan quedado en la memoria colectiva como las primeras, más allá de algunas excepciones” (Berti, 1994: 111).

En ese sentido, Vila señala que el arribo de la democracia también trajo consigo un enigma, puesto que el rock no tenía muy en claro qué propuesta asumir ni a qué enemigos enfrentar en un contexto de libertad:

En el medio, las variantes son infinitas: transformar al movimiento en algo más que un público que asiste a recitales, creando "Centros de las buenas ondas" que realicen acción comunitaria; seguir jugando a la violencia contra el sistema (Pappo) 
o reinsertar al movimiento en el underground, como única alternativa de evitar la comercialización creciente (Miguel Zavaleta -líder de Sueter-). Todas estas vertientes conviven en un año, 1984, que claramente es de transición; y son intentos de respuesta de un movimiento contestatario ante la apertura del espacio democrático. Una vez desaparecido el régimen militar que exacerbaba las características del "sistema" que el rock siempre criticó, sigue quedando el sistema (1985: 112).

De acuerdo con esto, la clase política de la democracia se desvivió por tener al rock como aliado e intentaron generar acercamientos: con el correr del tiempo, el único movimiento al que la gente de la guitarra eléctrica quiso sumarse sin reservas fue el de los derechos humanos, "una forma distinta de hacer política y fortalecer una democracia..." (D'addario, 2007).

Las líricas del rock argentino del período seleccionado proponían además una disputa tirante con los discursos que respaldaban compromisos políticos o de protesta de los años $_{\text {previos }}{ }^{21}$. Se ratificaban, de algún modo, supuestas nociones despolitizadas o desamparadas políticamente a conciencia, que convocaban cambios relacionales de politización durante la reconstrucción democrática y el propio desarrollo cultural del rock argentino ${ }^{22}$. Se intentaba así, separar las vicisitudes contraídas durante la década del $70 \mathrm{y}$, del mismo modo, se generaban falsas confusiones en torno a lo que se consideraba político, escapista y anti-reflexivo.

\subsubsection{Al calor de las masas}

Las revistas especializadas de rock también fueron ganando su terreno en el período 1983-1986. Tanto Cantarock, Twist \& Gritos y la clásica Pelo se dedicaron a reseñar los orígenes del rock argentino, publicando letras y acordes de canciones, $\mathrm{y}$ entrevistando a las figuras emblemáticas y emergentes del movimiento. La revista $E l$ Porteño, que abordaba temáticas sociales y políticas, también ocupó un espacio

\footnotetext{
${ }^{21}$ Se puede marcar que existe una noción de compromiso político universal y colectivo durante los años 1967 hasta 1975 y uno muy distinto en tiempos de dictadura cívico militar (1976-1983). Aún así, se advierten notables diferencias con el período que se abre a partir del advenimiento democrático.

${ }^{22}$ A modo de ejemplo, cabe resaltar las diferencias establecidas por los discursos de la agrupación Patricio Rey y sus Redonditos de Ricota, quienes no escondían el contenido político de sus intervenciones estéticas.
} 
importante para el periodismo independiente, más allá del rock. De hecho, el suplemento Cerdos \& Peces comenzó a salir en ese semanario y se ubicó en la palestra de los medios contraculturales. Por consiguiente, el rock comenzaba a dar muestras de rentabilidad en otras áreas del mercado.

La más exitosa de estas publicaciones fue Cantarock, que se originó y concluyó en democracia, y llegó a vender más de cien mil ejemplares entre 1984 y 1985. Las notas de Pipo Lernoud, uno de los pioneros del rock y del periodismo alternativo, y de Miguel Grinberg, el historiador por excelencia del movimiento, le dieron un aire contracultural que recordaba a las mejores épocas del Expreso Imaginario, una revista de rock que sobrevivió a la dictadura como espacio simbólico y cultural de resistencia.

Sumado a esto, en 1985 aparecieron el suplemento Sí del diario Clarín y la emisora radial Rock and Pop, dos sucesos que hablaban por sí solos del fenómeno que se venía produciendo en el rock. En este caso, el escritor y periodista Mariano del Mazo ve esta masificación del movimiento rockero de una manera crítica y, a partir de ello, señala que el rock empezó a ser la banda de sonido oficial del sistema (2006: 42).

Como se observa, el momento de la denominada primavera democrática se desarrollaba con creces y las consignas de consolidación democrática que el presidente había repetido durante su campaña todavía encontraban ecos en la sociedad:

La economía iba medianamente bien, las movilizaciones populares habían marcado a fuego a millones de personas que estaban convencidas de que vendrían días mucho mejores y la política de derechos humanos del gobierno parecía aceptable. De hecho, en abril de ese año, en un fallo histórico en el nivel mundial, los máximos responsables de la dictadura 1976-1983 fueron condenados a un conjunto de graves penas por una serie de delitos de lesa humanidad, lo que alegró al grueso de los ciudadanos (Polimeni, 2006: 184).

En tanto, los dos primeros años del gobierno radical se vivenciaban como un hito cultural sin precedentes para el rock y, asimismo, reafirmaba el lugar del pop en el universo de esta cultura:

El pop no es sinónimo de banalidad o artificio, aunque con su nombre se cometan auténticas atrocidades musicales. Es la canción con todos sus atributos: el ritmo, la melodía y la armonía mejor dispuestos: y también la frescura y la espontaneidad. 
Con estos elementos nutrió al rock dándole un envase más acabado donde realizar su mensaje contestatario (Cibeira, 1985: 3).

En ese marco, la efervescencia le ganó la partida al testimonio, y el rock se montó en una cresta de una ola de repercusión con pocos antecedentes. La explosión que se efectuó en 1985 dio pie para que las discográficas y las editoriales conmemorasen los veinte años del rock argentino, reconfigurando, una y otra vez, las nuevas y antiguas historias del movimiento.

Del mismo modo, la convocatoria a recitales de rock organizados por músicos argentinos se encontraba en franco ascenso. Lo mismo sucedió con la venta de discos, tanto de estudio como grabaciones en directo. El rock argentino se encontraba en un momento de éxito supremo en el universo del espectáculo nacional y continuaba por una senda de conquista que lo obligaba a pensarse desde otras fronteras.

\subsubsection{Entre la exportación y el cierre del alfonsinismo}

El pop-rock argentino era considerado demasiado localista hacia 1983 como para ser exportado a un público juvenil latinoamericano que, por otra parte, prefería ritmos bailables por sobre el rock en español. Pero todo cambió hacia mediados de la década del 80 cuando una saludable ola democrática que "inundó el continente pareció sacar a la luz a una generación de gustos más rockeros y al tanto de la historia de esta música en la argentina, aunque fuera a través de los discos y cassettes que habían circulado de modo casi underground durante quince años" (Berti, 1994: 69).

Junto con el promocionado nuevo cine argentino, el rock fue uno de los productos autóctonos que más creció en el período 1983-1989. Las giras de Virus, GIT, Zas y, sobre todo, Soda Stereo provocaron un gran impacto en la región ${ }^{23}$. El rock-pop argentino se convirtió en una referencia ineludible para comprender las manifestaciones artísticas y las prácticas estéticas de los jóvenes urbanos de Latinoamérica. En este sentido, los músicos se ubicaron como portavoces generacionales que, en muchos casos, promovían una liberación de tensiones y de perspectivas políticas en sitios con conservadurismos feroces.

\footnotetext{
${ }^{23}$ De hecho, la incidencia del rock argentino marcó con creces las culturas juveniles de México, Perú, Colombia o Chile (todavía bajo el régimen del dictador Augusto Pinochet).
} 
Del mismo modo, tuvo una presencia muy fuerte en la gira Amnesty Internacional que se cerró en el Estadio de River Plate en 1988, con la presencia de figuras internacionales como Sting, Peter Gabriel, Bruce Springsteen, Tracy Chapman y Youssou N'Dour, y también con la colaboración de Charly García y León Gieco como exponentes locales teloneros. De este modo, el rock argentino se hizo presente desde una radiografía mundial y, del mismo modo, levantó las banderas de los derechos humanos acercándose a las Madres y Abuelas de Plaza de Mayo, inclusive.

Siguiendo esta línea de compromiso político, el núcleo duro de los artistas que habían participado de la oleada post-Malvinas también habían decidido incorporarse fuertemente en la campaña electoral presidencial de 1989 que enfrentaba a Eduardo Angeloz (candidato de la UCR) y Carlos Menem (elegido por el PJ). Por ejemplo, tanto Virus, La Torre, Man Ray o Los Pericos como Charly García y Luís Alberto Spinetta, entre otros, participaron de la gira nacional "Rock por Angeloz", organizada por el creador de la Radio Rock and Pop, Daniel Grinbank, con el propósito de apoyar efusivamente al candidato radical: "El cierre fue en Ferro, con Charly García que arengaba a la multitud: 'Menem never' decía" (Esses y Ver, 2015: 509). Por contrapartida, tanto Memphis, la blusera, como Los Auténticos Decadentes o Litto Nebbia contribuyeron activamente con la campaña del justicialismo, sobre todo en Capital Federal y Gran Buenos Aires.

Este hecho generó algunas divisiones entre los músicos más experimentados y los novatos que estaban renovando el rock-pop argentino durante la segunda mitad de la década del 80. En principio, la participación de los músicos en la campaña electoral generó ciertas discordancias en torno a: la participación por razones económicas, la colaboración por el mero hecho de la difusión a escala nacional, o, en el caso de la mayoritaria contribución a la gira de Angeloz, una situación que develaba un posible temor al peronismo o a la victoria peronista (Berti, 1994: 80).

\subsubsection{Una etapa de desencanto}

No obstante, los años de exportación de la música rock argentina a lo largo del continente latinoamericano se llevaron a cabo en un contexto distinto al del inicio de la democracia. Las expectativas se mostraban más cerca del desencanto que de las ilusiones. El rock de 1986 estaba a años luz de la alegría imperante del período 19831985: 
Argentina, país ciclotímico como pocos, hizo que en sólo dos años, cuando se comprobó que no era tan fácil comer, cura y educar, que era tan fácil limpiar tanta mugre subterránea, que habría que recorrer un largo camino hasta castigar tanto crimen, la negritud y el pesimismo ganaran el horizonte (Fabregat, 2007).

La sensación de alegría y esperanza que había comenzado y se había desarrollado en los primeros tres años de Alfonsín, fue disminuyendo a la par de los conflictos militares, económicos y de las leyes que consagraron la impunidad. El rock acompañó este proceso desde sus distintas perspectivas, primero desde un humor social favorable y luego desde la postulación del desencanto o del nihilismo sobre la democracia:

\begin{abstract}
Alfonsín parecía un papá bonachón y honesto que nos sentaría en las rodillas y nos sacaría las lágrimas con su pañuelo. Capaz de haber metido en la cárcel a esos asesinos, no le iba a temblar la mano si tenía que hacer lo mismo con la resaca que había quedado afuera. Por más revuelo que hicieran y por más que se pintaran la cara. Pero no. Fue amable y diplomático. Hizo un trato e imperceptiblemente puso en marcha el "proceso" de nuevo. Creímos en sus huevos y nos los comimos en la
\end{abstract} Pascua de 1987 (Aira, 1998: 119).

Durante el período 1987-1989, el rock argentino en su conjunto dejó de lado las canciones con sonoridades festivas o discursos líricos alborozados, y comenzaron a advertirse nociones de fracaso y/o ausencias de expectativa en relación con la instancia democrática. El rock argentino empezó a modificar sus discursos de inclinación pop en virtud de un nihilismo que celebraba críticamente y reflexionaba sobre el estado de ánimo optimista de los inicios:

Se fue operando un fin de fiesta simbólico de ese período fugaz, veloz como el arrebato de la cocaína; el festejo llegaba a su fin (...) El rock, que en su vertiente pop lo había festejado, mostró su decepción ante el estado de crisis permanente e hiperinflación, y lo moderno se inflexionó en dark, con un costado más pesimista (Blanco y Scaricaciottoli, 2014: 146).

Cibeira, asimismo, le suma una instancia crítica a este cierre de época y destaca que finalización estrepitosa del gobierno de Alfonsín desnudó también la impotencia la 
lírica y la "falta de creatividad" del rock que se venía advirtiendo desde mediados de 1988: "Esterilidad en las letras, insistencia en la reproducción de modelos sonoros sin ningún contenido original y ausencia de un proyecto ideológico fueron las constantes mostradas por la mayoría de las propuestas" (2014: 237).

En este sentido, el contexto de hiperinflación y las conmociones sociales, políticas y culturales vinculadas con los meses finales del Gobierno de Alfonsín sacudieron fuertemente el ámbito de la escena rock de argentina. El rock argentino, en función de las líricas producidas en dicho contexto, comenzó a establecer cierta pérdida de ideales proyectuales a raíz de las problemáticas económicas del país y la diversificación de enemigos/contrincantes/adversarios posibles: gobierno, políticos, policía, militares, periodismo, empresarios. De este modo, la década siguiente comenzaría en estado de crisis y con un rock de expresión crítica y con un repertorio de canciones que diagramarían lineamientos populares y también particulares, alejándose así de las estéticas pop que habían sido laureadas durante los 80 . 


\section{Capítulo IV}

\section{Recorrido metodológico}

\subsection{La puesta en curso del análisis}

Este capítulo da cuenta del recorrido metodológico propuesto para llevar a cabo un trabajo analítico desde el marco de los estudios del discurso y específicamente, la teoría de la enunciación. Se señalan así las disposiciones constantes del trabajo, en torno a la conceptualización y la puesta en organización práctica de los discursos. En este sentido, el recorrido metodológico detallado expone elecciones, decisiones y motivos de reflexión: por un lado, se precisa la construcción del problema, de los objetivos y las perspectivas que fundamentan el empleo teórico-analítico, en segundo lugar, se resalta la indagación en otras disciplinas de las ciencias sociales: es decir, la vinculación con otros saberes y conocimientos; por último, se explicita la construcción de un corpus analítico determinado y la discriminación de procedimientos analíticos que señalan el tránsito constructivo típico de los estudios del discurso.

Como se mencionó anteriormente, este trabajo de tesis doctoral en comunicación se abordó esencialmente, desde una perspectiva cualitativa. A partir de ello, se consideraron diferentes puntos de vista y se emplearon técnicas y herramientas para la observación, interpretación y reinterpretación del corpus seleccionado, del objeto de estudio en su dimensión global y de la relación con el contexto. El análisis de estos componentes, en consecuencia, implicó adentrarse en el entramado de los vínculos sociales (de los conflictos y las identidades) y comprender las características socioculturales de un proceso histórico, para arribar a niveles de comprensión que escapan a una lectura espontánea.

De esta manera, la realización del análisis discursivo precisó la ubicación de la instancia comunicativa, teniendo en cuenta el contexto y la organización textual. Por ello mismo, el trabajo actual postula un estudio concreto de las piezas discursivas a partir de la contextualización y de la aplicación de ciertas categorías enunciativas que permitieron detectar las huellas subjetivas plasmadas en las líricas y aproximarse así a las intencionalidades y los efectos de sentido correspondientes. 


\subsection{Trayectos metodológicos}

\subsubsection{En torno a los objetivos y los propósitos de la investigación}

Las líricas seleccionadas para el corpus advierten una construcción de libertad postulada como un capital en disputa que propone saberes, luchas y discusiones, y expone distintas formas de concepción que podrían enmarcar las siguientes proposiciones: 1) se habla de liberación en relación a la transición democrática y la retirada militar; 2) se presentan articulaciones cotidianas y aspectos que postulan un abordaje "divertido" de la vida; 3) se advierte un abordaje de la sexualidad y la individualidad en un marco de convivencia democrática) y 4) se aborda una semantización apocalíptica que abre grietas sobre la democracia.

En este sentido, la pregunta inicial de investigación que motivó la presente tesis doctoral ubicó el foco en la tematización de la libertad y su presencia en las líricas que integran el corpus analítico. Al respecto, el análisis discursivo de las letras se realizó a partir de un estudio discursivo-lingüístico que relacionó las letras de las canciones con las condiciones de producción sociales, culturales y políticas en el que fueron elaboradas y provocadas.

Por esta razón, la redacción de los objetivos de la investigación se orientó a partir del desprendimiento de pasos que vincularon a la creación del tema, la pregunta inicial y la construcción del corpus. La construcción del objetivo general apuntó a una instancia general de conocimiento que contiene la intencionalidad básica de la investigación. Por ende, la postulación de objetivos específicos se constituyó para orientar el curso del proceso investigativo.

En consecuencia, el objetivo general propone identificar y analizar la construcción discursiva del ideario de libertad que tematizan las letras del rock argentino durante la transición democrática, desde julio de 1982 hasta junio de 1989. Por su parte, los objetivos específicos permiten articular el estudio concreto de las piezas discursivas destacando así la contextualización y la aplicación de ciertas categorías analíticas lingüísticas y de la Teoría de la Enunciación que permiten detectar las huellas subjetivas plasmadas en las líricas y aproximarse así a las intencionalidades.

Consiguientemente, los objetivos específicos plantean una tematización de la libertad que presentan las letras del rock argentino del período temporal seleccionado, tomando en consideración las marcas y huellas de la subjetividad en el lenguaje; la interpretación 
y el análisis del contexto de transición democrática que construyen las líricas seleccionadas en virtud de la tematización de la libertad; la indagación y la interpretación de las estrategias enunciativas que se articulan en las líricas seleccionadas para el corpus de análisis y que se advierten a partir de referencias, modalizaciones, intertextualidades y cargas valorativas del léxico.

\subsection{La construcción del corpus}

Desde el universo cualitativo, el análisis discursivo se desarrolla como un procedimiento analítico edificado por un corpus de investigación que construye, asimismo, el objeto discursivo de estudio. Ante esto, conviene señalar que la producción del corpus se construye por medio de un contexto socio-histórico y en relación con las características que presentan las líricas como materiales textuales (Conein y Pecheux, 1986). La construcción de este objeto implica también la construcción de una tipología, pues se elige un modo de ver y ello configura un criterio para aunar lo semejante, ya sea por estrategias, por formas, por significados y sentidos; a su vez las jerarquías que es posible establecer dentro de una misma tipología, por la cual se diferenciaría el tipo general y el subtipo, por ejemplo (Fino, 2007: 17).

La constitución del corpus admite la creación de un lugar oblicuo desde donde se observa una infinita complejidad; puesto que se exhiben rasgos significativos con respecto al asunto que se analiza: "En cualquier caso, rasgos que sean, además, significativamente ( ¿afines, cercanos, próximos, ajenos, semejantes, diferentes, homólogos, análogos?) a los de la totalidad mayor a partir de la cual ese inevitable retazo ha sido construido de manera más o menos experimental" (Carbó, 2001: 5).

La realización del corpus se efectúa a partir de las clasificaciones de unidades de sentido, las identificaciones de las disyunciones fundamentales y el rastreo de las asociaciones. En función de ello, la constitución de categorías analíticas admiten una instancia de síntesis y abstracción para poder abarcar consideraciones de orientación global. En sentido adicional, a partir de la diversidad y de la construcción de informaciones diversas, este corpus se construye en virtud de su contrato global de comunicación, sus variantes más específicas y sus posibilidades de revisar lo que sucede en el nivel de la construcción discursiva (Charaudeau, 2004).

En función de ello, la constitución del corpus de este trabajo se fundó a partir de líricas que advierten un marco temporal determinado (1982-1989) y que tematizan a la libertad 
en sus discursos. El recorte del corpus que se presenta en la tesis derivó de la selección de las distintas agrupaciones/bandas/artistas que sobresalieron (masiva o públicamente) en la escena cultural argentina post-dictatorial y que, del mismo modo, reflexionaron sobre las nociones de la libertad.

Al respecto, la conformación del corpus analítico se vinculó con el posicionamiento teórico establecido en el inicio, puesto que el material ha sido categorizado a partir de nociones en común; contradicciones, comparaciones e identificaciones según el objetivo de análisis global enunciado. La elección refirió a los artistas del rock argentino que formaron sus agrupaciones a partir del año 1980 o iniciaron su etapa solista durante este período y se destacaron por proponer una estética bailable, irónica y pop, que en distintas instancias reivindicaban la dimensión corporal y la sexualidad como nueva postura temática.

En consecuencia, el rastreo correspondiente que se realizó presenta un corpus de 40 (cuarenta) letras que permitieron alcanzar y admitir un mapa heterogéneo y detallado del universo cancionístico del rock-pop argentino de la década del 80. De acuerdo con ello, para el recorte se tomaron en consideración un máximo de 3 (tres) canciones por artista, accediendo así a una trama tematizante de la libertad diversa y de comparación enriquecedora. La elección de las líricas correspondió a una búsqueda de repertorios equivalentes en relación con la construcción de la libertad.

Por esto mismo, la distinción de las canciones se vinculó con la propia postura de los artistas anteriormente definidos y se distinguieron por la tematización libertaria que presentan en su discurso, teniendo en cuenta la referencia con la última dictadura militar, la defensa del concepto en virtud con la democracia, el enlazamiento con las instancias cotidianas del nuevo estado de derecho, el ideario de escape y/o huida en un entorno democrático $\mathrm{y}$, finalmente, las enunciaciones tensionantes con la identidad juvenil en un contexto de transición.

En función de lo antedicho, en el siguiente cuadro, se pueden visualizar el año de publicación de las líricas, el nombre de las mismas, los intérpretes, lugar de origen y el subgénero del rock argentino al que pertenecen, desde su orientación $p o p^{24}$.

\footnotetext{
${ }^{24}$ Las canciones con letra completa están incluidas en el anexo de la presente tesis doctoral.
} 


\begin{tabular}{|c|l|l|l|l|}
\hline $\begin{array}{c}\text { Año de } \\
\text { publicación } \\
\text { de la lírica }\end{array}$ & Nombre de la canción & \multicolumn{1}{|c|}{ Intérprete } & Lugar de origen & $\begin{array}{c}\text { Subgénero al } \\
\text { que pertenecen }\end{array}$ \\
\hline $\mathbf{1 9 8 2}$ & "Inconsciente colectivo" & Charly García & $\begin{array}{l}\text { Ciudad Autónoma } \\
\text { de Buenos Aires } \\
\text { (CABA) }\end{array}$ & Rock/Pop \\
\hline $\mathbf{1 9 8 2}$ & $\begin{array}{l}\text { "Ahora estoy en } \\
\text { libertad" }\end{array}$ & Celeste Carballo & Coronel Pringles & Folk/Rock/Pop \\
\hline $\mathbf{1 9 8 2}$ & "Ir a más" & $\begin{array}{l}\text { Los Abuelos de la } \\
\text { Nada }\end{array}$ & CABA & Rock/Pop \\
\hline $\mathbf{1 9 8 2}$ & "Buenos cimientos" & La Torre & CABA & Hard Rock/Pop \\
\hline $\mathbf{1 9 8 2}$ & "Una canción diferente" & Celeste Carballo & Coronel Pringles & Folk/Rock/Pop \\
\hline $\mathbf{1 9 8 3}$ & "Su, me robaste todo" & Zas & CABA & Rock/Pop \\
\hline $\mathbf{1 9 8 3}$ & "No me dejan salir" & Charly García & CABA & Rock/Pop \\
\hline $\mathbf{1 9 8 3}$ & "Viaje a la libertad" & La Torre & CABA & Rock/Pop \\
\hline $\mathbf{1 9 8 3}$ & "Ellos nos han separado" & Virus & La Plata & Rock/Pop \\
\hline $\mathbf{1 9 8 3}$ & "Jugando Hulla-Hulla" & Los Twist & CABA & Rock/Pop \\
\hline $\mathbf{1 9 8 3}$ & "Yo soy tu bandera" & $\begin{array}{l}\text { Los abuelos de la } \\
\text { CABA }\end{array}$ & Rock/Pop \\
\hline & & Nada & & \\
\hline
\end{tabular}

\begin{tabular}{|c|c|c|c|c|}
\hline 1984 & $\begin{array}{ll}\text { "Libertad } & \mathrm{de} \\
\text { pensamiento" } & \end{array}$ & $\begin{array}{l}\text { Alejandro } \\
\text { Lerner }\end{array}$ & CABA & $\begin{array}{l}\text { Pop/Rock/Balad } \\
\text { a }\end{array}$ \\
\hline 1984 & "Demoliendo hoteles" & Charly García & CABA & Rock/Pop \\
\hline 1984 & “¿Dónde estás guardada?” & $\begin{array}{ll}\text { María } & \text { Rosa } \\
\text { Yorio } & \end{array}$ & CABA & $\begin{array}{l}\text { Pop/Rock/Balad } \\
\text { a }\end{array}$ \\
\hline 1984 & $\begin{array}{l}\text { "Manifestación } \\
\text { escépticos" }\end{array}$ & Sueter & CABA & Pop/Rock \\
\hline 1984 & "Dietético" & Soda Stereo & CABA & Rock/Pop \\
\hline 1985 & "Sin Disfraz" & Virus & La Plata & Rock/Pop \\
\hline 1985 & "Foto de una jaula" & Sueter & CABA & Pop/Rock \\
\hline 1985 & $\begin{array}{l}\text { "Alguna vez voy a ser } \\
\text { libre" }\end{array}$ & Fito Páez & Rosario & Rock/Pop \\
\hline 1985 & "Soy donde voy" & GIT & CABA & Rock/Pop \\
\hline 1986 & "Hay que hacer la cola" & $\begin{array}{l}\text { Viudas e Hijas de } \\
\text { Roque Enroll }\end{array}$ & CABA & Pop/Rock \\
\hline 1986 & "Acción y reacción" & La Sobrecarga & Trenque Lauquen & $\begin{array}{l}\text { Rock/Pop } \\
\text { Post-Punk }\end{array}$ \\
\hline 1986 & "Héroes anónimos" & Metrópoli & CABA & $\begin{array}{l}\text { Rock/Pop } \\
\text { Post-Punk }\end{array}$ \\
\hline
\end{tabular}




\begin{tabular}{|l|l|l|l|l|}
\hline $\mathbf{1 9 8 6}$ & $\begin{array}{l}\text { "Nunca podrás sacarme } \\
\text { mi amor" }\end{array}$ & Fito Páez & Rosario & Rock/Pop \\
\hline $\mathbf{1 9 8 6}$ & "Prófugos" & Soda Stereo & CABA & Rock/Pop \\
\hline $\mathbf{1 9 8 6}$ & "Nada me detiene" & La Torre & CABA & Hard Rock/Pop \\
\hline $\mathbf{1 9 8 6}$ & "Planeta Agua" & Los Encargados & CABA & Pop/Rock/Tecno \\
\hline $\mathbf{1 9 8 6}$ & "Los viejos vinagres" & Sumo & $\begin{array}{l}\text { Córdoba- } \\
\text { Hurlingham }\end{array}$ & $\begin{array}{l}\text { Rock/Pop } \\
\text { Post-Punk }\end{array}$ \\
\hline
\end{tabular}

\begin{tabular}{|c|c|c|c|c|}
\hline 1987 & "Libre vivir" & $\begin{array}{l}\text { Miguel } \\
\text { Mateos/Zas }\end{array}$ & CABA & Pop/Rock \\
\hline 1987 & "El rosario en el muro" & $\begin{array}{l}\text { Don Cornelio y la } \\
\text { Zona }\end{array}$ & CABA & $\begin{array}{l}\text { Rock/Pop } \\
\text { Post-Punk }\end{array}$ \\
\hline 1987 & $\begin{array}{l}\text { "Yo no me sentaría en tu } \\
\text { mesa" }\end{array}$ & $\begin{array}{l}\text { Los Fabulosos } \\
\text { Cadillacs }\end{array}$ & CABA & Rock/Ska/Pop \\
\hline 1987 & "Rodillas" & María Rosa Yorio & CABA & Pop/Rock \\
\hline 1988 & "Siento llegar" & Fabiana Cantilo & CABA & Rock/Pop \\
\hline 1988 & "Guitarras blancas" & $\begin{array}{ll}\text { Los } & \text { Enanitos } \\
\text { Verdes } & \end{array}$ & Mendoza & Pop/Rock \\
\hline 1988 & "Ocho ríos" & Los Pericos & CABA & $\begin{array}{l}\text { Pop/Rock/Regga } \\
\text { e }\end{array}$ \\
\hline 1988 & "Enjaulados" & Fricción & CABA & $\begin{array}{l}\text { Rock/Pop } \\
\text { Post-Punk }\end{array}$ \\
\hline 1988 & "Espirales" & $\begin{array}{l}\text { Don Cornelio y la } \\
\text { Zona }\end{array}$ & CABA & $\begin{array}{l}\text { Rock/Pop } \\
\text { Post-Punk }\end{array}$ \\
\hline 1988 & "Salgamos a la calle" & Man Ray & CABA & Pop/Rock \\
\hline 1988 & "No me empujes" & Andrés Calamaro & CABA & Rock/Pop \\
\hline 1989 & "Edificios" & La Portuaria & CABA & Pop/Rock \\
\hline
\end{tabular}

La selección de estos exponentes de orientación pop permitió ubicar así, dentro de la amalgama del rock argentino, un abanico de estilos y estéticas que se advierten a partir de:

- las construcciones enunciativas de sus discursos líricos (aspecto fundamental que se atenderá específicamente en el trabajo).

- los estilos experimentados en sus discos (new wave, rock moderno, post-punk, tecno-rock). 
- y las propias trayectorias que exponen geografias y distinciones urbanas particulares (Ciudad Autónoma de Buenos Aires, Gran Buenos Aires, Interior de Buenos Aires, La Plata, Rosario y Mendoza).

Del mismo modo, el repertorio constituido giró en torno una diversidad ya mencionada que propuso distintos objetivos estéticos y estilísticos, desde el plano del lirismo y la creación del sonido. A modo de organización, es posible diagramar aspectos que permitieron ubicar a los artistas en perspectivas distintivas y propias de los códigos del pop.

Por un lado, se articuló una corriente new wave, bailable, vinculada con una discursividad paródica, construida desde la cotidianeidad y también rupturista en relación con la propia historia del rock argentino:

- GIT, La Torre, Los Abuelos de la Nada, Los Enanitos Verdes, Los Twist, Soda Stereo, Sueter y Virus (vinculados a aspectos bailables y fragmentarios desde el plano del contenido textual y a partir de sus diferencias); Los Fabulosos Cadillacs, Los Pericos, La Portuaria y Man Ray (relacionados a agrupaciones formadas en la nueva democracia y enlazados con sonoridades $s k a^{25}, \operatorname{reggae}^{26}$ y world $_{\text {music }}^{27}$ ); Maria Rosa Yorio, Fabiana Cantilo y Viudas e Hijas de Roque Enroll (vinculadas con lo bailable, lo paródico y la exposición de la feminidad)

\footnotetext{
${ }^{25}$ El ska es un género musical de ritmos jamaiquinos, con una intencionalidad más vehemente que el reggae, originado a finales de la década de $50 \mathrm{y}$ divulgado fuertemente durante la segunda mitad de los 60. Sus líricas, particularmente, contienen discursos contra-hegemónicos y críticos que abordan cuestiones raciales, políticas y socio-económicas.

${ }^{26}$ El reggae es un género musical desarrollado en Jamaica hacia mediados de la década del 60 . Se caracteriza por contemplar un ritmo cálido y pausado, y por integrar líricas que plantean discursos de pacificación, religión, desprejuicio y protesta contra los dominios imperantes de los gobiernos coloniales. ${ }^{27}$ La world music refiere a las músicas diversas o globales que pueden integrar una manifestación artística musical. El género procura contener un concepto amplio que incluye tradicionalismos, localismos y folclores determinados en un universo integrador. Si bien su categorización es contemplada de un modo positivo en ciertas manifestaciones artísticas, el término también remite al modo anglosajón de calificar quizás asimétricamente los sonidos africanos, latinoamericanos o escandinavos.
} 
Por otra parte, se apreció un desenvolvimiento artístico en plan solista que, con diferencias, construye en las líricas un abordaje cotidiano desde lo discursivo y/o recorre una invitación al baile desde lo sonoro:

- Charly García, Andrés Calamaro y Fito Páez (apelando a un lirismo de orientación testimonial y sonoridad dinámica); Celeste Carballo y Alejandro Lerner (empleando una producción folk ${ }^{28}$, melódica y romántica, en algunas instancias)

En última instancia, se presentaron las perspectivas denominadas post-punk ${ }^{29}$, tecnopop $^{30}$ o de estética $\operatorname{dark}^{31}$ :

- Sumo, Don Cornelio y la Zona, Fricción, La Sobrecarga, Metrópoli y Los Encargados (enlazadas con una visión desaprobatoria y tensionante con la sociedad, desde una orientación pop y matices diversos).

El propósito de esta elección heterogénea se debió a la intención de abarcar los discursos líricos desde las amplias y distintas perspectivas del pop propuestas por el rock argentino. La amplitud y, asimismo, el límite del análisis se efectuaron de acuerdo a una búsqueda de saturación que correspondió con una intención de trabajo exhaustivo e integral.

Por tanto, la tesis postuló un estudio concreto de las piezas discursivas a partir de la contextualización y de la aplicación de categorías analíticas que permitieron detectar las huellas subjetivas plasmadas en las líricas y aproximarse a las intencionalidades.

\footnotetext{
${ }^{28}$ La música folk es un género de origen anglosajón que refiere a los sonidos, principalmente, modernos que incluyen guitarra criolla o acústica y también discursos líricos con tonalidades alegóricas, de protesta y de orientación rural o campestre.

${ }^{29}$ El post-punk es un estilo musical que surgió tras el decaimiento masivo del punk, hacia finales de la década del 70. Su estilo estableció las bases para el rock alternativo y profundizó discursividades de intención nihilista, individual y apocalíptica durante la década del 80.

${ }^{30} \mathrm{El}$ tecno es un género de amplia rotación durante la década del 80, luego de la fiebre de la música disco y la ruptura masiva del punk. El término refiere a la música electrónica, bailable y articulada a partir de sintetizadores y sonidos establecidos por teclados, máquinas o computadoras.

${ }^{31}$ La música dark es un género musical que se instauró en pleno auge del post-punk y el estilo new wave. Se caracteriza por contener líricas que articulan discursos oscuros, introspectivos y de espíritu gótico y extremo en cuanto a las consideraciones sobre la realidad y las experiencias urbanas.
} 
Con respecto a ello, cabe señalar que un corpus nunca se establece definitivamente ni se concluye de un modo tajante, sino, por el contrario, propone una clausura provisional y también transitoria. Es por ello que el trabajo actual se posiciona desde una instancia interpretativa y analítica atravesada por coyunturas ideológicas que trabajan un lineamiento discursivo situado y en absoluto irrefutable.

\subsection{El contexto desde una mirada discursiva}

El análisis discursivo lingüístico de las líricas seleccionadas como corpus se realizó a partir de un recorrido de reconocimiento e interpretación de marcas discursivas que permitieron la formulación de tópicos, ítems y registros determinados, en función de un contexto determinado. Desde esta perspectiva analítica, la comprensión del discurso como espacio de huellas de la enunciación, permitió dar cuenta de un ejercicio del lenguaje y apreciar restricciones genéricas, situacionales o propias de la variedad sociolingüística como imperativos psicológicos o ideológicos (Arnoux, 2006).

No obstante, en relación con lo antedicho, conviene acercar una revisión sobre la definición de contexto para comprender sus instancias complejas y diversas en el universo de las ciencias sociales. Por tanto, desde las consideraciones de Bronisław Malinowski en materia antropológica social hasta los desarrollos de John Frith, Dell Hymes y John Gumperz en la sociología y antropología del lenguaje, la conceptualización del contexto se vinculó de un modo determinante con las atmósferas de sociabilidad y las condiciones de interacción en un entorno social y cultural. A partir de estos lineamientos teóricos, el contexto se constituye en función de dos percepciones:

1) la idea de trasfondo social, cultural y simbólico que compone al evento de habla.

Estas bases refieren a aspectos como el medio ambiente local, la política, las creencias y los empleos figurativos y connotativos de la lengua.

2) la significación de lo inmediato y la referencia a la ubicación y situación en las que tiene lugar un evento de habla o una forma particular de discurso. En este sentido, se incluyen las relaciones e interacciones entre los participantes de la acción comunicativa, los acontecimientos relevantes y recientes, los fines específicos, el significado de lo que se dice o se expresa, y las acciones. 
Hacia mediados del siglo XX, los estudios lingüísticos plantearon la necesidad de incorporar elementos contextuales en el análisis a fin de entender adecuadamente el uso de una lengua. Al respecto, la presencia de Roman Jakobson y se su orientación estructuralista en estudios de comunicación permitieron comprender al contexto como uno de los elementos necesarios para tener en cuenta en explicaciones sobre el funcionamiento del lenguaje: "Para que sea operante, el mensaje requiere un contexto de referencia (un «referente» según otra terminología un tanto ambigua) que el destinatario pueda captar, ya verbal, ya susceptible de verbalización" (Jakobson, 1960: $352)$.

De acuerdo con Calsamiglia y Tusón, el contexto es un concepto crucial y definitorio del ámbito de la pragmática y del análisis del discurso, ya que su consideración en la descripción y el análisis de los usos lingüísticos marca la línea divisoria entre los estudios discursivos y los puramente gramaticales (1999: 108). Dado este carácter central, el discurso, como práctica social, se articula a partir de un empleo lingüístico contextualizado. La apreciación del contexto entonces, se define a partir de las estructuras sociales, políticas, culturales e históricas en las que tienen lugar los correspondientes acontecimientos comunicativos, constituidos desde una mirada discursiva.

Siguiendo esta línea, la perspectiva discursiva comprende la presencia de un hablante que construye piezas textuales que presentan propósitos y que vinculan dialécticamente con el contexto (lingüístico, local, cognitivo y sociocultural). Ante esto, resulta relevante remarcar que en todo acto de lenguaje, existe una situación de comunicación que se significa a partir del contexto y la situación en la cual se inscribe.

El concepto de contexto tiene un rol preponderante en los estudios del discurso porque propone, desde una instancia pragmática o discursivo-textual, la incorporación de datos contextuales en la descripción lingüística. La observación del contexto entonces, permite tener en cuenta el marco en el que se manifiestan dichas piezas discursivas. Y admite la comprensión de enunciados que se desarrollan de un modo contextual. Al respecto, los componentes del contexto, pertenecientes a rasgos o destacados a partir de situaciones implícitas o sobrentendidas, organizan un lugar interpretativo construido por pistas e indicios aportados por los propios hablantes, que contribuyen a construir el contexto adecuado (Calsamiglia y Tusón, 1999: 18).

En términos lingüísticos, el contexto es entendido como la estructura de aquellas propiedades de la situación social que son pertinentes y relevantes para la producción y 
la comprensión de los discursos. Se configura así como un elemento constituido por el discurso que se vincula dialécticamente con lo social y se desarrolla en el universo social.

Los rasgos del contexto atraviesan la discursividad, definiendo el espacio y el tiempo de las situaciones, las acciones en curso (incluyendo los discursos y sus géneros), los participantes en roles variados, comunicativos, sociales o institucionales, al igual que sus representaciones mentales: objetivos, conocimientos, opiniones, actitudes e ideologías (Van Dijk, 1999: 31).

En consecuencia, el concepto de contexto se caracteriza como la reconstrucción teórica de una serie de rasgos de una situación comunicativa. Sobre todo de aquellos rasgos que son parte integrante de las condiciones que permiten que los enunciados den resultados como actos de habla. Se aborda así una especificación vinculante entre texto y contexto que extienden ciertos rasgos textuales que constituyen aspectos de contexto y determinaciones de la estructura (Van Dijk, 1978: 93).

El contexto no propone una realidad social objetiva ni una instancia social real, sino articula constructos subjetivos relevantes en determinados escenarios sociales y/o epocales. Se define así según las formas en que los usuarios del lenguaje interpretan o definen las propiedades discursivas mediante estructuras, modelos, géneros, participantes y léxicos que reconocen en una situación social determinada. En este sentido, las acciones, las interacciones y las prácticas sociales que se verifican por medio del discurso son también una parte relevante del contexto.

Por tanto, la producción del discurso y la comprensión en particular dependen de las propiedades relevantes de la situación comunicativa de carácter subjetivo, es decir, de los contextos:

Los contextos no están "ahí afuera", como las situaciones sociales, sino 'aquí adentro'; es decir, en la mente de los usuarios de la lengua (...) Es decir, cuando los usuarios de la lengua prestan atención a dichas propiedades y las encuentran relevantes para lo que dicen o escriben (o escuchan o leen). No es el hecho de ser hombre o mujer, es decir, el género, lo que influye en lo que decimos; sino nuestras interpretaciones o construcción de dichos roles sociales (Van Dijk, 2004: 13).

En la definición de contexto, se incluyen los textos posibles y el entorno o situación de comunicación que incluye creencias, conocimientos particulares, lenguajes empleados 
narraciones del mundo. Se constituye como un concepto decisivo en términos pragmáticos y analíticos del discurso porque, como se inició previamente, el contexto ocupa un lugar específico y destacado en investigaciones de las ciencias sociales. Tomando en consideración esta instancia discursiva, Calsamiglia y Tusón señalan cuatro parcelaciones que sirven para encuadrar una distinción didáctica y para destacar las correlaciones que integra la definición de contexto: puede advertir situaciones espacio temporales, resaltar una demarcación situacional e interactiva entre hablantes; subrayar aproximaciones socioculturales e indicar cogniciones sociales de una determinada época (Calsamiglia y Tusón, 1999: 108):

A raíz de la complejidad del concepto, Levinson propone una instancia constitutiva sobre el contexto, desde el análisis discursivo:

\begin{abstract}
¿A qué podemos llamar entonces contexto? (...) Lyons se atreve a enumerar los siguientes (1977a: 574), además de los principios universales de la lógica y del uso del lenguaje: i) conocimiento del papel y de la posición (donde el papel abarca el papel en el evento discursivo como hablante o como destinatario y el papel social y la posición abarca nociones del nivel social relativo), ii) conocimiento de la situación espacial y temporal, iii) conocimiento del nivel de formalidad, iv) conocimiento del medio (aproximadamente el código o estilo apropiado a un canal, como la distinción entre variedades escrita y hablada de una lengua), v) conocimiento del contenido adecuado, vi) conocimiento del campo adecuado (1983: 19-20).
\end{abstract}

Por consiguiente, la consideración del contexto exige poner en práctica la observación del marco en el que se elaboran las líricas que integran el corpus. Los procedimientos analíticos, por su parte, permiten recoger, describir y analizar el discurso, desde una dimensión enunciativa. Así, es posible aprehender fenómenos en los que los usos lingüísticos se superponen y se relacionan con las prácticas socioculturales de las vivencias en sociedad. Por esto mismo Bonnin remarca que:

La determinación de las propiedades relevantes del contexto de un discurso no se puede llevar a cabo desde el punto de vista de la lingüística sino desde su relación con la ciencia social que provea el marco interpretativo que le da materialidad socio-histórica al texto. Ambas corrientes difieren tanto en términos metodológicos como terminológicos. Sin embargo, comparten algunos presupuestos básicos 
acerca de la definición del objeto discurso como la articulación compleja de una superficie lingüística o textual con las condiciones extralingüísticas que la hicieron posible (2011: 10).

Esta última instancia, que se presenta diversa y compleja, se encuentra interrelacionada y dispuesta a la perspectiva contextual. Se sostiene así la imposibilidad de realizar un análisis discursivo sin tener en cuenta las condiciones de producción, reproducción y circulación que hacen posible el comentario o la opinión en un determinado momento de la discursividad social.

\subsection{Procedimientos analíticos}

La selección de huellas discursivas, en el caso de este trabajo, se efectuó a partir de un proceso de relevamiento y estudio mediado por categorías analíticas que advirtieron fenómenos recurrentes y relevantes en distintos rasgos discursivos. Lo importante de dicha opción de huellas refirió a indicios reveladores de regularidades significativas en relación con la tematización de la libertad. En función de ello, los procedimientos analíticos permitieron estudiar la tematización enunciativa de la libertad, la referencia deíctica e indicial, las propiedades polifónicas e intertextuales y las modalidades del enunciado y la enunciación.

Este repertorio de categorías seleccionadas diagramó también parámetros contextuales que permitieron analizar la tematización de la libertad que circula en las líricas escogidas para el corpus. En este sentido, aspectos de la construcción del sujeto discursivo y de la inscripción del sujeto en sus enunciados, como la deixis, la modalización y la polifonía, contribuyeron a delimitar el modo en el que el empleo de elementos de la lengua manifiesta las implicaciones del enunciador y los enunciatarios.

\section{a) Sobre la funcionalidad de la tematización}

El análisis del lenguaje como expresión y como comunicación, desde la dimensión discursiva y enunciativa, advierte la presencia de una intencionalidad del sujeto hablante. De este modo, se aprecia un empleo estratégico del lenguaje, a fin de organizar los enunciados y configurar verbalmente el discurso. El proceso implica 
decisiones previas sobre la pertinencia a comunicar y el modo de expresión que dispone la lengua determinada.

Sobre este punto, la perspectiva sistémica y funcional analiza el ordenamiento de los mensajes en relación con la forma de distribución de la información. Halliday y Mathiessen (1985, 2004), Firbas (1992) y Gutiérrez Ordóñez (1997), entre otros, sostienen que en la construcción del mensaje se molde lo que el hablante piensa que el destinatario necesita conocer de su visión contextual. Así, la estructura temática otorga a las cláusulas su carácter binario como unidad discursiva, cuyo "Tema" (o soporte) constituye el punto de partida del mensaje y el rema (o aporte), su desarrollo.

Al respecto, el fenómeno que deriva del "Tema" y es conocido como "tematización" advierte un elemento a resaltar, pronunciado con una intensidad reiterada y focalizado en relación con el sentido que se pretende general. En la organización textual, el elemento tematizado fomenta un tópico de abordaje que expone un relato persistente, tanto de un modo explícito como implícito.

El procedimiento de la tematización, supone un asunto de atención insistida, que subyace una importancia apropiada, centralizada a partir de la significación y la trascendencia discursiva. Por esta razón, el espectro de la tematización anuncia, compone, prolonga y/o clausura un tema o un tratamiento conceptual asumido como marco articulador y se relaciona con el modo en que los hablantes organizan el discurso: "Por un lado, la tematización se examina como una construcción gramatical que expresa la función tema en cuanto marca, 'aquello de lo que se trata' el enunciado (...) Por otro, los referentes discursivos manifiestan distintos grados de novedad informativa" (Hidalgo, 2003: 36).

Justamente, esta dimensión temática construye representaciones y tramas a partir de contribuciones y desarrollos en lo que se refiere a la propuesta, mantenimiento y/o cambio de dicho contenido tematizado (Calsamiglia y Tusón, 1999: 65). Así, es posible manifestar que el proceso de tematización resulta posible si se lo orienta hacia la acumulación de conceptos colindantes; en la medida en que se produce una convergencia tópica; y en virtud de la propagación de una situación conceptual referida. En este sentido, resulta útil desplegar un cuadro acerca de las temáticas frecuentemente abordadas en las letras del rock argentino desde sus inicios hasta la actualidad, inclusive. De un modo histórico, los puntos semánticos constituidos en las líricas se relacionan con la ciudad, el sistema, la sociedad adulta, la libertad colectiva/individual y un rasgo melancólico muy en la línea del tango y los arrabales (Di Marco, 1994: 39-40). 
Si bien no existen inventarios definitivos, es posible diagramar oposiciones como ciudad/campo, opresión/liberación o materialismo/espiritualidad, y apreciar también distinciones de ejes vinculadas con la locura, la conciencia social, la sensibilidad o la autenticidad.

Al respecto, Claudia Kozak (1990) divide la determinación poética del rock argentino en temáticas generales que lo recorren durante sus primeros veinticinco años de historia: 1) Proyectos utópicos (utopías campestres; fabulas de liberación y de amor; 2) Manifestaciones de oposición (canción de protesta y crítica a las instituciones; 3) Retratos urbanos; 4) Palabras (sentidos disperso, non sense); y 5) Canciones de sobrevivientes (desaparecidos, Malvinas, desencantados con la sociedad, desencantados y cínicos).

Continuando esta idea, la búsqueda de la tematización en la actual tesis doctoral refirió a un problema de actuación lingüística, tomando en consideración el modo en el que los enunciados fueron planificados y organizados con una intencionalidad particular. A partir de la puesta en común del material tematizado, fue posible analizar un repertorio de estrategia discusiva que dio cuenta del tratamiento enunciativo y la estructura correspondiente. El concepto de libertad, entonces, se comprende como un elemento tematizado en las líricas y como un tópico que admitió la apertura interpretaciones en relación con los contextos y los marcos enunciativos.

\section{b) Sobre la referencia deíctica}

Desde su definición particular, los elementos deícticos organizan el tiempo y el espacio, y sitúan a los participantes y a los propios elementos textuales del discurso. La identificación de deícticos permite advertir los planos contextuales que se enuncian en las líricas, señalar los tiempos y las personas del discurso que conviven en el escenario de comunicación.

Los deícticos "son las unidades lingüísticas cuyo funcionamiento semántico-referencial (selección en la codificación, interpretación en la decodificación) implica tomar en consideración algunos de los elementos constitutivos de las situación de comunicación" (Kerbrat-Orecchioni, 1986: 48). Precisamente, su significado concreto depende plenamente de la situación de enunciación, de quién las pronuncia, a quién, cuándo y dónde. No se trata de un simple mecanismo obligatorio del hablante, sino que, en la 
libertad de expresarse que tiene todo sujeto mediante una lengua, se incluyen los efectos de sentido.

Los deícticos suelen formar clases cerradas: principalmente, los pronombres, ciertos adverbios y los morfemas verbales de persona y tiempo (también algunos verbos, adjetivos). Por lo tanto, se seleccionaron tres tipos de deixis para llevar a cabo el análisis: deixis personal, espacial y temporal.

\begin{tabular}{|c|c|c|c|}
\hline Deixis & \multicolumn{2}{|c|}{ Contexto de la enunciación } & Escenario del "mundo \\
\hline Personal & $\begin{array}{l}\text { Yo (mío) } \\
\text { Nosotros/as } \\
\text { (nuestro) } \\
\quad \text { Nosotros }\end{array}$ & $\begin{array}{l}\text { Tu/usted/vos } \\
\text { (tuyo/suyo) } \\
\text { Nosotros } \\
\text { Ustedes } \\
\text { (suyos) }\end{array}$ & $\begin{array}{l}\text { El, Ella, Ellas/os } \\
\text { (Suyo) }\end{array}$ \\
\hline Espacial & Aquí/acá/este/a/o & Ahí/ese/a/o & Allí/allá/Aquel/aquella/o \\
\hline Temporal & $\begin{array}{l}\text { Ahora (hoy, ayer, } \\
\text { mañana) }\end{array}$ & $\begin{array}{l}\text { Ahora (hoy, ayer, } \\
\text { mañana) }\end{array}$ & $\begin{array}{l}\text { Entonces } \\
\text { (Antes/después) }\end{array}$ \\
\hline
\end{tabular}

La deixis personal señala a las personas del discurso, las presentes en el momento de la enunciación y las ausentes en relación a aquellas. A través de los deícticos de persona, se seleccionan los participantes en el evento. Pero esa selección es flexible y puede cambiar, puesto que se advierten a partir de los pronombres personales, los pronombres posesivos y los morfemas verbales. Quien habla es el yo, sin duda, pero a través de la segunda persona se puede seleccionar a diferentes interlocutores, de forma individual o colectiva, para ellos habrá que tener en cuenta a quien se nombra con la tercera persona (también de forma individual y colectiva).

Por su parte, la deixis espacial organiza el lugar en el que se desenvuelve el evento comunicativo y señala los elementos de lugar en relación con el espacio que funda el hablante como sujeto de la enunciación. Cumplen esta función los adverbios o perífrasis adverbiales de lugar (aquí o acá) y demás.

En consecuencia, la deixis temporal, a su vez, señala los elementos temporales, tomando como referencia el momento de la enunciación. Se expresa mediante verbos, adverbios 
o expresiones temporales, que remiten siempre al presente, en tanto instancia de enunciación.

En el presente trabajo, la categoría de la deixis involucró la codificación y gramaticalización de los rasgos de la situación de enunciación presentes en las líricas. Los elementos deícticos se apreciaron en los verbos, adverbios, pronombres demostrativos, posesivos y personales articulados en las líricas. De este modo, el estudio de la deixis permitió analizar la referencia contextual y la dimensión pragmática del sentido de los discursos de las líricas.

En efecto, cabe destacar la función apelativa que convoca la lírica de rock porque se potencia a partir del empleo de deícticos personales y verbos imperativos, inscriptos como indicaciones en el texto verbal. De esta manera, se instituye una vinculación entre un locutor y un interlocutor que subraya un entramado textual, de perspectiva dialógica en relación a tres personas del discurso.

Por un lado, un yo puede ser construido desde la enunciación, que se comporta como locutor y se responsabiliza del contenido textual. Desde un plano habitual, es posible introducir al locutor y/o hablante como testigo de los hechos que narra o como portavoz fundamental de protagonistas generacionales. En segundo término, se advierte la presencia de un $t \dot{u}$-receptor-interlocutor que es representado discursivamente mediante referencias distintivas, y que se postula desde dos instancias convocantes: el destinatario de la canción y el alocutario propio del texto (el referente intra-textual). En última instancia, es posible referir a una tercera persona que se diferencia de la construcción del tú y del yo, y que se posiciona como un destinatario oposicional que actúa contra ambos. Así, el nosotros, al que representa el intérprete, se configura como la voz de la protesta contra un elemento opresor representado por la tercera persona (Vela Delfa, 2014: 5).

\section{c) Modalidades de enunciación y de enunciado}

Tanto en el universo de los estudios de los lenguajes como en la lingüística y el análisis del discurso, la cuestión de la modalidad está ligada a las estrategias enunciativas que provocan efectos de sentido. Por esto mismo, resulta fundamental la manera en la que se posiciona el sujeto de la enunciación frente al mundo que construye y procura representar en su discurso. 
En otras palabras, la modalidad se ubica como la expresión, huella o marca del sujeto de la enunciación respecto de su enunciado. En el caso del presente trabajo, la dimensión discursiva de la modalidad refirió a la expresión verbal o no verbal de la visión del locutor respecto al contenido de sus enunciados y el modo de decir y/o articular en la lírica de rock.

La modalidad podría considerarse entonces, como una expresividad en la que el locutorhablante considera lo dicho, emplea distintos modos de expresarse y así establece una relación coherente entre su lugar como productor de discurso y los enunciados que emite. Las operaciones expresan la actitud y la posición que toma el locutor en torno a sus enunciados.

En función de ello, Emile Benveniste estudia el proceso de elaboración de un enunciado a través de lo que denomina los caracteres formales de la enunciación que se erigen en torno al momento en sí, las situaciones donde se realiza y los elementos que contribuyen en su construcción. Dicho proceso, admite la existencia de un locutor que reduce al que habla en su habla y demanda la presencia de un alocutario (Secul Giusti, 2015: 87).

La modalización, por consiguiente, se coloca como un concepto problemático que se vincula con los modos de decir algo a alguien y la actitud que adopta el locutor ante lo que dice: refiere a expresión verbal o no verbal de la visión del hablante respecto del contenido de sus enunciados y de la enunciación misma.

Por tanto, Benveniste señala que la enunciación puede definirse en relación con la lengua, como un proceso de apropiación: "El locutor se apropia del aparato formal de la lengua y enuncia su posición de locutor mediante indicios específicos, por una parte, y por medio de procedimientos accesorios, por otra" (Benveniste, 1987: 84-85). Así, el hablante (locutor) está en relación constante y necesaria con su enunciación a través de formas específicas.

Estas últimas, para el autor, se vinculan con pronombres personales, demostrativos, formas temporales, y una diversidad de funciones que relacionan al locutor con el interlocutor (interrogación, intimación, aserción). Por ello mismo, el enunciador se sirve de la lengua para influir de algún modo sobre el comportamiento del otro, a través de la aserción (considerada como un enunciado modalizado que apunta a comunicar una certidumbre), la interrogación (que es una enunciación construida para suscitar una respuesta) y la intimación (órdenes, llamados, concebidos en categorías como el imperativo o el vocativo), puesto que implican una relación inmediata entre el locutor y el interlocutor (1971: 87). 
Maingueneau, con respecto a las modalidades, realiza algunas precisiones terminológicas. Por ello mismo, comienza citando y comentando lo propuesto por André Meunier (que a su vez se inspira en Halliday), quien clasifica dos tipos de modalidades: modalidades de la enunciación y modalidades del enunciado.

Al respecto, Maingueneau sostiene que la modalidad de la enunciación define la modalidad en relación con el sujeto hablante y "caracteriza la forma de la comunicación entre enunciador y destinatario (imperativa, interrogativa, declarativa, exclamativa)" (1981: 132). Es decir que implican una relación social, entre los integrantes de la enunciación porque la relación es primariamente una relación de interacción y determinan así el tipo de comunicación que se da entre el hablante y el interlocutor.

\begin{tabular}{|c|c|}
\hline $\begin{array}{l}\text { Modalidades } \\
\text { de } \\
\text { enunciación }\end{array}$ & Definición \\
\hline $\begin{array}{l}\text { Declarativas- } \\
\text { Asertivas }\end{array}$ & $\begin{array}{l}\text { Expresan la relación interpersonal a partir de la cual el hablante da una } \\
\text { perspectiva asertiva de lo que dice, presenta el enunciado como algo cierto. El } \\
\text { locutor reconoce algo cierto en el enunciado y orienta al interlocutor hacia la } \\
\text { adhesión y la construcción de lo real. }\end{array}$ \\
\hline Interrogativos & $\begin{array}{l}\text { La interrogación implica el deseo del enunciador de obtener una respuesta por } \\
\text { parte del enunciatario. En el caso de las preguntas retóricas, naturalmente, el } \\
\text { efecto de sentido es diverso porque el interrogante implica una respuesta en el } \\
\text { propio enunciado. }\end{array}$ \\
\hline Imperativas & $\begin{array}{l}\text { El hablante hace saber al alocutario su deseo o necesidad de que efectúe una } \\
\text { determinada acción. El locutor busca recibir información y toma una actitud } \\
\text { de orden o de interpelación dirigida al interlocutor. El modalizador típico del } \\
\text { enunciado imperativo es el modo verbal. No obstante, se incluyen también en } \\
\text { esta categoría las construcciones con auxiliares "haber", "deber" y "tener". } \\
\text { Muchas veces el futuro no expresa la temporalidad, sino la modalidad de } \\
\text { probabilidad, de posibilidad o de necesidad, por ejemplo: El estado tendrá que } \\
\text { instar el juicio respectivo, El juez de garantías deberá responder; Habrá } \\
\text { mucho que hacer todavía. }\end{array}$ \\
\hline Exclamativa & $\begin{array}{l}\text { Corresponde a una pronunciación enfática, dado que es posible aplicar el } \\
\text { énfasis en cuestiones imperativas, interrogativas o declarativas-asertivas. }\end{array}$ \\
\hline
\end{tabular}


Del mismo modo, el autor destaca que la modalidad de enunciado hace referencia al sujeto del enunciado y "caracteriza el modo con que el sujeto sitúa la proposición en relación a la necesidad y posibilidad, a la verdad o a los juicios de valor" (1981: 133). Por consiguiente, las modalidades del enunciado corresponden a los aspectos lógicos o apreciativos (vinculados con lo feliz, lo triste, útil) y se distinguen por la forma en que el enunciador ubica su enunciado en relación con la verdad, la falsedad, la seguridad, la probabilidad, la incertidumbre o lo dubitativo (Secul Giusti, 2015: 88).

En este sentido, cabe señalar que esta modalidad se apoya en la relación entre el hablante y su propio enunciado: se trata de la actitud que adopta frente al dictum $^{32}$ y la señalización de una actitud. Los elementos lingüísticos que actúan como modalizadores advierten la relación que se establece entre el hablante y su relación con aquello que sostiene o mantiene.

\begin{tabular}{|c|c|c|}
\hline $\begin{array}{c}\text { Modalidades } \\
\text { de } \\
\text { enunciado }\end{array}$ & Definición & Ejemplos \\
\hline Lógicas & $\begin{array}{l}\text { En relación con la verdad, la falsedad, la } \\
\text { probabilidad, la verosimilitud, la certidumbre. } \\
\text { 1) Dentro de las modalidades de } \\
\text { enunciado lógicas, se distinguen } \\
\text { especialmente aquellas que sitúan el } \\
\text { enunciado del locutor en relación con la } \\
\text { certeza y el refuerzo de una aserción. En } \\
\text { tanto, también se destacan los enunciados que } \\
\text { emplean una restricción de posibilidades y } \\
\text { recubren, así, muchos ámbitos. } \\
\text { 2) También se destacan los enunciados } \\
\text { que emplean una restricción de posibilidades } \\
\text { y recubren, así, muchos ámbitos. }\end{array}$ & $\begin{array}{l}\text { Son pertinentes los } \\
\text { condicionales; el futuro } \\
\text { asociado con la tercera } \\
\text { persona (verbos modales } \\
\text { como "suponer", "creer") y } \\
\text { el auxiliar modal "poder" } \\
\text { combinado con el }\end{array}$ \\
\hline
\end{tabular}

${ }^{32}$ De acuerdo con el lingüista Charles Bally, el dictum refiere a las representaciones de la realidad que se constituyen en contenido preposicional del enunciado y son esgrimidas por un locutor determinado. 


\begin{tabular}{|c|c|c|}
\hline & & $\begin{array}{l}\text { subjuntivo, puesto que } \\
\text { reducen el sentido de } \\
\text { certeza que el hablante } \\
\text { puede imprimir al } \\
\text { enunciado (podrían, serán, } \\
\text { supongo/creo, puede). }\end{array}$ \\
\hline Apreciativas & $\begin{array}{l}\text { Según juicios de apreciación: lo útil, lo feliz, } \\
\text { lo triste. } \\
\text { 1) se advierte una diversidad que resulta } \\
\text { problemática en el momento de clasificar, } \\
\text { aunque se las puede identificar con } \\
\text { enunciados que expresan valoraciones } \\
\text { afectivas o apreciativas respecto de lo feliz, lo } \\
\text { triste, lo útil. El locutor expresa juicios de } \\
\text { valor que lo posicionan en referencia a } \\
\text { categorías de apreciación como lo bueno/ lo } \\
\text { malo, el bien/el mal, lo laudativo/lo } \\
\text { peyorativo. }\end{array}$ & $\begin{array}{l}\text { Este registro de modalidad } \\
\text { se encuentra en relación } \\
\text { directa con el léxico: es } \\
\text { posible encontrar giros } \\
\text { impersonales (es feliz, es } \\
\text { insoportable, es bueno) y } \\
\text { adverbios que acompañan } \\
\text { el enunciado (felizmente, } \\
\text { por desgracia). La } \\
\text { apreciación se vincula con } \\
\text { el acto mismo de la } \\
\text { enunciación cuando el } \\
\text { locutor caracteriza } \\
\text { apreciaciones del mundo y } \\
\text { en virtud de sus } \\
\text { interlocutores. }\end{array}$ \\
\hline
\end{tabular}

A partir de la modalización, las líricas de rock seleccionadas como corpus presentan estrategias de acercamiento a los escuchas/lectores del discurso. En función de ello, las modalidades dan cuenta de la presencia de un hablante en la lírica que actúa como sujeto de la enunciación e incluye la posibilidad de indicación de la existencia del oyente-interlocutor-alocutario. Se despliegan así elementos que denotan modalizaciones de enunciación y/o de enunciado que influyen decisivamente en la producción de la trama enunciativa y la situación comunicativa. Del mismo modo, se advierten enunciaciones que destacan voces de mando o interrogantes, pero también, desde el orden del enunciado, apreciaciones y certidumbres o incertidumbres que construyen un diálogo vinculado con una determinada tematización de la libertad. 


\section{d) Polifonía: presencia de distintas voces en los enunciados}

La noción de polifonía comprende al conjunto de voces articuladas en el discurso y a la integración de las voces de otro en una trama discursiva. La polifonía manifiesta un estado dialógico en la que la huella de lo referido, o la voz de lo otro, organiza el texto o el significado del discurso. La dialogización o puesta en relación de voces convoca un acto de comunicación y de producción discursiva en la que se advierten intertextualidades.

La significación de la polifonía permite abordar intereses e ideologías, hegemonías discursivas y sentidos sociales y culturales constituidos en los discursos. A estas instancias, los conceptos de dialogismo y polifonía, planteados por Bajtín y continuados por Oswald Ducrot o Kerbrat Orecchioni, presumen un reconocimiento de la lengua por las formas sistemáticas de combinación o de sintaxis de las voces integradas en los enunciados en sí mismos (Ramírez Peña, 2008).

Al hablar de polifonía, Kerbrat-Orecchioni, considera las connotaciones como valores asociados, y precisamente se centra en los efectos específicos que generan las rupturas léxicas y semánticas en el funcionamiento global de un texto (Kerbrat-Orecchioni, 1983). A partir del juego connotativo instaurado, la ruptura de la isotopía estilística ${ }^{33}$ se debe a la presencia de unidades que remiten a distintos estados de lengua, o a sincronías diferentes.

En virtud del juego de diversos mecanismos asociativos, otros estratos semánticos se agregan al primero, y constituyen así otros tantos valores connotativos sobreañadidos a la significación denotativa. Por lo tanto, resulta pertinente analizar las líricas en relación a las alusiones, metáforas, ironías y reminiscencias culturales porque permiten advertir una amplia gama de procesos polifónicos.

Las alusiones son comprendidas como asociaciones hechas al pasar, en las que el locutor da por sobrentendida una connivencia con el lector. En tanto, la metáfora refiere a una comparación abreviada que suprime en ella el nexo comparativo o lo sustituye por uno de otra clase. La ironía, por su parte, plantea el problema de la connotación asociativa en la medida en que, en un punto de una secuencia discursiva, un significante

\footnotetext{
${ }^{33}$ Julien Greimas define a la isotopía como "un conjunto de categorías semánticas redundantes que permiten la lectura uniforme de un discurso" (Greimas, 1970: 188). Toda secuencia isotópica distinguirá varios tipos de isotopía: semántica, fonética, prosódica, enunciativa, retórica, presuposicional, sintáctica, narrativa y claro está, estilística.
} 
recibe la carga de dos valores heterogéneos en cuanto a su estatuto, esto es: un valor literal, y un valor asociado.

La emergencia de esta dualidad surge bajo la presión que los contextos lingüísticos y extra-lingüísticos ejercen sobre el significante. Ironizar es una manera de burlarse de alguien o de algo diciendo lo contrario de lo que se quiere hacer entender y no decir lo contrario de lo que se piensa. En tanto, las reminiscencias culturales son connotaciones también intertextuales, pues el proceso de enriquecimiento connotativo puede resultar de un tratamiento anterior, no precisamente lingüístico, sino semiológico del concepto en cuestión.

Por último, en la relación referencial los objetos extra-lingüísticos constituyen por sí mismos valores connotativos. En este caso, la lengua recupera estos valores en su propio beneficio cuando convierte esos objetos que le preexisten en denotados de signos. Estas connotaciones, que a menudo se llaman simbólicas, y que se definen por la particular naturaleza de su soporte significante (el objeto extralingüístico denotado) se caracterizan porque el conjunto de la comunidad la comparte en su gran mayoría.

Por su parte, Ducrot reconoce a Bajtín como precursor de la perspectiva polifónica y propone una teoría que inspecciona la intervención múltiple de las voces en los enunciados. A partir de ello, en una enunciación pueden presentarse distintas subjetividades que se oponen o marcan identificaciones determinadas. El alcance analítico de la polifonía, entonces, permite analizar la instancia en la que el locutor coloca en escena distintos puntos de vista hacia los que mantiene posiciones diversas.

La mirada de Ducrot (principalmente cuando establece la relación con Gerard Genette) posibilita un acercamiento fructífero y acorde con el análisis discursivo d las letras de canciones. Como se dijo, este autor señala que el enunciado no corresponde únicamente a un sujeto, sino que permite la participación de muchas voces: "El decir es como una representación teatral, como una polifonía en la que hay una presentación de diferentes voces abstractas, de varios puntos de vista y cuya pluralidad no puede ser reducida a la unicidad del sujeto hablante" (Ducrot, 1986). De acuerdo con esto, se manifiestan tres entidades polifónicas vinculadas con el sujeto hablante:

\begin{tabular}{|l|l|}
\hline Entidades polifónicas & \multicolumn{1}{|c|}{ Definiciones } \\
\hline Sujeto Empírico (SE) & $\begin{array}{l}\text { Se entiende como el autor efectivo del discurso o el productor del } \\
\text { enunciado, que profiere las palabras o las escribe (en el caso de } \\
\text { esta tesis, la situación refiere a los compositores determinados de }\end{array}$ \\
\hline
\end{tabular}




\begin{tabular}{|l|l|}
\hline & $\begin{array}{l}\text { las líricas: Charly García, Gustavo Cerati, Federico Moura o } \\
\text { Celeste Carballo, entre otros). }\end{array}$ \\
\hline Locutor (L) & $\begin{array}{l}\text { Se considera como el ser del discurso, puesto que tiene la } \\
\text { responsabilidad del enunciado y de la enunciación misma. En la } \\
\text { mayoría de los casos, está inscrito en el sentido del enunciado y } \\
\text { está designado en las marcas de primera persona: "yo", "mín" y } \\
\text { "me". La "voz" de este locutor tiene una dimensión verbal y por } \\
\text { ello se le atribuyen palabras. }\end{array}$ \\
\hline $\begin{array}{l}\text { Enunciadores - Puntos } \\
\text { de Vista (E) }\end{array}$ & $\begin{array}{l}\text { Corresponde a los puntos de vista o las otras voces que aparecen e } \\
\text { intervienen en el discurso }\end{array}$ \\
\hline
\end{tabular}

En relación con el anterior cuadro, es necesario remarcar que la figura del locutor resultó fundamental en el estudio de las líricas, puesto que a través de su situación discursiva se pudieron evidenciar los enfoques ideológicos articulados en el discurso. Igualmente, la aparición de las voces correspondientes a los enunciadores conllevó, inevitablemente, a la aparición de puntos de vista que, en distintas ocasiones, plantearon posicionamientos enlazados una discursividad poética, realista o ironista sobre la construcción de lo real en un contexto de transición democrática.

Siguiendo esta línea, las letras de rock argentino constituidas como corpus presentan una experiencia inter-textual vinculada con relatos previos de la propia historia del rock argentino e, indudablemente, con los desarrollos culturales y políticos del país durante el período 1982-1989. En este aspecto, el análisis de la polifonía advirtió un modo de integración o juego semántico y tematizante de la libertad que sitúa su definición a lo largo de este trabajo como espacio de negociación o zona de tensión en un ámbito de conmoción pos-dictatorial. 


\section{Capítulo V}

\section{Transición, retirada militar y construcción discursiva de la libertad}

\subsection{Rock/pop argentino: el diálogo con el pasado reciente}

El diálogo persistente entre las nociones de libertad, el concepto de transición democrática y la asimilación de una reconstrucción democrática plantearon distintas vertientes en el universo de la cultura rock argentina. En este sentido, y como se mencionó previamente, la definición de la transición democrática contuvo una concepción de construcción en una sociedad frágil, configurada como víctima de la violencia política de la década del 70.

Por tanto, los indicios de recuperación democrática que se abrieron a partir de la finalización de la guerra de Malvinas encontraron preocupaciones acuciantes sobre el lugar de las Fuerzas Armadas en un proceso de estado de derechos. La sociedad se encontraba reconociendo aún su propia tragedia y las amargas experiencias provocadas por el terrorismo de Estado.

Tras la derrota de Malvinas y la posterior caída del dictador Galtieri, las islas estaban en manos de los ingleses nuevamente, los desaparecidos (como figura y tensión) se instituían como temática en los medios de comunicación que anteriormente lo habían ocultado, la economía se encontraba en un momento crítico (ya no se hablaba de "plata dulce" ni de dólar bajo) y la deuda externa comenzaba a ser moneda corriente en las discusiones.

En términos de la investigadora Marina Franco, la condena de la represión, en estos tiempos, también puede entenderse de un modo relativo porque no se realizó en términos directos. Los años que transitaron entre los años 1982 y 1984, previos a la escena abierta por la construcción del Nunca Más ${ }^{34}$ y la realización del juicio a las Juntas $^{35}$, condensaron una discusión menos amplia en relación con la violación a los derechos humanos y el terrorismo de Estado (2015: 65).

\footnotetext{
${ }^{34}$ Expresión utilizada para repudiar el terrorismo de Estado perpetrado por la última dictadura cívicomilitar. Nunca Más también es el título del informe de la Comisión Nacional sobre la Desaparición de Personas (CONADEP), que se publicó en 1984 y que aún hoy tiene sucesivas reediciones en el país.

${ }^{35}$ Se conoce con este término al proceso judicial llevado a cabo por la justicia civil en 1985 contra las tres primeras juntas militares de la dictadura a raíz de las masivas violaciones de derechos humanos realizados durante el régimen.
} 
La situación en la transición democrática se encontraba marcada entonces, por la revalorización de la democracia como espacio para autonomizar la política, brindar cobertura ciudadana y activar un refugio directo ante el autoritarismo presente en el pasado. En un mismo sentido, se evidenciaba un deterioro en las capacidades estatales, como consecuencia de la activa presencia de los mercados y la intervención de actores internacionales, vinculados con lo económico que comenzaron a acechar al país (Fondo Monetario Internacional -FMI- y Banco Mundial).

La libertad por añadidura, se vinculaba con una disposición de revalorización democrática que se destacaba en los medios de comunicación, en las discusiones políticas y académicas, y en las conversaciones cotidianas: "De una forma u otra, la mayor parte de la sociedad estaba dispuesta a otorgar un nuevo valor a la democracia. Un nuevo consenso se instalaba en lugar de los confusos modelos que habían campeado sobre la ciudadanía durante décadas" (López, 1994: 13).

El cambio que se vislumbraba tras el regreso de la democracia había generado renovadas discusiones en materia política. En este sentido, los jóvenes, que habían mantenido en pie su espíritu generacional en los recitales de rock y las manifestaciones artísticas, por citar dos ejemplos, empezaban a ser interpelados por los diálogos generados por la transición:

Mientras Madres de Plaza de Mayo y organizaciones de derechos humanos lanzaban la consigna "Juicio y castigo a los culpables" y la Multipartidaria organizaba una marcha masiva en Plaza de Mayo para el mes de diciembre (de 1982), la condena moral al Proceso se extendió por casi toda la sociedad (...) En los recitales se coreaba contra los militares, cada vez con más energía, y a veces entre los cánticos se sumaba algún extemporáneo “¡Viva Perón!”, siempre festejado con risas (Pujol, 2005: 223-224).

La intensidad que traía aparejada la reconstrucción democrática se aplicó en relación con las responsabilidades de la memoria reciente y las demandas de justicia que se enlazaban con las tareas de la reconfiguración del estado y el nuevo pacto de la sociedad después de la guerra de Malvinas. A partir de ello, se evidenció una puesta en común de hábitos, formas, valores y nociones democráticas que interpelaban directamente a los jóvenes identificados con la cultura rock. 


\subsubsection{Rock y construcción del pasado reciente}

Las líricas seleccionadas para este capítulo articulan discursos que se encuentran atravesados, de un modo lateral, por condiciones de producción que reflexionaban lo sucedido en la década del 70 de una manera polarizada, sin inmiscuirse directamente en las responsabilidades políticas y criminales. La temática merodea una construcción de libertad distanciada de los epítetos grandilocuentes y universalistas de liberación o, en cierto sentido, de orientación revolucionaria. La estrategia discursiva, en consecuencia, contribuye a una memoria cercana, vinculada con el contexto político legitimado por el oficialismo y, sobre todo, por la figura y la propuesta teórica del presidente radical Raúl Alfonsín.

A modo general, las líricas articulan las secuelas de la dictadura y, por consiguiente, efectúan una crítica a la automatización que imponía el sistema y el consumismo postdictatorial, y también una afrenta contra la intolerancia, la explotación y el militarismo. En el mismo sentido, las letras continuaban refiriendo "a la búsqueda del amor, de la paz, de la naturaleza y de la libertad..."36 (Beltrán, 1989: 70).

Las letras proponen una disputa con los discursos que respaldaban compromisos políticos o de protesta de los años previos. Se ratifican así pretendidas nociones despolitizadas o desamparadas políticamente a conciencia, que convocaban cambios relacionales de politización durante la reconstrucción democrática y el propio desarrollo cultural del rock argentino.

En función de ello, interesa pensar en el carácter fluido y elusivo propio de los acontecimientos históricos que se articulan en los discursos de las líricas, puesto que los relatos sobre la dictadura y las memorias sociales se acrecientan y sobre-determinan en relación con un pasado de exterminio y desaparición (Kaufman, 2014: 1). De esta manera, las líricas habilitan indagaciones que atraviesan dimensiones sensibles y vigentes en torno al conflicto, las diferencias y las causas que ocasionaron violencias y sufrimientos en otras épocas y que la democracia debía contener.

La libertad, desde esta óptica, se aborda en pos de un plazo de negociación que se distingue en relación con lo que se pretende ser en la vida. Se la piensa entonces, como un capital en disputa que propone saberes, luchas y discusiones, y expone distintas formas de concepción. Las líricas hablan de liberación en relación con la última

\footnotetext{
${ }^{36}$ El empleo de los puntos suspensivos están inscriptos en el texto original.
} 
dictadura cívico militar, repelen los mandatos autoritarios del propio rock argentino y del mismo sistema capitalista o, más bien, de las convenciones sociales; y, del mismo modo, admiten las experiencias como fuente de inspiración en un contexto de reconstrucción democrática.

Las letras seleccionadas como corpus remiten a los discursos y a los debates vinculados con la transición democrática y precisamente, el pasado dictatorial. De este modo, se aprecia un discurso de rechazo hacia el autoritarismo y una aceptación temática de la libertad desde una clave de apertura democrática. Se plantean así discusiones en torno a una memoria social que advierte un campo de luchas y de disputas simbólicas y/o representativas referidas a un pasado que ponía en cuestión a los años previos de la dictadura y a su proceso en sí. La memoria, como instancia recuperada en la tematización de la libertad, se advierte interpelando tanto al pasado como al presente, atravesando un horizonte de expectativas futuras y proyectuales.

Las perspectivas que se articulan asimismo, resultan trascendentales porque comprenden los cuadros dialógicos y discursivos que se activan y retroalimentan con el espacio social y contextual de época. La construcción discursiva de la libertad que se efectúa en las líricas subraya situaciones complejas y diversas en torno al problema de la dictadura, la condena del terrorismo de estado y la consolidación de un marco democrático. A partir de ello, la estrategia enunciativa articula instancias heterogéneas y se coloca como marco de reflexión y discusión en espacios sociales disímiles. De esta manera, la significación del período seleccionado advierte un contexto que desde las líricas, propone distintos estados, intereses y problemáticas.

\subsection{Análisis de las líricas}

Las líricas que se presentan a continuación, detallan una situación de expectativa en relación a los aspectos democráticos que se abren a partir del declive de la última dictadura militar. Se analizan así ocho líricas que articulan una discursividad temática en torno a la libertad y sus continuidades en un proceso de ruptura y de salida dictatorial:

1) "Inconsciente colectivo" de Charly García (1982) se inmiscuye en una temática de libertad que atraviesa las prácticas de los hombres y las mujeres, exhibiendo una noción heroica y esperanzadora. 
2) "Ahora estoy en libertad" de Celeste Carballo (1982) se centraliza en una mirada más personal que construye a la libertad en relación con las ataduras y las prohibiciones vividas en tiempos dictatoriales.

3) "Buenos cimientos" de La Torre (1982) presenta una construcción de libertad desde el instinto de preservación por parte de los jóvenes.

4) "Su, me robaste todo" de Zas (1983) destaca una instancia metafórica que intenta realizar un racconto de lo sucedido durante la dictadura, observando sus resultados en la cotidianeidad

5) "Ellos nos han separado" de Virus (1983) hace hincapié directamente en la consecuencia más horrorosa de la dictadura: los desaparecidos. A partir de ello, construye un discurso dispuesto a revalorizar la libertad como herramienta para construir un futuro.

6) "No me dejan salir" de Charly García (1983) propone un juego entre las sensaciones de hartazgo y, a la vez, de esperanzas que trae aparejada la postulación de una libertad que se ansía.

7) "Viaje a la libertad" de La Torre (1983) ofrece una perspectiva también esperanzadora de la libertad, anunciando lo que se debe evitar como sociedad y como sector juvenil.

8) “Dónde estás guardada?” de María Rosa Yorio (1984) por último, se presenta como la única lírica de este capítulo publicada en un contexto democrático y que sin embargo, resguarda los temores en la conformación de la libertad aún en un estado de derecho.

\section{2.1. Es necesario cantar de nuevo}

"Inconsciente colectivo"

Charly García (1982)

Charly García es uno de los artistas de rock argentino más influyentes y reconocidos de Latinoamérica. Fundó e integró las bandas Sui Géneris, La Máquina de Hacer Pájaros y Seru Giran, y asimismo, desarrolló un trabajo solista exitoso a lo largo de su historia. Particularmente, este análisis toma como referencia a una de las líricas editadas en su aclamado primer disco solista, denominado Yendo de la cama al living y editado en agosto de 1982. 
La edición de este disco se realizó en un año clave para la historia argentina porque integró tanto las incipientes revueltas sociales desatadas en los centros urbanos del país, el comienzo efervescente de la Guerra de Malvinas y el inevitable ocaso de la dictadura militar tras la derrota en el atlántico sur. Del mismo modo, mediante el título del disco, García supo sintetizar una metáfora muy ilustrativa del momento: yendo de la cama al living denotaba una situación de encierro y de movimientos mínimos en un lugar estrecho.

El álbum se lanzó al mercado en conjunto con la banda sonora de "Pubis Angelical", instrumental compuesto especialmente para la película de Raúl de la Torre, basada en la novela del escritor Manuel Puig. Como señala la investigadora Mara Favoretto, el disco presentaba temas profundos y sentimentales como "Yo no quiero volverme tan loco", "Canción de dos por tres" o "Inconsciente colectivo", pero también alusiones irónicas y burlescas sobre la realidad dictatorial en tiempos del conflicto de Malvinas: "No bombardeen Buenos Aires", "Superhéroes" (2013: 49).

Particularmente, "Inconsciente colectivo" es la última lírica del disco y, si bien fue compuesta por Charly García en 1981, presenta un discurso distintivo que difiere de su antecedente inédito ${ }^{37}$.

De acuerdo con el investigador Sergio Pujol, la canción cobró importancia a partir de la depresión que la guerra de Malvinas había provocado en la sociedad argentina meses antes. El inconsciente colectivo de aquel momento simbolizaba una mezcla de desazón y bronca; de dolor y de cierta esperanza ante la inminencia de la retirada de la dictadura (2005: 230). Por tanto, la canción "comunicaba la certeza de que, a pesar de todo, podía haber un futuro (...) y una comunión que trasvasara los códigos del rock, que pudiera incluir a una audiencia un poco más amplia” (2005: 231).

La letra de "Inconsciente colectivo" plantea una idea de libertad persistente y constante en la vida de los seres humanos y refiere a la tensión entre lo nuevo y floreciente, y el escenario negativo, potencialmente contextual que remarca un sometimiento y una consumición por parte del sistema:

"Nace una flor, todos los días sale el sol, de vez en cuando escuchas aquella voz. Cómo de pan,

\footnotetext{
${ }^{37}$ Sólo fue interpretada por Seru Girán antes de su separación, a principios de 1982.
} 
gustosa de cantar, en los aleros de mi mente con

\section{las chicharras".}

En este enunciado, se considera la presencia verbos fundamentales que dominan la regularidad de la lírica y forjan un corolario de carácter positivo empleados por el hablante: nace (nacer), sale (salir), (escuchas) escuchar y cantar. Igualmente, se destaca la satisfacción de ofrecer el canto (gustosa de cantar) y se resalta el deleite y el placer del acto. En este sentido, el concepto perceptible y abstracto de la libertad, como base y fundamento para la realización del ser humano, forma parte de un inconsciente colectivo, vinculado a una razón particular e individual que se contrapone a las condiciones de producción que lo obligan a desistir.

La construcción de la libertad se vincula con una razón que se esparce internamente y admite un conocimiento libertario que permite hallar un estado característico en instancias positivas y adversas. En este aspecto, el enunciado en los aleros de la mente con las chicharras resulta surrealista y podría vincularse polifónicamente con la concepción de "La Cigarra" de María Elena Walsh porque instaura una imagen de espera que se abre ante la inminencia y permite admitir un hablante con voluntad comunicativa y sensibilidad pertinente.

En la siguiente estrofa, se aprecia la presencia de un vehículo de energía que, a partir de una construcción enunciativamente negativa, produce inconvenientes en el desarrollo de la vida:

"Pero a la vez existe un transformador que te consume lo mejor que tenés. Te tira atrás, te pide más y más, y llega un punto en que no querés”.

El consumo, por cierto, aplica una instancia de destrucción y extinción que mantiene un potencial: el hecho de consumirse obliga a retroceder e impide avanzar (consume lo mejor que tenés, te tira para atrás), demanda e insiste (te pide más y más), somete o domina pese a la posible contribución (llega un punto en que no querés) y transforma o convierte (transformador). Así, las cualidades de la segunda persona se articulan y remarcan una generalidad que también incluye al locutor (te tira, te pide, no querés).

Sobre este punto, cabe señalar lo enunciado por Pujol, puesto que el inicio de la lírica propone dos mundos distintivos y opuestos: el de la libertad proclamada por la cultura 
rock desde sus inicios y el de un escenario contextual opresivo en el que, de una manera traumática, el rock argentino parecía haber descubierto una fortaleza política en tensión: "El gran acierto de esta canción icónica (...) radica en esa dialéctica entre la utopía y realidad; entre la libertad que se anida en el corazón y ese 'transformador' que "consume lo mejor que tenés"' (2010: 327).

En el siguiente enunciado, particularmente reconocido por los seguidores de rock argentino, se advierte la presencia de un hablante activo que enuncia su discurso desde una postura de recomendación y de instancias reflexivas:

"Mama la libertad, siempre la llevarás dentro del

corazón. Te pueden corromper, te puedes olvidar, pero ella siempre está”.

La construcción de la libertad, en esta instancia, se articula como un espacio que debe aprehenderse de un modo primigenio y original. Por tanto, el verbo mamar aplica una idea de infancia y de concepción vital para la vida. La libertad se aprecia como un alimento para la vida que mantiene su vigencia temporal (siempre), se encuentra encarnizada al interior de los hombres y las mujeres en general, y no solo en la constitución existencial de los seguidores de rock o de los alocutarios postulados por la lírica: mama la libertad, siempre la llevarás dentro del corazón.

En esta última escena, la lírica reitera la idea de un colectivo aparte (ellos) y la presencia de una segunda persona (tú) que admite el consentimiento del locutor en la enunciación. El colectivo ellos, que en la anterior estrofa se vinculaba con las instancias negativas del consumo y las nociones que inhabilitaban las experiencias activas humanas, se advierte desde un lugar perverso que propone la idea de corromper y entregar la libertad, en pos del beneficio personal.

A pesar de ello, la responsabilidad negativa no se relaciona únicamente con el colectivo ellos, sino también destaca una crítica hacia el alocutario (tú) porque remarca una posible ausencia de compromiso y de defensa en desmedro de la preservación de la libertad y la memoria que la activa: te puedes olvidar.

De la misma manera, se distingue también el empleo de antagonismos que no solamente se vinculan con las nociones opuestas de nacer/consumir y/o corromperolvidar/persistir-perseverar, sino se diferencian de los marcos temporales del pasado y el presente de la enunciación: 
“Ayer soñé con los hambrientos, los locos, los que se fueron, los que están en prisión. Hoy desperté cantando esta canción, que ya fue escrita hace tiempo atrás. Es necesario cantar de nuevo, una vez más”.

En primer lugar, el empleo del deíctico temporal (ayer) se enlaza con los espacios de sueño o ensoñación (ayer soñé) que remarcan un pasado turbulento y tormentoso de necesidad ("los hambrientos"), los exilios forzados o auto-impuestos (los que se fueron), y los detenidos en dictadura que aún se encontraban en la sombra, sufriendo el terrible pasado (los que están en prisión).

En segundo término, la actualidad del deíctico temporal también se relaciona con el despertar y la ausencia de letargo (hoy desperté), la actividad del canto que se había enunciado en el principio de la lírica (cantando esta canción) y la presencia del pasado (ya fue escrita hace tiempo atrás"), pero con intenciones de reconfiguración desde el presente de la enunciación (es necesario cantar de nuevo una vez más). Este enunciado, en consonancia, también remarca una modalidad imperativa que plantea una necesidad de actuación que no se ocupa de banalizar el canto, sino de plantearlo de un modo certero e infalible en virtud del contexto de la retirada militar: es necesario cantar de nuevo una vez más.

Al respecto, la periodista Gloria Guerrero destaca la importancia de este enunciado en el recital que Charly García había brindado en el estadio de Ferrocarril Oeste en diciembre de 1982:

"Y ahora es la Negra Sosa y la muchachada muta de nuevo. 'Se va a acabar la dictadura, sí que se va a acabar': 'No queremos milicos ni represión, grita García. 'Ayer soñé con los hambrientos, los locos, los que se fueron, los que están en prisión', canta Mercedes, y se prenden miles de pequeñas llamitas en las tribunas. Y se levantan los dedos en V, flameando sobre las cabezas" (1994: 87).

En relación con ello, se coincide con Pujol al señalar la importancia del concepto inconsciente colectivo en esta última estrofa porque el discurso no solo incluye a los seguidores de rock, sino también a todos aquellos que habían buscado la libertad en 
distintos espacios: “Ahí estábamos todos, esa canción cantaba con nosotros y por nosotros. Ayer, hoy y mañana, ya que había sido "escrita hace tiempo atrás"” (Pujol, 2005: 167).

\subsubsection{Libertad para sentir y para amar}

"Ahora estoy en libertad"

Celeste Carballo (1982)

Celeste Carballo debutó con su disco Me vuelvo cada día más loca en agosto de 1982, luego de varios años de presencia en el underground de la cultura rock argentina. Por esto mismo, se confirmó como una de las artistas femeninas más significativas del ambiente, ya que el material reunía composiciones propias que se convertirían posteriormente en clásicos del rock argentino.

En este sentido, el álbum funcionó como una carta perfecta de presentación en el universo de la cultura rock argentina porque contaba con las participaciones célebres de Norberto "Pappo" Napolitano, Nito Mestre, David Lebón y Oscar Moro, entre otros. De hecho, el disco produjo distintos éxitos que aún resuenan en la historiografía del rock argentino: "Me vuelvo cada día más loca”, "Una Canción Diferente”, “Querido Coronel Pringles", "Es la vida que me alcanza" y "Ahora estoy en libertad".

Me vuelvo cada día más loca es una obra que unificaba distintos puntos insoslayables en la carrera de Celeste Carballo porque, por un lado, daba cuenta de su trayecto artístico y por otro destacaba una relación amorosa turbulenta: "No fue un éxito de la noche a la mañana. Tenía canciones que venía cantando hacía dos años y otras de ese momento, como "Me vuelvo cada día más loca", que hice cuando estalló la Guerra de Malvinas y se refería a no aceptar como normal la violencia del Estado" (Plaza, 2015).

Precisamente, la lírica "Ahora estoy en libertad" presenta un discurso celebratorio, en la que el hablante resalta, desde la primera persona su relación con la libertad y las conducciones escapatorias en un contexto que se abre hacia nuevas posibilidades. Se advierte así la presencia de un locutor que se muestra expectante y que confía en las posibilidades de desarrollo propuestas por las nuevas instancias de libertad.

En este aspecto, la libertad, como condición y postulación, se aplica en relación con el sentimiento, el amor, la pasión y la emoción. Se revela una creencia que se enuncia desde el presente del indicativo (creo) y que da por cierto una situación que admite ambigüedades, desde un sentido literal. Si bien la expresión creo permite destacar un 
entendimiento que no alcanza o que no está comprobado o demostrado, en esta instancia se potencia una posibilidad de confirmación, modalizada desde la aseveración, en detrimento de nociones dubitativas o indecisas:

\section{"Creo que estoy en libertad para sentir y para \\ amar. Creo que tengo lo que pedí. No me lo \\ dieron, yo lo consegui'”.}

De acuerdo a este último enunciado, el hablante declara una intención de pedido que no parece dirigirse hacia una persona en particular o, por lo menos, no lo enuncia de un modo denotativo. No obstante ello, se subraya la autonomía de un logro determinado (una victoria, un alcance que se desea recalcar) porque no se destaca una ayuda ni un empuje particular, sino se acentúa el cumplimiento de un objetivo que se vincula con el efecto de encontrarse en libertad (estoy en libertad). La libertad entonces, no se aplica únicamente desde las pretensiones afectivas, sino también desde la autonomía personal y la resolución individual: Y aunque ahora siento un poco de frio, creo que el tiempo me traerá el abrigo.

Sin embargo, la felicidad de la libertad, como nombre y concepto, no ofrece suspensiones y/o relaciones separatistas. Por el contrario, es cotejada a partir de un adverbio de tiempo o de una deixis temporal (ahora) que refiere a un momento presente, relacionado con un escaso o reducido tenor impávido (frío). Asimismo, el anterior enunciado destacado puede interpretarse como un escenario imperturbable que acerca sensaciones de temor en términos dictatoriales $\mathrm{y}$, en simultáneo, con ciertas nociones valoradas de un modo negativo, residuales de opresión u absolutismo.

El tiempo, en este caso, podría comprenderse como un desplazamiento positivo y un horizonte futuro que abriga y habilita el acompañamiento o el calor que indicaría una relación con un estado de cuidado o de resguardo. A pesar de ello, la creencia que se destaca parece más vinculada a lo dubitativo, que a la certeza (creo que el tiempo me traerá el abrigo).

En virtud de la celebración inicial, la lírica avanza y admite una actualización que pretende enfatizar el momento de libertad y, sobre todo, la instancia de goce que tiene el hablante: pero ahora estoy en libertad, ahora estoy en libertad. El deíctico temporal ahora es trascendental porque marca un hecho de momento dominante, relacionado con un rol activo: 
"Me gustaría meterte en mi alma. Me gustaría estar tan enamorada, que no me queden las ganas ni el tiempo. Deshacerte de abrazos, de dulzura y

$$
\text { deseo”. }
$$

El actual enunciado cobra importancia porque el locutor postula un alocutario directo que no se había advertido anteriormente. Este nuevo escenario, sin embargo, remarca la instancia de pasión y enamoramiento, y rescata las nociones de deseo y aspiración. La implicancia enunciativa, por tanto, se relaciona con una privacidad de compartimiento íntimo y un anhelo que profundiza la dedicación del amor (tan) para referirse a algo que es exagerado, y que da como resultado lo que se expresa.

La perspectiva de expectación que subraya el hablante presenta aspectos positivos que enmarcan un campo semántico de romanticismo y que remite a los abrazos, la dulzura, el deseo, el enamoramiento, el alma y las ganas de amar. El acto modalizador, a partir de ello, destaca ansiedades e incertidumbres y expresiones de deseo:

\section{"Pero no quiero nunca más las cadenas, porque ya vi, ya vi, eso es una condena. Por eso ahora quiero estar en libertad, quiero estar en libertad".}

Nuevamente, la conjunción adversativa pero, permite contraponer un concepto diverso que amplía aún más los enunciados iniciales y se relaciona de un modo directo con el escenario dictatorial en el que se produjo la lírica. Se subraya así un rechazo hacia las ataduras y, más aún, a los modos de obstrucción de la libertad. Se resaltan también las intenciones de concluir una etapa de encadenamientos y represiones que el locutor advirtió en un pasado cercano, y que a partir de sus consideraciones y observaciones, no desea vivenciarlos nuevamente.

Del mismo modo, el concepto nunca y la palabra ya se enlazan con las virtudes adverbiales-deícticas temporales que engloban la conceptualización que piden la oclusión de situaciones negativas en un tiempo presente, haciendo relación a un pasado de avasallamiento, relacionado, nuevamente, con la dictadura.

El hablante reitera la modalización aseverativa que expresa una relación interpersonal a partir de la cual el yo que enuncia se compromete con el vos/tú u oyente/alocutario en 
cuanto a que su enunciado es verdadero. La ambición, el deseo y el requerimiento, en tanto, se destacan a partir del rechazo hacia las cadenas y el alcance de libertad: " $E l$ miedo nos quita de a poco la vida. La calle está dura, nena ${ }^{38}$, nena, hay pocas salidas". En este enunciado, por cierto, se recalca la presencia de una voz, de un enunciador o de un punto de vista, en términos de Ducrot, que abre una instancia distintiva desde la pluralidad y que se aleja de la primera persona del singular con intenciones de incluir. Se propone así un sujeto del discurso que no se condice con la celebración propuesta desde los inicios de la lírica.

El miedo, en este caso, tiene una consideración negativa que separa y afecta la vida desde una perturbación angustiosa del ánimo y por un riesgo o daño que se aprecia real. Por tanto, la calle se vincula con una escena urbana sin concesiones, difícil de tolerar, que resulta violenta, cruel e insensible. El miedo resulta importante para ser combatido, para estar en libertad (eso parece exponerse en los inicios), pero este enunciado introduce la voz de un enunciador coloquial, de instancia social y popular que puede indicar que la calle está dura y que hay pocas salidas. En este último lexema, el modalizador típico de este enunciado imperativo se vincula con la construcción auxiliar del haber porque indica la instauración de un evento tajante y notablemente perjudicial (hay pocas salidas).

\subsubsection{La vida es nuestra}

"Buenos cimientos"

La Torre (1982)

La Torre fue una banda de estilo hard-rock/pop que se formó en 1981 y que tuvo una gran repercusión durante la década del $80^{39}$. El grupo proponía, desde sus inicios, un estilo particular desde lo sonoro (resonancias y extravagancias estéticas vinculadas con

\footnotetext{
${ }^{38}$ Hasta principios de la década del 80, la mayoría de las canciones del rock argentino estaban dirigidas hacia una hipotética mujer. De ahí provenían los apelativos coloquiales denominados nena, loca, querida $\mathrm{y}$, obviamente, mujer.

${ }^{39}$ La banda se disolvió a principios de 1989, al comenzar la carrera solista de Patricia Sosa, que se volcó más hacia la música melódica y romántica.
} 
el hair metal estadounidense ${ }^{40}$ ) y desde la imagen porque que tenía como líder y vocalista a una mujer: Patricia Sosa. Esto es de destacar porque hasta el momento las voces femeninas sólo habían integrado proyectos solistas (María Rosa Yorio, Gabriela y Celeste Carballo, por ejemplo), pero no había recuerdos de músicos femeninos al frente de una banda de rock.

A partir de la presentación de la banda en el festival BA Rock-1982, el ascenso de La Torre fue instantáneo y permitió un alcance de público femenino que no solamente vivaba a los músicos hombres, sino se sentía identificada con los mensajes postulados desde las líricas de la banda. Al respecto, Patricia Sosa resume en pocas palabras la identidad que tenía la banda en aquella época de posguerra: "Nosotros siempre fuimos muy duros para los blandos y blandos para los duros, estábamos en el medio. Lo nuestro era rocanrol de vez en cuando contestatario y otras veces divertido, pero con una base poderosa" (Guerrero, 1994: 109).

"Buenos cimientos" es la canción que le da inicio al disco debut de La Torre, titulado de un modo homónimo y publicado en septiembre de 1982. La lírica construye un lugar de obstinación, desde un lugar que enaltece y defiende la libertad. Ante esto, se constituye una marcada grieta que separa pronombres relevantes en la construcción del discurso y que suele trabajarse estratégicamente en distintos enunciados del rock argentino: en primer lugar, se advierte la presencia de un ellos colectivo que abruma desde su pretendida sabiduría y sus nociones de vida; en segunda instancia, se admite la presencia de un nosotros que incluye y que podría colectivizar tanto a las identidades juveniles del rock como a las otras comunidades de jóvenes que proponían prácticas tenaces e instancias libertarias en contexto dictatorial: para bien o para mal siempre saben la respuesta. No te dejan el consuelo de decir: "la vida es nuestra".

En este sentido, el colectivo ellos es criticado porque se muestran del lado del conocimiento y arbitran sobre un campo verbal de mandamiento y dominación: saben (saber), dicen (decir) y no dejan (dejar). El empleo del ellos parece vincularse con la idea de conocimiento o de dominio de las confidencias particulares que, por ende, asiente la ignorancia de los otros colectivos y les impide el alivio y las formas de nombrar o de hablar.

\footnotetext{
${ }^{40}$ Término despectivo que refiere a los grupos que ostentaban peinados abultados, y remite a bandas que utilizaban maquillaje y ropa recargada con cierta intención de ambigüedad sexual durante la década del 80.
} 
En consecuencia, el colectivo ellos no admite el consuelo o la autonomía del combinado nosotros puesto que estos últimos, a partir del discurso de la lírica, evidencian un bloqueo, un impedimento de habla y de independencia que obstruye la propia libertad. Esto permite comprender que tanto el beneficio útil o conveniente (para bien) como el daño material o moral (para mal) se encuentran en un mismo nivel de gravitación porque no permiten modificar las supuestas sabidurías y los presuntos conocimientos del colectivo ellos.

De hecho, el deíctico temporal siempre refuerza la idea de constante búsqueda de dominación y de respuesta que plantean los que saben (quienes hasta esta instancia, no se revelan). Este marco enunciativo es trabajado a partir de un hablante plural que, desde el inicio de la lírica, confecciona una estrategia grupal de complicidad e interpela directamente a los interlocutores: no te dejan. La alusión incluye a ambos, tanto al yo de la lírica, como al vos, al ustedes y al nosotros que ofician de interlocutores.

Del mismo modo, vale señalar que el enunciado la vida es nuestra destaca la presencia de una voz polifónica que irrumpe desde el enunciado referido de discurso directo y que se enlaza con una convicción que indica libertad y autonomía de decisión en la propia vida o en las propias vidas de los jóvenes y seguidores de rock argentino.

Por consiguiente, el enunciado (que también conmemora el estribillo de la lírica) resulta relevante por la recurrencia del plural que sobresale y se desprende de aquel enunciado que indicaba la potestad de la propia vida del colectivo nosotros: vamos a gritar nuestra libertad. No dejes mover todos tus cimientos.

Al respecto, se destaca la importancia de gritar, hacerse escuchar e impedir el movimiento o más bien la persuasión y la incitación que perjudique la convicción y la integridad moral de los sujetos o los jóvenes (los llamados cimientos). La libertad se manifiesta a partir de dos potencialidades directrices: en principio, se destaca la unión del colectivo nosotros (vamos) en pos de la defensa de la libertad y, en segundo término, se subraya un discurso que propone mantener las bases, las idiosincrasias y la autenticidad hacia un alocutario que se aprecia acomplejado y avasallado por el contexto (no dejes mover todos tus cimientos).

En este aspecto, el hablante expone un relato que se narra a partir de la primera persona, enunciando acontecimientos o hechos que tuvieron lugar en el pasado, es decir en un tiempo anterior al momento en el que se produce construcción enunciativa de la lírica: 


\section{formal que miraba a todo el mundo diciendo: \\ ‘todo esto está mal'”.}

Esto es válido porque la narración transita una puesta en acción cotidiana, que destaca la presencia de una tercera persona (denominada tipo) que denota un grado superlativo de formalidad y estructuración (un tipo muy formal) y que resalta opiniones amargas y apesadumbradas acerca del contexto: todo está mal. De hecho, este último enunciado distingue la apreciación de una voz o punto de vista que irrumpe y que analiza amargamente el escenario social a partir del adjetivo todo.

Muy por el contrario, en el siguiente enunciado el locutor utiliza el presente como tiempo eje, especialmente a partir de los usos del presente de definición, y aplica una perspectiva hacia el pasado porque correlaciona el presente con el pretérito perfecto: pero yo que leo la mente deletree en su interior como se sacaría el traje y cantaría un rock and roll.

Esta correlación se debe a que el pretérito perfecto sirve para enunciar hechos que ocurrieron en el pasado, pero cuyos efectos llegan hasta el presente a diferencia del pretérito simple que presenta los hechos sin dicha conexión con el presente. El hablante idealiza al tipo muy formal, realiza una lectura de la conciencia sentimental del sujeto denominado tipo y entiende que ese individuo contiene una libertad obstruida que no puede expresarse libremente y que podría ser más independiente: pero (el tipo) se sacaría el traje y cantaría un rock and roll. En consonancia, también se aprecia una modalización lógica, de orden condicional que admite una suposición certera y que, a partir del desplazamiento de los verbos deletrear, sacar, cantar, leer, construye un tercero que se relaciona con la devoción por la música rock (cantaría rock and roll):

\section{“Intentemos, por lo menos, no dejar caer a todos. Los que saben la respuesta ya no están entre nosotros”.}

El último enunciado subraya una pluralidad que agrupa al nosotros y modaliza una orden a partir del adverbio por lo menos. Así se advierte una recomendación, pero también una representación de la juventud rockera de la época (intentemos, por lo menos). Se renueva entonces, la idea de no claudicar (no dejar caer) y de sostener la libertad del colectivo que sufre avasallamientos y desprotecciones (todos). 
De esta manera, se instala nuevamente el enfrentamiento entre el nosotros y el ellos (los que saben la respuesta), pero se destaca además la modalidad de enunciación aseverativa que expresa una relación interpersonal a partir de la cual el hablante se compromete con el oyente en cuanto a que se enunciado es auténtico: lo que saben la respuesta ya no están entre nosotros. La sabiduría en las respuestas se vincula así con una idea de arbitrariedad e imposiciones en torno a la verdad, muy propia del discurso severo y autoritario de la dictadura. Ante esto, conviene preguntarse connotativamente si el enunciado ya no están entre nosotros, refiere al ocaso de la dictadura y avizora la llegada de la democracia.

\subsubsection{Hay un destino nuevo}

"Su, me robaste todo" Zas (1983)

Zas fue un grupo liderado por Miguel Mateos que editó su primer disco en 1982, un mes antes del comienzo de la guerra de Malvinas. Si bien la banda supo cambiar de integrantes tras el lanzamiento de cada placa, siempre tuvo como referente principal a Mateos, quien se erigió como el principal compositor y letrista hasta que la banda se disolvió y comenzó a llevar su nombre.

La lírica que se destaca en este apartado fue editada en 1983 e integra el emblemático segundo disco de la banda: Huevos. La temática del álbum se centra principalmente en la llegada de la democracia a la Argentina y la mayoría de las canciones contienen temáticas relacionadas a la esperanza, a las nuevas formas de vida y a la crítica del pasado reciente totalmente dominado por la dictadura cívico militar.

Huevos es un álbum que contiene distintos sencillos exitosos de la primera era de Zas, como por ejemplo, "Extra, Extra", "Un poco de satisfacción", "Un gato en la ciudad" o “(en la cocina) Huevos”. Particularmente, las líricas dan cuenta de las inquietudes y los temores de la juventud en tiempos finales de la dictadura militar. Si bien, se advierten ciertas enunciaciones esperanzadoras, también es posible destacar una marcada desorientación sobre el presente y el futuro de los jóvenes.

"Su, me dejaste todo", es la sexta canción del disco y es una lírica que sobresale por la presencia de la libertad que, como construcción discursiva, resalta una situación de recopilación sobre lo sucedido durante la dictadura. En dicha letra, predomina una primera persona del singular que postula, declama y reclama a una tercera persona del 
singular. Esta última, denominada $S u$, es referenciada desde una instancia negativa y se la vincula con un ejercicio indebido moral y ético. Siguiendo la figuración de este punto de vista, $S u$ quitó o tomó para sí (con violencia y quizás con fuerza) lo ajeno y lo que la primera persona defendía y apreciaba: $\mathrm{Su}$, me robaste todo. $\mathrm{Su}$, me convertiste en lodo. Este último enunciado expone una situación preocupante que vivencia el hablante, puesto que la denominada $S u$ le obstruyó el camino, lo estancó y lo convirtió en lodo. En este sentido, también es posible comprender que el locutor se encuentra paralizado, ofendido y, metafóricamente, mezclado con tierra y agua, especialmente la que resulta de las lluvias en el suelo (lodo). La referencia no es ajena a la Guerra de Malvinas y argumenta en relación al propio terreno de las islas del atlántico. Seguidamente, el hablante sostiene las circunstancias que lo empujaron a ese estancamiento:

"Y tuve que especular con dinero inmoral.

Su, siete años a tu antojo. Invertí y perdi, fuera de

$$
m i ' \text { '. }
$$

Este pasaje enunciativo se vincula con el propio quehacer de aquellos que trabajaron con una economía alternativa, vinculada al mercado negro durante la última dictadura militar 1976-1983 (siete años a tu antojo). Por esto mismo, el hablante fue robado, enfangado y obligado a entrometerse en mercados peligrosos de especulación y de dinero inmoral (alejado del rigor de las buenas costumbres y la propia decencia). El destinatario, por lo que se aprecia, también cosechaba y generaba finanzas propias a partir de deseos e inquietudes espurias, sin consultar, sin preguntar y manejándose de un modo despótico. No obstante, si bien el hablante subraya la derrota y la ausencia de opciones que lo ubica en una posición asimétrica, aún demuestra instancias de tozudez y revancha:

\footnotetext{
"Su, mi mente aún trabaja. Su, aunque no des ventaja. No me podrás quebrar, ni vender, ni comprar. Su, soy clase media baja”.
}

En este enunciado, se destaca que la mente no pudo ser robada pese a la disposición de un terreno de desequilibrio y desigualdad (no hay ventaja por parte del oponente). El yo de la lírica se postula inquebrantable pese a todo, destaca que tuvo que jugar con reglas 
amorales, pero que no ha sido sobornado ni dadivado, exponiéndose desde un lugar auténtico. Su argumento se sostiene a partir de la pertenencia a la clase media baja, exhibiendo un extrañamiento en relación a la venta o en la compra de pensamientos o pareceres. Por tanto, el hablante se construye como víctima de lo sucedido y se desplaza hacia una situación de positivismo vinculada con un proceso inquebrantable:

\section{"En tanto, mi canto se parte con el llanto del pibe \\ que vende Geniol. Espero y quiero que el mundo, el mundo entero sepa de mi dolor por Su".}

En este sentido, el conector (en tanto) promueve el desplazamiento y articula una forma de transitar el argumento, en pos de demostrar que existe una posición alternativa. La mente se encuentra activa, con disponibilidades mínimas, pero con una postura inmutable que se expone desde una sensibilidad tajante: el canto se rompe con el llanto. De esta manera, el pibe que vende Geniol parece remitir a una propaganda específica o también al joven que trabaja ambulantemente vendiendo pastillas para el dolor de cabeza, mientras él mismo, como sujeto de la calle, sufre la realidad (llora). A pesar de ello, el hablante se muestra expectante y a la guarda: no sólo espera algo de sí mismo, sino del propio mundo. En consecuencia, busca denunciar y resaltar que aún persiste y sobrevive en un contexto adverso (que el mundo sepa mi dolor), separándose del dicho popular retomado de la canción folclórica "Entra a mi pago sin golpear": que nadie sepa mi sufrir.

En esta instancia, el yo busca que se conozca su propio dolor como lugar para atraer la libertad y demostrar que existe una situación peligrosa. A continuación, la referencia a la tercera persona $(S u)$ se enlaza con una situación de retirada, en la que le hablante le habla a alguien que se encuentra a punto de caer de un cuadrilátero de boxeo o de un campo de juego:

"Su, vas a pedir la hora. Su, tu cama no enamora.

Me mandaste a pelear contra Neptuno en la mar.

Su, láser versus boleadoras. Lennon, León, un

solo corazón". 
El lugar de la tercera persona no parece confortable, ni propone un espacio de enamoramiento, sino quizás, de rencores y odios. El hablante se postula desde la denuncia y le recrimina una obligación de lucha imposible contra un Dios de la aguas en el mar (Neptuno), con una potencia absolutamente disminuida, diferenciada que le jugó en contra. Al respecto, la alusión a la guerra de Malvinas se hace posible por la aparición del mar, por el láser y la metáfora de las boleadoras de los soldados argentinos que ni contaban con armas disponibles para enfrentar a Gran Bretaña en dicho conflicto. En este aspecto, el hablante vincula a la figura libertaria del músico integrante de los Beatles, John Lennon, con la del León Inglés que impone fiereza y la comunión de un único linaje, desde la repetición irónica.

\section{"Hay mucho en juego, hay un destino nuevo. Y ollas para destapar. Hay ganas, hay onda que nadie más se esconda por miedo a andar con la verdad".}

Volviendo a ese presente que no se enuncia desde el conector en tanto, el hablante destaca que las posibilidades de juego implican características y posibilidades varias. Porque el destino se abre hacia un nuevo paradigma y postula un horizonte que se construye a partir de lo que se conocerá y que se encuentra en pleno hervor (ollas para destapar) y en rigor de la urgencia: Su, Mambrú, se va a pasar al club de los que aman la libertad. Tan solo libertad.

Como señalan De la Puente y Quintana, en la lírica se expone un final de batalla y de racconto sobre la dictadura que advierte instancias favorables y positivas: "Siempre que se utilice la verdad, la libertad y la 'onda' como armas fundamentales, hasta va a conseguir conversiones que parecen imposibles" (1996: 131). Por consiguiente, la figura bélica de la historia o la canción popular de Mambrú es utilizada de un modo contrario y se lo relaciona con un nuevo espacio $(c l u b)$ que ama y lucha por la libertad. Es decir, se expone la figura de la libertad cómo único antídoto para certificar una situación de esperanza y expectación en detrimento del pasado oscuro. 


\subsubsection{Para que exista mañana}

"Ellos nos han separado"

Virus (1983)

Virus se formó en 1981 y se presentó en la escena del rock local como una alternativa que se diferenciaba de las ideas solemnes o anquilosadas de la década del 70, admitiendo una conexión bailable y vibrante con el público. La banda, liderada por el fallecido y recordado Federico Moura, se identificaba con un romanticismo estético que se vinculaba con el placer y el hedonismo como plan para alcanzar la liberación espiritual de los cuerpos y las conciencias.

Del mismo modo, a partir de sus líricas irónicas y ambiguas, tematizaba la libertad, la sensualidad, la homosexualidad y las experiencias con drogas de un modo desprejuiciado. Es también un grupo que manifestaba intenciones de desprejuicio social y de apertura mental en un contexto democrático y de respeto hacia los derechos humanos.

Para ejemplificar, los primeros dos discos de Virus, Wadu Wadu (1981) y Recrudece (1982) fueron resistidos por cierto público rockero purista y también por bandas que planteaban más rudeza en el aspecto sonoro y/o lírico. No obstante, con estos lanzamientos, Virus se posicionó como una banda ajena a la hegemonía musical del rock argentino, puesto que proponía una incitación al baile y planteaba un universo discursivo irónico, de apariencia pasatista y frívola: "Era una época nebulosa para el país, todo era difícil y había mucha paranoia, y nosotros nos juntamos para trabajar, darle forma a una música, tirar para adelante" (Lernoud, 1984: 33).

El tercer álbum, titulado Agujero Interior (1983), es uno de los más rockeros y directos que tiene la banda, no solamente por su sonoridad más vinculada al estereotipo de rock (la portada reflejaba a los integrantes de la banda en tono oscuro y con campera negra), sino por su lirismo inmediato, sin medias tintas, con provocaciones llanas y mensajes certeros: "Agujero interior se acercaba mucho más a lo que era el sonido real del grupo. Porque si bien a veces las composiciones te condicionan a determinado sonido, el sonido real del grupo era más power. No digo heavy, pero..." (Ciccioli, 2010: 99) La canción "Ellos nos han separado" fue publicada en 1983 y está situada como la quinta pista del disco Agujero Interior. La aparición de este álbum resultó muy importante en la carrera de Virus porque les permitió un ascenso comercial y masivo a 
partir de la rotación de canciones populares como "Hay que salir del agujero interior", "En mi Garage”, "Carolina” o "El Probador".

En lo que concierne a "Ellos nos han separado", se aprecia un vínculo polifónico con la propia historia del grupo porque referencia directamente a Jorge Moura, militante del Ejército Revolucionario del Pueblo (ERP) y hermano desaparecido de Federico, Julio y Marcelo (cantante, guitarrista y tecladista de la banda, respectivamente). Este acontecimiento se considera importante porque, a partir de esta construcción discursiva, la lírica aborda la discusión sobre la figura de los desaparecidos en el último año de la dictadura.

Por esta razón, la lírica expone una tensión considerable con el contexto porque aborda la temática de la desaparición, que se contempla como una de las herencias más horrendas del régimen militar y como una confusión e incertidumbre constante en la apertura de la transición democrática. En función de ello, la búsqueda del desaparecido simboliza una indagación sobre la verdad y sostiene la necesidad de contar con un discurso que disputara el sentido de los hechos, vinculados con un "estado de guerra" y con las "luchas contra la subversión" (Salvi, 2015: 177). Ciertamente, la desaparición incluye un daño e implica tanto el secuestro de un cuerpo como la sustracción de un saber (Jelin, 1995: 119).

En este sentido, la estrategia discursiva que presenta el locutor se articula a partir de una voz dirigente que dedica sus palabras al hermano desaparecido. De hecho, predomina la primera persona del singular y también se advierte la presencia de una primera persona del plural que organiza el discurso en pos de un reclamo o una declamación:

\section{"Hermano, quiero apretarte la mano. Sabemos que ellos nos han separado (...) Tenés que estar en cualquier lugar que pronto vamos a encontrar".}

En este caso, se acentúa la presencia de un yo que expone un discurso afectivo en relación directa con un parentesco (hermano). Del mismo modo, se postula un nosotros que expone un conocimiento y un reconocimiento de horror y se expresa una tercera persona del plural (ellos) que responde directamente al terror dictatorial.

No obstante ello, la estrategia enunciativa que plantea la lírica también puede comprenderse como una expresión que reúne de un modo simbólico a todos los familiares que padecieron la dictadura y continúan sufriendo las desapariciones, sobre 
todo si se toma en consideración el nosotros inclusivo empleado (sabemos, ellos nos han separado). Frente a esto, el hablante se posiciona reflexivamente sobre esta situación en plena retirada de la dictadura militar, destacando la trágica función de la desaparición y el horror del régimen:

\section{"Parece ser un mal general que va a haber que solucionar (...) Tenés que estar en cualquier lugar que pronto vamos a encontrar".}

Las consecuencias del terrorismo de estado (sus metodologías, sus acciones, sus condiciones) son señaladas como un tormento extensivo o, al menos, ampliable (parece ser un mal general). Asimismo, se ubica una instancia de esperanza en la democracia, remarcada a partir de una señal de expectativa demandante en relación con la resolución de los acontecimientos traumáticos (va a haber que solucionar) y la esperanza del encuentro (pronto vamos a encontrar).

Si bien, el empleo del nosotros inclusivo permite que el hablante contenga a los otros en su discurso, hacia el final de la lírica, el yo se inscribe directamente en la enunciación con el objeto de subrayar sus deseos desde la primera persona del singular: lo quiero. Esto es lo que yo quiero.

En este sentido, el hablante también evidencia su preocupación por el futuro y la esperanza que comprende a partir de la nueva etapa del país. La libertad es postulada como una instancia de la vida que se mantiene latente, aún en los momentos penosos y trágicos del devenir de los sujetos:

\footnotetext{
"Mañana, para que exista mañana. Porque la noche tiene final, la vida vuelve siempre a cantar. Con su pedazo de libertad amigos míos, una vez más".
}

Se produce así una confluencia novedosa que señala un rescate de las narrativas y los legados que refieren a los desaparecidos durante la dictadura. Como señalan Blanco y Scaricaciottoli, la lírica pone en correlación al militante político y social con el rockero incluso en su variante pop- marcando una ligazón entre las instancias de modificación de la sociedad desde lo social y político (setentista) y los caminos empleados por la cultura rock: "el terreno artístico transitado por Federico Moura y sus hermanos, y que 
por el contrario implicaba una complementariedad necesaria que no puede perderse si se quiere la construcción de "una mañana mejor'” (2014: 57).

De la misma manera, el contexto dictatorial es referido como una noche que se cierra, que concluye, mientras que la democracia puede entenderse como un espacio de vida que renace como una canción, y que debe cantarse en conjunto y con frecuencia. Este aspecto, se vincula con un fragmento de la lírica "Inconsciente colectivo", en la que se refuerza la modalidad de enunciado, intimando así la reiteración (es necesario cantar de nuevo una vez más). Esta apertura predispone una zona de liberación en la que el hablante imagina en su discurso y refuerza a partir del empleo de verbos que profundizan el acontecimiento de la vida:

"Para poder cantar, bailar. Para poder amar, gozar. Para poder reír, llorar. Tengo que estar con vos de nuevo. Porque eso es lo que yo quiero".

En función de ello, los verbos empleados presentan cargas valorativas que permiten crear un escenario de perspectiva positiva y liberación cotidiana en pos de la mencionada reunión a futuro. El modo de destacar la liberación y la esperanza también se relaciona con el encuentro con la justicia y la forma de encontrar justicia para los desaparecidos y las víctimas del terrorismo de Estado.

\subsection{6. ¿Quién es el cazador?}

"Viaje a la libertad" La Torre (1983)

"Viaje a la libertad" fue editada en 1983 y se ubica como la tercera pista del poco conocido segundo disco de La Torre: Viaje a la libertad. Dicho álbum presentó una orientación musical mucho más pesada o hard-rock que se había anunciado mínimamente en la obra debut. Por esto mismo, tras su lanzamiento, la revista Pelo señalaba que desde el aspecto literario Viaje a la libertad abordaba una temática más contestataria y demandante que descubría "un amplio camino por delante" $(1983,20)$. La revista Canta-Rock, en tanto, sostenía que a partir del lanzamiento de dicho disco, la banda se encontraba en su pico máximo de expresión compositiva y se presentaba de un modo excepcional en sus actuaciones en vivo (1985: 63). 
Por tanto, en "Viaje a la libertad" se aprecia la figura de una primera persona que domina la enunciación y que postula la presencia de un colectivo autoritario que obstruye libertades, silencia, grita y busca enloquecer (ellos). El hablante, por consiguiente, siente que no obtiene respuestas en sus reclamos ni explicaciones sobre los actos de violencia que le condicionan su actuar en la sociedad: si me encierran porque grito y no me dicen por qué. Y me gritan porque pienso, me quieren enloquecer. Siguiendo esta línea, la construcción discursiva incluye un contrasentido que aborda un corte a la ignorancia y postula así una otredad responsable del estado de ignorancia e incoherencia del contexto: si censuran la ignorancia y no se puede estudiar. Promocionan aire libre, no se puede respirar.

En este sentido, el hablante generaliza la expresión y la inscribe como una verdad general: no se puede estudiar. De esta manera, cambia el trayecto de su argumento, no se inscribe desde el yo, sino que lo extiende. Lo mismo ocurre con el bloqueo de la respiración: no se puede respirar. El colectivo ellos miente y arma de un modo lúdico y estratégico su postura. El hablante entonces utiliza la modalidad de enunciación interrogativa para exponer sus consideraciones sobre ese contexto grosero y perjudicial:

\section{"¿Quién me responde cuando pido que me expliquen el porqué de tanta violencia? ¿Quién es verdugo? ¿Quién es el cazador? ¿Quién responde cuando pido que me expliquen y no entiendo?".}

Estos interrogantes, por cierto, tienen una intencionalidad retórica que si bien no encuentran la respuesta en su contenido, no buscan una refutación, sino presentan una situación tácita: la dictadura es la respuesta. No obstante ello, esta ambigüedad o la disposición de interrogantes retóricos permite apreciar que el hablante no desea revelar la causa de todos estos arrebatos. En este último caso, es posible agregar que quizás necesita exponer un notable desconocimiento de la violencia y una confusión que puede postularlo como un sujeto sin demasiados conocimientos.

Necesita preguntarse quién es poseedor de la crueldad, tormento o el castigo (verdugo), y de la misma manera, cuestiona la función del cazador y regresa al interrogante sin respuesta que construye desentendimiento: 
“¿Quién me responde? Si en la Tierra está la

guerra y la guerra me hace mal. Y si levanto los

dedos implorando por la paz".

Sin embargo, la articulación de preguntas permite que el hablante resalte la búsqueda de la libertad, como una entelequia esquiva que se persigue, pero que no se puede hallar: Libertad, te busco y no te puedo encontrar. Así, la libertad se convierte en una exploración nula y fallida que no puede ser descubierta y que interpela directamente al hablante (te busco).

Sobre este último punto, la persecución de una libertad obstruida y la indignación por la ausencia de respuestas admite una posición mucho más demandante del hablante, puesto que valoriza el escenario comparando con una situación demencial, exigiendo imperturbablemente una contestación y destacando una situación perjudicial:

\section{"QQuién me responde cuando pido que me expliquen el porqué de tanta incoherencia? (...) \\ ¿Quién responde cuando matan? ¿Quién responde cuando hieren? ¿Quién responde si fusilan la esperanza que no alcanza? No sé".}

Esta última pregunta supera a la del verdugo o el cazador y permite entender que el hablante conoce muy bien quién es el responsable. Por esto mismo, parece construir diferentes referencias: a) se dirige al Estado causante del horror; b) a los personajes que asesinaron durante el régimen militar; c) y a aquellos colaboradores de un régimen de violencia.

La lírica alude a la dictadura y las ausencia de respuesta hacia la muerte (matan), las heridas (hieren) y la situación de fusilamiento (fusilan). A partir de la negativa de respuesta ante la censura del estado del ánimo, el hablante se muestra herido en su fe: concluye en un desconocimiento, a sabiendas de la exposición de su propio conocimiento.

La libertad, en tanto, se muestra en la búsqueda y en la falla. Se la postula como un necesario viaje y como un trayecto que debe contener a la vida misma. La respuesta a los interrogantes parece estar en la efectiva y destacada concreción de la libertad que 
incluye a los habitantes de la sociedad, y no solo a los jóvenes del ambiente del rock y el pop.

\subsubsection{Ya no sirve vivir para sufrir}

"No me dejan salir"

Charly García (1983)

Esta canción fue publicada en 1983 y es la sexta canción del segundo disco solista de Charly García, Clics Modernos. El álbum es uno de los más reconocidos del músico por su compromiso lírico y también porque contiene una enriquecedora cantidad de clásicos del rock argentino: "Nos siguen pegando abajo (Pecado mortal)", "Los Dinosaurios", "No soy un extraño", "Ojos de Videotape" y "No me dejan salir".

Clics Modernos es un disco que persigue a la libertad como una idea fija y como aspecto insoslayable. Con esta obra, García se había animado a modificar su modo de producir música y sus modos de construir las canciones (fragmentarias, con instancias crípticas, repletas de refranes).

Por esto mismo, la presentación inicial del disco tuvo ciertas discordancias y generó algunas interferencias entre los seguidores del músico que añoraban la musicalidad sinfónica y/o progresiva de las canciones de Sui Generis o de los álbumes de La Máquina de Hacer Pájaros y Serú Girán. Al respecto, la revista Canta-rock señalaba: "Por eso es tan odiado Charly por mucha gente, porque se anima a ser libre, porque tiró las cadenas y bancate ese defecto (...) El drama de Charly es que solo lo acosan los enemigos y vampiros. Sigue siendo un rebelde, un soñador" (1985: 60).

Clics Modernos es un material que sirvió como marco para comenzar a desarrollar la democracia y para releer lo sucedido en dictadura, haciendo hincapié en los daños sociales y las heridas profundas en lo político y sentimental. Continuando esta idea, Charly García creía en la reconfiguración necesaria que se abría con la democracia, pero también advertía sobre los residuos dictatoriales: "pero el milico interior de cada argentino sigue allí. Ante eso, el rock tiene que decir: ‘¡Váyanse a freír mondongo, locos!' No hay más espacio para hacerse el careta, a la sombra de los misiles, loco, hay que vivir nuestra vida aunque sea de prepo" (Canta-rock, 1985: 61).

"No me dejan salir" es considerado un himno del destape democrático que instaura una situación claustrofóbica y un estado de celebración ambiguo al mismo tiempo. La lírica propone un discurso paradigmático de época que se configura a partir de un marcado 
rechazo dictatorial y de una evidente esperanza de apertura de época. El hablante expresa sus deseos a través de dos destinatarios distintos: por un lado, un interlocutor, dado por verbos en segunda persona, que alude a alguien con quien se plantea una relación de afecto o encuentro (tengo que volverte a ver) y, por otro lado, una segunda persona a quien se le dan consejos u órdenes (te das cuenta, sacate el mocasín).

"Estoy verde, no me dejan salir. Estoy verde, no me dejan salir.

No puedo largar, no puedo salir no puedo sentir amor a este sentimiento, tengo que volverte a ver. Tengo que volverte a ver.

No puedo salir por amor a este sentimiento".

Se observa así la presencia de una tercera persona, (ellos) postulado a partir de la expresión no me dejan salir y que destaca una instancia de control, de represión y de freno para la creatividad o la libertad. En este caso, es posible pensar distintas interpretaciones, puesto que puede referirse tanto a la censura y a las críticas existentes contra el rock-pop argentino como a todo aquello que desde el interior obstaculiza a las personas (los hábitos, los prejuicios o las obsesiones): no puedo pensar, no puedo vivir. No puedo pensar si amor es un pensamiento.

Por esta razón, el hablante expresa una idea voluntativa: ansía identificarse con el sentimiento (no puedo perder por amor a ese sentimiento), la confianza (tengo que confiar en mi amor), el placer (ya no sirve vivir para sufrir), el encuentro con la gente (tengo que volverte a ver) y la informalidad (sacate el mocasín). Particularmente, este último enunciado exhorta al interlocutor y le reclama un modo de vida más simple y auténtico, espontáneo, liberado de las formas (y quizás de los uniformes).

En este sentido, la ansiada recuperación de la democracia no se presenta sólo como sistema político, sino también como un modo de liberación social y de separación de la formalidad y la uniformidad. En el caso de la expresión ya no sirve vivir para sufrir, el placer se contrapone al padecimiento y al sufrimiento (el deíctico ya potencia la situación de enunciación y equivale al adverbio ahora). Los verbos infinitivos salir y parir acentúan una intención de creación y una búsqueda de salida y liberación (no puedo largar, no puedo parir, no puedo salir).

"Tengo que confiar en mi amor, tengo que confiar en mi sentimiento.

Tengo que confiar en mi amor, tengo que confiar en mi sentimiento. 
Ya no sirve vivir para sufrir. Te das cuenta, sacate el mocasin"”.

Se presentan así construcciones sintácticas que indican una seguridad planteada racionalmente y una idea de verdad general. Por ejemplo, la expresión no puedo sentir, si amor es un pensamiento es una construcción condicional que tiene un aspecto de razonamiento y reflexión. Al mismo tiempo, se podría pensar que la lírica no sólo alude a los jóvenes y a los rockeros de siempre, sino también a toda la sociedad cuando se ofrece una reflexión que implica tesón y autodeterminación: no puedo esperar mil años que cambie el viento.

"No puedo calmar, no puedo parir no puedo esperar mil años que cambie el viento.

Tengo que volverte a ver"

Sumado a esto, vale destacar la importancia del color en la letra, puesto que marca la situación negativa que sobrelleva el sujeto: estoy verde, no me dejan salir. El verde ${ }^{41}$ subraya la subjetividad del hablante y tiene un rasgo propiamente negativo, que se construye a partir de un posible juego connotativo: estar verde significa estar harto de la quietud impuesta (no puedo pensar, no puedo vivir). Esta interpretación es válida si se tiene en cuenta además su connotación asociativa con giros lingüísticos del habla coloquial (me ponés verde (...) me hacés sacar canas verdes).

En función de ello, el verde funciona como primer verso de la canción y, asimismo, funciona como un eslogan repetitivo y representativo de la lírica. El color verde presenta otra connotación que por contexto merece destacarse, ya que "No me dejan salir" fue escrita en 1983, año en el que la serie televisiva norteamericana "El increíble Hulk" comenzaba a consagrarse como éxito en la televisión argentina ${ }^{42}$. La elección polifónica de Hulk tiene relación con el núcleo de la historia, puesto que el personaje exhibe una dicotomía emocional extrema: de la serenidad pasa a una irritación absoluta

\footnotetext{
${ }^{41}$ El verde también fue utilizado por Charly García en el tema "Vos también estabas verde", editado en Yendo de la cama al Living, 1982.

${ }^{42}$ La serie se emitió por primavera vez en el año 1977 y llegó a la Argentina hacia finales de 1982. Asimismo, en el videoclip "No me dejan salir", Charly García baila al son del estribillo (estoy verde) mientras mira a cámara con el rostro iluminado en verde, recordando al personaje del programa.
} 
que le confiere la capacidad de aumentar sus fuerzas y acrecentar su furia hasta niveles prácticamente ilimitados (Secul Giusti y Rodríguez Lemos, 2011: 101).

En cierto sentido, este aspecto se relaciona con el discurso que plantea la lírica, ya que se exhiben nociones de cansancio e irascibilidad como consecuencia de un impedimento evidente: la constitución de una libertad individual (no me dejan salir).

\subsubsection{Siempre estás naciendo, libertad}

“¿Dónde estás guardada?”

María Rosa Yorio (1984)

María Rosa Yorio es una de las primeras cantantes del rock argentino y junto a Gabriela $^{43}$, conformaron el selecto repertorio femenino del movimiento durante la década del 70. Yorio también integró las filas de diversos grupos de renombre: fue corista de Sui Generis, se consagró como voz femenina de la súper banda PorSuiGieco ${ }^{44}$ e integró la banda Los Desconocidos de Siempre ${ }^{45}$.

Luego de años de participar en agrupaciones ajenas y de prestar sus voces en otros proyectos musicales, la vocalista editó su primer álbum solista en 1980, pero fue recién con el lanzamiento del segundo álbum que obtuvo una repercusión mayor: Mandando todo a Singapur. Dicho trabajo, producido por un joven y desconocido Miguel Mateos, tiene dos de los mayores éxitos de Yorio, "Fanny da Bola" o "Haciendo el amor en la cocina".

La canción “¿Dónde estás guardada?” se encuentra en el noveno lugar del cuarto disco de Yorio, editado en 1984 y titulado Por la vida. Esta obra fue una de las últimas que colocó a Yorio en un lugar de exposición, puesto que con los materiales que publicó ulteriormente la repercusión masiva bajó drásticamente. No obstante, Por la vida la ubicó también como una de las voces femeninas más conocidas e incluso precursoras de la cultura rock local.

Específicamente, “¿Dónde estás guardada?” postula a la libertad como a una figura solitaria y desprotegida que intenta renacer luego de los avasallamientos y las persecuciones. El hablante postula a la libertad como la principal protagonista del

\footnotetext{
${ }^{43}$ Cantautora de rock, folk y jazz que editó su primer disco en 1972, titulado con su nombre.

${ }^{44}$ Banda de folk formada por Charly García, Raúl Porchetto, Nito Mestre, León Gieco y María Rosa Yorio.

${ }^{45}$ Grupo fundado por Nito Mestre, tras la disolución de Sui Generis.
} 
discurso, y la referencia a la primera persona del singular predomina durante toda la enunciación (sólo se utiliza la pluralidad hacia el final). En este sentido, la modalidad de enunciación interrogativa persiste durante el derrotero de la lírica, como un eje continuo de reflexión sobre la puesta en común la libertad en una post-dictadura, anunciando posibles amenazas, provocaciones y dificultades en un nuevo contexto.

\section{“¿Dónde estás guardada tan sola, dónde? ¿Dónde vas tan loca, hoy? ¿Quién te roba el sueño? ¿Y quién te escondió lejos? ¿Dónde estás guardada, libertad?”}

Por esta razón, los interrogantes destacan una situación en la que la libertad se encuentra guardada, ocupada y desatada (tan loca, hoy), desde el tiempo presente, evidenciado a partir de la deixis temporal una situación contextual vivida. Así, la construcción discursiva de la libertad se encuentra emparentada con una locura del momento, que, desde el refuerzo de la palabra tan, permite una interpretación de mayor intensidad en relación con la descripción del contexto.

El hablante busca la libertad para reconocer un oponente y comprender el adversario de esa actualidad contextual. Se establece entonces, una duda sobre el rival que se tiene en la actualidad programada (hoy), desconociendo el obturador de los sueños colectivos. En función de ello, las preguntas resultan insistentes, porque examinan el pasado reciente de la dictadura y esconden una responsabilidad sobre el ocultamiento de la libertad en otros tiempos.

Precisamente, la lírica expone un temor acerca de la efectiva exposición de la libertad. El yo de la lírica se interroga constantemente por el refugio y construye una necesidad: precisa saber en qué lugar se encuentra esa libertad (como personaje, como figura simbólica) porque presiente acontecimientos contrarios y sensibles en torno a su constitución. El yo entiende que la libertad puede ser poderosa en su práctica de locura, pero también puede ubicarse en zonas frágiles que podrían debilitarla: te ves tan casada de esperar ¿Dónde te podemos visitar?

Si bien el locutor construye un temor y destaca cierta inestabilidad en esa libertad, también reconoce que se encuentra victoriosa en el contexto porque aquella situación negativa, que podríamos vincular con la dictadura, ya no puede atrancarla ni cercenarla porque existe un panorama de fortalecimiento, sin funciones ni acciones para atormentar: "A quién te roba el sueño se le va acabando el sueño". 
El régimen militar es expuesto así como un oponente que aparece de un modo amortiguado, como en una instancia de quiebre. A pesar de ello, su poderío radica en la posibilidad de robar los sueños que permiten consagrar la libertad en la sociedad (el propio hablante padece esa situación residual del temor). Esta situación dual, de sentimientos encontrados, que aprecia a la libertad desde su fragilidad y desde su sentido de corte y transformación, es resuelta a partir del discurso de esperanza:

"Una canción te reclama.

Es casi del alma el grito que te está buscando y que nos va a contar dónde estás guardada,

Libertad".

En función de ello, la lírica advierte que su discurso guarda un reclamo, un pedido, una imploración que proviene de lo más intrínseco de la sociedad que anhela la puesta en común de las libertades. Se construye así una idea de alarido, de grito ansiado que, además, busca y cuenta, narra, describe (al nosotros) y dice dónde se ubica la libertad para todos.

Si bien el contexto parece acompañar la práctica de las libertades, la autonomía no está dicha aún, sino está a la espera de encontrarse a la vista. En este sentido, el pasado reciente tiene total responsabilidad en la ausencia de plenitudes:

\section{"Debajo de muchas botas, entre el miedo y el silencio, allí estás muriendo, pero dentro nuestro siempre estás naciendo, libertad".}

La libertad es entendida desde los residuos de la dictadura, como un símbolo de esperanza ante el terror y la censura de los años más oscuros del país. Desde una posición positiva, la temática de lo libre es construida como una protagonista solitaria, loca, que vive del reclamo y que nace en cada hombre (dentro nuestro siempre estás naciendo, libertad). Asimismo, desde una visión negativa, se articula como víctima de las situaciones más abrumadoras del autoritarismo militar: sus desestabilizaciones, sus sofocaciones y sus avasallamientos individuales (debajo de muchas botas, entre el miedo y el silencio, allí estás muriendo) 
En esta última, el empleo del adverbio allí resulta contextual, pero también precisa una combinación deíctica al destacar un contexto particular de hundimiento dictatorial. No obstante, pese al desdoblamiento, la esperanza no se encuentra afuera, en el clima de época, sino en el interior de los sujetos. La libertad no se halla en la muerte, sino naciendo (siempre) y retornando de los lugares más crueles.

\subsection{Consideraciones parciales}

\section{Transición, retirada militar y construcción discursiva de la libertad}

Las líricas que integran este capítulo contienen las expectativas, las transformaciones y los sentidos de libertad producidos a causa del fin de la dictadura militar y el desarrollo de un reordenamiento democrático. Se reconocen así modos de ver y sentir social que mutan y destacan argumentos críticos, vinculados con desigualdades y complejidades propias de un país en reconstrucción.

El modo en que cada lírica construye su discurso se encuentra en franco y tensionante diálogo con lo que dicen otros y lo que se percibe de las acciones de esos otros. Por esto mismo, las líricas reconsideran, responden y adaptan a sus antagonistas en relación con el escenario de enunciación y de proposición contextual.

Las disputas de los sentidos se tejen a partir de negociaciones y renegociaciones con lo decible. Las letras expuestas responden a procesos complejos que enlazan, atraviesan y retroalimentan lo más íntimo de cada experiencia individual con procesos compartidos, de un modo o de otro, por una colectividad.

Se entiende así que la libertad es asimilada en virtud de distintas tramas particulares y propias de un período de transición democrática. En consecuencia, se advierte una discusión en torno a 1) los lugares de disputa en las prácticas discursivas y los espacios del universo del rock-pop argentino; 2) los discursos minoritarios o mayoritarios (masivos) postulados en el espacio social de la juventud y los participantes de la cultura rock, y 3) la construcción de lenguajes y discursos que narran y complejizan el pasado dictatorial.

En este sentido, la construcción del oponente que presentan las líricas es remarcado a partir del colectivo ellos que se relaciona con las instancias negativas y dolorosas provocadas por el régimen militar: la desaparición y la muerte ("Ellos nos han separado"), la desigualdad social y el resquebrajamiento económico-social del país 
(“Su, me robaste todo") y los temores residuales, continuos y vigentes luego de la guerra de Malvinas ("Buenos cimientos").

En tanto, la integración del nosotros ensaya diferentes preguntas sobre la libertad: por un lado, se encuentra sujeta a los avasallamientos de otras épocas ("Ahora estoy en libertad") y a las prohibiciones que persisten en la sociedad luego del terror y la persecución política y cultural ("No me dejan salir"); por otro lado, las líricas articulan una evocación de la esperanza que tematiza sus instancias emocionantes y emancipatorias ("Inconsciente colectivo"), las posibilidades de estar alerta aún en un contexto favorable ("Viaje a la libertad") y las intenciones voluntaristas de preservación (“¿Dónde estás guardada?”).

De esta manera, también existe una enérgica articulación entre la memoria y la identidad, tanto personal como colectiva, destacadas a partir del racconto histórico y social en tiempos de dictadura ("Su, me robaste todo"), y en función de los marcos autoritarios y violentos de ese régimen ("Ellos nos han separado", "Ahora estoy en libertad"). Ante esto, la reflexión sobre las características del llamado pasado cercano advierte un avance en relación con las distintas memorias sobre el pasado reciente argentino que construyen las líricas incluidas en este capítulo. Se presenta así un campo semántico que reúne adjetivaciones y sustantividades referidas al terrorismo de Estado, señaladas de un modo poético y también de una forma descriptiva: prisión, cadenas, condena, miedo, dolor, fusilado, botas, silencio. 


\section{Capítulo VI}

\section{Una estrategia de defensa}

\subsubsection{La libertad como centralidad democrática}

El retorno de la democracia a la Argentina produjo una instalación cultural vinculada con la convivencia, el acuerdo y el compartimento. De esta manera, se habilitó un mecanismo articulador de debate político que actualizó un camino de reflexión hacia una democracia sustentada en la libertad, la creación y la contingencia con el propósito de ver el mundo y lo político desde una posible trasgresión de los límites.

En pocas palabras, la construcción discursiva de la libertad que se forjó en el ocaso de la dictadura se constituyó a partir de la reivindicación de la lucha democrática y el rechazo del autoritarismo y el avasallamiento de las autonomías. Así, la ética de la democracia se fundó en una idea de libertad y justicia en pos de la equidad, como distribución de las ventajas y los sacrificios (Ollier, 2009: 235).

La recuperación de la democracia trajo consigo otras recuperaciones, como por ejemplo, la de la confianza en las instituciones, la de las palabras, de los pensamientos, de las ideas y decisiones (Ulanovsky, 2008: 17). Si bien el período de enamoramiento luego se tornó fugaz, es posible apreciar que se generó un idilio social con la apertura democrática: "Era 'el alboroto de la democracia' en su máxima y mejor expresión, sin que la advertencia de 'orden, pero con libertad', atemorizara a una sociedad harta de rigidez (...) que deseaba encaminar el país hacia la consolidación de un sistema desconocido" (Ferrari y Pérez, 2013: 403).

Como señalan las investigadoras Ariana Reano y Julia Smola, la democracia determinaba las formas de participación ciudadana y los límites representativos de los gobernantes. En consecuencia, la instalación del sistema instauraba un debate que involucraba a una sociedad que acompañaba y marcaba el paso de la transición democrática:

En efecto, junto a los discursos políticos e intelectuales, podemos «escuchar» en las voces de la ciudadanía la repetición y la actualización de esta tensión democrática (...) Así, los escenarios político-institucionales de la transición -las urnas, el parlamento, los tribunales de justicia, incluso las instancias más duras de negociación con los militares- fueron acompañadas de grandes movilizaciones 
populares que constituyeron los otros escenarios políticos de la transición -las calles, los estadios, las plazas- en donde esta tensión democrática se hacía sentir en discurso y en acción (2013: 3).

En función de ello, la democracia se representaba como una utopía de la libertad y un tránsito hacia la igualdad. En términos de Rinesi la instancia democrática del posautoritarismo postulaba, en efecto, una utopía de la plena realización de la libertad o de las libertades, situando un debate conversado, discutido y sustentado durante la "transición democrática". La libertad era un programa que operaba como una centralidad en la agenda pública de la transición y que funcionaba como garantía de construcción o asilo de esperanzas.

En virtud de lo diagramado por el gobierno de Alfonsín, la democracia se asociaba con la fuerza movilizadora, la libertad o la ética y se oponía a otros como la inmoralidad pública o el autoritarismo. Si bien, en el diagnóstico de la situación, la gestión radical destacaba las secuelas tanto culturales, como políticas, sociales y económicas que había dejado el régimen autoritario, vale decir que solo establecía la prioridad de restauración de las dos primeras (Elizalde, 2009: 70).

En este juego de oposiciones, huelga decir que el aparato represivo de la dictadura desempeñaba un rol preponderante porque había avasallado los preceptos propios de un sistema democrático como el de la libertad individual. En este sentido, el sistema democrático se conformaba como un valor esencial que debía ser defendido en su totalidad. La libertad individual entonces, se concibió como la consagración y el límite mismo de la libertad, como el modo, quizás, de unir desigualdades en tiempos de transición democrática.

De esta manera, se impuso de un modo más ferviente una estrategia de defensa de esos valores con el objeto de contener las bondades de la democracia. Estos aspectos, son posibles de ser encontrados en las líricas de rock argentino dispuestas en este capítulo porque se encuentran atravesadas por nociones que postulan libertades de acción y voluntades de liberación que se relacionan con un escenario de reconstrucción social.

\subsubsection{Jóvenes en transición}

La democracia trajo consigo una nueva concepción social, construida en los intersticios de la última dictadura militar y a partir de las fisuras provocadas por la represión y las 
desapariciones. En términos del periodista, poeta y psicoanalista Carlos Luís Galanternik, más conocido como Tom Lupo, la democracia se constituyó a partir de una mezcla entre el vital desorden de los jóvenes y el estallido de la cultura: "una libertad de todos los sexos, tareas pendientes con los que menos tienen, una forma de la renguera humana...pero prefiero infinitas veces esos pasos vacilantes al recuerdo de los supuestos pasos firmes de botas pisoteando hasta el último resto de dignidad humana" (2006: 71).

Por esta razón, comenzaron a dibujarse incógnitos contornos culturales y políticos que se vinculaban con un lenguaje de convivencia social y política de orientación pacífica, anunciando pasajes de defensa de los valores de la libertad, la tolerancia, la seguridad personal y la importancia de la vida humana (Camou, 2007: 41).

Los jóvenes de la transición democrática formaban parte de una sociedad en reconstrucción que reponía sus instituciones (políticas, culturales, económicas) y desarrollaba prácticas en un escenario de re-configuración estatal y de creación paulatina de espacio democrático. La definición de la transición democrática, en este caso, se encontraba atravesada por discursos y condiciones de producción que reflexionaban lo sucedido en la década del 70 de un modo polarizado, sin inmiscuirse profundamente en las responsabilidades políticas y criminales del Estado.

En este aspecto, existía cierta visión juvenil que exponía una perspectiva expurgada y ajena de un pasado de disputa política a partir de la lucha armada. Las actitudes de los jóvenes durante la denominada "reconstrucción democrática" se profundizaron a partir de la memoria y las demandas de justicia que se enlazaban con las tareas de la reconfiguración del estado y el nuevo pacto de la sociedad después de la guerra de Malvinas. Sin embargo, el concepto de "reconstrucción democrática" forjó hábitos, formas, valores y nociones democráticas en los jóvenes que se orientaron hacia las nociones libertarias y propiciaron manifiestos artísticos (el rock, por ejemplo) en pos de la consolidación democrática.

La apreciación de la democracia, en tanto conjunto de procedimientos institucionales, permitió procesar conflictos sociales que no formaban parte del conjunto de imágenes que los jóvenes del 60 y del 70 colocaban en juego. Ante esto, es posible apuntar que dichas generaciones veían a la democracia como una eficaz y peligrosa pantalla que ocultaba las verdaderas relaciones de dominación y combinaba la desconfianza hacia los mecanismos de representación, reforzada por la proscripción del peronismo y más adelante de los partidos en conjunto. 


\subsubsection{La búsqueda de libertad}

Hacia la década del 80, la juventud se ocupó de redefinir los debates acerca de la libertad y, del mismo modo, el rock argentino escoltó las cosmovisiones de los jóvenes en torno a los valores democráticos. Tanto la renaciente democracia argentina como las atrocidades cometidas por la dictadura militar incidieron en las visiones propuestas: la democracia contenía aires de libertad y resultaba imperante su defensa.

El discurso de los jóvenes se vinculó, desde el rock, con una semantización cotidiana y espontánea, con niveles de connotación que subyacían las libertades propias. Tras la apertura democrática, se estableció una relación jóvenes-rock que postulaba la conformación de un ideario democrático que tenía como objeto la consolidación de un estado de derecho, diverso y de rechazo opresivo desde 1983 en adelante.

El rock argentino se relacionó con los jóvenes a partir de los modos de comprender la política y su asociación a la vida y a la muerte en un contexto democrático, manteniendo la memoria del horror impuesto por la dictadura cívico militar. Igualmente, el discurso del rock se emparentó con el de los jóvenes en pos de interpelar a la sociedad violenta, la moral castradora y las definiciones autoritarias. De este modo, contribuyó a la construcción de caminos e ideas en virtud de la consolidación de valores, aspectos democráticos y abordajes identitarios, concentrando a partir de sus discursos un sentido esencial de compartimiento, intercambio y puesta en debate con el oyente-espectador-lector juvenil.

De la misma manera, se multiplicaron las interpelaciones sociales y políticas del rock argentino hacia los jóvenes (Semán, 2006: 8) y aparecieron representaciones sociales que atravesaron demandas apropiadas por los jóvenes urbanos de un proceso de reconstrucción democrática. El rock argentino se enmarcó en un proceso de transformación de construcción de sentido $\mathrm{y}$, por resto mismo, modificó el manto protector de las variantes estilísticas y generó mayor diversidad de narrativas y apreciaciones juveniles desde una noción de libertad.

Sobre este punto, en su número especial por lo primeros veinte años de fundación del rock argentino, la revista Canta-rock señalaba que la libertad debía forjarse porque no era una cuestión que se ganara instantáneamente: "No sale como el sol, sino es preciso amasarla como el pan (...) La libertad no es una meta: es un trampolín. El reto es nadar, saber elegir la dirección, y aprender el difícil oficio de gambetear tiburones" (1985: 42). 
El rock argentino buscaba afianzarse por y a partir de los medios de comunicación con la intención de escalar singularidades y simbolismos en torno a la libertad. A partir de ello, la divulgación de las producciones del rock se encontró atravesando fronteras y creando ligazones con una industria cultural de una forma inédita, puesto que desde sus inicios había sido menospreciado por la cultura oficial.

Como sostenía la revista Canta-rock en su reconstrucción especial sobre el aniversario del rock argentino, las elecciones nacionales que promulgaron a Alfonsín como presidente trazaron una línea definida en la realidad cotidiana de la juventud argentina: "La certeza de cambio político en el país, dio a los rockeros más espacio que nunca en la difusión masiva, tanto en capital como en el interior. El tema era 'la libertad', y el hecho de poder manifestarse sin temor a desaparecer marcó la primera gran diferencia general” (1985: 22).

\subsection{Análisis de las líricas}

Las líricas que se presentan a continuación, detallan una situación de defensa de la libertad y desarrollan reflexiones sobre su presencia en un contexto democrático. Se analizan así nueve líricas que articulan una discursividad que tematiza en torno a la preservación del ser libre y sus continuidades en un proceso de configuración social:

1) "Ir a más" de Los Abuelos de la Nada articula un discurso de libertad vinculada con lo sentimental y lo afectivo. Desde esta perspectiva, la defensa de lo libre se postula con una búsqueda de movimiento y con una voluntad de generar alegría como vehículo de libertad.

2) "Soy tu bandera", también de Los Abuelos, tematiza a la libertad desde un lugar poético, conceptualizando a la libertad como causa y emblema a defender y salvaguardar.

3) "Libertad de pensamiento" de Alejandro Lerner, verifica un entendimiento de la libertad relacionado con un espacio para recrearse y forjar nuevas perspectivas en conjunto, sin distinciones ni conflictos.

4) "Manifestación de escépticos (So' lo ma' grande libertad)"de Sueter incluye y sustenta un discurso de libertad como alabanza y referencia para la paz, pero desde una modalización irónica y con referencias coloquiales. 
5) "Una canción diferente" de Celeste Carballo articula una estrategia de definición de la libertad diagramada desde la visión de la mujer, narrando una relación tortuosa de amor y un discurso que propone un posicionamiento de género.

6) "Nada me detiene" de La Torre construye una situación discursiva de reflexión y de ofensiva, también desde la perspectiva de mujer. Se presentan así enunciados que defienden una libertad individual y se contrapone a los ataques que intentan coartar las independencias.

7) "Nunca podrás sacarme mi amor" de Fito Páez expone una toma de posición y una defensa del amor y de la libertad de amar como posibilidad de cambio y de obstinación. Así, se construye una consideración de la libertad vinculada con el amor de hacer, crear, creer y vivir en sociedad.

8) "Yo no me sentaría en tu mesa" de Los Fabulosos Cadillacs es una lírica que se construye a partir de la preservación de la libertad, la elección el rechazo del avasallamiento y las críticas de sectores tradicionales o convencionales.

9) "Salgamos a la calle" de Man Ray invita puesta en común de las prácticas en el espacio público, con la conciencia de la defensa de la libertad en un escenario que incluye y que no resguarda las intenciones.

\subsubsection{La energía de ir a más}

"Ir a más"

Los abuelos de la Nada (1982)

La banda Los Abuelos de la Nada fue creada por un joven Miguel Abuelo en el año 1967 y relanzada con otra formación, con identidad de agrupación y con un estilo musical diferente a partir de 1981. El disco debut de esta segunda etapa fue producido por Charly García, se tituló de un modo homónimo y significó el comienzo de un nuevo curso exitoso que no se relacionó en absoluto con las coordenadas marginales planteadas por Abuelo durante la década del 60 .

El álbum Los Abuelos de la Nada se editó en 1982 y obtuvo un éxito muy repentino a partir de la rotación de las canciones "No te enamores nunca de aquel marinero bengalí", "Sin Gamulán” (cantada por un joven e ignoto Andrés Calamaro) o "Tristeza de la ciudad" (en la voz de Gustavo Bazterrica). De acuerdo con la revista Canta-rock, el disco proponía una situación refrescante en tiempos desmoralizantes por la derrota de 
Malvinas y el ocaso de la dictadura: “el objetivo era levantar esos 'cachetes caídos', provocar el baile" (1985: 20).

Hasta su fallecimiento en 1988, Miguel Abuelo supo dotar de expresiva poesía el repertorio del rock, apelando a un lenguaje romántico, festivo y en ciertas instancias, críptico. En términos del músico Miguel Cantilo, hacia la década del 80, las temáticas de Los Abuelos de la Nada apuntaban a despertar en la gente la libertad de gozar los beneficios energéticos del rock: "Bailar entre vasos y besos, imaginar marineros bengalíes y mujeres barbudas proclamando himnos del corazón refrescaba notoriamente al pensativo y conflictuado rock, ya libre" (2011: 190).

Tras el lanzamiento del disco debut de la nueva formación, Abuelo buscó su propia definición sobre la reconfiguración temática de sus líricas: "Ahora hay que ponerse a favor y agarrar cada uno su barco y no delirar demasiado. No es que le rock deje de ser delirio, pero ahora debe ocupar su verdadero rol dentro de un país democrático. Una realidad en un país con apertura" (Guerrero, 1994: 72).

Particularmente, la canción "Ir a más" está ubicada como quinta pista del disco Los Abuelos de la Nada. La propuesta de la lírica convoca una instancia novedosa, valorada a partir de una apertura de nuevos tiempos, y expone un afán de libertad mucho más vivaz y evidente que en las letras analizadas en el capítulo previo. Al respecto, el discurso articulado expone una concepción de libertad defensiva y realiza un abordaje sobre la libertad y su modo de aplicación en la vida cotidiana, social e individual en víspera democrática.

En este sentido, tanto la identidad del canto (cantando) como los denominados nuevos tiempos se funden en una idea de compartimiento y ánimo colectivo, en el que el yo de la lírica se ubica dentro de una noción de novedad y sentimiento de alegría, que modaliza sus posturas y busca la identificación: ahí vas, mi dueña. Hoy me haces sentir, veremos nuevos tiempos, que hay que compartir.

A partir de esta estrofa inicial, se advierte una primera persona que se dirige a un alocutario femenino (mi dueña) y destaca un presente de celebración que se enmarca en función de una marcación deíctica temporal: hoy. De este modo, se resalta un ideario de compartimiento y de vivencia particular en un marco de novedades o de instancias de apertura que dan cuenta de una urgencia o una prontitud.

La noción remarca una labor activa, con verbos de movimiento, actuación, realización y participación colectiva, como por ejemplo: ir, hacer, ver o compartir. La generalidad de 
la novedad, en este sentido, propone una subjetividad que indica una renovación, de orientación distinta o diferente en relación con lo existente o lo apre(h)endido

Se reconoce así un desplazamiento de relación que parte desde la indicación deíctica espacial (ahi), dirigida a la segunda persona (me haces) y apreciada en función de un pedido de participación mutua que incluye al mismo interlocutor desde el nosotros (veremos nuevos tiempos). En tanto, a partir de la modalidad imperativa y aseverativa se expresa una relación interpersonal, respectiva, en la que el hablante se compromete con el alocutario (veremos nuevos tiempos) y le exige una intervención activa y colectiva en el nuevo panorama (hay que compartir).

"Voy cantando, voy amando, voy jugando, voy a más.

Si Buenos Aires despierta, yo digo, se despereza.

Siente libertad, busca la alegría de ir a más”.

A partir del presente enunciado, se subraya la continuidad de una primera persona que se encuentra en movimiento y que, a partir del empleo del gerundio, enmarca su propio traslado de existencia. En este contexto particular, el gerundio permite una conjugación del verbo que construye un modo adverbial y enuncia así una continuidad y sensación de actividad. De la misma manera, se resalta la particularidad del adverbio compuesto más, que refuerza una potencialidad y denota una idea de exceso, aumento, ampliación o superioridad. Igualmente, su empleo en el discurso permite pensarlo como un vínculo con los verbos que aplican un des-aturdimiento: despertar, desperezar, sentir, buscar.

“Voy cantando, voy amando, voy jugando, voy a más.

Si Buenos Aires despierta, yo vivo ser...".

Se advierte entonces una percepción agradable y esperanzadora del contexto: los verbos cantar, jugar, amar, despertar, vivir, ir (voy) comparten un rasgo isotópico de orientación positiva y con una propensión de autenticidad. La búsqueda se sitúa a partir de la interrupción del entumecimiento, la renovación de una memoria olvidada o la excitación de un movimiento que se logra al desperezarse.

En este sentido, Buenos Aires (como ciudad, espacio o lugar de simbolismos) no se despierta de un letargo, sino resurge a partir del des-perezamiento. La ciudad de Buenos Aires aparece como una unidad urbanística que se encuentra en un 
resurgimiento integrador $\mathrm{y}$ articulador. Este entendimiento se diferencia de los postulados hippies de los 60 que planeaban una vida alejada de las metrópolis y en contacto con la naturaleza: la ciudad, en tiempos de transición democrática, se comprende como un espacio de lucha, de supervivencia y también de vida.

Al respecto, el hablante profesa una libertad que enlaza un sentimiento agradable, de placer, exteriorizando la oportunidad de sumar y alcanzar una mayoría (siente libertad. Busca la alegría de ir a más). El sentimiento, en este caso, se presenta como un deseo o necesidad de acción articulada por el locutor: ruge mi moto, nena. Voy a tu garaje. Vos sos tan loca y buena, yo quiero ir a más.

A partir de este último enunciado, se puede remarcar que, en primer término, el locutor continúa en la senda modal del imperativo (ruge mi moto); en segundo lugar, admite la dirección hacia la segunda persona (vos sos tan loca y buena) y resalta así la carga positiva del carácter disparatado e imprudente del adjetivo loca y la bondad, utilidad y diversión del adjetivo buena. Por último, el hablante regresa a la noción de la primera persona que renueva su actualidad y no ofrece matices (voy a tu garaje, yo quiero ir a más").

"Si mi máquina es veloz, será porque pienso en llegar.

Siempre libertad, busca la energía de ir a más”.

En el siguiente enunciado se articula un escenario de justificación, que propone una idea de vértigo y que instaura una idea de alcance. Ante esto, conviene preguntar $i$ a donde se intenta llegar? El sentimiento de libertad parece ser el faro y la zona necesaria para efectivizar y alcanzar el objetivo de un desplazamiento particular. En este aspecto, la búsqueda de la libertad se relaciona con la energía, que postula una instancia de fuerza y vigor determinado. Aquella postulación de sentimiento o de libertad se enlaza con la particularidad del adverbio siempre, una concepción temporal que simboliza una actualidad constante y persistente. Así, resulta relevante destacar la idea de ir a más y de energizar así la perspectiva del locutor.

"Ven, a mi banda, nena. No te hagas rogar.

No quieres más sistemas. Te atragantarás”. 
La idea de liberación, en este caso, también se relaciona con el alejamiento de sistemas, que se nombra como un ente abstracto que podría considerar reglas o principios sobre una materia racional. Los sistemas se postulan como ataduras que bloquean o turban las expresiones y las vuelven rutinarias. En esta estrofa, de hecho, el locutor le habla directamente a un alocutario denominado con el modismo coloquial nena. La libertad se disputa, por consiguiente, como un botín que define una negativa hacia lo sistemático (no quieres más sistemas), puesto que se lo acopla con el ahogamiento y/o el atoramiento de un futuro inmediato (te atragantarás).

"Ven cantando, ven bailando, ven jugando, ven a más. Gente, libertad, busca la alegría de ir a más”.

Este enunciado final, por cierto, remarca una continuidad imperativa por parte del yo de la lírica, puesto que le ordena a la segunda persona un acto de desplazamiento, de actuación y renovada acumulación. Se prosigue así en el empleo del gerundio y, de esta manera, se destaca la presencia de la libertad relacionada con la actualidad, el sentimiento y la propia idea de gente o pluralidad de personas y seres de la expresión (gente, libertad). El imperativo continúa asignándose hacia la búsqueda desde el tiempo presente, la alegría y el efecto de indagar más: busca la alegría de ir a más.

\subsubsection{Arte de los decididos}

"Soy tu bandera" Los Abuelos de la Nada (1983)

"Yo soy tu bandera" es una canción de los Abuelos de la Nada que integra el tercer lugar de la segunda placa de la renovada banda, titulada Vasos y Besos. El disco, editado en 1983, significó un aluvión de éxito para la banda, tanto por la propuesta musical como por las líricas de las canciones ya clásicas en el universo histórico del rock argentino: "No se desesperen”, “Chalaman” (en la voz de Daniel Melingo), “Así es el calor" y "Mil horas" (ambas cantadas por un Calamaro cada vez más reconocido).

Especialmente, "Yo soy tu bandera" muestra la importancia que tiene el ideario de libertad en un rock argentino que palpitaba el final de la dictadura militar. Por esta razón, es una letra que se vincula directamente con el pensamiento libertario de la 
década del 60 y que se entrelaza con los pensamientos de la famosa "generación beat"46 que influenció de un modo determinante a los primeros rockeros de argentina: Litto Nebbia, Tanguito y, por supuesto, Miguel Abuelo.

Esta letra, que fue editada en plena víspera del retorno democrático, se encuentra atravesada por los discursos de efervescencia democrática que atravesaban dicha época. A partir de ello, la construcción discursiva que se aprecia se vincula con una libertad en estado poético, definiéndola de un modo cercano, intrínseco y con una intencionalidad sentimental.

Los Abuelos de la Nada proponen una constitución de patria, bandera y libertad despojadas de las vinculaciones militares. Se propone así una libertad embanderada y abrazada a las integraciones y las heterogeneidades: "Una subjetividad instituida en tabernáculo de la libertad, exhibición libertaria radicada en su propio cuerpo, medio e instrumento de la alegría de la libertad (...) que no duda en inmolarse como bandera de gozo en el ritual de la libertad (Blanco y Scaricaciottoli, 2014: 71).

Al respecto, la libertad es construida alegóricamente como una colega de la vida, fidelizada por las propias prácticas de los seres humanas y como una pericia resuelta y desarrolladora del ser:

\section{"Libertad, hermana de los amigos}

Libertad, nada me ata y estoy vivo.

No te mueras nunca, Libertad".

En este sentido, el contexto circundante que acompaña la lírica permite diagramar un escenario de expectativas e incertidumbres expuestas. Si bien no es la primera canción en la que Los Abuelos de la Nada hacen alusión a la libertad, "Soy tu bandera” presenta una enunciación simbólica que intenta explicar lo libertario de una manera individual y de una forma positiva. Se advierte así una subjetividad que exhibe una decisión libertaria destinada a un propio cuerpo, desde un aspecto de defensa y alegría.

El yo de la lírica, enunciado a partir de la primera persona, organiza su propuesta desde un primer momento: reniega del autoritarismo y desprecia aspectos y experiencias que

\footnotetext{
${ }^{46}$ La llamada Beat Generation refiere a un grupo de escritores estadounidenses de la década del 50 que se destacó por plantear un marcado rechazo hacia los valores religiosos y tradicionales de Norteamérica. Dicha generación se caracterizó por seguir las coordenadas de filosofías alternativas, por el uso de drogas alucinógenas y la defensa de libertades sexuales para todos los individuos, entre otros.
} 
ya no quiere vivenciar (nada me ata y estoy vivo). De hecho, en este último enunciado se destaca una intención declarada y significativa: el hablante se muestra con intenciones de vivir y, en consecuencia, se podría vincular esta idea con la realidad tormentosa creada por la última dictadura militar: Libertad, socia de los peregrinos. Libertad, luz, coraje, amor divino con el corazón.

En función de lo expresado en esta estrofa, la libertad es tematizada en virtud de una actitud y una conexión que los sujetos desarrollan en su interior porque se identifica con la luz, el coraje, el amor y la divinidad (amor divino). Las cargas valorativas y sustantivadas presentan una intensidad positiva y se relacionan con lo proveniente del corazón (un concepto que en la modernidad significa el afecto, el cariño y los sentimientos): Quien no te comprende te vulnera, novia de Dios.

Por tanto, la libertad opera discursivamente como la novia de Dios y es considerada como un emblema que se suele vulnerar porque no se la pretende interpretar ni se le concede el desarrollo: quien no te comprende, te vulnera, novia de Dios. En este enunciado, por tanto, se observa que el hablante postula a la libertad como su interlocutor: la libertad resulta importante para establecer una confesión y una consideración apasionada:

\section{"Libertad, arte de los decididos.}

Libertad, nada me ata y sigo vivo, yo soy bandera, Libertad"

Asimismo, desde un aspecto extralingüístico, puede pensarse que, como estandarte y líder de otras épocas del rock argentino, Miguel Abuelo se presenta, a partir de esta letra, como un defensor de la idea de libertad, resguardando su valor y revelando su intensidad como una bandera que debe enarbolarse. Quizás, a raíz de ello es que deposita cierta proyectualidad e incluye a los individuos sociales como preservadores de la divulgación y manutención de la libertad: yo soy tu bandera. La libertad, por esto mismo, se considera como un arte y una decisión. Es decir, como una causa y un emblema a defender y salvaguardar ante cualquier acto de persecución o ataque de expresión. 


\subsubsection{Para elegir y actuar}

"Libertad de pensamiento"

Alejandro Lerner (1984)

Alejandro Lerner es uno de los artista más reconocidos de la escena musical argentina que, pese a lo que puede suponerse actualmente, integró las filas del rock argentino de los 80 tras su participación como invitado en las bandas de Raúl Porchetto, León Gieco, Miguel Cantilo o Piero y su colaboración en las agrupaciones Soluna y Los Desconocidos de siempre. El primer disco de Lerner, denominado Alejandro Lerner y la magia, fue editado en 1982 y logró un suceso importante luego de presentarse en el recordado festival "BA Rock IV" del mismo año ${ }^{47}$.

Del mismo modo, el siguiente álbum, titulado Todo a pulmón, significó un despegue en la carrera del solista a fuerza de la difusión de "Todo a pulmón" y "La isla de la buena memoria", dedicada a los caídos en la guerra de Malvinas. Este material, conocido como Lernertrés, tiene la particularidad de ser uno de los últimos trabajos considerados bajo el rótulo de pop-rock, puesto que de allí en adelante Lerner se orientó hacia la música romántica y la composición de baladas. No obstante ello, se lo reconoce como partícipe de la corriente rock-pop de los años 80 al igual que Sandra Mihanovich y, en menor medida, Alejandro del Prado o Marilina Ross.

Lernertrés siguió la senda de éxito del disco anterior y obtuvo buenas críticas tras la rotación de canciones cada vez más orientadas al universo romántico como "No hace falta que lo digas", "Nada más, nada menos" o "Canta una canción de amor". Al respecto, Lerner señala que fueron los medios periodísticos los que lo tildaron de rockero en tiempos de dictadura, pese a su pasado como músico de jazz o folclore: "Eran épocas muy jodidas, te llevaban, te detenían. Había sufrido tanta persecución y miedos que, cuando salí a cantar, lo hice con una bronca y una irreverencia y con unas ganas de cambiar las cosas" (Rolling Stone, 2002: 60).

"Libertad de pensamiento" se publicó como sexta pista del exitoso tercer álbum y cuenta con la presencia de un locutor que postula a una segunda persona (vos) desde una instancia interpeladora. Del mismo modo, emplea estratégicamente el uso de primera persona del plural, con intenciones de inclusión y negociación frente una segunda del

\footnotetext{
${ }^{47}$ Evento de organización musical que tuvo cuatro ediciones y que se erigió hacia 1970 como el primer festival de rock realizado en la Argentina.
} 
plural en quietud y suspensión. El desplazamiento parece seguir una línea que se inclina desde el empleo del ustedes, para continuar en el nosotros y finalizar en el vos. Por esta razón, el juego de leitmotiv y enunciados de aspecto concluyente, refuerzan una argumentación en torno a la defensa de la libertad y, sobre todo, el anuncio de un pensamiento autónomo y discontinuado:

\section{"Perros y gatos, seres humanos. Todos buscamos \\ libertad. Armas de fuego, juego de manos.}

Ya no se equivoquen más”.

El hablante dispone de modos que naturalizan situaciones y exponen una construcción de sentido común que no debería eludirse si la propuesta es alcanzar la libertad. De esta manera, los aspectos de la violencia se alejan de la propuesta de libertad, apelando así a hechos conducentes que podrían concluir en una equivocación de orden individual y colectiva. Ante esto, el planteo activa un ideario de "toma de conciencia" o reflexión en relación con el hecho de convivir en una sociedad, salvaguardando los lazos y la vida misma: No juguemos a ser malos. No me mates soy tu hermano. Libertad.

El empleo del nosotros articula un imperativo y una recomendación, mientras que la inscripción del yo, en relación con la segunda persona, se torna expositiva y ejemplar. Finalmente, el argumento se resume en una sola idea, en un concepto que propone distintos recorridos discursivos, pero que también tematiza una defensa y una convicción de libertad: elegir, actuar, compartir, crecer y sonreír.

\section{"Libertad para elegir y actuar. Para compartir con los}

demás. Libertad para los hombres.

Libertad de Libertad. Libertad para crecer en paz.

Para sonreírle a los demás. Libertad de pensamiento”.

La libertad universaliza distintas características que se ponen en la mesa como modo de repaso y de verificación para el futuro o para la demarcación de un horizonte. En este sentido, la práctica de la libertad puede vincularse con el hecho de seleccionar posibilidades, de accionar en determinados momentos, y de congraciarse con otros si el caso lo amerita. La apelación de la paz, por cierto, funciona como un espacio para recrearse y forjar nuevas perspectivas para pensar y apelar: libertad de pensamiento. Por 
esto mismo, el discurso de la lírica plantea un juego de dualidades entre el empleo del ustedes y del nosotros con el objeto de exponer una modalidad imperativa, de apreciaciones igualitarias y reflexivas:

"Tóquense las manos, nadie es tan distinto. No hay

nadie que no quiera amar. Saquéense los guantes, rompan las caretas. Toquémonos con libertad".

Así, la construcción discursiva de la lírica se orienta hacia la preservación de los lazos sociales y la idealización de la libertad con el objeto de apartar conflictividades y tensiones. La libertad, como temática y definición, es abordada en función de una representación canalizadora y pacificadora: en vínculo directo con las elecciones personales, las formas de comportarse y de compartir en sociedad.

\subsubsection{No somos los mismos}

"Manifestación de escépticos (So' lo ma' grande libertad)" Sueter (1984)

Sueter fue una banda que se fundó en 1981 y lanzó su primer disco homónimo en 1982. En la historiografía del rock argentino, la agrupación liderada por Miguel Zavaleta se posiciona como una banda entretenida y fresca que hacia el final de la dictadura contribuyó al desprejuicio de la sociedad, en clave de cultura rock. No obstante, el mismo Zavaleta ha señalado que el grupo se consagró por producir temáticas puntuales sobre la muerte, la opresión y los amores prohibidos: "Hay que reírse de las cosas, pero creo también que en medio de una cosa de fiesta pega más lo triste también. A nosotros nos nombraban como un grupo divertido, pero divertidos eran Los Twist, Los Abuelos de la Nada" (Conte, 1995: 31).

En este sentido, a partir de la puesta en rotación de canciones reconocidas como "Mamá planchame la camisa", "Lluvia de Gallinas" y el hit "Amanece en la ruta", Zavaleta sostenía una mirada analítica sobre la libertad individual y el libre pensamiento: "Siempre fui un poco reacio a seguir las normas de poder, y hay dos poderes visibles: el de los que tienen la manija y el poder de las cosas que se dicen y la gente las acepta porque sí. Hay palabras que en otras épocas no eran aglutinantes de poder y ahora sí lo son" (Guerrero, 1994: 140). 
Particularmente, la canción "Manifestación de escépticos (So' lo ma' grande libertad)" fue publicada en 1984 y se ubica como la octava pista del segundo y exitoso disco de la agrupación, titulado Lluvia de Gallinas. Este álbum permitió el reconocimiento popular de la banda y consagró a su líder y vocalista como una referencia importante para pensar la actualidad del rock argentino durante la década del 80.

En la lírica predomina la primera persona del singular y en segunda instancia se advierte la presencia de una segunda del plural, que incluye y sustenta una idea que recorre toda la discursividad de la canción: la libertad como alabanza y referencia para la paz. En virtud de ello, la libertad es nombrada metafóricamente como un monumento, que enlaza situaciones de paz y amor.

“Monumento, para el amor y la libertad.

Monumentos para el que te busque y te logre en paz".

La idea de monumento no se vincula únicamente con la libertad, sino también con una noción de reconocimiento que obtienen los sujetos que la pretenden, la buscan y la alcanzan en armonía y sin desbordes violentos. Ante esto, la libertad es contemplada como un logro devocional, como una esfinge a la que se le debe rendir pleitesía por su magnitud simbólica: Sos lo más grande, más grande del mundo. Sos lo más grande del...

La defensa de la libertad procura una generación de reflexiones y comprensiones sobre la complejidad de co-existir en un contexto de libertad, luego de situaciones de sufrimiento o de violencia. En este sentido, el enunciado que indica sos lo más grande implica una situación folclórica y cultural muy propia del fútbol en la que se destaca la grandilocuencia de un referente particular. La libertad, por consiguiente, se postula desde una categoría valorativa favorable, ya que la calificación de grande puede ser implicar algo máximo para el mundo y también puede interpelar universos más amplios, teniendo en cuenta la apelación de los tres puntos suspensivos: sos lo más grande del....

“Alguien no puede ver. Alguien no quiere creer.

Alguien no puede sentir que vos sos lo más grande del mundo: ‘Libertad!” 
En esta estrofa se advierte la presencia de una otredad (alguien) que se articula desde un desentendimiento y una incredulidad frente a la cuestión de la libertad. Esta última, postulada como persecución y consagración durante toda la lírica, también expone una tensión: la libertad aún no ha sido concretada de un modo general y todavía encuentra ciertas resistencias. Por esto mismo, la estrategia del hablante se expone de un modo determinante hacia el final con la redundancia, utilizando a la libertad como segunda persona (vos sos lo más grande del mundo) y como un grito de júbilo ¡Libertad!

A partir de este escenario de enunciación, el hablante se postula como un testigo que narra situaciones llamativas en aglomeraciones o en multitudes. La escena que se recrea es grotesca, pero contextualiza una situación de protesta y de vivencia en virtud de la defensa de la libertad.

\section{"Ahí va un dólar, lo persigue una manifestación y a ese hombre bueno le robaron hasta el pantalón (...) Ahí va Moria la persigue una manifestación y a ese hombre bueno le robaron hasta el camisón".}

En este sentido, la revalorización de la libertad comparte el escenario con la alusión contextual de una liberación económica y el destape sensual/sexual. En primer término, existe una referencia a la moneda extranjera del dólar que se dispara en el universo de las finanzas y que interpela a un sector manifestado, quienes en otras épocas perseguían la libertad a partir de la paz y ahora se encuentran seducidos por las divisas y los aspectos económicos.

En segundo orden, la figura de la actriz y vedette Moria Casán destaca la presencia de la seducción en esa manifestación, liberalizada por el dólar, pero también por los enlaces eróticos. Casán, como icono sexual de época, interpela a esa manifestación y la conmueve tanto como el dólar. A esta manifestación de escépticos, sin embargo, se la contempla desde la violencia y la urgencia. La escena es construida desde una instancia de premura y precipitación, puesto que se advierten robos y corridas vinculadas con una persecución de libertad monetaria (pretendidamente desfachatada) que confluye en una búsqueda libertaria impaciente. 
"Yo sé que la gente está cansada, ahora quiere

disfrutar. Ya no somos los mismos de hace algunos

unos años atrás. Sé de muchos que quieren pan,

pero no quieren circo".

El hablante intenta una explicación para comprender la actuación de la manifestación y la situación de violencia colectiva y simbólica. El locutor ensaya una respuesta que contempla las tres libertades puestas en acción: la persecución de una supuesta libertad económica (la búsqueda del dólar) se relaciona con el cansancio, con un estado de ahogo económico que la manifestación padeció en otros tiempos. Esa misma gente, aprehende los discursos de la sensualidad o el erotismo y necesita disfrutar. Por ello, el empleo del ahora subraya una situación deíctica temporal de un contexto determinado, de acción y búsqueda del goce.

Del mismo modo, la búsqueda de esa libertad, en términos del hablante, también se aprecia desde una coherencia y un estado de situación en el que se reconoce que el pasado ha sido conflictivo y dificultoso. La manifestación, que antes era narrada desde un lugar apartado, permite la inscripción del locutor dentro del discurso (ya no somos los mismos de hace algunos unos años atrás) y, a su vez, su perspectiva comentarista: sé de muchos que quieren pan, pero no quieren circo.

\subsubsection{Arrancar todo lo que me hiera}

"Una canción diferente"

Celeste Carballo (1985)

Esta canción fue editada en 1982 (al igual que "Ahora estoy en libertad") y publicada como la séptima pista del disco Me vuelvo cada día más loca. Es una de las piezas más conocidas del álbum por su musicalidad cadenciosa y su entonación romántica, profundizada por la participación del reconocido músico David Lebón, quien participa del estribillo y de los coros.

Carballo siempre se ha ocupado en destacar esta canción como una de las consagratorias de su carrera, no sólo por el éxito que obtuvo, sino por la lírica constructiva de género que propone y la propia historización que puede plantearle como autora: "Una canción diferente" es muy Grossa (...) A la libertad a veces cuesta decirla. Sobre todo, el contenido de la palabra. Es difícil de comprender. Yo creo que en la Argentina tenemos 
un gran ejercicio de este concepto de libertad, aunque lo vamos a ir mejorando con el tiempo, por supuesto" (Leikis, 2016).

La letra de "Una canción diferente" admite la presencia de una primera persona del singular que postula a una segunda como destinatario directo. En función de ello, la libertad es convocada desde la visión de la mujer, narrando una relación tortuosa de amor y un discurso que propone un posicionamiento de género.

\section{"Dame amor, dame tu corazón. Dame tiempo para respirar. Está muriéndose el sol, dame música para} crear, una nueva canción”.

En una primera instancia, se advierte un hablante demandante que reclama una entrega y una urgencia determinada a su interlocutor. Por esto mismo, desde la modalización imperativa manifiesta una vehemencia que parece comprimir y asfixiar (dame tiempo para respirar), pero también enmarca cierto tono trágico (dame tu corazón). Dicho apresuramiento en el pedido se habilita a partir de la enunciación de un contexto adverso que se construye a partir de la figura del ocaso del día (está muriéndose el sol) y que se sostiene también en función de la creación, la musicalidad de la vida y la nueva composición: Se abre despacio en el medio de la jungla, son nuestras voces que se escuchan juntas.

En este sentido, se postula un escenario nocivo, en el que la metáfora de la jungla sirve para comprender un rasgo poético de unidad entre los interlocutores y proponer un distanciamiento y una defensa de las libertades individuales. La llamada jungla parece ser el escenario urbano que, en función de las aglomeraciones y las propias relaciones, puede perjudicar los entornos. No obstante, la colaboración se aprecia como una unidad ante los avatares de la vida cotidiana. Por ende, el discurso de unicidad y de asistencia mutua se vincula con el reclamo inicial y con la crítica al contexto que resulta abrasivo y perjudicial para el hablante.

"Me revolqué por la realidad y ahora estoy destruida, necesito tu amor. Ya no me aguanto una mentira más”.

Esto último enunciado permite que el hablante enlace su condición de mujer como motivo para persistir en la lucha y como modo de llevar un accionar de paz en una 
contextualización desfavorable: me revolqué por la realidad y ahora estoy destruida. Simultáneamente, reclama una necesidad de amor como principio para defender una libertad (necesito tu amor) y destacar una situación de hastío (ya no me aguanto una mentira más). En consecuencia, el empleo de los adverbios ahora y ya recuperan la urgencia diagramada inicialmente y se refuerza a partir de la construcción de un pasado inconveniente (me revolqué en la realidad).

Así, el hablante no sólo anuncia su lugar como mujer en el discurso, sino también se inscribe en la enunciación, exponiendo su espacio y abriéndose a la disputa con un colectivo que es destacado a partir de la construcción enunciativa que refiere a todo el mundo.

\footnotetext{
"Yo con mi cuerpo de mujer voy a dar la verdad. Si todo el mundo vive haciéndonos la guerra, yo necesito que me des tu paz".
}

La segunda persona cobra importancia porque actúa como sostén para el yo de la lírica y funciona como un referente que brinda atención, cariño y amor (necesito que me des tu paz). La mujer se consagra entonces como un símbolo de verdad, frente a la falsedad (ya no me aguanto una mentira más) que parece reinar en todo el mundo y que ataca las libertades a partir de una puesta en común belicosa y agresiva. No obstante ello, la libertad resulta una consecuencia de la propia actuación y de la individualidad de ese hablante en condición de mujer: necesito arrancar todo lo que me hiera. Necesito amor, necesito más, más libertad.

\title{
6.2.6. Salí a la calle
}

"Nada me detiene"

La torre (1986)

\begin{abstract}
"Nada me detiene" es la canción que da inicio al cuarto disco de La Torre: Presas de caza, editado en 1986. El álbum es uno de los más recordados de la banda porque contiene los clásicos "Estamos en acción” y "Siluetas de sal”. En lo que concierne a la lírica en cuestión se advierte la presencia de una primera persona del singular que desde el género femenino, construye una situación discursiva de reflexión y de ofensiva. El
\end{abstract}


hablante presenta así enunciados en defensa de su libertad individual y ante los ataques de una tercera persona del plural que no proviene de un colectivo definido.

En función de ello, el yo de la lírica expone un escenario de reflexión, que da comienzo a su lucha desde el pensamiento y su estado compungido: sola y triste en la mañana, tengo que prender la luz. Desnuda, roja mi cama, tengo que ver la razón.

El empleo de cargas valorativas presenta una situación de indefensión inicial, que subraya soledad, oscuridad y tristeza (sola y triste). Del mismo modo, la desnudez se aprecia desde una subjetividad femenina que expone cierto despojo (desnuda, roja mi cama) y también una toma de conciencia sobre lo que vivencia y perjudica (tengo que ver la razón):

\section{"Sali a la calle decidida a cualquier cosa, mientras los buitres no dejaban de volar. Toda esa gente que nos mira enloquecida, no entiende la libertad".}

El encuentro con el exterior (la calle o la ciudad) y la escapatoria del universo personal, permite que el hablante construya una articulación defensiva que ya no se manifiesta de un modo individual (sali a la calle), sino desde una constancia plural (toda esa gente nos mira). La preservación de la libertad parece ser primordial en una situación agresiva, en la que un colectivo nocivo pretende provocar violaciones a la intimidad y el goce persona (los buitres no dejaban de volar). Esta metáfora que recrea la violencia y la paciencia de ataque de un grupo contrario (toda esa gente), permite incluir a otro colectivo en la protección de la libertad, puesto que la asignación del nosotros sirve para argumentar un estado de incomprensión.

\section{"Pensando caminar un rato, tú verás a la ciudad. \\ Mientras Buenos Aires duerme, mi cuerpo despierto está”.}

En este sentido, el tránsito del hablante se encuentra en estado de alerta, con la corporalidad dispuesta para la defensa y una puesta en acción deliberada o circundante (mi cuerpo despierto está). Se plantea así un enfrentamiento contra los denominados buitres de madrugada, que recorren provocativamente una ciudad expuesta (Buenos 
Aires duerme) y que pueden subyugar cualquier intento de liberación (no entienden la libertad).

"Porque soy mucho más que un par de lindas piernas.

Corazón total, si es el momento de estar alerta".

El locutor, en este caso, construye una perspectiva femenina que refuerza el estado de defensiva y resalta la autonomía de su cuerpo y su cotidianeidad en relación con el género. Se expone así una situación de entrega y compromiso que da cuenta de un estado de libertad (corazón total) en un marco de atención.

Al respecto, resulta interesante señalar el desplazamiento que realiza el yo de la lírica en el enunciado que oficia de estribillo, puesto que se inscribe en el discurso desde la primera persona, pero también articula la enunciación en relación con el plural, argumentando una imposibilidad de detención en la defensa de la libertad: nada me detiene, nada me detiene, nada me detiene, porque nada, nada nos puede parar.

La supuesta detención propuesta por los llamados buitres y esa gente que nos mira no atenta únicamente contra el hablante y su individualidad, sino contra un colectivo, como se mencionó anteriormente. De la misma manera, el acto de interrupción no es tomado en cuenta por el hablante por una razón puntual e imperante: no existe acontecimiento o sujeto determinado que pueda contener la realización y la consecución de la libertad.

\subsubsection{Un rock and roll que me sacuda la cabeza}

"Nunca podrás sacarme mi amor" Fito Páez (1986)

Fito Páez es uno de los artistas más importantes del rock argentino por su influencia en la música hispanoamericana y su trayectoria en el ámbito de la canción popular. Fue integrante de la mencionada trova rosarina que acompañaba a Juan Carlos Baglietto, trabajó como músico invitado en la banda de Charly García y participó en numerosas colaboraciones junto a destacados artistas internacionales.

Tras su prominente aparición en la escena musical, su esperado debut solista se llevó acabo en 1984, bajo el nombre Del 63 y a partir de allí publicó más de veinte álbumes de estudio. Entre los más celebrados, se encuentra Giros, editado en 1985 y Ciudad de 
pobres corazones, lanzado en 1987, dos discos que proponen un lirismo muy profundo en relación con las transformaciones que la democracia produjo en el país.

En este sentido, Páez se convirtió en uno de los artistas más considerados por la crítica especializada. Se lo exponía como la demostración más palpable de la renovación del rock argentino y de la vigencia del género como actitud, idiosincrasia y reflexión. Al respecto, la revista Canta-rock señalaba: “Cuando empiezan las dudas sobre si el género ya se vendió al sistema comercial plastificador (...) acercate a escuchar a este pibe que tiene casi la misma edad que el rock y viene a ofrecer su corazón con la misma pasión que los más grandes momentos de esta historia de música sincera" (1985: 66).

La canción "Nunca podrás sacarme mi amor" es la tercera pista del EP Maxi Sencillo y Cassette Corazón Clandestino que contiene cuatro temas y fue publicado en 1986. Este trabajo tiene la particularidad de ser el único de la discografía de Páez que no tiene edición en $\mathrm{CD}$. Si bien es un álbum inhallable y considerado una reliquia para los seguidores del músico rosarino, tres de los cuatro temas que lo integran aparecen en recopilaciones posteriores.

Particularmente, en "Nunca podrás sacarme mi amor" se manifiesta una toma de posición y una defensa del amor y de la libertad de amar como posibilidad de cambio y de obstinación. Por esto mismo, la lírica presenta una primera persona que lucha por imponer su idea de libertad ante los actos de interrupción y obstrucción de las autonomías individuales. En este aspecto, el locutor se dirige hacia una segunda persona que oficia de destinatario opuesto y alejado. Así, el yo de la lírica construye una consideración de la libertad, vinculada con el amor de hacer, crear, creer y vivir en sociedad, demostrando entonces una tozudez hacia las otredades que intentan detener su consagración:

\section{"Puedes decirme que si, puedes decirme que no. \\ Pero nunca podrás sacarme mi amor. \\ Puedes quemarme los pies, puedes dejarme sin voz. \\ Pero nunca podrás sacarme mi amor”.}

La conservación del amor, pese a las embestidas y los ataques, se presenta como síntoma de fortaleza para el hablante porque permite una preservación de ideales (De la Puente y Quintana, 1996: 214). Esa segunda persona, opuesta a la primera, actúa en vínculo directo con las imposiciones (puedes quemarme los pies) y las acciones 
silenciadores que continuaban manifestándose en un contexto de reconstrucción democrática (puedes dejarme sin voz).

Por esta razón, el yo de la lírica pone en juego un leitmotiv articulador y generalizador que tematiza su opción apasionada e infaltable de libertad: nunca podrán/podrás sacarme mi amor. A partir de esta tendencia, se reitera una posición de vida y se ofrece respuestas hacia aquellos que parecen contrariar o criticar los modos de crear un universo cotidiano.

\footnotetext{
"Y si es folklore o si no, y si es Urano o Plutón (...)

Y pueden verte feliz cuando acá todo es un bajón (...)

Pueden vender un país y estar del lado de Dios.

Pero nunca podrán sacarme mi amor (...)

Puedes echarme de aqui por no pensar como vos, pero nunca podrán sacarme mi amor”.
}

En este fragmento, la concepción de la cultura rock cobra una dimensión relevante porque destaca la importancia que tiene en relación con el vínculo libertario. La diferencia radica en torno a la construcción de una tercera persona que intenta o pretende modificar el funcionamiento de la cultura y que puede poner en circulación discursos determinados. En función de ello, pueden generarse tópicos que colocan en tensión la idea de la libertad y permiten articular opciones heterogéneas: es posible hablar de una liberación desde el folclore y no a partir del rock; criticar los modos de poner en ejercicio la diversión personal; considerar nuevas formas de entender el planeta y sus formas (urano o plutón); sostener descripciones sobre la juventud y sus situaciones de felicidad; destruir la riqueza de un país o de un nación; y por último esconder las intenciones al amparo de la iglesia o la religión. No obstante ello, la estrategia consiste en revalorizar el amor por la música como un modo de persistencia que identifica a la cultura rock en su constante búsqueda y defensa de su libertad:

"Ni un analista, ni un doctor, ni un cura (...) Ni

(Marcelo) Stubrin, ni el gobernador te solucionan los

problemas. La gente busca una razón, yo estoy

buscando una canción que me sacuda la cabeza (...)

un rock \& roll que me sacuda la cabeza”. 
Este enunciado se construye a partir del empleo de una conjunción copulativa (ni), que en este caso coordina de manera aditiva frases que denotan una negación principal, en relación con la solución de problemas de existencia: Ni un analista, ni un doctor, ni un cura. Las tres opciones que se advierten refieren a los distintos refugios en los que se buscan consideraciones para la resolución de inconvenientes: la psicología, la medicina y al religión. Del mismo modo, la negación también remite a la política y la figura de personas públicas: ni Stubrin, ni el gobernador.

En este sentido, la primera enunciación destaca la presencia representativa de Marcelo Stubrin, uno de los fundadores de la Junta Coordinadora Nacional, conocida simplemente como La Coordinadora, que acompañó a Raúl Alfonsín en las políticas vinculadas con los jóvenes. La inclusión del apellido Stubrin en la lírica no parece azarosa porque lo postula como una figura importante de la política, ya que, como funcionario de la UCR y participante del universo democrático de la época, ocupa un lugar primordial en el universo social (Ferrari y Herrera, 1987:215) ${ }^{48}$.

El estribillo de la lírica, asimismo, también refuerza una idea de defensa hacia la cultura rock y la incluye en un escenario reflexivo, pero también argumentativo de protección libertaria. El hablante demuestra que no necesita explicaciones ni tampoco persigue la clausura de problemas en sujetos que cree defectuosos. Lo que lo desvive, lo conmueve o lo moviliza es la búsqueda dentro de la cultura rock, porque allí aguardan sus respuestas y sus soluciones (yo estoy buscando un rock \& roll que me sacuda la cabeza). En este sentido, el hablante parece reconocer que el rock, como género, actitud y vivencia, se encuentra sumergido en un mercado cultural que no ofrece una salvación permanente, no obstante, puede lograr conmover y movilizar las conciencias.

\footnotetext{
${ }^{48}$ Vale señalar que Páez no tuvo una buena relación con el radicalismo por dos cuestiones imperantes: por un lado, durante el desarrollo de la década del 80 se calificó como peronista en distintas entrevistas y, por otra parte, desconfiaba de la cercanía política dispuesta por La Coordinadora: "Ellos están del otro lado. Nunca se van a sentar a comer con vos (...) La JR (Juventud Radical) quiere invitar a la gente a hacer rock, pero (el presidente de la JR, Andrés) Delich nunca va a estar conmigo, con Charly o con Sumo" (Guerrero, 1994: 150).
} 


\subsubsection{Somos más hermanos que antes}

"Yo no me sentaría en tu mesa" Los Fabulosos Cadillacs (1987)

Los Fabulosos Cadillacs es una agrupación que se fundó en 1985 y editó su disco debut Bares y Fondas en 1986. Si bien es uno de los grupos argentinos más representativos del ska, ha desarrollado sonoridades con ritmos latinos, y sonidos de rock, pop o reggae durante el desarrollo de su extensa carrera. A lo largo de la segunda mitad de la década del 80 se convirtieron en una referencia underground insoslayable dentro del rock argentino, sobre todo a partir de la edición del segundo disco de la banda, titulado Yo te avisé, producido por Andrés Calamaro y publicado en 1987. En términos de la revista Rock and Pop, este disco atrajo nuevos seguidores a partir de una veta prolija de skapop "que no contenía uno, sino casi media docena de hits" (1989: 56).

La canción "Yo no me sentaría en tu mesa" se encuentra ubicada como la sexta pista de dicho álbum y su elaboración tiene un punto de referencia ineludible vinculado con el altercado que tuvo la banda con funcionarios de la UCR luego del evento "La juventud radical va con vos". Al respecto, el cantante de la banda, "Vicentico" Fernández Capello, tomó distancia del gobierno alfonsinista y se mantuvo crítico con el gobierno, negándose a compartir espacio con el diputado nacional Jesús Rodríguez, aduciendo que no se sentaría en la mesa de quien firmó la ley de Obediencia Debida (Provéndola, 2015: 152).

Siguiendo esta línea, desde una óptica oficial confirmada por la banda, se reconoce que la canción fue compuesta luego de que el grupo se negara a participar en la conferencia de prensa de un festival al que habían sido invitados por la Juventud Radical. En efecto, "Yo no me sentaría en tu mesa" marca una diferencia en la relación entre la política y el discurso de la lírica del rock argentino de la época, debido a que el discurso postula una vehiculización conflictiva y tirante con el gobierno de turno (Blanco y Scaricaciottoli, 2014: 146).

La enunciación articulada en la lírica construye un canto de hermandad que apela a un grito o a una vociferación de tribuna. Por ello, la estrategia discursiva manifiesta la presencia de un colectivo que defiende una instancia de libertad y de estado lúdico ante la posibilidad de avasallamiento y de críticas. 
Por esta razón, la estructura de la lírica establece una demarcación entre un colectivo interpelador y disruptivo (ellos/vos), y un nosotros que incluye a un tribu o a una filiación (nosotros).

\section{"Por más que quieran sacarnos de nuestro lugar. \\ $Y$ pienses que somos solo un puñado de idiotas. \\ No podrás quitarnos lo que hicimos ya. \\ Ahora somos más hermanos que antes".}

En este aspecto, el colectivo que enuncia delimita una zona de territorio, quizás cultural, en la que se expone una actitud obcecada e intransigente (por más que quieran sacarnos, no podrás quitarnos). También, el empleo del nosotros contrapone los enunciados adversos, que especulan y encasillan, reforzando una idea de hermandad que se precisa aún más desde el adverbio: ahora somos más hermanos que antes.

En función de esta unión voluntaria y primordial para tomar un rol activo desde una perspectiva juvenil, el hablante continúa la enunciación desde la primera persona del plural y se pronuncia contra una individualidad que parece esconder un colectivo cercenador y castrador:

’Ya no podrás mirarnos a los ojos más.

Nosotros somos amigos, vos que solo estás.

Por más que quieras callar toda nuestra voz.

Nunca podrán callar esta canción".

El discurso de la lírica prosigue un camino de confirmación y de reafirmación del terreno cultural del enunciador, destacando así su ámbito de libertad y de puesta en acción de la práctica (mirá mis pies bailando, voy a vestirme de traje, voy a saltar toda la noche). El destinatario continúa destacándose a partir de una individualidad que se contrapone a los quehaceres del hablante, y se aprecia como una antítesis de este ser discursivo. Por consiguiente, el locutor lo utiliza como referencia para obtener un lugar de definición en virtud del baile, la vestimenta y las actitudes intempestivas que podrían molestar a las estructuras tradicionales de la sociedad (saltar, silbar) 
"Y si después no creés lo que te estoy diciendo, mirá mis pies bailando al son de este ritmo. Voy a vestirme de traje aunque me vea mal. Voy a saltar toda la noche sin parar de silbar. Está lloviendo, pero yo no me voy a mojar. Mis amigos me cubren cuando voy a llorar. Por más que quieras callar toda nuestra voz, Nunca podrán callar esta canción”.

En relación con la voluntad de unión y la confianza en la identidad de grupo, la lírica transita nociones solidarias entre los anteriormente denominados hermanos, que en esta instancia se enuncia en función de la amistad (mis amigos). El locutor retorna a la primera persona, destacando su lugar en la situación de grupo, en detrimento de las cuestiones individuales presentadas por su interlocutor. Este aspecto, le permite finalizar la enunciación con una estrategia que oficia como mensaje enfatizado y con intenciones legítimas.

\subsubsection{Contentos de estar vivos}

"Salgamos a la calle" Man Ray (1988)

Man Ray es un dúo formado en 1987 por dos músicos que han participado activamente durante la década del 80: la fotógrafa y cantante Hilda Lizarazu y el guitarrista y productor Tito Losavio. Ambos artistas fueron integrantes $\mathrm{y} / \mathrm{o}$ colaboradores de distintos grupos y/o solistas de rock argentino de los 80: Los Twist, Andrés Calamaro, Suéter o Charly García, entre otros.

El disco debut, editado en 1988, fue producido por Andrés Calamaro y llevó el mismo título de la banda Man Ray, bautizado así en homenaje al provocador fotógrafo surrealista estadounidense.

La canción "Salgamos a la calle" es la décima pista de un álbum que tuvo una rotación moderada en las radios del país, pero que contiene dos canciones recordadas en el ambiente del rock argentino de la época: "Extraño ser", cover de Sueter y "Señal que te he perdido", compuesta por Calamaro.

Particularmente, en la canción predomina una primera persona del singular que enumera preferencias y quehaceres para llevar a cabo sus actos libertarios. En este aspecto, el 
grito, el canto y el baile se convierten en acciones que proponen una defensa del ser libre y, desde ya, las propias elecciones de vida.

"Prefiero gritar practicando una melodía.

Prefiero cantar antes que verla a mi tía.

Prefiero bailar desnuda en una pieza".

Como se mencionó, esta disposición enunciativa propuesta por el hablante expone decisiones, compromisos y preferencias que verbalizan acciones idealizadas: gritar, cantar y bailar. Al respecto, el hablante se defiende de las acusaciones que podrían perpetrar otro $\mathrm{u}$ otros en un contexto adverso determinado y en relación con sus voluntades: "Tal vez está mal, pero no es ninguna rareza"

En función de este último enunciado, se advierte una situación polifónica de respuesta que expone una consideración negativa sobre los actos libres que dispensa el yo de la lírica. También se articulan dos juicios de valor que contraen actos respectivos: la búsqueda de la liberación puede considerarse, en un ámbito conservador y tradicional, como una mala decisión o un hábito desfachatado. Así, el hablante le brinda algún tipo de entidad al remarcar una modalidad lógica que restringe la seguridad (tal vez); se aprecia, asimismo, la presencia de una voz que destaca estas voluntades desde el extrañamiento o la rareza, contemplando las acciones como situaciones inhabituales (pero no es ninguna rareza).

"Los días que vendrán prefiero disfrutar.

El tiempo no está mal, lo veo hoy mismo".

En esta estrofa, el hablante destaca una nueva preferencia, anunciando una situación próxima en la que, quizás, la adversidad podría apoderarse de las apreciaciones. Por ello mismo, elige el regocijo y toma la libertad de disfrutar y comprender desde los aspectos positivos el contexto, en respuesta a voces que auguran un destino de peligro: salgamos a la calle contentos de estar vivos. Si no que otro motivo te puede ya salvar.

El empleo del nosotros sirve para reforzar las características positivas de la enunciación, defendiendo las libertades de actuar en la calle y presentarse en el espacio público como protagonistas. No obstante ello, el hablante no se aparta de la idea latente de las complejidades en el contexto, anunciando que el disfrute se torna un arma de defensa 
libertaria y un impulso más que elocuente. Por esta razón, se dirige directamente a una segunda persona que, tal vez, se encuentra dubitativa o en plan de reclusión, que, de acuerdo a lo que se advierte (me quedo sola), comprende las directivas, considerando a la libertad como un hecho de descubrimiento: te queda por buscar.

\subsection{Consideraciones parciales}

\section{Una estrategia de defensa}

Las líricas abordadas anteriormente remarcan una labor activa de la defensa de la libertad, en virtud de una idea de movimiento, actuación, realización y participación individual y colectiva. A partir de ello, se indica una renovación que propone una distinción y una reconfiguración de las prácticas en sociedad.

Los discursos esgrimidos en las letras permiten diagramar un escenario de expectativas e incertidumbres manifiestas que presentan enunciaciones simbólicas y explicitan una construcción de libertad narrada desde un enfoque positivo. De esta manera, la libertad es representada como el vínculo directo de las elecciones personales, individuales, en un principio, aunque también plurales en otras instancias.

Las líricas refuerzan una idea de defensa muy propia de la cultura rock y contienen así un argumento reflexivo que procura defender las autonomías. El espacio del rock es comprendido como una experiencia sumergida en un mercado cultural que, pese a las tensiones, admite la conmoción y la movilización de los estamentos de la sociedad.

Precisamente, el empleo de la segunda persona del plural en algunas líricas incluye y sustenta una idea que recorre la discursividad articulada en la canción: la libertad entendida como referencia para defender un territorio y desarrollar un logro fundamental y pasional. Por tanto, la defensa de la libertad se encuentra enmarcada desde diferentes escenarios: 1) la propia poética de la vida como lugar sincero de preservación emancipatoria, 2) los espacios públicos como sitio aprehensión de prácticas y la cotidianeidad como ámbito para poner en juego los diferentes modos del ser libre, 3) el pensamiento y la definición política como vehículo de reconocimiento. En consecuencia, se aprecia un discurso de libertad relacionada con la afectividad y la noción sentimental que defiende la articulación de lo libre y propone una búsqueda de movimiento ("Ir a más") y una voluntad de provocación a partir del romance ("Una 
canción diferente") y la cotidianeidad como marco de independencia ("Yo soy tu bandera").

En relación con las consideraciones sobre la libertad y su consiguiente reflexión de defensa en el espacio público, las líricas refuerzan la contraposición hacia el colectivo ellos. En este sentido, se manifiesta una estrategia enunciativa que se opone al autoritarismo ("Nada me detiene") y exige una participación activa de las juventudes y/o los seguidores de la cultura rock ("Manifestación de escépticos", "Salgamos a la calle").

Siguiendo esta línea, las letras también plantean una toma de posición en relación con el deber ser de los jóvenes en un marco de transición y defensa de la democracia ("Nunca podrás sacarme mi amor”). Del mismo modo, se subraya una preservación de la libertad a partir de críticas y sátiras que colocan en crisis las consideraciones de sectores tradicionales o convencionales ("Yo no me sentaría en tu mesa"). No obstante, también es posible advertir una promulgación de una libertad apartada de conflictividades y resistencias que exponen intenciones de vivir y repelen un pasado de ataduras y prohibiciones ("Libertad de pensamiento"). 


\section{Capítulo VII}

\section{Una política de frivolidad: la construcción de la libertad en la cotidianeidad}

\subsection{Una temática corporal}

Como se ha mencionado previamente, durante el período 1982-1989 las letras de rockpop argentino intentaron deconstruir los postulados sobre los que se basaba la cultura rock desde sus inicios. Así cultivaron una representación directa y una iniciativa política sobre lo social desde una instancia discursiva de entretenimiento o diversión. A partir de lo social, se abrieron dos frentes notables que propusieron tácticas y estrategias enunciativas distintivas en torno a la situación de lo bailable y lo contracultural: se postulaba a la corporalidad como lugar de dominio libertario, y se buscaba un tenor irónico y parodiado en el ámbito cotidiano.

La temática de la diversión y la alegría, como respuesta y reacción contra el pasado represivo y su actualización en democracia (policía, servicios de inteligencia de civil, mano de obra desocupada de los militares) se vivió como una acción política. El cuerpo se configuraba como herramienta de insubordinación al abrir una tensión entre los regímenes disciplinarios-normalizadores y el propio quehacer libertario.

Las nociones y las puestas en ejercicio del baile acompañaron de un modo significativo los cambios de sensibilidad que tuvieron lugar en la sociedad post-Malvinas y ampararon momentos de participación y/o demandas populares. El advenimiento democrático reconfiguró el espacio que el rock argentino tenía en la cultura oficial del país y resignificó las prácticas y las experiencias de sus seguidores. Ante esto, el período que se inició a partir de 1982 produjo una auténtica revalorización del baile en el marco de la cultura rock y le brindó una popularidad inusitada al movimiento, entendiéndolo como un elemento que representaba el espíritu general de los jóvenes y de buena parte de la sociedad.

Conviene entonces pensar este cuadro de transformación e intervención social a partir de las propuestas que diversos grupos/solistas/músicos de la cultura rock retomaron en conjunto. Por esta razón, el capítulo actual reflexiona y aborda la escena bailable que se puso en juego desde el discurso lírico del rock argentino a partir del retorno democrático. Es decir que, desde sus posturas artísticas, estéticas y líricas, los artistas 
comprendieron al acontecimiento-baile como testigo de transformación y como una práctica que se reinsertó en el mundo del rock con dos intenciones esenciales: 1) acompañar los desafíos en pos de la defensa de la libertad; 2) consolidar los procesos democráticos.

Cabe señalar que en otras épocas el imaginario del rock argentino condenaba el espacio de la disco y lo asociaba con la complacencia y la ausencia de compromiso. Sin embargo, fue durante la década del 60 que el rock comenzó a generar búsquedas experimentales en sus letras, desplazando así al concepto baile-entretenimiento por otro que combinaba el mensaje con la introversión (Correa, 2002).

La llegada de la democracia logró lo que antes se pensaba imposible y que sólo había sido empleado durante la década del 50: la alianza entre el rock, el baile y la celebración del cuerpo en ámbitos marginales, primero, y en discotecas, boliches y recitales, luego. De hecho, en los conciertos anti-convencionales se trataba de encontrar formas íntimas de libertad, a fin de desatemorizar las sensaciones de los jóvenes y desacralizar los cuerpos en movimiento conducidos por el "deseo del juego" que se oponía al orden de concentración militar:

Durante los 80 se reactivó la tradición sesentista de actuar en las discotecas. Por un lado era el trabajo más rentable y además según los artistas, "más desafiante". A partir de 1985 el Parakultural, Mediomundo Varieté y Cemento como espacios multi eventos, y el Centro Cultural Rojas como la única institución estatal, las discos de capital y de la provincia. Palladium, Crash, New York City, Pinar de Rocha funcionan en el circuito de la madrugada, después del Parakultural (...) Mas que "instituciones" estos lugares eran "espacios", los cuales -a diferencia del teatro- eran lugares de experimentación creados con otros propósitos (Garrote, 2006).

La disposición general se orientó hacia la diversión, el regocijo y la puesta en acción del placer. En este sentido, el simbolismo del baile incrementó las virtudes de la democracia política, activa y cultural en relación con la transición a un nuevo estado de derechos y libertades. El término del autoritarismo se encontró así en las antípodas de la liberalización bailable: el rock-pop se afianzó con la idea del baile y buscó posicionarse en contra del pasado Estado autoritario, las prohibiciones militares, las restricciones personalistas y las sociedades conservadoras. 


\subsubsection{Postura y baile}

La experiencia democrática permitió nuclear dos instancias: la convivencia con las situaciones críticas y terroríficas provocadas por la dictadura cívico militar y la exaltación de los derechos humanos como discurso de resistencia, sensibilidad y justicia. Ambas líneas influyeron fuertemente en el desarrollo de la ciudadanía a partir de 1983. Se admitió la existencia de un estado interventor que aún se vinculaba con conductas autoritarias (referidas a las interposiciones golpistas y rupturistas de las sucesiva dictaduras en la historia argentina), pero que, asimismo, destacaba búsquedas de justicia en virtud de las nuevas pretensiones paradigmáticas de las nociones democráticas.

La cultura rock local, desde su orientación masiva, discursiva y práctica concibió a la democracia como un proceso de disputa y construcción permanentemente. Así, el espacio del baile se configuró como un lugar de lucha por la democracia, que colocó a prueba la validez de las normas extendiendo sus límites y ampliando sus posibilidades (se conquistaron derechos irrenunciables y se construyeron áreas de ciudadanía crítica). De acuerdo con ello, la formalización institucional de la democracia argentina permitió el planteo de la tensión desde una dimensión formal y sustantiva: por un lado, se asoció la norma, los procedimientos y las reglas necesarias en pos de un espacio de construcción política y cultural. Por otro, se vinculó la acción, la transformación y la lucha en referencia a los sujetos y su lugar en entramado social.

La consideración del baile como concepto y eje particular del divertimento acompañó de un modo significativo los cambios de sensibilidad que tuvieron lugar en la sociedad argentina post-Malvinas, en momentos de participación y peticiones populares. El alcance democrático logró la reconciliación del rock con el baile y cierta idea del baile como celebración del cuerpo.

Como se destacó anteriormente, hacia finales de la década del 60 y durante la totalidad de la del 70, el imaginario del rock argentino no pensaba el baile como una actividad elemental para la vida social de las personas. Por el contrario, lo concebía como un elemento opuesto a la autenticidad reflexiva de la cultura rock y lo condenaba por su complacencia y la ausencia de compromiso social o humano que supuestamente pregonaba. De este modo, los más tradicionalistas enfrentaron a la música disco tomando como punto de controversia la figura del actor John Travolta, protagonista emblema del film “Fiebre de sábado por la noche” (estrenado el 20 de julio de 1978). 
El fenómeno bailable de Travolta y la música disco en sí fueron vistos como algo desagradable y contrario a la estética rockera. El espacio de la discoteca enarbolaba el desplazamiento del centro del ceremonial joven al recital y no permitía la formación de un sujeto colectivo construido desde la cultura rock: "La tapa del número de septiembre de Expreso Imaginario trajo un retrato fotográfico de Travolta...con un tomate estallando muy cerca de su sonrisa. El tomate era el revés del aplauso, en una larga tradición teatral" (Pujol, 2005: 190).

\subsubsection{Baile y entretenimiento}

La década del 50 se constituyó como una etapa de fusión entre la cultura rock y la concepción del baile a partir de una noción de rebeldía y desobediencia. No obstante, en la década del 60, el rock comenzó a generar mensajes y búsquedas experimentales en sus letras, desplazando así al concepto baile-entretenimiento que había logrado cultivar en otros tiempos. Pese a ello, casi quince años después, y a pocos meses de la retirada militar, muchos grupos del rock argentino comenzaron a retomar la propuesta primigenia e ingresaron en el mundo de las discotecas re-significando viejas costumbres que certificaba con el rótulo rock-pop (Correa, 2002: 49).

Al respecto, Eduardo Berti señala que hasta el conflicto de Malvinas, el rock argentino había sido fundamentalmente no-bailable, ya que los recitales eran concebidos como una estética de misa: la gente, contenida por la represión externa, escuchaba sentada, y en reverencia (1994: 34). De hecho, tras la guerra de Malvinas, el rock local pasó a ocupar lugares que antes eran considerados espacios "enemigo": las radios, en primer lugar, la televisión, en segundo lugar (aunque más lentamente), y las discotecas, por último. De pronto el rock argentino podía bailarse en las discotecas, algo impensable un año antes, en 1981, pese a que la música iba tendiendo poco a poco a lo bailable en consonancia con lo que se estaba haciendo en el mundo entero (Secul Giusti y Rodríguez Lemos, 2011: 111).

Si bien en los primeros años de la transición democrática la relación entre el rock argentino y la cultura del disco mostraba intenciones de afianzarse, no todos los integrantes de la cultura rock se mostraban de acuerdo. Los más conservadores esgrimían epítetos contra los nuevos exponentes del rock que incitaban al baile y peyorativamente los tildaban de "divertidos", frívolos", bailables", "plásticos". Sin embargo, los denominados "herejes del rock" reivindicaban su capacidad de adecuarse a 
los nuevos tiempos: se asumían como "modernos", "nueavoleros", "hijos del pop" y se mostraban felices de que su música se difundiera en las discotecas (Pujol, 1999: 326). Siguiendo esta consideración, tanto Virus como Charly García (en plan solista), Los Twist, Los Abuelos de la Nada y Soda Stereo fueron los grupos que más desafiaron las estructuras tradicionales del rock argentino (Pujol, 1999: 326).

A partir de la invitación, la alusión discursiva y la intención bailable, los exponentes del rock argentino trazaron aullidos desgarrados, protestas que criticaban la falsedad social y la inauténtica armonía en tiempos posdictatoriales: el rock, desde la parodia, la exageración y la apariencia anodina interpeló a los jóvenes y la mayoría de las esferas o distinciones trans-generacionales.

La propuesta de la cultura rock giró en torno a la revalorización de la civilidad y el estado de derecho, pero también se opuso a las injusticias, los autoritarismos, las opresiones y las formas residuales del terrorismo de estado (discursos estigmatizantes, imperativos, absolutistas y prejuiciosos). El baile, como espacio igualitario y liberador, se configuró como un espacio de transformación que albergó distintas disidencias. A partir de las prácticas, el rock forjó ciertas luchas contra-hegemónicas, tácticas tácitas y/o expuestas, así como construcción de identidades, estrategias discursivas y producciones de sentido en vínculo directo con las líricas de los artistas de rock argentino:

\footnotetext{
Reírse, bailar, jugar, crear en la dispersión y divertirse desde la banalidad estaba presente en la formación actoral a través del clown y la acrobacia (...) Paralelamente el ritmo del pop y el ambiente de la disco profundizan un reconocimiento de la validación de la experiencia de relaciones efímeras o casuales, pero no por ellos menos significativas. Entre el público y los actores de estos shows al compartir deseos, códigos, represiones y marginalidades se establecían momentos de entendimiento inter-subjetivos tal como se establece en una "comunidad espontánea" (Garrote, 2006).
}

En su dimensión ideal, discursiva e influyente, el baile desató polémicas y repercusiones conservadoras dentro del propio seno del rock argentino (tradicionalmente meditativo y solemne en algunos aspectos), no sólo por la osadía de invitar al baile que tenían los artistas, sino por la propuesta de divertirse a partir del desenfado y el rechazo al horror. 


\subsubsection{La política del humor}

La proliferación de discursos cotidianos y fragmentarios en las líricas del rock argentino de la década del 80 permitió alcanzar exploraciones identitarias, relacionadas en ciertos casos con la sexualidad y el erotismo o los abordajes pasatistas y pretendidamente posmodernos. Del mismo modo, el empleo del humor se advirtió como una estrategia discursiva de articulación y retroalimentación de la protesta o la manifestación irónica. Exceptuando algunas manifestaciones de La Pesada del Rock and Roll y Pedro y Pablo en los inicios de la década del 70 o de Serú Girán a principios de la del 80, el humor se constituyó como un rótulo novedoso y práctico durante la transición democrática. Por tanto, comenzaron a apreciarse temáticas distintivas que implicaban tabúes $\mathrm{y}$ prohibiciones a partir de las instancias paródicas. De esta manera, emergieron tópicos antes silenciados como la homosexualidad, la droga o el terrorismo de estado, articulados en función de una estrategia discursiva irónica y sarcástica. "Camuflados detrás de textos que a primera vista (o mejor, a primera audición) podrían llegar a ser acusados de pasatistas, teniendo un trasfondo que encierra cierta crítica" (De la Puente y Quintana, 1996: 131).

En este sentido, la temática de la diversión oficiaba como una respuesta a la depresión producida por la dictadura militar, y la alegría contrarrestaba el desánimo provocado por los horrores del terrorismo de estado. Esta decisión fue utilizada, quizás, como una herramienta de acción política de fuerte firmeza disruptiva que patentaba la incorrección política tan propia de la cultura rock.

Las bandas de orientación pop entonces, interpelaron lo social con letras divertidas y celebratorias que funcionaron en los comienzos de la democracia desde una idea de destape y desprejuicio. En tanto, su crítica e intimación se debatía entre aspectos sociales y políticos que funcionaban en coincidencia con las tramas de la cultura oficial democrática $\mathrm{y}$, asimismo, actuaban como impugnación a los tradicionalismos. La estrategia paródica constaba de homenajes y variantes ensayadas con el objeto de transitar la post-dictadura desde un campo táctico. Se debía enfrentar una condición de miedo y la inercia terrorífica provocada por la última dictadura militar.

En función de ello, el humor se utilizó como herramienta para la elaboración de un discurso irónico y paródico que apelaba a la ambigüedad y los correspondientes efectos de sentido. La ridiculización de algunos aspectos o la puesta en crisis de ciertas temáticas veladas en la década del 60 y del 70 permitieron comprender una voluntad de 
disputa con el poder enunciativo que atacaba las libertades del individuo.

El empleo del humor y la ironía supuso una reivindicación de la contracultura rock que, en tiempos de masificación, podía alcanzar una disminución en su distinción hegemónica. Por esto mismo, las líricas que fueron comprendidas de un modo pasatista o meramente divertido, en la actualidad pueden leerse como cuestionamientos a los poderes sociales de turno (religión, militares, políticos, sindicalistas, sentido común).

\subsection{Análisis de líricas}

Las líricas que se presentan a continuación, detallan una construcción discursiva de la libertad desde una orientación paródica o irónica. De esta manera, se destacan ocho líricas que articulan una discursividad temática en torno a la parodia cotidiana, la instancia del baile y la liberación sexual:

1) "Jugando al Hulla Hulla" de Los Twist que retoma paródicamente una instancia festiva de juego en la que el humor funciona como recurso para apreciar un espacio de libertad, consumo y recreación.

2) "Rodillas" de María Rosa Yorio se centraliza en la seducción del baile y el hecho de bailar como mecanismo de libertad. El discurso propuesto por la lírica remarca la presencia de las rodillas como un punto de partida para iniciar el movimiento hacia un nuevo universo de concepción.

3) "Guitarras blancas" de Los Enanitos Verdes articula una defensa de la diversión a partir del baile. En este sentido, la cultura rock se construye como un escenario de dispersión, baile y propagación de la transformación, resaltando así su objeto más simbólico: la guitarra.

4) “Los viejos vinagres" de Sumo propone un recorrido lírico desde una enunciación de orientación urbana en la que la libertad es puesta en juega según coordenadas de autenticidad y legitimidad en un universo de baile.

5) "No me empujes" de Andrés Calamaro plantea un discurso en la que la libertad se vuelve un eje para optar por decisiones individuales y opciones de vida que se rigen en virtud de olvido a partir del baile.

6) "Sin Disfraz" de Virus expone las oportunidades de liberación en tiempos de democracia y los efectos liberadores que proyectan estos hacia la vida cotidiana y su relación con lo bailable. 
7) "Dietético" de Soda Stereo articula distintos modos de advertir los cambios de época en relación con el consumo juvenil y, de la misma manera, construye ironías en función de las nuevas tendencias consagradas tras la recuperación democrática y el ocaso de la dictadura militar.

8) "Hay que hacer la cola" de Viuda e Hijas de Roque Enroll desarrolla un trabajo lírico profundo sobre la temática corporal relevante en tiempos de destape y aborda un discurso sensual y sexual superlativo.

\subsubsection{Yo me tiro al piso}

"Jugando al Hulla Hulla”

Los Twist (1983)

Los Twist fue una banda formada y liderada por "Pipo" Cipolatti en 1982 en la que participaron, entre otros, Fabiana Cantilo, Hilda Lizarazu, Daniel Melingo y Gonzalo Palacios. La agrupación es una de las precursoras de la música divertida, picaresca o, simplemente, humorística dentro del rock argentino. Las letras presentaban narraciones irónicas, rasgos lúdicos y melodías bailables, muy propias del estilo musical primigenio de la cultura rock: el rockabilly o el twist.

En este aspecto, la banda retomaba paródicamente los aspectos icónicos de El Club del Clan (otrora rival del universo contracultural del primigenio rock argentino) ${ }^{49}, \mathrm{y}$ ambientaba sus intenciones en un simulacro de las intenciones del rock and de finales de los 50 y principios del 60 (Buddy Holly, The Animals, The Beatles, por citar tres ejemplos). A partir de ello, en compañía de Viudas e Hijas de Roque Enroll o Los Helicópteros, conformaron una tríada que conformaba discursos líricos desde una instancia irónica y humorística sostenida por malos entendidos, juegos de palabras y referencias sexuales.

El disco debut de la banda, titulado La dicha en movimiento, se publicó el 17 de octubre de 1983 y fue producido por Charly García. El álbum se convirtió en un suceso de ventas por la propuesta y la estética sonora, pese a contar con canciones prohibidas por la dictadura militar saliente en el mismo el año de edición: "Había ocho temas bajo

\footnotetext{
${ }^{49}$ El Club del Clan fue un programa televisivo emitido durante la década del 60 que reunió a un grupo de cantantes pop juveniles de amplia difusión en la época. Entre los artistas más destacados y reconocidos se encontraban: Ramón "Palito" Ortega, Raúl Lavié, Nicky Jones, Lalo Fransen, "Chico" Novarro y Violeta Rivas.
} 
censura: 'Jugando al Hulla Hulla porque decía 'huevos', '25 estrellas de oro' porque decía 'al pedo' y por otro lado, 'Perón'. 'En el bowling' porque decía 'la mano blanca, cuidado porque no es un guante"" (Ciccioli, 2010: 231).

En consecuencia, el disco convocó una inusitada tanda de canciones de alta rotación durante 1983 que aún continúan vigentes en la memoria popular del rock argentino: "Pensé que se trataba de cieguitos", "Cleopatra", "Ritmo colocado", "El primero te lo regalan, el segundo te lo venden", "Salsa", "Mocasín” y “Jugando Hulla Hulla”. De acuerdo con las aclaraciones del propio Cipolatti tras el lanzamiento del disco debut, las líricas que integraban estos temas musicales no eran azarosas ni aventuradas: "Las letras son prácticamente de tango, porque son localistas, utilizan los lugares comunes, los refranes y el lunfardo que son típicos de acá” (Canta-rock, 1985: 59).

"Jugando al Hulla Hulla" es una canción que da inicio al primer material y retoma desde la parodia discursiva una estética kitsch construida durante la década del 80, pero ambientada en los 60. Se plantea así una instancia festiva y una vertiente de insistencia en la que el humor funciona como recurso para apreciar una realidad de transición. Por esto mismo, se valoran procedimientos pretendidamente distendidos y lúdicos.

De esta manera, los enunciados abren un escenario en el que la primera persona del singular se presenta como referencia y, en ciertas instancias, emplea la primera persona del plural con intensiones inclusivas. El hablante propone un discurso que se enlaza con las estrategias publicitarias y/o de ventas para postular un espacio ilógico en el que la diversión se centraliza a partir de un juego. Este recreo lúdico permite que el locutor centralice una mirada dual y resalte así las instancias libertarias del juego y el baile, en el que el movimiento se despierta ante un letargo cotidiano y generalizado.

"Hulla Hulla está en las calles y en los kioscos de tu barrio. Y ya comenta la gente: ‘'Ay! Qué juego tan

$$
\text { raro',". }
$$

En esta estrategia discursiva de orientación publicitaria, se anuncia el Hulla Hulla como una venta, utilizando argumentos que destacan las bondades de un producto. De este modo, siguiendo a Maingueneau, se procura persuadir asociando los productos que promueve a un cuerpo en movimiento, a una manera de habitar el mundo: "A través de su enunciación misma, la publicidad, apoyándose en estereotipos evaluados, pretende encarnar así lo que prescribe" (2010: 1). 
En la lírica, el hablante retoma la idea del baile y el juego con la intensión de entrelazar las voces de otros enunciadores que participan desde la crítica y el prejuicio por el movimiento de pelvis. No obstante ello, esta diferenciación permite un acercamiento persuasivo con el interlocutor, a fin de consagrar el objetivo de movimiento y ansiedad en libertad.

“Apurate a conseguir el tuyo que en mi kiosco ya está agotado.

Todos tienen ya su aro con el movimiento centro-americano”.

El ánimo colectivo se destaca a partir de la puesta en común del juego, presente en las zonas más dispares de una gran ciudad o, quizás, de un país. El juego abre el panorama de la diversión desde distintos puntos de un escenario y de la vida misma:

"Hulla Hulla en las veredas. Hulla Hulla en las escuelas.

Hulla Hulla en las canchas. Hulla Hulla ya se juega.

Hulla Hulla en los bares y en los 36 billares. Hulla Hulla en los clubes, en el cielo y en las nubes".

Por tanto, el concepto Hulla Hulla, más allá de su relación lúdica y banal, confluye en una discursividad que metaforiza a la libertad. La puesta en escena destaca entonces una participación activa de la cotidianeidad contextual y de la posibilidad de emplear el juego en un momento clave y de actualidad (ya se juega). El juego, que enlaza y atraviesa libertades, forja uniones y contrae beneficios para los usuarios, según la propia definición del hablante:

"Si querés tener levante, tenés que aprender el juego con la pelvis bamboleante, que se marquen bien los huevos. Hay que ver cuando bailan las chicas, revoleando las polleras, con la argolla en la cintura. Yo me tiro al piso, esto es la locura”.

Esta perspectiva habilita un nuevo vínculo con las cuestiones cotidianas, pero desde un aspecto erótico y lúdicamente sensual. El discurso se torna así, a partir de la estrategia enunciativa, en un vehículo para construir una escena de baile trasgresor, juvenil y de aspiración alegre. 


\subsubsection{A girar, todos a bailar}

"Rodillas"

María Rosa Yorio (1987)

"Rodillas" es la canción que le da título e inicio al sexto álbum solista de Maria Rosa Yorio, publicado en 1987. El material marca una línea pop mucho más profunda que la presente en los discos previos, y propone un sonido moderno a partir de la colaboración musical de los integrantes de bandas que estaban renovando la escena del rock argentino como Metrópoli y Los Encargados.

Si bien Rodillas marcó el alejamiento de Yorio de la escena masiva del rock argentino, es posible pensar que es un disco que permitió trazar un último eslabón de discurso humorístico y festivo, y marcó también el final de un estilo de escritura que sería poco retomado durante la década siguiente. En este sentido, la idea de la canción "Rodillas" tiene una referencia directa que se vincula, desde lo sonoro y lo lírico, con la canción publicada por la banda estadounidense OXO, titulada "Whirly Girl” y editada 1983. Este tema, más allá de lo musical, tiene un abordaje lírico muy similar al que se aprecia en "Rodillas" porque hace hincapié en la seducción del baile y el hecho de ver bailar.

En lo que refiere a "Rodillas", el discurso propuesto articula un diálogo entre una primera persona del singular y otra segunda que se encuentra ante una indecisión. Es por esto que el yo de la lírica remarca la presencia de las rodillas como un punto de partida para iniciar el movimiento, aunque sea en estilo jazz: no olvides tus rodillas, no, si querés bailar algo como el jazz, nene".

Por consiguiente, la propuesta se vincula con una celebración del actuar y un desplazamiento de reflexión hacia la concepción de la vida a partir del baile. En este aspecto, el hablante cambia de destinatario, no se centraliza en una individualidad y se dirige a un colectivo con el objeto de remarcar una idea de movimiento y defensa agrupada en función del divertimento. Se expone así una instancia activa para integrar a los interlocutores e invitarlos a un escenario festivo, alejado de una argumentación tediosa y cercana a un área de esparcimiento: ¡Oigan! Rodillas en el suelo, si, en el aire van juntas con 'papá, papá,",.

Desde esta demanda, tanto el juego como el baile se destacan en virtud de una perspectiva que convoca un desempeño desde el compromiso y la responsabilidad, en pos de incluirse en la partida. En este sentido, la referencia coloquial a la unión de 
piernas o de rodillas (papá, papá) permite comprender una voluntad de danza y recreación.

"Lastímalas un poco, así es como jugar.

Stop con escapar. Arrastrándolas como un bebé".

Por ello, se advierte una crítica al escape, aplicada en función de una interferencia léxica que pretende exponer un lenguaje más dinámico e integrador en relación con la articulación con el inglés (stop con escapar). El juego, de un modo consecuente, le abre las puertas a una tematización de libertad vinculada con la obligación de divertirse y de divertir al otro, enunciado desde la segunda persona del plural las intenciones de generar un nuevo panorama contextual.

\section{"Mundo nuevo para ver. Yo les dije déjenme jugar ¿es tan caro el precio de la libertad?".}

En este aspecto, el hablante se inscribe en el discurso, participa del rasgo enunciativo y aporta un interrogante que encierra un devenir retórico, puesto que destaca la simpleza de alcanzar la libertad a partir de la diversión y el despojo. Al respecto, el hablante centraliza la referencia en un locutor que, ante la quietud, recibe mandatos y es convocado a la recreación nocturna, tomando en consideración un escenario de baile y encuentro: tienes la noche para viajar en tus rodillas, así que ya no puedes parar.

En este sentido, el hablante prosigue en su argumentación y resalta los beneficios que comportarse libre a partir del baile o el juego desde la diversión. El rock se postula como una zona de tensión en la que convive la ansiedad y los alcances libertarios de la música y los roces humanos (baila, baila, baila con el rock).

El compromiso, que se anunció anteriormente, es retomado como un vínculo con el baile, pero también con el sentimiento de vivir la libertad desde la pista de baile y el terreno de la cultura de los encuentros. El baile, asimismo, se torna como un espacio de transformación en el que las rodillas acompañan una sintonía contextual de regocijo y de búsqueda igualitaria.

“Con rodillas y con tu corazón.

Arribas las polleras y todos a girar, todas a bailar. 
Y no pagues ni un peso más ese caro precio de la libertad".

Resulta interesante, en consecuencia, advertir el modo en el que se presenta el baile desde la mirada ajena, puesto que para el colectivo no inclusivo (ellos), el baile es un juego sucio. Este concepto le permite al hablante construir un camino hacia la explicación de la libertad: no sólo el amor comienza desde el denominado juego sucio (bailar) y la memoria de la diversión (no olvides tus rodillas), sino también se toma como el inicio para alcanzar un estadio libre, sin interrogantes.

\subsubsection{Que nos dejen bailar}

"Guitarras Blancas"

Los Enanitos Verdes (1988)

Los Enanitos Verdes es una banda oriunda de Mendoza, formada en 1980 y con una carrera que ha logrado colocarse en puestos importantes de las listas de popularidad de distintos países de Latinoamérica. Su disco debut, titulado con el nombre de la banda, se editó en 1984 y simbolizó un acceso de éxitos en el ambiente del rock argentino a partir de canciones que se han convertido en clásicos de la música contemporánea en español: "La muralla verde", "Simulacro de tensión", "Por el resto", "Te vi en un tren" y "Guitarras blancas".

Esta última canción es la segunda pista del cuarto disco de la banda, denominado Carrousel, editado en 1988 y producido por Andrés Calamaro. Este álbum permitió profundizar la masividad de la banda en el resto de Latinoamérica y, asimismo, impulsó una situación analítica para la propia banda: "Lo que está sucediendo es un fenómeno raro, como una explosión. Por supuesto que no le dicen 'rock argentino', sino 'rock en español' (...) Entonces ves que hay un montón de grupos que venden muchísimo y son super populares" (Rock and pop, 1988: 53).

En "Guitarras blancas" predomina la primera persona del singular y el empleo de la primera persona del plural como modo de defensa de la diversión. Por esta razón, la cultura rock se construye como un escenario de dispersión, baile y propagación de la transformación, resaltando así su objeto más simbólico: la guitarra. En virtud de ello, el hablante articula su discurso como incentivo para defenderse de las críticas que desprestigian la diversión y coartan la libertad de tomar al baile como espacio de 
transformación: una guitarra blanca rompiendo el silencio, es de lo más honesto que yo ahora puedo escuchar.

Por tanto, la guitarra remarca el lugar de la cultura rock y lo ubica como escenario de honestidad y defensa cultural. En función de esta perspectiva, el rock es entendido como un generador de herramientas libertarias que desnuda los enmudecimientos y que da cuenta de los contextos que rodean los acontecimientos (es de lo más honesto que yo ahora puedo escuchar). Al respecto, el reclamo sostiene un acto de libertad y un pedido de desprendimiento hacia una tercera persona que desgasta y corrompe autonomías: "Por favor, déjennos bailar. Por favor, que nos dejen bailar".

Del mismo modo, el enunciado articula una reflexión que se dialoga y se pone en perspectiva para alcanzar razones y argumentos en un trance de lucha por la libertad. La lucha, efectivamente, muestra sus consecuencias en un hablante que se encuentra fatigoso y con intenciones de hartazgo.

\section{"Hoy fue uno de esos días, y me duele la espalda. Y aunque estoy cansado, yo necesito un poco de diversión".}

La referencia al tiempo destaca un contexto de adversidad o de disputa en torno a la orientación bailable. Desde este enfoque, el baile no sólo es postulado como espacio de transformación, sino también como un lugar activador de libertades individuales.

El hablante se expone así ante una situación que retrotrae negativas (hoy fue uno de esos días) y subraya sus intenciones de continuar ganando experiencia en la diversión. La disputa, entonces, se consagra a partir de dos discursos que articulan debates constantes en un contexto que parece referirse al argentino y dar cuenta de un entorpecimiento cotidiano: se refuta la idea que identifica al baile como lugar banalizado y pasatista, y se resalta asimismo la experiencia de transitar un punto de encuentro que enlaza músicas, aditivos y sensualidades.

"No es un escapismo. No estoy bajando la guardia. Yo sólo necesito tan sólo un poco, un poco de diversión. No hablen ahora de Nueva York, estar en Roma o Disney World, Yo sólo quiero que nos dejen bailar acá”. 
En esta estrofa, el hablante parte de una respuesta en la que pone en evidencia una negativa y una intransigencia en la defensa del baile: no es un escapismo, no estoy bajando la guardia, no hablen ahora de Nueva York, estar en Roma o en Disney World. Prosiguiendo en su enunciación, el locutor reclama una toma de conciencia en relación con la diversión como asimilación local, desde una deixis espacial que parece indicar la propia escena que lo inscribe y también el lugar, la ciudad o el país que lo identifica y le permite ser libre: yo solo quiero que me dejen bailar acá.

\subsubsection{Juventud, divino tesoro}

"Los viejos vinagres"

Sumo (1986)

Sumo fue una banda fundada en 1982 y liderada por una de las figuras más legendarias del rock argentino: Luca Prodan. Pese a su corta duración y sus tres discos de estudio, el grupo es considerado uno de los más influyentes de la música contemporánea argentina porque integra, desde su sonoridad, vínculos estéticos y estilísticos con el punk, el reggae, el ska, el $d u b^{50}$, el rock y el pop.

Por tanto, Sumo fue una banda de ruptura que cubrió un espacio de vacancia dentro del rock argentino. Esta virtud se expuso de un modo muy tajante tras el lanzamiento del disco Divididos por la felicidad, que se editó en 1985 y obtuvo una buena recepción a partir de la difusión de "Mejor no hablar de ciertas cosas", "Debede" o "La Rubia tarada", la canción más popular de la banda. En este sentido, a partir del dominio escénico, lírico y musical de Prodan, la banda puso en discusión distintos aspectos psicodélicos, punk y hasta hippies muy propios de la cultura rock anglosajona.

"Los viejos vinagres" es la octava canción del segundo disco de Sumo, titulado Llegando los monos y publicado en 1986. Dicha obra es una de las más celebradas de la historia de la banda porque contiene distintos hits que, por sobre todas las cosas, impactaron tras la muerte de Prodan en 1988: "Que me pisen”, "NextWeek", "Heroin” y "Los Viejos vinagres", que fue el corte principal de difusión.

Las lecturas más habituales, señalan que la letra habla de los públicos de edad avanzada que renegaban de los cambios de la sociedad, de las posturas juveniles y de los gustos

\footnotetext{
${ }^{50} \mathrm{El} d u b$ es un género que proviene de la sonoridad reggae, y que se origina a partir de efectos electrónicos, ecos, efectos y re-mezclas de grabaciones previamente elaboradas o publicadas.
} 
musicales de estos últimos. Los viejos vinagres como rótulo, manifiesta una denigración de esos mayores disconformes. El hecho de vincularlos con lo líquido y lo avinagrado, los relaciona con situaciones amargas y hurañas, muy propias de los comentarios hacia la liberación de los jóvenes.

No obstante ello, también se puede apreciar cierta crítica a la postura de los jóvenes que, al igual que esos mayores, defenestran todo tipo de cambio social o de diversión liberadora. Al respecto, la investigadora Constanza Molina sostiene que en las letras de Sumo se advierte una crítica social que suele aparecer en tono sarcástico o de un modo velado que no permite identificar un plano real: "La pluralidad de voces en diálogos que abarcan toda o parte de la composición se mezclan con metáforas y alegorías a través se describen hechos y personales -reales o ficticios- sin ser estos demasiados explícitos" (2008: 45).

Del mismo modo, el investigador Matías Bradford señala que la lírica de Sumo posee una opacidad que despierta curiosidades porque invoca palabras o enunciados fragmentarios que funcionan como acordes e incógnitas de una resonancia directa o demorada: "Voces de la calle, de un negocio, sonidos de máquinas, risas (...) Las letras no son decisivas lo que importa son ciertas palabras" (2013: 121-122).

Siguiendo las consideraciones de Blanco y Scaricaciottoli, las letras de Sumo plantean una estética de no-claudicación y un grito de furia tensionante hacia una sociedad que intentaba reconfigurarse y reconvertirse con ciertas dotes de esperanza, pero también con fuertes situaciones de realismo feroz. En función de ello, el sarcasmo en las canciones de la banda se explaya en un inventario de tipologías de "personajes urbanos, provincianos hambreados, pero solícitos, yuppies, artesanos, remanentes hippies de otrora y niños bien de zona norte, para quienes el rock es un consumo más, reseñas de una fábula babilónica que vivía en Buenos Aires” (2014: 128).

"Los viejos vinagres" puede entenderse entonces como una crítica a un sector juvenil que se comporta con tradicionalismos y éticas reaccionarias que obstruyen la diversión. El mismo Prodan sostenía en entrevistas que sabía muy bien a quién les estaba hablando en esa canción porque inquietaba e interpelaba directamente "a la gente de 'La rubia tarada"” (Guerrero, 1994: 163). Sobre este punto, merece destacarse el comentario que el fallecido líder de la banda enunció antes de tocar "Los Viejos Vinagres" en el festival Chateau Rock de 1987: 
El rock también es una forma de darle una pequeña patada en la parte de atrás del cuerpo a los dichos viejos vinagres que abundan... Ojito, los viejos vinagres pueden no tener 70, 60, ni 30. Es gente con una mentalidad. Hay chicos de 12 años que son más reaccionarios que una persona de 50. Y encima son más idiotas. Entonces le vamos a dar. Este no es un tema de la juventud contra los más grandes, no ${ }^{51}$

"Los viejos vinagres" inician el recorrido lírico desde una enunciación muy urbana, pero también integrada por interferencias léxicas que unifica la lengua inglesa con la castellana. En este aspecto, la canción comienza con una motivación, pero también con una advertencia. Existe un locutor que postula un interlocutor modelado por la pose y los términos de la nueva moda. En función de ello, el yo de la lírica se construye desde un lugar de conocimiento, que su interlocutor desconoce o no toma en cuenta: dale, dale con el look, pero no termines como el Capitán Cook. Para vos lo peor es la libertad.

De esta manera, la libertad articula un escenario de diversión y esparcimiento para que la segunda persona actúe de diferentes maneras estructuradas por el sistema. Por esta razón, la relación entre el look y Cook, más allá de la rima, se aprecia como un consejo que define una cuestión: si la línea de vida que continua su interlocutor es la de el look o la moda, podría terminar como el Capitán $\operatorname{Cook}^{52}$, es decir, muerto por aquellos que resistieron a su conquista.

A partir de estos enunciados, el locutor construye una estrategia de crítica que supera lo antedicho y se ubica en una instancia más profunda. El yo de la lírica advierte cierta decepción, se muestra ajeno y hasta embestido por un conjunto de personas que, más allá de sus estilos, modos o posturas de orientación juvenil, se comportan de un modo tradicional y reproductor de sistemas añejos: estoy rodeado de viejos vinagres todo alrededor.

Continuando con esta idea, el locutor toma ribetes socarrones y de burla hacia esa segunda persona y le remarca su actitud continua de figurar y representar discursos corporales que le quitan autenticidad. Por tanto, los sitios que se exponen para la discusión y para la puesta en práctica de las falsas posturas son la discoteca y el bar.

\footnotetext{
${ }^{51}$ Título del video: "Sumo - Viejos Vinagres - Chateau Rock - Marzo 1987". Fecha de publicación del video: 16-02-2012. Web: https://www.youtube.com/watch?v=Bb_U2YU6nUg. Fecha de acceso: 11-102016.

${ }^{52}$ Navegante y cartógrafo británico asesinado en el año 1779.
} 
Estos lugares permiten que las representaciones de los jóvenes se lleven a cabo en un ámbito de libertad, pero también en un ambiente con coordenadas que profundizan una identidad vinculada con la exposición y la falsedad, en donde solo importa sobresalir en el espacio y cometer el mínimo error posible:

"No te olvides de posar... en la disco o en el bar.

Para vos lo peor es resbalar”.

La consideración final que propone la lírica se vincula con una intertextualidad que realza el hecho de ser joven y comprender que dicha franja etaria es un reservorio que debe cuidarse y conservarse: juventud, divino tesoro. Esta propiedad polifónica se relaciona con el típico refrán que celebra a las juventudes y sus experiencias, pero también remite al inicio del poema "Canción de otoño en primavera” del escritor Rubén Darío: "Juventud, divino tesoro, iya te vas para no volver! Cuando quiero llorar, no lloro... y a veces lloro sin querer...". Continuando esta idea, la canción de Sumo reconfigura el ideal propuesto por el poema de Darío y ejerce así una crítica paródica al ubicar ese enunciado como final. Se manifiesta entonces la inexistencia de la separación entre esos viejos vinagres y esa supuesta juventud atesorada que no ofrece su mejor versión en el universo de la diversión.

\subsubsection{Ya se van las luces}

"No me empujes" Andrés Calamaro (1988)

Andrés Calamaro es uno de los músicos más representativos del rock-pop argentino de los últimos treinta años. Participó como integrante en la segunda formación de Los Abuelos de la Nada, fue uno de los líderes fundacionales de la banda argentino-española Los Rodríguez y es actualmente un solista reconocido a escala continental.

Pero más allá de su desempeño como músico, también ha participado como productor en discos claves del rock argentino. Entre ellos se puede contar los álbumes debut de Don Cornelio y la Zona y Man Ray, el segundo disco de Los Fabulosos Cadillacs (Yo te avisé!!) y los discos consagratorios de Los Enanitos Verdes durante la década del 80 (Contrarreloj, Habitaciones extrañas y Carrousel). 
El primer disco solista de Calamaro, titulado Hotel Calamaro y editado en 1984, demostró su talento para las canciones bailables, las letras fragmentarias y las melodías pegadizas. No obstante ello, su carrera solista no tuvo un despegue directo durante la década del 80, sino fue en la década siguiente que tuvo reconocimiento masivo y de alcance internacionalista. En este sentido, como autor y creador de canciones insignes del rock argentino, Calamaro ha sabido generar un repertorio poético repleto de búsquedas, experiencias y reflexiones vinculadas con el amor, la música, el vicio, la sociedad y la libertad que lo destacan como artista de la contracultura (Mascia, 2008: $160)$.

Particularmente, la lírica "No me empujes" se ubica como la octava canción del tercer disco de Calamaro, titulado Por mirarte y publicado en 1988. Si bien este álbum no sintetizó un camino de éxito para el músico y tuvo una buena recepción por parte de la crítica especializada (lo mismo ocurrió con el trabajo Nadie sale vivo de aquí, editado en 1989). Por esto mismo, la obra contiene dos de las canciones más conocidas de Calamaro en su etapa solista de los 80: "Carta sin marcar" y "Loco por ti".

La letra en cuestión plantea un discurso de respuesta por parte de un locutor que comienza a la defensiva. Hay, desde un principio, una negación y distanciamiento con respecto a la segunda persona. Sin embargo, se plantea también una estrategia oscilante en ese diálogo de demandas porque el locutor expone cierto desinterés, pero asimismo cierto temor a los desánimos. En este sentido, es posible pensar que la enunciación construye un contexto adverso y de momento complejo en el que la opción por la individualidad es colocada en crisis:

"No me importan todos tus problemas, así no te quiero conocer. No me empujes a otro abandono, no es un buen momento para perder".

En consecuencia, la lírica expone cierto momento de reflexión para el hablante, puesto que destaca un escenario de ocaso o de conclusión, en la que la oscuridad comienza a ganar terreno y articula una idea de escape que hasta el momento se desconoce si tiene una proveniencia benévola o maligna. El hablante no parece estar a gusto con esta situación y por ello mismo lo aclara, pone en tensión está elección de huida y convoca incertidumbres: 


\section{"Ya se van las luces en el horizonte. \\ Todo tiene un final, todo termina (presente). \\ Por un momento te voy a dejar sola, no es un trago fácil para mi”.}

En referencia a este enunciado, sirve destacar la presencia de la expresión todo tiene un final, todo termina, vinculado a un pasaje de la histórica canción de Vox Dei, titulada "Presente" y editada en 1970. En este aspecto, la utilización de dicho enunciado, sirve para poner en tensión un momento crucial de la lírica porque exhibe ciertas decisiones que se advierten amargas: todo termina, no es un trago fácil.

La estrofa siguiente da una respuesta lo antedicho, pero brinda un aspecto más festivo y escapista. El destino del hablante parece construirse a partir de un escenario de fiesta o de divertimento que mantiene los estereotipos de la cultura rock. Por esta razón, los procedimientos polifónicos vuelven a conjugarse y se destacan en virtud de vestimentas relacionadas con el comienzo del estallido de la cultura rock. Asimismo, la noción profunda del baile es comprendida desde tres perspectivas: como una pauta de liberación, como una práctica para llevar en los lugares más recónditos y como un modo polémico de continuar, pese al dolor y el ardor.

"Zapatos de gamuza, zapatos de charol.

Bailando al compás de la liberación.

Bailando en los rincones más dorados de la ciudad,

bailando sobre la sangre de los demás”.

En función de la revelación y de la puesta en común del baile, los clichés de la cultura rock de los 50 y parte de los 60 se ponen en cuestión a partir de los zapatos de gamuza que recuerdan a los azules enarbolados tanto por Elvis Presley, en el universo anglosajón, como por Moris en el terreno local. Del mismo modo, los zapatos de charol destacan un conjunto sinóptico que diversifica distintos mundos culturales: el de al moda, el de la danza y el de la música.

De acuerdo con Blanco y Scaricaciottoli, el empleo del enunciado bailando sobre la sangre de los demás tiene una connotación directa con el desprendimiento del pasado de horror instaurado por la dictadura militar. En este sentido, dicho enunciado cobra una doble reflexión si se lo coloca en crisis: por un lado, aborda el pasado reciente de las 
desapariciones y el terrorismo de estado, y por otra parte subraya un presente de baile que también no permite especular por las exclusiones producidas en tiempos democráticos (2014: 50).

La estrofa final exterioriza la distracción pese a todos los temores y sostiene los temas más claves detallados anteriormente. El hablante refuerza el desinterés, destaca su voluntad de no sentirse presionado y recarga sobre el interlocutor su posible decisión de abandono, quizás reiterado a esa altura. La referencia individual, en ese caso, resulta cada vez más intensa porque el locutor focaliza desde su propia mirada y subraya así su libertad de acción y de baile en desmedro de toda sujeción o situación adversa:

\footnotetext{
"No me importan todos tus problemas no me empujes a abandonarte de nuevo, no es un trago fácil para mí. Bailando sobre la sangre de los demás.
}

Frente a esto, cabe señalar que la lírica desencadena una operación interesante que se aprecia de un modo reflexivo con el propósito de generar culpabilidades en un interlocutor determinado y profundizar así las reglas de la libertad del hablante. En este aspecto, la libertad del hablante prima sobre la de su interlocutor y se vuelve un eje para optar por decisiones y opciones de vida que se rigen en virtud de olvido y el baile.

\subsubsection{No me preocupa parecer vulgar}

"Sin disfraz"

Virus (1985)

Como señala el escritor Jorge Monteleone, Virus representó una tendencia muy importante para el rock argentino en los tiempos finales de la dictadura, puesto que se oponía a la brutalidad de la represión de un modo estratégico y celebratorio: utilizaba las ceremonias del baile y el goce como conjuro (2002: 38). Por esta razón, la apertura democrática de 1983 implicó un despegue necesario para la banda porque significó entrar en acción con líricas desestructuradas, sonidos sintetizados y modernos y una conciencia de la corporalidad muy específica: "La democracia que se venía era festejada por todos, para Virus, que tenía una conciencia política a flor de piel como casi ningún 
otro grupo de los denominados modernos, con el peso de un hermano desaparecido, por lo menos le despertaba una interrogación” (Blanco y Scaricaciottoli, 2014: 63).

La aparición de los álbumes Relax (1984) y Locura (1985) permitieron el despegue masivo de la banda que, hasta entonces, tenía un reconocimiento popular intermedio. Locura, por su parte, contiene una cantera de canciones históricas para la banda y el rock argentino en general: "Una luna de miel en la mano", "Pronta entrega", "Tomo lo que encuentro", "Pecados para dos" y "Sin Disfraz". De acuerdo con ello, el tecladista y actual cantante, Marcelo Moura, señala que Locura fue la obra que puso a Virus, definitivamente, en un plano masivo y más popular: "Cuando salió ese disco fue una verdadera explosión y en poco tiempo era número uno en casi toda Latinoamérica (...) Éramos un grupo ya maduro y asimilamos la presión con soltura" (2014: 119).

Al respecto, el álbum resultó uno de los más importantes de la década del 80 a causa de sus líricas innovadoras, provocativas y eróticas. En este sentido, el disco planteó un acercamiento a una poética sexual, erótica y supuestamente frívola, en comparación con las consideraciones propuestas por el rock argentino más tradicionalista. Por esto, el artista Roberto Jacoby (uno de los letristas colaboradores de la banda) señala que Locura plantea en sus líricas una tensión libertaria desde un espacio de género y se aísla de una topología discursiva heteronormativa del rock: "Lo que hacíamos nosotros era hablar del sexo como es, con todas las posibilidades, que son muchas y muy diferentes: hacerse la paja, mirar, espiar por un agujero, ser puto, ser Taxi-Boy, cualquier cosa" (Sánchez y Riera, 1995: 128).

"Sin Disfraz" es la séptima canción de Locura y es además, una de las líricas más reveladoras del disco porque expone las oportunidades de liberación de los sujetos homosexuales en tiempos de democracia. En este sentido, el cuerpo es entendido como un medio que vincula a las personas con el espacio y el contexto de las situaciones, y como la parte fundamental para alcanzar una libertad plena y verdadera. Así, lo urbano y cotidiano se caracteriza por ser un sitio que imposibilita los vínculos personales y los sumerge en la superficialidad.

"A veces voy donde reina el mal, es mi lugar llego sin disfraz.

Por un minuto abandono el frac y me descubro en lo espiritual, para amar. Como si fuera mentiroso y nudista en taxi voy hotel Savoy y bailamos, y ya no se si es hoy, ayer o mañana”. 
El yo de la lírica muestra una pretensión de liberación que vivencia de un modo limitado (o autolimitado) y abandona el universo simbólico de la apariencia. De esta manera, el hablante se contrapone a la formalidad (por un minuto abandono el frac) y construye una tonalidad espiritual que le permite redescubrir su propia voluntad de vida en ciertas instancias.

Siguiendo esta línea, el locutor destaca un desempeño cotidiano que se encuentra entre tramas y códigos que condicionan sus vivencias (disfraces, apariencias). De este modo, se configura un campo semántico a partir de expresiones ligadas al vestir y desvestir: (sin disfraz, frac, nudista, me visto demodé). Asimismo, lo que refiere a la vestimenta aparece ligado a la rectitud, lo convencional y lo opuesto a la autenticidad (las expresiones abandono el frac o llego sin disfraz refuerzan el abandono de las poses o las apariencias). En tercer término, el concepto nudista aparece asociado a la mentira y se advierte como otra forma de disfraz en tanto que se lo piensa como una postura (como si fuera mentiroso y nudista). En contraste, la desnudez, el cuerpo, la sensualidad o su recuerdo parecen conectar con el verdadero ser (persiste el olor de esa piel morena, sensual, perfumada), de modo que no existen preocupaciones por la imagen (no me preocupa parecer vulgar).

\footnotetext{
"Fue ayer, persiste el olor de esa piel, morena y en sensual, perfumada. $Y$ hoy me visto demodé y normal, no me preocupa parecer vulgar".
}

Por tanto, el cuerpo actúa como una herramienta de liberación que cede ante los bordes sexuales en un lugar donde los demás creen que reina el mal. Sin embargo, a partir de esta expresión, el yo desafía a la moralidad conservadora e introduce la voz de otros. Este rasgo polifónico le permite ironizar y defender su lugar (es mi lugar), un espacio en el que se presenta sin tapujos, separado de los prejuicios y del ropaje urbano. De la misma forma, la construcción como si es otro modo de introducir las voces de los que juzgan, puesto que el enunciado como si fuera mentiroso y nudista implica por lo menos la presencia de dos voces: la que afirma que es mentiroso y nudista, y la que niega esa posibilidad (decir como si fuera, implica decir no lo soy).

Continuando esta profundización discursiva, "Sin disfraz" plantea tres tipos de presente. La primera estrofa se desarrolla a partir de un presente de hábito que indica una 
repetición de acciones (o procesos que se dan en la época del hablante): a veces voy donde reina el mal, es mi lugar llego sin disfraz. Por un minuto, abandono el frac y me descubro en lo espiritual, para amar. Por su parte, en la segunda estrofa se observa cómo este principio de hábito se entrelaza con un presente evocativo: como si fuera mentiroso y nudista. En taxi voy, hotel Savoy y bailamos. Y ya no sé si es hoy, ayer o mañana. Y por último, en la estrofa final aparece un presente propiamente deíctico que se marca a través del tiempo (hoy) y el pronombre personal (me): fue ayer, persiste el olor de esa piel, morena y sensual perfumada. Y hoy me visto demodé y normal, no me preocupa parecer vulgar.

La lírica presenta también dos connotaciones importantes sobre la temática homosexual. Por un lado, se realiza así un juego léxico con la actividad del Taxi Boy (en taxi voy, hotel Savoy) ${ }^{53}$ y por otro se traen a colación voces que reivindican las prácticas homosexuales. A veces voy donde reina el mal es una expresión que, por cierto, puede considerarse irónica porque refiere a los lugares de encuentros gay desde la perspectiva de quienes los condenan ${ }^{54}$.

Por esta razón, el hablante juega con la idea de mostrarse en pose (como si fuera mentiroso y nudista) y construye su discurso a partir de las rimas lúdicas y sonoras que evidencias un cariz netamente sexual: en taxi voy, hotel savoy y bailamos. Y ya no sé si es hoy, ayer o mañana. Este desplazamiento que le permite descubrir lo espiritual y su verdadero yo también lo aísla de la noción del tiempo y lo entrega por completo al placer.

53 Es por ello que el periodista Pablo Schanton señala que "Sin disfraz" postula una situación “anagramática" porque cuenta historias paralelas, más allá de la linealidad que pueda tener el texto: "Es ese juego entre el nudismo y la mentira que define esta y otras letras de Virus (...) Aquí todo se torna denso cuando se habla del reino del mal y de un taxi... Se quiebra la oración” (2008: 141).

${ }^{54}$ Al respecto, María Seoane señala que los pubs y las discotecas de las principales zonas céntricas del país, funcionaron como epicentro por excelencia del encuentro gay. Para ejemplificar, la periodista cita una nota publicada en la revista El Porteño en la que se destaca el carácter de ghetto de las disco gay: "Este pequeño espacio de libertad homosexual paga, donde un hombre puede bailar frente a otro o besarlo inclusive sin que los parroquianos se escandalicen, tiene rasgos concentracionarios (...) para que alguien sea admitido tiene que vestir de forma que dé imagen de cierta prosperidad material y de cierta 'modernidad"' (2008: 334). 


\subsubsection{Sacude tu cuerpo libre}

"Dietético"

Soda Stereo (1984)

Soda Stereo fue una de las bandas más importantes del rock argentino y de la música hispanoamericana en general a raíz de su masividad, su influencia estilística a lo largo de toda su carrera y sus distintas canciones catalogadas como clásicas en la memoria popular. Liderados por Gustavo Cerati, se formaron en 1983 y a lo largo de sus años tuvieron un papel muy importante en el desarrollo y la difusión del rock-pop iberoamericano durante las décadas del 80 y 90.

El disco debut del trío se publicó en 1984 bajó el nombre Soda Stereo y fue producido por el líder de Virus, Federico Moura. Sin dudas, el álbum profundizó aún más la presencia estética de Soda Stereo, puesto que en sus inicios se lo vinculaba con la música pasatista, "plástica" y "optimista" que se vinculaba con los desarrollos new wave y, al mismo tiempo, también era criticada por los rockeros de los 70 .

A pesar de las críticas iniciales y las constantes diferenciaciones, la obra obtuvo un despliegue propio para la banda y dejó una cantera de canciones recordadas a nivel continental: "Trátame suavemente", "Sobredosis de TV”, “Un misil en mi placard", “Te hacen falta vitaminas”, “¿Por qué no puedo ser del Jet-Set?” y “Dietético”.

Hacia esa época, Soda Stereo transitaba un discurso de tonalidad pop que rescataba una tradición erótica y fascinada por cierto glamour con el objetivo de reconstruirlo y redireccionarlo a partir de representaciones que lo tensionaban. No obstante ello, el grupo supo demorarse en un estado de excitación muy típico de los aspectos posmodernos: puesta en común de las situaciones a partir del éxtasis, la moda y el erotismo (Blanco y Scaricaciottoli, 2014: 84).

"Dietético" es la quinta pista de la opera prima y es, quizás, la que mejor representa al trío por su oscilante relación con la provocación y el desafío. La lírica articula distintos modos de advertir los cambios de época en relación con el consumo juvenil y, de la misma manera, construye ironías en función de las nuevas tendencias acaecidas tras la recuperación democrática y el ocaso de la dictadura militar. Al respecto, Karen Koch, sostiene que esta canción es la más característica de la primera etapa de Soda Stereo porque pone en manifiesta un vacío y el sinsentido en el que se sumerge la sociedad cuando busca cierta ausencia existencial o nada dietética (2008: 192). 
Las enunciaciones fragmentarias que integran la letra de "Dietético" retoman críticas y exponen ambiguamente construcciones de frivolidad y diversión. La estrategia consiste en apoderarse de las críticas anti-frívolas espetadas por cierto sector del rock argentino, y desde ahí asumirlas y transformarla en identidad con el objeto de desarmar instancias contrarias. El discurso de la lírica juega con la temática de la obsesión por la belleza física y el cultivo del cuerpo marcado por los indicadores de la esbeltez, los modelos de consumo, la apariencia y los incipientes medios de comunicación (Blanco y Scaricaciottoli, 2014: 80).

En este sentido, la lírica presenta la voz de enunciadores dispersos, y es una de las pocas letras de Soda Stereo en la que el hablante predominante se expresa en primera persona del plural. No obstante, emplea un nosotros exclusivo que sirve para englobar a un conjunto determinado de personas. Su empleo no inquiere una unión, sino una diferenciación y un distanciamiento:

"Somos un conjunto dietético, tiramos una onda dietética.

Canciones de amor con sacarina, con menos de una caloría".

Por tanto, la continua reiteración de la metáfora dietético conduce a un efecto de hipérbole y a un juego con imágenes de una estética que privilegia el baile y la diversión (Secul Giusti y Rodríguez Lemos, 2011: 163). Este complejo trabajo polifónico involucra ironías, alusiones a publicidades y modas de la época: (con menos de una caloría, descremadas, sacude tu cuerpo libre, gimnasia jazz). Tanto es así que las expresiones buscando el paraíso estético, nuevas mentes descremadas o consume que no hay peligro exponen una idea que alude a la novedad, la preocupación por la imagen y la superficialidad como principios inspiradores de la vida.

De esta manera, se busca afirmar como identidad los aspectos que acicatean la irascibilidad de los críticos (somos un conjunto dietético) y del mismo modo, se articula un desplazamiento que transita entre discursos publicitarios sobre lo saludable y la imagen corporal: te quiero, pero estás tan gorda, Presiento que no sos moderna.

A partir de esta última expresión se hace presente la voz de un segundo enunciador que ratifica la idea principal del primer punto de vista y presenta un diálogo irónico en el que lo moderno se muestra como eje de las relaciones personales. Siguiendo a la investigadora Natalia Minelli, en esta lírica, el cuerpo da cuenta de los rigores del disciplinamiento, como rincón en el que se debate inclusive el amor o el cariño (te 
quiero, pero estás tan gorda). En clave paródica, el discurso del control advierte una enunciación liberal (por la posibilidad de elección, de optar qué consumir) y acarrea una estigmatización en torno los excesos (Minelli, 2010: 4). Este discurso entonces sirve para vincularlo con la estética del grupo, pero también para profundizar un aspecto determinadamente irónico: somos un conjunto dietético. Giramos una onda dietética. Canciones de amor con sacarina, con menos de una caloría.

Siguiendo a la investigadora Karen Koch, esta expresión señala desde la primera persona del plural una situación post-dictatorial que advierte la caída de todos los valores postulados por los compositores de rock argentino de la época. La inclusión de estos nuevos valores se vinculan, entonces, con la influencia de la televisión, la presencia omnipresente del consumo y la imposición frívola: "La propuesta entonces era resaltar la frivolidad al máximo y responder con ironía, aunque al mismo tiempo se cayera en una contradicción. Esa búsqueda se convertiría en estética e implicaría un uso particular del lenguaje" (2008: 192).

La provocación planteada por los dos primeros enunciadores es subrayada por una tercera voz que parece ubicarse en una situación de enunciación distinta y, además, plantea interpretaciones ambiguas (jel régimen se acabó, se acabó!, jel régimen se acabó, se acabó!). En función de ello, se juega polifónicamente, y de una manera irreverente, con distintos significados de la palabra régimen, entendido como dieta y como sinónimo de dictadura.

Al respecto, Minelli sostiene que este final de canción reposiciona y fisura el mensaje profusamente repetido, recordando, a partir de las calorías y las nadas dietéticas, una cultura que apenas años atrás experimentaba los rigores del régimen militar:

Así, la fábula del control y la disciplina -difundida por los medios masivos- que es el soporte del status de la persona y funciona como pasaporte que permite ser “como se debe ser", es reutilizada invirtiendo la estigmatización: no ya la apología del orden del régimen, sino la explosión liberadora del fin del estado de sujeción (Minelli, 2010: 4).

No obstante, es posible proponer una tercera lectura del concepto régimen, comprendido sutilmente como el conservadurismo menor y solapado del propio rock. Es decir que se entiende como parte de un régimen a todas las críticas tradicionalistas del rock, postuladas a partir de aprobaciones o desaprobaciones de estéticas y modismos 
novedosos. En este caso, el hablante plantea la necesidad de una estética propia y articula una vinculación directa con la complejidad de hacer música rock en los diferentes contextos del país, tanto dictatoriales como democráticos.

\subsubsection{Es el éxtasis total}

"Hay que hacer la cola"

Viudas e Hijas de Roque Enroll (1986)

Viuda e Hijas de Roque Enroll fue un grupo femenino formado a fines de 1983 que perteneció a la escena del movimiento "divertido", junto a grupos como Los Twist, Sueter y Soda Stereo, en sus inicios. La banda se popularizó tras la salida del primer disco, publicado en 1984 y reconocido por la canción "Bikini a lunares amarillos justo, justo", una versión castellanizada del tema “Itsy Bitsy Teenie Weenie Yellow Polka Dot Bikini” del artista de Brian Hyland. En una misma línea, el segundo disco Ciudad Catrúnica integraba los clásicos "Lollipop" (del dúo norteamericano Ronald \& Ruby) y "Plata, plata" (versión del "Pata, pata" de la sudafricana Miriam Makeba).

Viudas e hijas de Roque Enroll se destacó por presentar una imagen de desparpajo, con líricas notablemente desprejuiciadas e irónicas que se vinculaban con la apertura social propuesta por el advenimiento democrático. En este sentido, las letras celebraban cierta estética pop de los 60, cercana al universo beat y bailable, constituida desde una mirada crítica y mordaz de género. Así, las mismas volcaban una representación humorística desde una óptica femenina, "de las tribulaciones de la clase media baja en las instancias de su vida cotidiana, el público que consumía las canciones del Club del Clan y su extensión en el presente de los 80" (Blanco y Scaricaciottoli, 2014: 94).

De acuerdo con la guitarrista María Gabriela Epumer, una de las fundadoras de la banda, hacia un principio el grupo era odiado por tener integrantes mujeres y por plantear una desfachatez tanto en lo sonoro como en lo icónico: "Vendíamos 50 mil discos y las cuatro teníamos una formación musical. Nos criticaban por cuánto nos producíamos, pero después aparecieron unos caballeros con labios pintados de negro y el jopo bien batido. Había una bronquita porque despertábamos algo" (Dillon y Riera, 2000: 33).

La canción "Hay que hacer la cola" es la novena pista del tercer disco de la banda, titulado Vale cuatro y editado en 1986. Si bien este álbum no tuvo una buena recepción por parte del publico, permitió que Viudas e Hijas de Roque Enroll desarrollase un 
trabajo lírico mucho más superlativo que en los discos previos. Dicha canción, por cierto, profundiza una temática corporal relevante en tiempos de destape, puesto que la cola se había impuesto como discurso sensual y sexual en las portadas de las revistas, las publicidades de vestimenta y los programas televisivos nocturnos.

En consecuencia, "Hay que hacer la cola" construye a un hablante desde la primera persona del singular que referencia aspectos cotidianos $\mathrm{y}$, asimismo, generaliza situaciones desde una perspectiva burocrática y paródica. En su enunciación, el locutor apela a la modalidad de enunciación imperativa, imprimiendo rasgos generales y de verdad absoluta, en pos de recrear una instancia obstruida de diversión, vinculada con rasgos de encierro: hay que hacer la cola, uno adelante y otro atrás. No hay escapatoria, todo a su tiempo y sin chistar.

Los enunciados trabajan lúdicamente con una idea picaresca y emanan una crítica de la cotidianeidad con bloqueo de libertad desde una historia que se aprecia coloquial. El hablante, por esta misma razón, apela a la ironía, y desde su argumento totaliza la vivencia como un modo de remarcar la negativa de su presencia en la situación

\section{"Qué sensación tan espasmódica, vamos llegando y calculando la demora. Lo que más amo es esperar, qué vibración tan sociológica. Me gusta tanto estar clavada en la baldosa, un cuerpo a cuerpo popular".}

En este caso, el enunciado se construye a partir de la participación de voces que se contraponen: en primer término, el hablante precisa su llegada, su sorpresa con la situación de la espera que lo aqueja y lo destaca como un momento movilizador y naturalizado; en segundo orden, la ironía se advierte con mayor precisión, puesto que el locutor resalta su ansia de esperar cuando, en verdad, se muestra ofuscado por tal situación; en última instancia, la quietud es presentada como un gusto y un agrado por continuar participando de la demora.

El escenario, por ende, toma ribetes más ocurrentes y no menos irónicos cuando se destacan los aspectos burocráticos de la espera (en la cola) y los sujetos que a partir de ella confluyen: esta terapia puede ser lo más, siempre hay Teresas que confiesan sus historias. Es una droga fácil de ubicar. 
La postulación de la libertad, desde este aspecto cotidiano se construye a partir de la enunciación, como una elipsis obstruida que no se permite alcanzar desde el retraso, el cansancio y el rechazo de un colectivo determinado.

"Nadie soporta pasar cerca de una cola, y como mínimo mirar.

Nadie adelante, sólo uno atrás.

Primer lugar, la ventanilla me devora, esto es el éxtasis total”.

Por consiguiente, la construcción de la libertad es ironizada y se postula su alcance a partir de la quietud y la espera lenta, cuidada, controlada ( $\sin$ chistar) y cansina de los participantes de la fila (cola). Sobre este punto, vale decir que la sensación de encierro ubica un lugar de escapatoria y/o de fuga embelesada que permite comprender nuevas perspectivas sobre la libertad.

\subsection{Consideraciones parciales}

\section{Una política de frivolidad: la construcción de la libertad en la cotidianeidad}

La apertura democrática permitió que los artistas del rock argentino asumieran nuevos esquemas de referencia en un contexto de transición y finalización de la censura. La exaltación del baile presentó a la discoteca como un terreno de disputa y crítica que contemplaba dosis de violencia y de nihilismo, en términos similares. Al mismo tiempo potenció y resguardó, durante los últimos años de la dictadura, las demandas socioculturales y de minorías como es el caso de los colectivos gays, trans y/o lesbianas.

En este contexto, el reordenamiento político y social de tímida vertiente neoliberal dejaba ver posicionamientos individualistas que ofrecían, sin embargo, revalorizaciones de los cuerpos, de modo tal que fue notable el culto al cuerpo joven. A nivel global, y a partir de la fuerte incidencia de la música disco, la consagración de los cuerpos en baile permitió que los fines de semana se convirtieran en un frenesí discotequero: los sitios de esparcimiento bailable se agitaban a partir de "una frenética actividad, creando una cultura propia con base en los bailes, las canciones y las costumbres urbanas en torno a la diversión y el empleo del tiempo de ocio" (Sierra i Fabra, 2003: 316). 
Asimismo, el éxito de las discotecas en la esfera mundial tuvo mucho que ver con el grado en que se consiguieron reunir clientes de muy diversa extracción social y estilos de vida diferentes, desde los heterosexuales residentes en los suburbios ciudadanos hasta los componentes de la comunidad gay, desde las clases trabajadoras (marginales y excluidas en algunos casos) hasta los profesionales de las grandes urbes, vinculados con un estrato social medio (Straw, 2001).

En este aspecto, las líricas que integran este capítulo no advierten características de evasión, sino, más bien, búsquedas propicias en pos de diferenciarse de la solemnidad y acercarse a la diversidad y la libertad. Por un lado, se aprecian referencias al baile como espacio de independencia ("Guitarras blancas"), sensualidad ("Rodillas”) y proposición erótica ("Sin disfraz"). Continuando esta línea, se construye un discurso de corporalidad irónica que postula demandas lúdicas en los términos cotidianos ("Jugando al Hulla Hulla") y destaca asimismo ambigüedades ("Hay que hacer la cola", "Dietético"). En este aspecto, también se revalorizan las críticas hacia la participación en espacios bailables, entendida como simulacro y disposición propicia para la burla ("Los viejos vinagres", "No me empujes").

Por tanto, y en función de estos desplazamientos, el tópico de la libertad resulta fundamental porque ubica al baile y a la cotidianeidad como gesto, ambiente y/o zona tensionante, consagrada a partir de distintas libertades que contribuyeron a forjar identidades y consolidaciones democráticas y civiles.

En consecuencia, el discurso articulado en las líricas permite dar cuenta de una inversión del imaginario social que relacionaba al espacio de la discoteca con la complacencia, el compromiso tibio e inexistente o el simple deleite. Al respecto, la construcción del colectivo ellos también funciona como principio ordenador para poner en común estrategias de sentido que se enfrentan a los discursos desestabilizadores. Se entiende así que tanto las invitaciones del baile como las posturas estéticas son diagramadas en función de un empleo del nosotros inclusivo que acompaña significativamente los cambios de sensibilidad y de expectativa del marco temporal.

Continuando esta idea, el uso del nosotros puede enmarcar tanto a los seguidores de rock-pop, como a los artistas vinculados con la escena bailable y con las nuevas reconfiguraciones de una sociedad en reconstrucción y con presencia ostensible de perspectivas que buscaban la ampliación de derechos. En consecuencia, las referencia al colectivo ellos postula un adversario que puede encontrarse en el pasado de prohibiciones o en el presente de transición democrática que aún reúne creencias 
conservadoras y totalizantes en la cultura rock, los jóvenes y los diferentes sectores de la sociedad. 


\section{Capítulo VIII}

\section{Una libertad en tensión: el yo en perspectiva, entre el aislamiento y el escape}

\subsection{La profundización de la primera persona}

En lo que refiere a lo discursivo, es posible señalar que las líricas del rock argentino del período 1982-1989 tematizaban una libertad con intenciones menos universalistas, empleando un tono de orden individual y apelando a tensiones particulares. Ante esto, la enunciación del yo designaba y exponía a quien hacía uso de la posibilidad de revelar su visión del mundo y el entorno verbal. El yo funcionaba como un punto de partida para vertebrar el discurso y, destacando nuevamente a Benveniste, resaltar el sujeto de la enunciación que se auto-designa por medio de modalizaciones y aspectos valorativos.

El empleo de la primera persona que presentaban las líricas se definía en relación a un otro que oficiaba de enemigo o de adversario sustentador de una práctica de vida dependiente y esquemática que se opone a la centralidad libertaria. Frente a esto, el enfrentamiento se dio en virtud de la hegemonía democrática existente vinculada con jerarquías políticas, convencionalismos sociales provenientes de otras décadas, presión económica y la presencia concreta de una cultura rock cada vez más masiva y mediatizada.

El ejercicio discursivo del yo instalaba a un hablante como sujeto de la enunciación y como conductor del discurso, subyacente a todo enunciado. Por esto mismo, el periodista Alfredo Rosso señala que en tiempos democráticos las letras de rock argentino se caracterizaron por plantear una profundización del yo como punto referente, a diferencia de décadas anteriores donde se pensaba en término de lo colectivo y en utopías de cambio que involucraban al nosotros:

En los 80 cambia todo eso. Lo que es interesante de ver es que el rock argentino en los 80 es como una hidra de muchas cabezas. No hay un mensaje unívoco, exclusivo, y eso es lo más interesante. Hay sí un par de tendencias que hacen punta y que son un poco definitorias, como por ejemplo jerarquizar el baile, el movimiento del cuerpo. El rock argentino adopta esa cosa más física de los 80 , pero al mismo tiempo tiene un montón de contenidos que son significativos, que aportan a la cultura (Pérez Castillo, 2013). 
De acuerdo con Berti, las letras de la transición democrática presentaban un fuerte contenido autónomo (predominancia discursiva del yo, sobre todo) que se diferenciaba de los conceptos que pregonaban la finalización de las ideologías y se relacionaban con una especie de resistencia pasiva de las masas frente a una "socialización estupidizante" en términos de Jean Baudrillard (1994: 42). Del mismo modo, Gilles Lipovetsky advierte una trama de personalización durante la década del 80 que obligó a una mutación en el hacer y en el querer de las sociedades. Por consiguiente, cobró relevancia el deseo de expresión y de expansión del yo, es decir, de una búsqueda de identidad que motivaba acciones sociales e individuales (1993: 8).

En términos musicales y discursivos, se entiende que la cultura disco forjó una cuestión identitaria que emparentaba los acontecimientos bailables con la sensación de vivir y sentir de un modo personal: "La cultura disco como una cuasi-cultura superficial y ególatra o como una retirada regresiva que huía de la libertad anárquica de los sesenta en busca de seguridad: cualquiera fuera el modo en que se lo mirase, parecía indefectiblemente la muerte de la lucha política, el sentido y la izquierda" (Shapiro, 2012: 270).

En este sentido, el contenido lírico de las líricas del rock argentino de los 80 se sirvió de este antecedente global y, a su modo, problematizó la vida en democracia en función de las experiencias juveniles y el marco del proceso de restauración de derechos individuales y sociales.

Los jóvenes de la década del 80 adoptaron modalidades específicas disímiles que invertían los roles, a fin de enfrentar posturas rígidas provenientes del autoritarismo dictatorial: frente a la solemnidad y la disciplina, se ofrecía espontaneidad, desobediencia y atrevimiento en temas eróticos y en temáticas de género (aceptación y visibilidad de las comunidades gays, por ejemplo).

Estas nuevas perspectivas permitieron organizar interrogantes en torno a la comunicación, la cultura y las políticas de género: ¿Quién definía los modos hegemónicos de ser joven en este contexto de transición democrática? ¿Quién regulaba la entrada, permanencia o exclusión de rasgos, prácticas y perfiles de sujeto que confirmaban, negociaban o resistían esas definiciones cristalizadas de la condición juvenil dominante? ¿Cómo operaba, en estos procesos, la ideología y el cambio histórico en torno a los géneros? (Elizalde, 2012: 6). 


\subsubsection{El espacio de la individualidad ¿una clave posmoderna?}

Tras el advenimiento democrático, y como se analizó en el capítulo anterior, las estrategias enunciativas de las líricas se vincularon con formas alegóricas, irónicas y sarcásticas enlazadas con un discurso fragmentario de la cotidianeidad. En paralelo con esta situación controvertida, el rock argentino forjó un territorio suburbano y periférico que acuñó a una gran parte del rock masivo de la democracia. Así, la corriente alternativa del rock argentino pre-democrático se conformó como una usina cultural que planteó de una manera distinta el consumo del rock.

En consonancia, las líricas que integran este capítulo fueron publicadas por agrupaciones de rock argentino que se encontraban en un tránsito de éxito y desarrollaban un alcance muy positivo en lo que refiere a la circulación de la música en los medios de comunicación. Por esto mismo, vale decir que la cultura rock argentina se encontraba en un pico de comercialización muy relevante e inédita para su historia, tanto desde la perspectiva de la exportación a otros países como su presencia en los diferentes recintos del país.

De este modo, los conceptos y los saberes de la libertad fueron reconfigurados en relación directa con la finalización de las dictaduras militares en Latinoamérica. Se comenzó a hablar así de una clave posmoderna que devino en un giro cultural y social polémico en el mundo occidental (incluyendo la cultura pop cinematográfica, musical y teatral que comenzaba a ensamblarse con las perspectivas de una nueva democracia).

La comprensión de lo posmoderno consistió en correlacionar la aparición de nuevos rasgos formales en la cultura con la de un tipo de vida social y un nuevo orden económico, que a menudo se denominó sociedad de consumo, sociedad de los medios de comunicación, o capitalismo multinacional.

Igualmente, lo posmoderno también abarcó distintas manifestaciones del arte importantes en la vida cultural que contuvieron reacciones contra las formas establecidas de la modernidad, y separaciones clave de la distinción entre la cultura superior y la llamada cultura popular o de masas (Jameson, 1990).

Lo posmoderno comenzó entonces, a desempeñarse en oposición a los proyectos políticos-ideológicos y en vínculo directo con cierto nihilismo filosófico. A partir de esta sensibilidad se afirmaron identidades parciales o fragmentarias anteriormente acalladas, se debilitaron las nociones en torno a los antagonismos de clase y la organicidad de la sociedad: 
Fueron posmodernos los relatos breves y "menores", en contraposición a las grandes narraciones de la modernidad. Fueron posmodernas las películas y las novelas un tanto deshilachadas que mezclaban y parodiaban géneros literarios, a la vez que renunciaban a las rupturas abismales de las vanguardias. Fueron posmodernos los cruces y las mezclas de épocas, según el relativismo moral finalmente aplicado a lo estético (Pujol y Satas, 2003: 267-268).

Frente a esto, los músicos de rock-pop argentino no mostraban intenciones de rendirle tributo al pasado y pretendían integrarse a la cultura de masas, con las ventajas y los problemas del caso. Como sostiene Pujol, la fragmentación estilistica de la juventud y la irrupción del punk como factor determinante para conmocionar las recepciones sobre buena o mala música produjeron un dilema de raigambre posmodernista: "Si bien algunos autores consideran que la cultura de los 60 es el principio de la posmodernidad, solo en los 80 , y el fragor de los acelerados cambios políticos y económicos del mundo, el debate irrumpe con toda su fuerza" (2007: 139).

Siguiendo esta línea, la cultura rock argentina incorporó materiales posmodernos durante dicha década con el objeto de revisar, re-actualizar o revitalizar procesos de la industria cultural. De esta manera, también se proliferó un debilitamiento de intencionalidades de protesta, demanda o reyerta contra el sistema o lo sistémico en dimensiones colectivas. No obstante, es posible advertir una construcción discursiva que postulaba una definición del joven, trazado a partir de las coordenadas de la transición democrática, valorando así un costado político cotidiano e individual.

Es posible comprender entonces que las líricas del rock-pop argentino manifestaban una disposición contracultural muy propia del espacio del rock, certificada a partir de una actitud y práctica distintiva, y agrupada en virtud de lecturas, posturas, pequeñas rebeliones y afrentas contra un sistema o una estructura conservadora.

Este último aspecto, de hecho, puede consagrar una posible respuesta a las definiciones que ubican a la juventud de los 80 en una instancia indisponible o vacua. Por esto, conviene remarcar que la interpelación moral realizada sobre los jóvenes de dicha década se enlaza con mandatos ligados a la experiencia y la normativización de los rasgos de otras juventudes (en particular con la de los 60 y 70), “cuya relación con la política suele idealizarse muchas veces sin la necesaria comprensión histórica" (Kriger, 2010: 47). 


\subsubsection{La libertad del aislamiento y la huida}

Desde sus inicios, la cultura rock se mostró alejado de todo índice de fosilización de vida y de experiencia, apartándose también de cierta quietud y estancamiento de existencia. No obstante ello, también forjó una identidad más vinculada al rol de lo íntimo, con la escucha personalizada, parcializada y personal que trastocó ciertas nociones sobre lo libertario y las supeditó a un desarrollo aislado y encerrado.

Durante el desarrollo de la década del 80, la cultura rock universal no abordó reivindicaciones maximalistas, ni tampoco buscó dominar el mundo como proyecto o apelar a afirmaciones grandilocuentes. Lo que se puso en juego se sintetizó en el orden de lo personal e individual. En este aspecto, el rock argentino con orientación o perspectiva pop se alineó sin dudarlo a este diagrama de recambio. Continuando las palabras de Chastagner, no se buscaba reclamar en nombre de los otros, de la comunidad o de la generación. La demanda, en tal caso, se ubicaba de un modo modesto y cauteloso, pero imperioso: "La urgencia no es otra que la del encuentro, la de una escucha, la de una confrontación con otra individualidad, otro cuerpo. No habría que tomarlo como un llamado colectivo, como un grito de adhesión” (2013: 197).

Tomando en consideración el espectro temático del rock, algunas intencionalidades se relacionaron con cierta poética de escape en la soledad y en la introspección. Sin embargo, hacia la década del 80, las letras de rock argentino comenzaron a desplegar estrategias enunciativas que ponían en tensión las prácticas de la vida de los jóvenes en libertad. Se describían estados y características que ponían en crisis la situación de los jóvenes y daban cuenta del lugar cultural de rock como contenedor y generador de espacios de debate.

A raíz de ello, la libertad se configuró como una temática que generaba inquietudes sobre el proceso de aislamiento generado por las distribuciones sociales y los nuevos ejes rectores de la vida: los medios de comunicación, la expansión de la psicología, del trabajo a domicilio y la privatización de las acciones colectivas y los consumos. En función de ello, el individualismo se profundizó al perecer los valores colectivos y forjó una crisis vinculada a la consumación del placer y la satisfacción, relativizando la moral, los aspectos político-partidarios y los convencionalismos. Emergió así la cultura que validaba todas las prácticas y apartaba las concepciones filosóficas integrales que intentaban problematizar y comprender el mundo, el hombre y la existencia (Scatolini, 2011: 345). 
La postulación de la libertad implicaba una voluntad de huir, tanto de las moralidades modernas como del adiestramiento y la disciplina. En este sentido, si bien la situación provocada en tiempos democracia no es distinta a la esbozada por las músicas y las líricas del movimiento rock durante la década del 60 o del 70, es posible apreciar una noción de abordaje articulada a partir de opciones discursivas yuxtapuestas y fragmentarias, que no manifestaban intenciones de narrar historias magníficas o grandilocuentes.

Retomando lo trabajado por Oscar Blanco, es posible señalar que en ciertas líricas de este período predominaba un resabio de la instancia contracultural del hippismo del rock nacional. La subjetividad se sostenía en una línea de fuga, un escape y una huida del sistema que denunciaba una modulación paralela y motivaba también ciertas alternatividades (2012: 285).

Se abrió entonces un avance hacia las carreteras, las fronteras y otros confines con el objeto de apreciar las libertades.

Si la ciudad moderna propone la propiedad privada y la propiedad volátil del dinero financiero, el imaginario desplegado en estas letras propone un nomadismo que se opone y ataca lo establecido montado en una propiedad privada móvil (...) que transita las carreteras atravesando planicies y desiertos, incitando a la rehabilitación de emociones e instintos originales reprimidos mediante la censura y el castigo estatal y social del sistema, muy pronto convoca a un colectivo encarnado en su público (2012: 285).

De esta manera, las modificaciones discursivas propuestas tomaban tópicos ya utilizados por la cultura rock en su consideración global (el amor, el odio, el tedio, la protesta) y se ejercía un empleo primordial de características de fuga y escape en pos de apartarse de las rasgaduras proyectadas en el contexto y conseguir así una mayor autonomía y también una contributiva individualidad.

\subsection{Análisis de las líricas}

Las líricas que integran este capítulo presentan un abordaje individual y hedonista sobre la libertad, entendiéndola como un espacio de escape o de reclusión, según las circunstancias. Las letras abordan una temática de libertad desde dos matrices 
fundamentales: una noción negativa e irónica de estancamiento y de inmovilización, por un lado, y de voluntad de huida y escape, por otro.

En este sentido, las líricas configuran una noción individual de libertad en vínculo directo con una identidad juvenil atravesada por prácticas sociales y actitudes de transformación en democracia. Teniendo en cuenta esto, se analizan ocho líricas que articulan una discursividad temática en torno a la presencia del individualismo y el ideario de fuga o escape de un orden social:

1) "Foto de una jaula" de Sueter destaca una situación de encierro y desgano que expone un relato de tránsito y de introspección en crisis de libertad.

2) "Espirales" de Don Cornelio se encuentra atravesada, desde su estructura enunciativa y metafórica, por una intensidad y una urgencia que destaca un estado de libertad condicionada en zonas urbanas.

3) "Enjaulados" de Fricción propone un signo de urgencia con el propósito de conectar y encontrar una salida en una instancia de libertad confinada.

4) "Héroes anónimos" de Metrópoli propone un recorrido lírico desde una enunciación, dictada por un nosotros inclusivo que refiere a una situación defensiva y de resistencia ante el encerramiento urbano.

5) “Acción y reacción” de La Sobrecarga plantea un discurso que pone en crisis el lugar de los jóvenes en el contexto y ofrece, a partir de ello, perspectivas para no claudicar o abandonar los nuevos sentidos.

6) "Prófugos" de Soda Stereo aborda connivencias plurales en torno a la búsqueda de libertad, pero también remarca una inclinación de individualidad en la enunciación de la huída y el escape.

7) "Soy donde voy" de GIT expone las oportunidades de liberación en términos de viaje y escape individual ante la sociedad alienante y urbana.

8) "Ocho Ríos" de Los Pericos articula un discurso también en términos de viaje, pero con la intención de exponer una situación que, desde un principio, se la sitúa desde un lugar de relajo y descanso. 


\subsubsection{Libre o dentro de una jaula}

"Fotos de una Jaula"

Sueter (1985)

"Fotos de una jaula" es la octava pista del tercer álbum de Sueter, 20 caras bonitas, editado en 1985 y producido por Charly García. El disco es quizás el más exitoso de la banda por la alta rotación de canciones que generó, entre las cuales se conoce: "El anda diciendo", "Vía México" y "Jugo de Tomate Frío", cover de Manal, una de las bandas pioneras del rock argentino.

La canción en cuestión presenta a un enunciador principal que destaca una situación de encierro y desgano. A partir de esa perspectiva, el hablante expone una instancia de desplazamiento de tránsito, desde un movimiento callejero, en busca de un amparo que permita invisibilizarlo: día, explota ya el día. Y yo estoy caminando, buscando un refugio donde estar y poder gritar "ausente".

De este modo, para el protagonista, el día no comienza de una manera habitual, sino estalla de un modo inmediato y atormentador (día, explota ya el día). Este comienzo denota un escenario de calvario y presenta, a su vez, una situación que genera cierto espacio de confortabilidad. La construcción del discurso que precisa al hablante, se muestra de una forma doblegada y con poca importancia con lo que sucede alrededor. El único momento de romanticismo o sentimentalismo se destaca en el enunciado que aproxima a la segunda persona.

"Delirar sentado en una silla e irme al fracaso.

Yo sólo quiero verte sonreír porque algo tengo en claro..."

El yo de la lírica se encuentra en la quietud y habla desde la primera persona. Ahogado en una construcción de libertad que no percibe y en una defensa que estaría puesta en la ilusión (en el hecho de delirar). El fracaso, por tanto, parece vincularse con su cotidianeidad. En esta instancia, el hablante destaca la importancia de tener cierta cercanía con su destinatario e interlocutor, pero a fin de cuentas desvela el motivo de su claridad o su iluminación en la siguiente estrofa. Y lo hace de una manera irónica, que se separa de la escena romántica que le postuló a su interlocutor: libre, quiero estar libre, recorrerlo todo o mirarlo en la televisión. 
La libertad se presenta de una manera dual entonces: se la encuentra a partir del recorrido (quizás a partir del trazo del camino o la huida) y se la celebra desde un lugar impasible y pasatista como el de la televisión, en el que el recorrido es mediatizado y construido enajenadamente. El ideario de lo libre, además, se muestra como un trofeo que permite separarse de otro que vive con intensidad sus valores y luchas. La libertad remarca una constancia de escape y se torna como valor que debe permitir una independencia en el accionar: huyo, si me gritás yo huyo. No creo en tu pelea, yo solo quiero libertad hasta para escaparme.

En esta estrofa, el destinatario se encuentra construido de otro modo, debido a que no expone una situación positiva y de alegría. El interlocutor que se postula podría diferir de la segunda persona destacada anteriormente (enunciada desde la afectuosidad) y, por esto mismo, se articula un discurso de tintes negativos, que no logra motivar a la primera persona. Este receptor actual se identifica con un espacio de reclamo y violencia (huyo, si me gritás yo huyo), pero también se vincula con cierta simulación y fingimiento (no creo en tu pelea).

En virtud de ello, el hablante propone una estrategia de individualidad que se separa aún más del romanticismo recreado en el enunciado previo y destaca una situación de soledad buscada en la que se desata y relaja. La libertad es construida como una significación primordial y un bien de utilidad para resguardar inclusive en etapas de evasión o naufragio: yo solo quiero libertad hasta para escapar.

"Quiero, hacer lo que yo quiero, ser nada de nada, tirado todo el día, imaginarme fuera para todos".

En consecuencia, la historia subraya una construcción de libertad individual, en función de un desenvolvimiento independiente, que evite ataduras y compañías. Es decir, un acto en el cual es posible establecer una instancia de quietud y alejamiento, y también una opción de vida para evadirse de conflictos y nociones activas movilizantes. La libertad, de este modo, puede congregar nociones de pereza e imaginación con un único propósito: tomar decisiones sin ninguna consideración sobre las consecuencias.

En sintonía con esto, el hablante procura sentirse libre para encontrar refugio, para huir de cualquier situación o para evitar la memoria. En este sentido, el desencanto y la despreocupación propia se enlaza también con un fuerte individualismo que roza cierta 
crueldad: "Libre, olvidarme del pasado estar obsesionado por la maldad y la estupidez".

En simultáneo, el hablante lleva al límite su concepción de libertad, tematizada desde el reiterado individualismo, con muestras llanas de decisiones personales y exceso de sarcasmo: siempre ser dueño de mi tiempo para suicidarme o para espiarte cuando te cambies o adorarte un poquito. La construcción de libertad se resuelve desde una situación que torna circular la independencia y que muestra opciones de encierro en un marco de fraguada libertad: libre o dentro de una jaula libre todo el tiempo, ya así cuando quiera, así cuando quiera llegue el fin.

La libertad funciona como acto para escapar y también para mirar la televisión. Es una libertad múltiple que, sin embargo, no parece sentirse de un modo completo porque no se puede evitar la presencia de la jaula que agrupa a todos los sujetos. Por ende, la libertad está vista desde una perspectiva irónica y distanciada: el yo de la lírica solicita libertad, desea estar libre, pero no cree en esa libertad y la construye de una manera condicionada y conclusiva.

\subsubsection{Me veo en la jaula}

"Espirales" Don Cornelio (1988)

La agrupación Don Cornelio y La Zona grabó su primer disco de título homónimo en el año 1987, bajo la producción de Andrés Calamaro. Si bien es una banda que duró solo tres años, vale decir que alcanzaron el éxito y la repercusión radial gracias a la difusión del tema "Ella Vendrá" y, en menor medida, por la rotación de "El rosario en el muro" $" 55$.

La música de Don Cornelio y la Zona se destacó por tener la mixtura de sonidos new wave y aplicaciones estéticas propias del post-punk reinante en la escena inglesa y estadounidense. Las instrumentaciones, por su parte, demostraban situaciones musicalmente sombrías y proponían líricas endebles que se apropiaban de un clima de época incierto y desengañado.

En 1988 editaron su segundo álbum, titulado Patria o muerte, y se renombraron como grupo, denominándose simplemente Don Cornelio (dejando "la zona" oculta en el

\footnotetext{
${ }^{55}$ Esta lírica se analizará en el siguiente capítulo.
} 
tiempo). Esta obra posicionó a la banda y también significó la conclusión de su breve historia. El disco abordaba enunciaciones urbanas (lindantes con la metáfora y las disrupciones literarias) y sostenía un rock eléctrico, visceral y de complejidad sonora. De acuerdo con las consideraciones de la crítica especializada en el rock vernáculo, el disco simbolizó un ataúd para las canciones con estribillos pegadizos y populares propios de las bandas pop o post-punk del rock argentino de los ochenta. De hecho, tanto el primer disco de Don Cornelio como el segundo manifiestan con naturalidad el dramatismo y la inquietante algarabía conseguida por el advenimiento democrático:

(Patria o muerte) Es la mejor banda de sonido de fines de los ochenta, cuando la primavera alfonsinista y el poptimismo de Los Twist y Sueter había quedado atrás y el gobierno radical empezaba a ser hackeado por los levantamientos militares, las huelgas sindicales y la aceleración de la inflación" (Andrade, 2009: 177).

Este material provocó un corte en la escalada comercial y de proposición bailable postulada por Don Cornelio. El concepto y el título del segundo disco expusieron una vanguardia de provocación e ironía en un contexto post-dictatorial y de democracia restringida o de baja intensidad. Por ello, Pandolfo se encargó de ampliar la polémica, aún tiempo después de la edición del disco: "Era un chiste de humor negro sobre el lema que tenían los Montoneros y la Triple A, enemigos que se terminaron matando y destruyeron nuestra cultura" (Schanton, 1999).

En este sentido, "Espirales" es la lírica que da inicio al disco Patria o Muerte y que se encuentra atravesada, desde su estructura enunciativa y metafórica, por un contexto intenso o, por lo menos, urgente. En consecuencia, la elección intencional y su análisis aproximativo-exploratorio se configuran a partir de las nociones complejas de libertad o de liberación que propone la canción.

"Espirales" señala una lejanía desde sus inicios, que se marca en el tiempo y que plantea una inquietud en torno a una acción que se aprecia cotidiana e insignificante: Así, se prevé una sensación negativa en esa acción que se advierte desde la menudencia porque promueve una negativa que vincula los sentimientos con una instancia deficiente, insatisfactoria y descontenta: hace tanto tiempo que quiero llegar a tocarme la cabeza sin sentirme mal".

En la enunciación siguiente, asimismo, el hablante expone un panorama ciertamente desesperanzador. La consideración sobre la jaula se postula desde un rigor penoso que 
arrastra al yo de la lírica y lo hunde en su propia carencia, en sus sentimientos más íntimos y en sus temores más primales: me veo en la jaula Miedo animal de seguir acá, en la calle.

La continuidad entonces, se vincula con una presencia que se amplifica al aclararla, debido a que el adverbio de lugar (acá) señala un espacio particular (la calle) que en la escena podría significar un sitio de ambivalencias negativas: (miedo... acá ... calle). La lejanía que se plantea en el inicio de la lírica (hace tiempo) se contrapone o, al menos, se interpone a una cercanía presencial, identificada con un escape, un punto de huida o un foco de evasión. En este aspecto, el hablante subraya una rotura y un lugar que desplaza los objetos hacia el vacío o directamente hacia el piso. Si bien la salida es cercana, no hay objetos que puedan acompañar, pues lo material que podría atesorarse está abandonado, quebrantado, sin significación.

“Está cerca la salida. Están rotos los bolsillos.

Estoy dentro de ese brillo que me llevará...".

Sin embargo, no se advierten impedimentos para el yo enunciador porque se verifica una particularidad que lo podría conducir a esa salida o que, entre tanto, podría llevarlo a algún sitio incierto y sin relato. No se destaca el lugar de destino, no obstante, los tres puntos suspensivos permiten instaurar una idea de continuidad que debe ser completada y considerada por el lector-escucha-espectador que entiende a esa lírica como un camino de construcción, de comunicación y de acompañamiento.

Ante esto, conviene resaltar que el tiempo verbal en presente juega un rol fundamental en esta estrofa porque se marca un desplazamiento que vierte tres aspectos correspondientes: existe un lugar que está cerca, luego hay bolsillos que están rotos y un hablante que está envuelto y atemperado por algún tipo de centelleo: estoy dentro de ese brillo que me llevará. El movimiento, por tanto, expresa tres estados (está, están, estoy) y el escenario se conmueve a partir de un presente con incidencia subjetiva y cercana.

El hablante se muestra activo en este aspecto y toma un rol fundamental que lo muestra desde un lugar de dador imperativo. Así, la lírica toma un tenor connotativo que plantea un campo semántico de artesanía que parecería demandar un escenario aislado y de creación imaginaria en comparación con aquel yo enjaulado, con miedo y cercano a la salida. 


\section{"Voy a repartir entre las manos de marfil piezas de arcilla que pulí. Vamos espirales, reventemos como un cono".}

El hecho de pulir y de trabajar la arcilla atraviesa un simbolismo de artesanía (hasta originaria) y una actividad sobresaliente por parte del hablante. Sobre todo, desde la arenga que indica una marcha y una detonación en plural: vamos espirales, reventemos como un cono. El camino es de destrucción porque se pule y se reparten piezas con el objeto de reventar (estallar, inmolar, detonar). La forma de esa explosión o de ese reventar coincide con la representación de un cono, pero también de un espiral (o de los espirales para ser específicos). Los espirales, por consiguiente, destacan un profundo estallido que desde el aire revienta y se encona: se podría advertir una curva que da indefinidamente vueltas alrededor de un punto y se aleja más en cada una de ellas.

\section{"Hace tanto frío para respirar.}

Si me suelto la cabeza romperé a brillar".

En la primera estrofa se postulaba un espacio de lejanía que en el actual caso se modifica y confiesa un estado de opresión que no permite vivir y que se muestra imperturbable para el cuerpo humano: hace tanto frio para respirar. En este detalle, se unifican las anteriores estrofas y se retoma la obsesión sensible que impide tocar la cabeza, aunque en este instancia se intenta quitar la misma del cuerpo y sucumbir ante ese brillo desconocido que tanto anhela el yo de la lírica. El acto es de especulación y también propone una expresión de deseo: si me suelto la cabeza, romperé a brillar.

Igualmente, se verifica una creencia que se efectiviza a partir del deseo de escape que no retoma esa cercanía planteada en la segunda estrofa, sino que confía en el recuerdo de otro ser o en la imagen que brindan los propios ojos de ese interlocutor que parece no estar en la situación de enunciación.

"Creo que mi amiga tiene cielo en los ojos.

Si vuelo hacia adentro, llegaré al mar".

Dicha amistad se promueve a partir de la lectura de ojos y de la intención de ver 
reflejados los componentes visibles del espacio en los ojos de otra persona. Ese impacto conmueve al hablante de un modo particular, lo empuja a volar, a incluirse en el interior del otro y alcanzar un acto de inmersión.

El mar, tanto como el cielo, el brillo, los ojos y el vuelo, se erigen conceptualmente desde un lugar positivo y ansiado. La algarabía de la perfección, por cierto, se exhibe a partir de esas tematizaciones en la propia calle y en las jaulas que atormentan al hablante. Los espirales, en tanto, podrían exaltar la conexión con ese bienestar celestino-libertario que pretende contactar el yo de la lírica: al reventar, estalla, se encona y entabla relación con un cielo que, por lo pronto, puede advertir en los ojos de otro ser.

\subsection{3. ¿Adónde morimos hoy?}

"Enjaulados"

Fricción (1988)

Fricción fue un grupo comandado por el guitarrista Richard Coleman que se formó en 1985 y que estaba integrada por artistas conocidos en el ambiente de la cultura rock local de la época: Gustavo Cerati (líder de Soda Stereo), Celsa Mel Gowland (corista y vocalista en Sueter y Metrópoli, respectivamente), Christian Basso (integrante de Clap y luego de La Portuaria), Gonzalo Palacios (saxofonista que participó en Los Twist y Patricio Rey y Sus Redonditos de Ricota) y Fernando Samalea (integrante de Instrucción Cívica, entre otras agrupaciones y/o solistas).

El álbum debut, editado en 1986, se denominó Consumación o Consumo y es, tal vez, el más recordado de la banda porque contiene canciones que rotaron espaciadamente en las radios como "Perdiendo el Contacto", "Autos Sobre Mi Cama" o "Arquitectura Moderna": "Era una música muy distinta, era la banda nueva, nadie sonaba como nosotros. Estaba todo buenísimo, pero Fricción era un grupo que en realidad no existía: era la base de Clap, con el cantante de Soda Stereo y yo" (Andrade, 2009).

En 1988, Fricción renovó su formación, reforzó el liderazgo de Richard Coleman y grabó su segundo disco, titulado Para Terminar. El disco tuvo una rotación moderada gracias a la versión castellanizada del tema "Héroes" de David Bowie y la canción "Enjaulados" (que tuvo un fugaz éxito en las discotecas de las grandes urbes de la Argentina: Rosario, Córdoba, Gran Buenos Aires y la ciudad de Buenos Aires): “'Para terminar' ¿qué puede ser? ¿Para terminar con la vida de uno mientras grabás? ¿Para 
terminar con tu pareja, con tu relación familiar? Este disco se hizo para terminar. Terminar con una cosa y empezar con otra" (Marchi, 1988).

En este sentido, el álbum significó el final de la banda debido al poco interés de la discográfica en su difusión y, sobre todo, al cansancio interno de la banda. No obstante, es el trabajo más oscuro e irónico de la banda. En este sentido, el trazo lírico de Coleman se encuentra más presente que en Consumación y Consumo debido a la producción en solitario que tuvo el disco (con una participación menor, pero intensa de Gustavo Cerati).

La canción "Enjaulados" se ubica como la quinta pista del disco Para terminar. El discurso de la lírica propone un signo de urgencia y de desplazamiento en virtud de conectar y encontrar una salida. La historia que se propone se vincula con decisiones y modos de vida que se advierten a partir de los movimientos de un hablante primordial y un interlocutor que acompaña las peripecias.

"Ya tenés tu equipo de sombra, y un poco de metal para desplazarte, vas a conectarte para salir".

Desde el inicio, el yo de la lírica se dirige a una segunda persona que está dispuesta a salir e integrarse (conectarte) con el exterior de un modo reiterativo: las participaciones con el mundo se dan a partir de sus estadías en las jaulas (que parecen ser urbanas y pueden variar).

La virtud identitaria de la vestimenta, en este caso, se destaca de un modo primordial y alude, quizás, a un de estética dark de finales de la década del ochenta que comparte gustos estéticos, musicales y culturales con los integrantes de dicha subcultura (ya tenés tu equipo de sombra). En este caso, la sombra se relaciona con una apariencia y un gusto por el sonido oscuro (trajes negros, maquillaje para resaltar palidez en el rostro o pintalabios negro o rojo).

El segundo estribillo presenta un enunciado corto, conciso y a la vez expectante: ¿adónde morimos hoy? Por lo tanto, el discurso que antes se dirigía a una única persona se pluraliza e incluye al hablante en el instante en el que se pone de manifiesto una interrogación que podría no tener respuesta.

El interrogante ¿adónde morimos hoy? remite a una visita en la que se simboliza el final del viaje o de la salida. Es, en sí mismo, una muerte con participación activa. Es una 
pretensión de esparcimiento que, si se tiene en cuenta el desarrollo de la lírica, se relaciona, preferentemente, con una salida nocturna y una visita a un sitio bailable en el que la personalidad se difumina y se homogeneiza.

"Podemos aturdirnos hasta disolvernos, en el café moderno y luego partir. Abriendo surcos, surcos de neón".

Por eso mismo, el tercer estribillo continúa la pluralización y marca un punto de olvido del ser y de disolución del propio yo (podemos aturdirnos hasta disolvernos). Los verbos aturdir y disolver proponen una conjunción necesaria para estos jóvenes que buscan escapar, divertir y salir: se busca encontrar una perturbación de los sentidos y, de la misma forma, fragmentar y envolver su existencia en un ruido extremo. La partida entonces, se torna esencial para comprender nuevos horizontes que permitan reconocer grietas y experimentaciones que iluminen su presencia en la calle y el sitio bailable (abriendo surcos de neón).

“Buscando otra celda confortable, adónde bailar, enjaulados.

Sudando el maquillaje, bailando enjaulados, enjaulados..."

No obstante ello, la libertad se reconoce de un modo irónico, ya que se advierte una situación de opresión sugestiva, detectada e ironizada (buscando otra celda confortable). La identidad gótica o dark, a partir de ello, sobrevive en una jaula, en virtud de un baile desconsolado y la comodidad falsa. El baile, por su parte, se disfruta, pero se percibe desde el encierro (enjaulados) y hasta de un modo apasionado y encendido (sudando el maquillaje, bailando enjaulados).

"Ya cambiaste mil veces de forma, alterando tu expresión, y cambias el panorama, con cada nueva canción”"

En el cuarto estribillo, el yo de la lírica vuelve al inicio, olvida la pluralización y destaca nuevamente la premura, la transformación, la alteración y las distinciones que tiene el interlocutor en un momento de baile y dispersión. La liberación, en este sentido, se coteja a partir del baile: ya cambiaste mil veces de forma y cambias el panorama con cada nueva canción. Se pretende así dejar constancia de una diversión efímera y 
momentánea en la que el interlocutor vive cada canción como si fuera su última participación. Se subraya, de este modo, una identidad transformadora constante, pero a la vez desconsolada porque el baile se desenvuelve en una celda confortable.

\section{“Oigo un famélico, rabioso perro eléctrico, babeando por la radio detergente mental. ¡Apágalo, está lavando tu prisión!} ¡Detergente mental!’

El último estribillo de la lírica plantea una situación surrealista en la que irrumpe la presencia sonora de un animal con energía asfixiante: oigo a un famélico rabioso perro eléctrico babeando por la radio, detergente mental. El campo semántico que se expone en este caso, enlaza situaciones negativas en torno a una figura opresiva hambrienta, potente, exaltada y tóxica (famélica, rabiosa, eléctrica).

El denominado detergente mental se coloca desde una carga de valor negativa porque el hablante (que domina plenamente todo el estribillo final), solicita exaltadamente la cancelación del audio (¡apágalo!) y advierte una situación de limpieza que también se presume desde una cuestión desaprobada (jestá lavando tu prisión!). La prisión, de esta manera, se vive como una situación individual, en la cual el hablante se refugia de un modo cáustico y resignado.

Se ofrece así una pequeña disidencia porque los interlocutores parecen tolerar desconsoladamente la dominación (la celda, la jaula, la prisión) a partir del baile y el mundo sonoro, pero no soportan las participaciones habladas y/o conversadas a los gritos que por la radio pueden criticar las prácticas o las actividades de los jóvenes.

Hay una resistencia defensiva que impide la comunicación con los dueños de la palabra por radio (que podría referir a una palabra legítima, institucional y/o adulta) y que sólo respeta la convivencia a partir de la música y el baile. Este ámbito, por lo tanto, defiende su libertad de baja intensidad y se opone a las diatribas o los mandamientos que puedan surgir de la radio o de los gruñidos de los perros eléctricos que buscan limpiar las mentes de los libres-divertidos (;detergente mental!). 


\subsubsection{Atrapados por la misma red}

"Héroes Anónimos"

Metrópoli (1986)

La irrupción de Metrópoli en la escena pop de mediados de los 80 resultó importante por dos cuestiones singulares: por un lado, se trataba de un conjunto liderado por una mujer (al igual que La Torre) y por otro, planteaba una propuesta de pop-rock suave y con líricas que rozaban, quizás, cierto realismo mágico y onírico. En este sentido, la banda formada por el guitarrista Ulises Butrón y la cantante Isabel de Sebastián forjó una identidad que, si bien no fue duradera si se tiene en cuenta el corto período de actividad, supo editar dos trabajos muy bien elaborados: Cemento de contacto en 1985 y Viaje al más acá en 1986.

El dúo tomó relevancia masiva luego de la edición de su segundo y último disco, que consiguió una circulación rápida en los medios de comunicación (sobre todo en la radio) a partir de la difusión de "Héroes anónimos". Dicha canción es la más popular del grupo y se encuentra ubicada como la primera pista de Viaje al más acá. Este álbum, por cierto, representó un avance sonoro y lírico para la banda, y por esto mismo, de Sebastián se encargó de señalarlo en su momento: "El material está cargado de romanticismo, pero no en el sentido sensiblero de la palabra, sino que aquí se alude a una fuerte cuestión idealista (...) Nosotros queremos con "Viaje" ir capturando toda la realidad a través de la poesía" (Mercuri, 1986: 11).

La lírica de "Héroes Anónimos" parte de la enunciación de una primera persona del plural, dictada por un nosotros inclusivo que refiere a una situación defensiva y de resistencia. Se advierte así una situación de encerramiento (estamos atrapados por la misma red), que implica un destino circular y retorcido (viajando por un laberinto) y de padecimiento frente a un derrumbe que atosiga y coarta libertades (estamos sosteniendo una pared).

\section{"Estamos atrapados en la misma red. Viajando por un}

laberinto. Estamos sosteniendo una pared.

Por favor, no las dejes caer". 
En función de ello, el hablante refuerza su discurso en virtud de la acción y la actitud de su interlocutor (por favor, no la dejes caer). Es a partir de ello que la primera persona del singular domina la articulación del discurso y la puesta en escena de la lírica:

“Ceferino no me escucha más ¿Adónde fue la Madre

María? Aunque no crea en la casualidad,

Sueño con Loterías”.

Particularmente, en este enunciado se aprecia la intervención de una primera persona que se muestra en un momento de resignación pendular. Si bien el hablante reconoce una situación compleja en torno a las creencias (Ceferino no me escucha más ¿adónde fue la Madre María?), también resalta una mínima fe en torno al escenario secular (sueño con loterías). En consecuencia, los enunciados diagraman una articulación de periplos singulares que remiten a aspectos cotidianos de la vida: el refugio en la religión, la situación de no ser amparado por la lógica divina y la elección del azar como método para salvaguardar la propia existencia.

Como señala la periodista Adriana Mercuri, estos aspectos exponen un derrotero de vivencias que intentan rescatar, a través de la poesía, el sutil encanto y la cruda realidad de la mitología metropolitana, viendo desde lejos la cercanía del propio interior (1986: $11)$.

\section{“Todos somos Héroes Anónimos, guerreros de este \\ lugar, peleando con el corazón, combatiendo tanta soledad".}

La enunciación de la lírica, entonces, prosigue en relación con una reflexión primordial que tiene que ver con una totalidad y la postulación de un nosotros inclusivo que señala la fuerza del anonimato.

"Me bombardean otra vez, vuelvo a construir mi

casa. Como una fuerza del más allá, encuentro en tu mirada". 
El locutor expone un lugar de resistencia, de orientación voluntativa y con destaque constructivo (me bombardean otra vez, vuelvo a construir mi casa). Por esta razón, hacia el final de la lírica se emplea una operación discursiva que diagrama un cuadro de esperanzas y expectativas en un interlocutor, que a su vez es reforzado por una idea de acompañamiento y contención: como una fuerza del más allá, encuentro en tu mirada.

\subsubsection{Temiendo un nuevo dolor}

"Acción y reacción"

La Sobrecarga (1986)

La Sobrecarga es una de las pocas agrupaciones del interior de Buenos Aires que tuvieron un reconocimiento en el ambiente de rock argentino durante la década del 80 (son oriundos de Trenque Lauquen). Por esto mismo, y en sintonía con las líricas y las sonoridades propuestas por Los Pillos y Don Cornelio y la Zona, se convirtió en una de las bandas más importantes de la escena post-punk o dark underground de la segunda mitad de la década.

En este sentido, la producción del disco Sentidos congelados, editado en 1986, tuvo una distinción notable para una banda underground de los 80 porque fue grabado sin un productor artístico de renombre. Si bien el álbum obtuvo repercusiones modestas, La Sobrecarga tuvo una alta rotación en las radios a partir de la difusión de la canción más conocida de su historia: “Conexión París”. Esta expansión, de hecho, les permitió sonar modestamente en las radios de Chile o Perú, y también contribuyó a su participación como teloneros de la banda británica The Cure en sus caóticos dos recitales realizados en el Estadio de Ferrocarril Oeste, en 1987.

La canción “Acción y reacción” es la novena pista del disco debut Sentidos Congelados.

En lo que concierne al discurso articulado en la lírica, se aprecia un empleo predominante de la segunda persona del singular, que resulta interpelada y puesta en crisis a partir de los comentarios vertidos por el locutor. En este aspecto, la primera persona del plural participa desde una instancia preponderante porque abraza una perspectiva inclusiva.

"Oye, no cambies el ritmo de hoy.

Vamos corriendo sin dirección, estamos buscando una nueva visión”. 
Por otra parte, el deíctico temporal trabaja fuertemente desde la demarcación de un hoy, que se presenta dinámico, inquieto $\mathrm{y}$ en virtud del ejercicio. El hablante señala un compás diferente que abre un paradigma de escape y advierte una vida sin temor (el ritmo de hoy). Así, se sostiene la presencia de un dolor cercano, previo y quizás colectivo: hay algo oculto en el ritmo de hoy. Vivir temiendo un nuevo dolor aumenta el tedio.

Siguiendo esta línea, el temor parece adormecer y no permitir la liberación: incrementa el enfado y la quietud (aumenta el tedio). Frente a esto, el hablante resalta que el ritmo debe mantenerse y contemplar también sus zonas atesoradas que amplifican la libertad (una nueva visión). Se advierte entonces que la libertad se encuentra determinada por la acción, tomando en consideración la operación propia de una vida que debe ser aprehendida para distinguir y ganar experiencia: "Cuando reaccione, cuando reacciones".

De la misma manera, la reacción confluye hacia una mirada conducente con un mundo contextual determinado. El empleo del hoy subraya una instancia enérgica, en la que la temporalidad cobra importancia porque se desconoce cuán relativa puede ser la perdida del ritmo. En efecto, no sólo se acentúa la aplicación temporal (hoy), sino también se advierte una exigencia que recae directamente en el interlocutor: se le solicita que no modifique una cadencia sobresaliente y su consecuente obstinación premeditada (no cambies el ritmo).

El compás se mantiene en el movimiento y el ritmo y, en virtud de ello, la libertad no se vincula con la quietud, sino con la búsqueda, la tendencia y la manutención de un ritmo. El hablante señala un punto de partida, que abre un panorama de reacción y enlaza una fuerza igual y contraria a la que sobre él actúa. Como sostienen Quintana y de la Puente, en "Acción y reacción" se condensan ideas movilizadotas y estimulantes ante un presente de tensión: “la 'búsqueda de una nueva visión' (movimiento y ojos); 'temiendo un nuevo dolor' (una toma de conciencia que pone en peligro ese dinamismo) y que a la vez 'aumenta el tedio"” (1996: 193). 


\subsection{6. ¿Cómo podremos sobrevivir?}

"Prófugos"

Soda Stereo (1986)

La canción "Prófugos" está ubicada como tercera pista del recordado y exitoso tercer disco de Soda Stereo: Signos. El álbum patentó el alcance masivo del grupo y profundizó su éxito a nivel latinoamericano tras la circulación de distintos clásicos históricos del rock argentino: "Persiana Americana", "Signos", "El Rito", "No Existes" y "Prófugos".

En esta última canción, se manifiesta una mutación de Soda Stereo como estela artística, puesto que se aparta del optimismo divertido planteado en "Dietético", la otra lírica de la banda que integra el corpus analítico de este trabajo doctoral. De este modo, se asesta una cara distintiva en plena democracia y un despliegue de orientación nihilista, de poética sórdida y escapista.

En esta lírica, se expone entonces la presencia de una primera persona que dirige el relato, refiriéndose a la segunda persona de un modo aleatorio y remitiéndose a la primera persona del plural en el momento de remarcar las instancias libertarias:

Prófugos comienza hablando de una complicidad compartida, de una culpa dividida en partes iguales. Obviamente la responsabilidad del funcionamiento de la pareja responde a ambos integrantes (...) Imposibilitando así el marginamiento, e incluyendo el estatismo como una forma más de tomar partido (Quintana y de la Puente, 1996: 199).

A partir de ello, la lírica aborda connivencias plurales en torno a la búsqueda de libertad, pero se remarca la individualidad en el momento de reafirmar un estado de seguridad y de escape. La huida parece apreciar un sentido, y el amor, entendido como estado de ensoñación y de sostenimiento, ofrece una presencia relevante para la búsqueda de libertad. La complicidad, por ello mismo, parece reforzar levemente una unidad.

"Somos cómplices los dos. Al menos, sé que huyo porque amo. Necesito distensión.

Estar asi despierto es un delirio de condenados". 
Frente a esto, el hablante vivencia un presente de tensión, de agotamiento, de nocturnidad o de insomnio que provoca preocupaciones. Sobre este punto, y como efecto secundario, el acto de agotamiento que muestra el hablante rescata un todo que, como acto destrucción, anuncia una predilección por el despego y desagrado:

"Como un efecto residual, yo siempre tomare el desvío.

Tus ojos nunca mentirán, pero ese ruido blanco es una alarma en mis oídos".

El locutor demuestra confianza en su interlocutor, y subraya así que la persecución de libertad los incumbe a ambos, aunque sólo uno parezca estar dispuesto a escapar de una realidad abrasiva y amenazante: yo siempre tomaré el desvío. Del mismo modo, el interlocutor es postulado de un modo creíble e inocente que, no obstante, no logra abstraer al yo de la lírica, que sufre y padece las alarmas de la vida cotidiana: pero ese ruido blanco es una alarma en mis oídos.

Por esta razón, en el estribillo se remarca un reproche en función de la persecución de la libertad en la huída, en la ausencia de afecto y en el destino desertor. El interlocutor propone, posiblemente, una instancia más sedentaria que no conforma ni reconforta al locutor: no seas tan cruel, no busques más pretextos. Siempre seremos prófugos.

En consecuencia, la lírica toma un viraje luego de este reclamo porque se aplica una idea de convencimiento por sobre el interlocutor. La estrategia discursiva aborda una instancia argumentativa y el hablante, que en distintos momentos se expone desde una instancia de individualidad, apela a la complicidad del plural como demostración enloquecedora:

"No tenemos dónde ir, somos como un área devastada.

Carreteras sin sentido,

Religiones sin motivo: ¿Cómo podremos sobrevivir?”

El yo emplea la figura del nosotros para exagerar o remarcar la situación de huida. Así, la mirada se torna extrema y la libertad se expone solo a partir de la huída que, pese a las esperanzas, se vuelve cada vez más imposible: no tenemos dónde ir, somos como un área devastada. 
Los enunciados son certeros y asertivos: se refuerza la falta de perspectiva tras pensar en huir y reconocer la imposibilidad de ejercer dicho escape: no tenemos dónde ir; y se señala también la inviabilidad de un camino práctico o de fe que pueda reconfigurar un sentido o motivo: carreteras sin sentido, religiones sin motivo. Continuando esta idea, el último enunciado concluye en un interrogante que persuade directamente al interlocutor, luego de la argumentación apocalíptica y quizás enloquecedora: ¿cómo podremos sobrevivir?

\subsubsection{Bajo un cielo tan igual}

"Soy donde voy"

GIT (1985)

GIT fue un grupo formado en 1984 e integrado por tres artistas de amplio recorrido en el rock argentino: Alfredo Toth, Pablo Guyot y Willi Iturri. Si bien estos músicos ya eran reconocidos en la escena local, la conformación de trío la efectuaron al participar como banda estable de Raúl Porchetto durante los años 1979 y 1982 y de Charly García durante el período 1983-1984.

El disco debut de GIT, titulado con el nombre de la banda, fue producido por García y también se editó en 1984. La placa contenía canciones que obtuvieron una alta rotación en las radios y bailes de la época, entre las que se destacaban "La calle es su lugar (Ana)", "Acaba de nacer" y "Viento loco".

El segundo álbum, denominado GIT Volumen 2, fue publicado en 1985 y producido por el ex líder la banda Arco Iris, Gustavo Santaolalla. El disco fue uno de los más reconocidos de la banda porque simbolizó el puntapié inicial para que GIT comenzara a tener un alcance masivo en la totalidad del país y en otros de Latinoamérica. El material, también conocido como "el álbum negro de GIT", alcanzó cifras altas en ventas a partir de la inclusión de dos canciones clásicas de la banda: "Siempre fuiste mi amor" y "Aire de Todos".

La canción "Soy donde voy" es la última pieza de GIT Volumen 2. La lírica presenta a una primera persona que se posiciona como la principal referencia y una segunda persona que es postulada como un receptor válido para postular deseos. En función de ello, la deixis personal comparte un congruente compartimento con el indicio de deixis espacial (allá) y temporal (hoy). Se advierte así un hablante que se muestra de un modo 
dinámico e inquieto, con intenciones de ejercer su libertad en movimiento, exhibiendo su voluntad de expresión y de alcanzar al máximo el empleo de la independencia:

“Abriendo puertas y saltando para allá. Lleno de tanto aire y tanto que contar. Y quise más, más que respirar.

Quise tantas cosas más”.

Sobre este punto, la aplicación del movimiento persiste y anuncia una construcción de hablante preocupado por reafirmar su autonomía y exponer su ambición. La irreverencia está vinculada con la urgencia y la voluntad de estar en movimiento con el propósito de poner en acción el cuerpo: abriendo puertas y saltando para allá. En consecuencia, la estrategia discursiva expone a un hablante que exacerba sus posibilidades y sus intenciones de vida: lleno de aire y tanto que contar. Asimismo, se resalta un atrevimiento preponderante que exhibe ambiciones y deseos en pos de la concreción de los desplazamientos: y quise más, más que respirar. Quise tantas cosas más.

"Pinté mi cara y seca, y canto y lo demás.

Crucé Bolivia y fui al polo a patinar.

Y quise más, más que nada más Quise tantas cosas más”.

De esta manera, el hablante remarca que su existencia se confirma en el camino y su puesta en libertad se vincula con el tránsito y el proceso de exponer su independencia en cada lugar que visita o que espera visitar: crucé Bolivia y fui al polo. Del mismo modo, se reitera la exposición de una individualidad anhelosa, que se configura a partir de un andar propio, de despliegue particular y de conocimiento privativo: pinté mi cara y seca, quise más, más que nada más.

"Soy donde voy. Voy como voy.

Soy donde estoy. Hoy donde hoy”.

La referencia temporal, a partir de ello, muestra un presente cambiante (hoy donde hoy), y las posibilidades manifiestan una igualdad de condiciones en que no aprecia diferencias: la libertad se muestra a la guarda de un viaje o un nuevo desplazamiento (voy como voy). 


\section{"Libertad pronto bajo un cielo tan igual.}

Que de aburrido solo quise caminar.

Y quise más, más si mucho más.

Solo quise tantas cosas más”.

El desplazamiento, por tanto, aplica una idea de sorpresa y también de actualidad y vigencia. La libertad es construida como una necesidad en un universo que no es cambiante, sino modificable a partir de las decisiones de los propios sujetos (libertad bajo un cielo tan igual). El hablante parece no encontrar disfrute en la quietud y por esto mismo sale del aburrimiento en el camino, en el andar, pretendiendo alcanzar un máximo de destinos (que de aburrido solo quise caminar).

\section{"Nunca podrás creer a donde estoy,}

No te imaginas de a donde soy".

En la última estrofa, el locutor refiere directamente a su interlocutor, utilizando una estrategia para convencerlo, para generar un incentivo y una estimulación de viaje. Por esta razón, se expone una definición del quehacer individualista al recalcar la imposibilidad de imaginar en conjunto lo que puede hacer o ser ese otro. En este sentido, es posible pensar que el hablante busca afectar al receptor desde la determinación de un desconcierto y a partir de una indomable puesta en común de la búsqueda libertaria.

\subsubsection{La cuota de mi libertad}

"Ocho Ríos"

Los Pericos (1988)

Los Pericos es una banda fundada en 1986, considerada como una de las primeras en desarrollar una estética reggae y pop a nivel latinoamericano a partir de la sonoridad de sus canciones, la vestimenta y el discurso presente en las líricas. Su álbum debut, titulado El ritual de la banana, producido por Javier Calamaro y editado en 1987, significó un despegue vertiginoso para el grupo a causa de tres factores importantes: en primer lugar, lo novedoso de la propuesta musical para el ambiente cultural argentino, 
en segundo orden, por la idea de cantar sus canciones en el idioma inglés (esto se debe en gran parte a la influencia de Sumo); y en tercer término, por la alta rotación de sus primeros cortes de difusión: "Jamaica Reggae”, “Ojos de ciudad”, "Nada que perder" y "El ritual de la banana".

A través de Los Pericos muchos jóvenes comenzaron a conocer masivamente la estética reggae y a reconocer en el músico jamaiquino Bob Marley una referencia de resistencia, lucha y conciencia urbana. Por esto mismo, el grupo cobró relevancia internacional y logró que su segundo disco fuera producido por el cantante de Os Paralamas do Sucesso, Herbert Vianna. El álbum, titulado King Kong y editado en 1988, no replicó el camino de éxito de la primera obra, pero logró cierta presencia en la radio y la televisión a partir de las canciones "Fronteras en América", "Che Nena” y "Ocho Ríos".

"Ocho ríos" fue una de las canciones más destacadas de dicho álbum porque presenta una musicalidad suave y un relato lírico construido de un modo paulatino que ofrece un escenario muy natural con el objeto de exponer una situación de relajo y descanso: $y$ en Ocho Ríos Te escribo de Ocho Ríos.

La lírica comienza con una continuidad que es enfatizada por el coordinante $y$, que da cuenta de un desarrollo y de un devenir previo. Por esto mismo, se advierte la presencia de un hablante que se encuentra en un lugar placentero y natural como la ciudad de Ocho Ríos. Este sitio, muy propio del universo reggae, y también turístico por encontrarse en Jamaica, funciona como puerto para escala de cruceros y para barcos que transportan cargas diversas, pero también pasajeros que visitan un paisaje cálido, en compañía del mar y el sol omnipresente. En este contexto, el hablante se encuentra en proceso, escribiendo un mensaje con un destino que aún se desconoce, y que a su vez es preciso porque la narración atraviesa su experiencia en Ocho Ríos.

"Con un cigarro en la piel te escribo.

Con un cigarro en la sien te digo que en ocho ríos, no paso de Ocho Ríos".

En esta estrofa se expone una situación reiterada en la que el hablante se sirve de la presencia del cigarro para dar lugar a su acción de escribirle a ese interlocutor desconocido (te escribo) y decir (te digo) que en ese lugar parece estar paralizado o suspendido (no paso de Ocho Ríos). La ambigüedad que propone este enunciado se explota a partir de la utilización del cigarro que puede señalar una situación de 
sufrimiento (un cigarro encendido marcando la piel y la sien) o de confortabilidad vinculada con el contexto jamaiquino (un cigarrillo de marihuana que, partir de su humo, transita el cuerpo del hablante).

"Se duerme el ángel en mi corazón.

Y este gran sueño no, no tiene dolor.

Me quedo, me quedo para no volver.

Me quedo, me quedo, me quedo”.

Por esto mismo, el locutor da cuenta de una situación confortable en la que se advierte la presencia de otro que lo acompaña, que es calificado como ángel y que se encuentra reposando en el pecho de quien lo enuncia (en mi corazón). En esa escena, ese otro sujeto que se encuentra entre sueños también se halla complacido por la situación y el descanso no parece amenazador ni quejumbroso.

El hablante remarca esa instancia de concordia y describe la profundidad de ese momento (este gran sueño no, no tiene dolor). Del mismo modo, el escenario lo conmueve y le permite actuar de modo reflexivo, destacando su pertenencia en el lugar y su elección de vida. La repetición de esa decisión que incluye continuar viviendo la experiencia de libertad y confortabilidad en "Ocho Ríos" permite que el hablante remarque su vivencia: me quedo, me quedo, para no volver. Me quedo, me quedo, me quedo.

"Con esa marca en la piel te escribo.

Con esa vieja mujer te digo:

en Ocho Ríos, ya soy parte de ocho ríos.

Se duerme el ángel en mi corazón.

Y es gran sueño no tiene nada de dolor".

En esta estrofa se expone la existencia de una herida, una huella o una cicatriz en la piel del hablante, que continúa una escritura con destinatarios desconocidos. Esa marca en la piel que se destaca podría entenderse como una verdadera lesión verificable o como una metáfora de una existencia compleja, con dolores de vida que se reflejan en la experiencia. Asimismo, es posible comprender que el ángel anteriormente enunciado pueda referir a esa vieja mujer que se enfatiza y se señala en virtud de la ausencia de pena y sufrimiento. Sumado a esto, la descripción que realiza el hablante sobre la 
presencia del ángel/vieja mujer refuerza la pertenencia y la integración que tiene con el lugar, a fin de cuentas: ya soy parte de Ocho Ríos.

"Pagué la cuota de mi libertad

Y en ocho ríos..."

Como consideración final, el hablante intenta darle una explicación a ese lugar de confortabilidad y por ello lo destaca como un triunfo que le permite conmemorar una liberación propia: mi libertad. En este aspecto, la libertad es puesta en juego como una ganancia y una riqueza que se corona a partir de la conjugación de la presencia del locutor en el lugar, el acompañamiento que tiene y la influencia del lugar mismo. De esta manera, el hablante demuestra que se encuentra en un momento satisfactorio que, no obstante, no es considerado de un modo perpetuo, sino provisorio y temporal: pagué la cuota de mi libertad.

\subsection{Consideraciones parciales}

\section{Una libertad en tensión: el yo en perspectiva, entre el aislamiento y el escape}

Como se mencionó previamente, las líricas expuestas en este capítulo plantean dos cuestiones fundamentales: por un lado, una noción de encierro (de resignación y de resistencia, según los casos) y por otro, una voluntad de huida y escape hacia otras realidades. De este modo, se configuran inscripciones discursivas de orden individual, que postulan un nuevo código juvenil y también una actitud de transformación en relación con el propio quehacer del rock-pop argentino.

En este sentido, las letras construyen una discursividad de tensión con ciertas prácticas de los ciudadanos y de los jóvenes en particular en un marco democrático. Por esta razón, es posible señalar que el eje del individualismo profundiza un aspecto distintivo en las líricas, puesto que vincula los alcances del placer y la satisfacción en virtud de problematizaciones que intentan comprender la vida urbana y la cotidianeidad juvenil. Así, las modificaciones discursivas propuestas habilitan un campo de disputa con características de fuga y/o escape a través de exploraciones extrovertidas e introvertidas. Del mismo modo, el empleo del nosotros y la noción de grupo o colectivo sirve a los efectos de condensar una persecución de libertad acompañada, pero también cercenada. 
Por tanto, la procuración de una mayor autonomía y de la estimada independencia es articulada desde la individualidad y desde lo colectivo con un objetivo muchas veces desalentador y agonizante. En este aspecto, se pueden visualizar palabras con una carga valorativa negativa o, en tal caso, inquietante: fracaso, miedo, sombra, soledad, tedio, condenados.

Siguiendo esta línea, las letras analizadas también exponen una crítica hacia la fosilización de vida, pero asimismo dan cuenta de las posibilidades de permanecer en un espacio de quietud y estancamiento aún en un contexto de posibilidades libertarias. Por consiguiente, cobra relevancia el rol de los aspectos de la intimidad como tópico que profundiza aún más la derivación de la libertad aislada y/o encerrada.

Se manifiestan entonces, estados y características que generan inquietudes sobre el proceso de aislamiento generado por las distribuciones sociales y los nuevos ejes rectores de la vida: los medios de comunicación y los consumos masivos ("Fotos de una jaula"), la privatización de las acciones colectivas ("Espirales") y las secuencias circulares del encierro en una sociedad pos-dictatorial ("Enjaulados”).

En consonancia, también se advierte un discurso alineado a un diagrama de recambio que planifica la propia vida desde la individualidad y las corporalidades específicas como objetivo de despliegue en sociedad. Así, de esta vertiente se articulan dos temáticas de libertad relacionadas, por un lado, con una poética de esperanza resistente ("Héroes anónimos") y también en estado de alerta (“Acción y reacción”). Del mismo modo, se subraya una enunciación exploratoria que intenta alcanzar renovadas introspecciones ("Ocho ríos"), ubicar otras conmociones ("Soy donde voy”) y advertir también nociones de abandono y huída ("Prófugos"). 


\section{Capítulo IX}

\section{Entre la libertad y el desencanto: claves y pistas de una nueva enunciación}

\subsubsection{Las expectativas truncas}

La segunda mitad del gobierno alfonsinista (1986-1989) constituyó un período de desencanto que sin lugar a dudas impactó fuertemente en las líricas producidas en un marco de cultura rock argentina. Por esto mismo, comenzaron a advertirse distintas modificaciones en relación con los aspectos temáticos y narrativos de las letras, que en otro momento se habían postulado desde una enunciación positiva y optimista. La crisis de la noción democrática y de los aspectos valorables del ser libre se vio reflejada en las líricas del universo del rock-pop argentino.

Si se intenta buscar un motivo primordial, es posible señalar como punta de lanza la caída de popularidad de la administración radical y la consiguiente crisis de confiabilidad vinculada a la conformación de un estado de derechos con efectivas libertades para los habitantes. Al respecto, la sanción de las leyes de Obediencia Debida en 1986 y de Punto Final en 1987 generó un quiebre de expectativas muy fuerte en la sociedad, puntualmente en el público de rock que comenzaba a tener una relación nuevamente tensionante con la policía y la gendarmería en las calles.

Frente a esto, los intereses políticos, sociales y cotidianos de las líricas del rock-pop argentino se orientaron hacia un desencanto que no reconocía ilusiones ni prosperidades en términos globales. Como señala Eduardo Fabregat, hacia 1986 la cultura rock se encontraba a años luz de la alegría imperante del período 1983-1985: "El país, en solo dos años, comprobó que no era tan fácil comer, curar y educar. Era tan fácil limpiar tanta mugre subterránea, que habría que recorrer un largo camino hasta castigar tanto crimen, la negritud y el pesimismo ganaran el horizonte" (2007: 23).

La sensación de alegría y esperanza que había comenzado y se había desarrollado en los primeros tres años tras la asunción de Alfonsín, fue disminuyendo mientras los conflictos militares, económicos y legislativos se incrementaban y se consagraban a partir de la impunidad instituida desde el Estado. El rock acompañó este proceso desde sus distintas perspectivas, primero desde un humor social triunfante y luego desde la postulación del desengaño o del nihilismo sobre la democracia. 
Así, se dejaron de lado las canciones con sonoridades festivas o discursos líricos alborozados, y comenzaron a advertirse nociones de fracaso $y / o$ ausencias de expectativa en relación con la instancia democrática. La cultura rock argentina empezó a modificar sus discursos de inclinación pop en virtud de un nihilismo que celebraba críticamente y reflexionaba sobre el estado de ánimo optimista de los inicios.

En este sentido, se fue operando un cierre de celebración simbólico de ese período fugaz y veloz de 1982-1985: "El rock, que en su vertiente pop lo había festejado, mostró su decepción ante el estado de crisis permanente e hiperinflación, y lo moderno se inflexionó en dark, con un costado más pesimista" (Blanco y Scaricaciottoli 2014: 146). Si bien las temáticas del amor y del sexo aún conservaban su preponderancia discursiva, también podían advertirse nociones distintas que tensionaban los relatos: "por un lado, la desaparición de un amor idealista y todopoderoso, reemplazado por los síntomas tortuoso del crecimiento $\mathrm{y}$, por el otro, el sexo sin los fundamentos 'profundos' que hasta el momento lo habían justificado" (Quintana y De la Puente, 1996: 190).

El contexto de hiperinflación y las conmociones sociales y políticas y culturales sacudió fuertemente el ámbito de la escena rock de argentina. Al respecto, el periodista Juan Manuel Cibeira suma una instancia crítica a este cierre de época y destaca que la finalización estrepitosa del gobierno de Alfonsín desnudó también la "falta de creatividad" del rock durante los últimos dos años de la década del 80: "Esterilidad en las letras, insistencia en la reproducción de modelos sonoros sin ningún contenido original y ausencia de un proyecto ideológico fueron las constantes mostradas por la mayoría de las propuestas" (2014: 237).

De esta manera, la cultura rock argentina profundizó una pronunciación discursiva relacionada con la cultura de lo efímero, acentuando la actualidad del presente, anunciando el deceso del progreso colectivo, los temores de la cotidianeidad, las miradas apocalíptica en torno a la felicidad o el amor y el cierre de ciertas concepciones ideológicas macro, como se mencionó en el capítulo anterior.

\subsubsection{Una temática de resignación y desengaño}

Junto con el anuncio potente de las corrientes posmodernas, la segunda mitad de la década del 80 obtuvo una definición relativista por parte del rock argentino. Por ello, en las líricas comenzaron a advertirse articulaciones fragmentarias y rupturistas que 
obturaban continuidades de relatos o exponían tensiones en torno a aspectos sentimentales. De esta manera, la apertura de un discurso social individualista penetró fuertemente las estructuras enunciativas y atravesó la lógica de la cultura rock, en clave pop.

Se confirmó, entonces, una inmersión hedonista de intenciones apocalípticas y nihilistas en relación con el propio devenir político, económico y social del país. Del mismo modo, el desarrollo cultural del propio rock argentino también se vio afectado porque se encontraba atrapado en libertad, entre el éxito, la exportación y la proliferación de nuevas bandas orientadas a un rock urbano, esquivo y oscuro.

La perspectiva de libertad con temática nihilista provocó la fractura de un ideal superior y superlativo que, en el caso de las bandas pop-rock argentino, probablemente tenga su origen en el discurso punk (más que en su sonido). Esta huella nihilista propuso un código de identidad y una toma de conciencia de un futuro inapropiable o, al menos, confuso que debió ser considerado para no quedar atrapado por inocencias y aspectos inofensivos.

Por tanto, es posible destacar que la tematización de la libertad se vinculó con un espacio de desidia y de quehacer resignado, atravesado por la inmediatez del presente y las lógicas del aislamiento. La noción de libertad en este lapso constituyó una esencia de cultura rock de acuerdo a negaciones y carencias al vivenciar una situación de comercialización, espectáculo y moda. Se puede hablar entonces de una "temporalidad posmoderna" que ubicó al rock argentino en lucha, tensionado por las lógicas de vaciamiento en el universo cotidiano y los reconocimientos agotadores del contexto (Sanpedro, 2009: 71).

Por consiguiente, las líricas producidas en este escenario también manifestaban una concepción política obstruida que quizás anunciaba un culto individualista vinculado al neoliberalismo abrasivo de la década del 90:

Dejando de lado los intentos de definición de la posmodernidad como sinónimo de una época podemos asimilarlo al fin de la historia asociada con las doctrinas políticas y económicas neoliberales y una concepción global del mundo. La sociedad postindustrial, basada en las reglas de la tecnociencia, impactan sobre la sociedad de consumo, presentándose fragmentadas por la impersonalización, con el peligro de la autodestrucción del hombre, que genera incertidumbres, indiferencia y hasta un dejo de individualismo subjetivo narcisista, que hace sentir al hombre 
como un ser indestructible a la espera de la destrucción del mundo y de él mismo (Scatolini, 2011: 345).

Los discursos líricos manifestaban entonces, una tematización libertaria enlazadas con una construcción de abandono de pautas universales de gusto, justicia o verdad. Siguiendo a Larraín, se apreciaba una resignación ante la realidad incomprendida, vista como imposible de modificar (1998: 146). El discurso articulado en las líricas comenzó a exponer la ligereza de los postulados posmodernos y por ello declinaban de las exigencias de liberación y transformación social. Por consiguiente, la reivindicación del aspecto libertario fue trastocada por una mirada resignada que desvinculaba todo tipo de impulso contestatario, aunque se realizase desde un abordaje mínimo y sigiloso. De esta manera, la libertad, como concepto, idea o manifiesto, fue planteada en términos de desorientaciones y divisiones advertidas en la primera persona enunciada en los discursos.

\subsection{Análisis de las líricas}

Las líricas que integran este capítulo manifiestan un estado de crisis vinculado a la efectiva puesta en común de las libertades individuales y las correspondientes experiencias de vivir en un conjunto urbano y metropolitano. Las letras presentan identificaciones desde un plano social, condicionado por deseos y nociones pretendidamente escépticas. En función de ello, el análisis de las siguientes siete líricas articula una discursividad temática con interrogantes y miradas tensionantes sobre las prácticas de los jóvenes en un contexto democrático inestable o con una proyección sobre lo inseguro:

1) "Demoliendo hoteles" de Charly García es una canción que no fue editada en un período crítico de expectativas (se editó en 1984), no obstante articula un discurso de libertad de ruptura y un estado de fluctuación que reúne tanto las vivencias descontroladas del universo del rock como de la sociedad en su conjunto.

2) "Alguna vez voy a ser libre" de Fito Páez es una lírica que fue editada en una etapa sin resquebrajamientos en relación con la concepción democrática (se publicó en 1985), no obstante declama una reflexión que presenta definiciones existenciales y referencias tensionantes con la práctica de la cotidianeidad. 
3) "Planeta agua" de Los Encargados propone una situación apocalíptica en torno a una sensación de ocaso y una expectativa de libertad quebrantada, apreciada en virtud de una finalidad.

4) "Libre vivir" de Miguel Mateos manifiesta un entendimiento de la libertad desde un estado crítico que se debate entre el aspecto romántico de la vida y la desazón o el extrañamiento.

5) "Siento llegar" de Fabiana Cantilo incluye y sustenta un discurso de libertad proseguido por un contexto de diversión, pero también de insatisfacción y reflexión sobre un devenir de soledades y aislamientos.

6) "El rosario en el muro" de Don Cornelio y la Zona construye una narración crítica que pone en crisis las visiones eclesiásticas y cotidianas del universo familiar, colocando el foco en la liberación y la destrucción suicida del cuerpo.

7) "Edificios" de La Portuaria expone una situación de desgano y resignación frente al encierro, advirtiendo los peligros de vivir entre muros y reclusiones.

\subsubsection{Ahora no estoy más tranquilo}

"Demoliendo Hoteles"

Charly García (1984)

"Demoliendo Hoteles" es la canción que da inicio a uno de los discos más reconocidos y exitosos de Charly García: Piano Bar. Este material es el tercero de su etapa solista y es conocido también por la cantidad de clásicos que contiene: "Promesas sobre el bidet", "Tuve tu amor", "No se va a llamar mi amor", "Raros peinados nuevos", "Cerca de la revolución" y la mismísima "Demoliendo Hoteles".

Este álbum cierra la etapa más creativa y de formación de mito para García, luego de la realización de Yendo de la cama al living y Clics Modernos. Piano Bar, particularmente, es un disco con una incursión rockera directa, sin lujos tecnológicos desde lo sonoro y con una urgencia y desesperación avanzada desde lo lírico: “’Yo que crecí con Videla' es la frase de apertura y también un alarido generacional. García nunca había sonado tan punk como en 'Demoliendo hoteles', pero más allá de los niveles de intensidad, ironía y lirismo, todo Piano Bar esconde un romanticismo sombrío" (Rolling Stone, 2007: 16).

Es posible decir entonces, que Piano Bar marca definitivamente una tendencia importante en la discografía de García: la construcción de un yo-personaje que 
comienza a separarse del resto de la humanidad (Favoretto, 2013: 56). En función de esto, conviene señalar que tras el lanzamiento del disco, García se erigió seriamente como una estrella superlativa del rock local y profundizó así un estado turbulento de tomar la vida desde lo musical y lo lírico.

De hecho, parte del sufrimiento de su existencia como artista de rock se puede verificar en "Demoliendo hoteles", una canción que detalla una toma de conciencia y de posición en torno a las solicitudes de los seguidores de rock y las propias vivencias de los músicos en un estado de búsqueda libertaria: "Entonces periódicamente desafía al sistema pero esto no hace sino integrarlo más, como la rareza, la locura, el mal ejemplo del genio malogrado por el consumo de droga, etc..." (Blanco y Scaricaciottoli, 2010: 159).

Sumado a esto, "Demoliendo hoteles" también presenta una absoluta predominancia de la primera persona del singular, que representa la historia apuntándose como una referencia ineludible. El hablante construye así su enunciación a partir de la reiteración de su presencia en el relato, de tenor autobiográfico y de autorretrato, en franco vínculo con el devenir político y social del país.

"Yo que crecí con Videla, yo que nací sin poder.

Yo que luché por la libertad y nunca la pude tener.

Yo que viví entre fascistas, yo que morí en el altar.

Yo que crecí con los que estaban bien, pero a la noche

estaba todo mal".

Siguiendo esta interpretación autorreferencial, es posible advertir que el diagrama inicial de la lírica se marca a partir de la fuerte presencia de un yo lírico que conduce el discurso con un énfasis de supervivencia, destacando su lugar en el mundo y su predisposición a la resistencia, pero también al hartazgo.

La línea que comienza la enunciación podría indicar una idea de desarrollo y tránsito: yo que crecí con Videla. Por esta razón, el hablante se coloca como una figura heroica y estoica que resistió a los avatares complejos de una sociedad en tensión: yo que luché por la libertad. Se señala entonces un nacimiento desarrollado en dictadura, a instancias de las decisiones de un dictador (Videla) y de la desprotección (sin poder).

Del mismo modo, se sostiene una existencia y un despliegue relevante en un escenario autoritario (yo que viví entre fascistas), en función de un derrotero romántico (morí en 
el altar) y una práctica política de disfrute o goce combinado con peligro y desesperación: yo que crecí con los que estaban bien, pero a la noche estaba todo mal.

"Hoy paso el tiempo demoliendo hoteles.

Mientras los plomos juntan los cables, cazan rehenes.

Los chicos allá en la esquina pegan carteles".

En el estribillo, el hablante subraya una instancia deíctica y temporal que se enlaza con su actualidad de derrumbe y destrucción, desde un estereotipo cultural y de estirpe rockero: hoy paso el tiempo demoliendo hoteles. Desde su instancia de protagonista libertaria y rockera, el yo de la lírica presenta una discursividad casi despótica en la que deja evidencia su rol de dirigente en el universo de la cultura rock: mientras los plomos juntan los cables, los chicos allá en la esquina pegan carteles.

"Yo fui educado con odio y odiaba la humanidad.

Un dia me fui con los hippies y tuve un amor, y también mucho más. Ahora no estoy más tranquilo.

¿Y por qué tendría que estar? Todos crecimos sin entender y todavía me siento un anormal".

En la siguiente estrofa propuesta por la lírica, el hablante continúa su racconto y enlaza los acontecimientos de su vida con los cambios sociológicos del mundo. En principio, destaca una crianza de orientación negativa, perjudicial para una visión humanista: yo fui educado con odio y odiaba la humanidad. Luego, resalta su instancia introspectiva y de experiencia que permitió un cambio en su perspectiva de vida (un día me fui con los hippies y tuve un amor y también mucho más), pero finalmente vuelve a hacer hincapié en una situación actual de complejidad que lo inquieta (ahora no estoy más tranquilo). En virtud de ello, el interrogante admite una instancia de riesgo que intranquiliza al hablante y bloquea la libertad que no puede tener y que jamás pudo alcanzar, siguiendo su articulación enunciativa: ¿y por qué tendría que estar?

En consonancia, el hablante expone un interrogante sobre su intranquilidad (me siento un anormal) y aborda una expresión de primera persona del plural de desentendimiento y reflexión que trata de generalizar su pensamiento (crecimos sin entender). Teniendo en cuenta este último concepto, el enunciado final aprecia la distinción entre un yo 
presente en un contexto de discursividad y la norma correspondiente a una sociedad determinada. El yo, al construirse desde un lugar de obstinación y actividad rockera, se expone como un sujeto peculiar y determinante.

\subsubsection{Voy quedando solo cada vez más}

\section{"Alguna vez voy a ser libre"}

Fito Páez (1985)

El segundo disco de Fito Páez, editado en 1985 y titulado Giros, enfatizó desde una mirada de rock, aproximaciones al tango ("Giros"), la balada "Once y seis" y el folclore ("Yo vengo a ofrecer mi corazón”, “DLG”). De esta manera, el músico rosarino logró el lugar que lo ubicaba en la línea sucesoria de Charly García y Luís Alberto Spinetta: "Su fuerte personalidad, la calidad musical de sus canciones y la profundidad de sus letras no pasaron inadvertido ni para el público ni para sus pares” (Rolling Stone, 2007: 32).

De acuerdo con Sergio Pujol, la poética de Páez y su elaboración musical encontraban puntos de contacto con la hibridación cultural que lo destacan aún hoy del resto de los artistas del rock de la década del 80: "Ningún otro produjo un arte de tensiones y conciliaciones tan convincente y riguroso. Y tan argentino, si se me permite" (2010: 344).

En función de ello, el propio Páez se ha encargado de decir que comprende al universo musical del rock como una urgencia intuitiva, un choque que en muchas instancias precisa un mayor acceso de profundización y por eso necesita abrirse a otros panoramas como el tango o el folclore: "En el rock hay toda una cosa desenfrenada de gritos contra la sociedad, y delirios (...) El rock es un lugar donde se 'dicen algunas cosas', pero de última no pasa nada, qué se yo" (Guerrero, 1994: 92).

“Alguna vez voy a ser libre” es la tercera pista del disco Giros y, según el propio Páez, tiene un trabajo musical muy fino por su sonoridad y su representación en el disco. Particularmente, la lírica transita una problemática de vivencia personal que genera un marco enriquecedor, de intención existencial e indefinición. Por tanto, la canción atraviesa una suerte de resurrección motivada por la transformación y la libertad que permite elegir esa mutación: "No solo aparece la libertad ligada al tópico del viaje sino que la partida -o la fuga- constituye la concreción del ideal abstracto de la libertad" (Louge, 2008: 138). 
En la canción predomina la reflexión de una primera persona del singular que presenta definiciones de una situación de ansiedad e impaciencia. En función de sus descripciones, el discurso construye una existencia compleja y una relación tensionante con la práctica de la cotidianeidad. Desde la negativa se expresa un desarrollo en la sociedad y, asimismo, se señala una situación de probabilidad que, desde la modalidad, modaliza un deseo o un anhelo de libertad.

"No soy un pez, ni un arlequín, ni un extranjero.

No tengo edad para morir, amo este cielo.

No voy a esperar. Alguna vez voy a ser libre.

Libre, mi amor, como el amor, como quisiste".

El hablante parte de una negación, indicando que no es un personaje de agua, ni un bufón de comedia ni tampoco un sujeto ajeno a lo que sucede. Asimismo, se muestra impaciente, con un sentimiento de vida activa y con una voluntad de amar que podría concebirse cuando se alcance la libertad anhelada: alguna vez voy a ser libre.

"Voy silbando bajo y siento tu voz así:

una sirena de ambulancia. Voy quedando solo cada vez más,

¿y qué? Mi corazón ya no me basta”.

En esta situación, el hablante se muestra atento en un escenario que lo conmueve y lo comienza a interpelar (voy silbando bajo). Frente a esto, la aparición de la segunda persona del singular resulta fundamental, porque le sirve para enunciar una presencia aislada y en estado de alerta (siento tu voz así: una sirena de ambulancia). Así, se enuncia una construcción de dolor que lo ensombrece, lo resigna y también lo vuelve agresivo: voy quedando solo cada vez más ¿y qué? mi corazón ya no me basta.

“Veo el reloj veo las seis. Voy hasta el baño.

Ya amaneció y cerca de aquí, como en el barro.

Tengo que hacer, tengo que dar no que más pueda.

Ya anocheció y cerca de aquí, tengo las pruebas". 
En la tercera estrofa, el hablante realiza un relato en tránsito, en el que se despierta de un sueño y se encuentra en una situación confusa, entre la voluntad de hacer y dar y la caída o el ostracismo (veo el reloj veo las seis. Voy hasta el baño. Ya amaneció y cerca de aquí, como en el barro). Los deícticos espaciales le permiten señalar un contexto enloquecedor y derivar así una mirada apocalíptica (cerca de aquí como en el barro, cerca de aquí, tengo las pruebas).

\section{"Panorama para mí, para vos, por él. \\ Por los que fueron y vinieron. \\ Panorama enfermo en contradicción y yo, yo ya estoy listo como un perro.}

La cuarta estrofa atraviesa una noción de perspectiva panorámica que incluye tanto al locutor (para mí) como a la segunda (para vos) y tercera persona (por él) en un universo mórbido y caótico. El hablante se encuentra preparado para formar parte de alguna complejidad de vida $y$, del mismo modo, la elección de la tercera persona que incluye a él y a ellos que fueron y vinieron dan cuenta de una instancia más colectiva de la mirada apocalíptica. Este escenario destaca, a partir de ello, una situación de evasión y de desesperación por poder encontrar un lugar en el mundo y alcanzar la libertad obturada.

“Tengo un pasaporte en el bolsillo para irme de acá.

Tengo una canción en la cabeza y no puedo parar.

Tengo que salir, debe haber forma de resucitar.

Creo que estoy cerca mientras vos te alejes más y más”.

La deixis espacial destaca un empleo que se vincula con el área de disputa del hablante (acá), dando cuenta del propio contexto del país o también de la propia vivencia de juventud. Por tanto, el yo de la lírica cierra su enunciación subrayando que sus ansias de escape y deseo de ser libre o alcanzar la libertad no prosperan a partir de un contexto contradictorio y la consiguiente respuesta esquiva de su interlocutor.

Esta situación pendular permite advertir una vivencia del hablante que lo expone desde una circunstancia de encierro y laberinto que no le permite liberarse, pese a las distintas opciones que posee: tiene un pasaporte para escapar, tiene una canción para huir de lo 
tangible y tiene una posibilidad de acercarse a ese receptor que lo obsesiona. Por esto mismo, busca opciones para aferrarse a cierta esperanza y para evitar la angustia que lo atormenta y lo abruma: debe haber forma de resucitar.

"Porque yo no tengo mapa en este mundo.

Porque yo doy vueltas sobre el mismo punto".

Sin embargo, y a pesar de las intenciones de encontrar cierta paz o tranquilidad, el hablante destaca su situación apremiante. Desde la primera persona del singular se inscribe de un modo aseverativo en el enunciado y subraya una reflexión que condiciona: yo no tengo mapa en este mundo. La angustia termina apoderándose de la perspectiva del hablante porque profundiza su introspección abrumadora $\mathrm{y}$, asimismo, lo obliga a pensarse de un modo circular y hastiado: porque yo doy vueltas sobre el mismo punto.

\subsubsection{Al vacío}

"Planeta agua"

Los Encargados (1986)

Los Encargados fue una banda pionera del género tecno-pop en América Latina, formada en 1982, liderada por Daniel Melero e influenciada por agrupaciones inglesas como Depeche Mode, Yazoo y Human League, entre otros. Por su parte, Melero es uno de los músicos más importantes del rock argentino no tanto por su reconocimiento masivo, sino por su labor en la escena independiente y su distinción en el universo del underground, siempre pronunciado a favor del pop como enlace para el desarrollo del rock (Pujol, 2010: 334).

No obstante, y a pesar de la participación fallida en el Festival "BA Rock" en Agosto de 1982 (recibidos con piedras y proyectiles por el público rockero que esperaba a Riff y a Pappo), Los Encargados grabaron su primer disco recién en 1986. Dicho álbum, titulado Silencio, contiene dos de las canciones más emblemáticas de la banda: "Sangre en el volcán” y "Trátame suavemente", una lírica que se hizo conocida a nivel continental por la grabación de Soda Stereo en 1984.

En esencia, la historia de la grabación del disco sostiene una epopeya de resistencia y terquedad en lo que refiere a la vinculación de la banda con el universo discográfico: 
"En un medio hostil, Los encargados tuvieron que archivar dos discos antes de lanzar su álbum debut (...) Con Silencio el trío impuso un concepto avanzado de canciones electrónicas" (Rolling Stone, 2007: 26). Sobre este punto, Melero sostiene que la grabación de este disco sirvió, de algún modo, para revalorizar los trabajos subterráneos del rock argentino en tiempos dictatoriales: "Lo que nos une con el underground no es la música sino la marginalidad, la libertad de hacer cosas nuevas (Berti, 1986: 31) "Plantea Agua" es la décima pista de Silencio y es una de las canciones más enigmáticas de la banda e, inclusive, de la discografía de Melero en plan solista. La lírica presenta a un locutor que se encuentra en una situación apocalíptica: debe controlar el estupor de un interlocutor que vivencia una sensación de ocaso y una expectativa de libertad quebrantada, apreciada en virtud de una finalidad.

“Cómplice del miedo me mirás como idiota.

Puedo hablar en serio. Mañana estaré muerto.

Sé que tus labios me descargan al vacío.

El metal puede ser frío pero al menos es mi antojo.

Agua planeta”.

El campo semántico que ofrece la lírica oscila entre las conmociones de miedo y, asimismo, las impresiones de libertad individual. Por un lado, aparecen palabras claves como el miedo, la muerte, el vacío y el frío, pero también la seriedad, el mañana y el antojo como marco de decisión: mañana estaré muerto.

El hablante, por lo que se advierte a continuación, suplica un fin para su existencia y por eso intenta negociar su muerte con el interlocutor: el metal puede ser frío pero al menos es mi antojo. Este último es expuesto con cierto aprecio por el locutor porque, si bien aproxima una crítica (me mirás como idiota), también resalta una presencia romántica en la enunciación (tus labios me descargan al vacio).

Asimismo, vale mencionar la importancia del enunciado breve "Agua planeta", que aunque tenga una organización textual distinta, le da nombre a la canción y oficia de cierre de las dos estrofas que tiene la canción. Es la conclusión del comentario y la finalización de lo enunciado.

Ya no hay silencio. Se desborda el caudal.

El origen se dispersa en la compleja red eléctrica. 
Trato de agruparme y los destinos penden y se aflojan.

Es inevitable el abismo se aproxima.

Agua planeta.

Como se evidencia, el hablante ya no se remite a la segunda persona, sino resuelve su situación en soledad, observando cierto desmantelamiento ensordecedor, que como un alud destruye los alrededores. De un modo muy metafórico, el yo de la lírica articula un discurso negativo e inclusive atormentador, pero utiliza una estrategia muy sutil y críptica para destacarlo: hay desborde, dispersión, caudales y complejidad.

Por consiguiente, el locutor no señala una inquietud de escape ni una voluntad de huida, sólo intenta un resguardo (trato de agruparme), no obstante, existe una fuerza superior a él que no permite controlar el ocaso. Así, los destinos se tornan inevitables y activan el porvenir de muerte anunciado anteriormente (el abismo se aproxima).

En este sentido, el planeta no cobra una organización textual primordial, sino resulta secundario porque lo principal que se enuncia es el agua y luego, adicionalmente, el planeta. El agua, entonces, unifica ese desmantelamiento previo y hunde todo el porvenir. Ese abismo anunciado cierra toda identificación de libertad y es, predeterminadamente, un lugar inquebrantable.

\subsubsection{Sin ganas de seguir}

"Libre vivir"

Miguel Mateos (1986)

Miguel Mateos editó el último disco bajo el nombre de la banda Zas con la intención de cerrar una etapa artística prolífica y, de esta manera, abrir las puertas de su desempeño en solitario. Por esto mismo, en cuestión de meses, el artista publicó dos discos con un lanzamiento casi en simultáneo: Solos en América (con Zas), lanzado en 1986, y Atado a un sentimiento (disco debut solista), divulgado en 1987.

Solos en América es el nombre del sexto álbum de estudio de Zas y es considerado uno de los álbumes más simbólicos del rock argentino de la década del 80 , no sólo por el impacto nacional que generó, sino por el alcance masivo a escala latinoamericana. El álbum es conocido a escala continental por contener canciones emblemáticas del repertorio de Zas, como "Cuando seas grande", "Es tan fácil romper un corazón", "Sombra en la pared", "Llámame, si me necesitas" y "Solos en América". 
En este sentido, la figura de Mateos recobró una notoriedad mucho más auspiciosa en otros países que se profundizó por la simplicidad de sus composiciones y por la particularidad de forjar clásicos instantáneos que rotaban constantemente en las radios de Argentina, Chile, Perú y México, entre otros.

"Libre vivir" es la décima pista de Solos en América y oficia como cierre de etapa para la agrupación y para el mismísimo líder que meses después lanzaría su exitosa obra solista. En esta lírica predomina una primera persona del singular ocupada en un estado crítico, de relación tensionante, que se debate entre el aspecto romántico de su vida y su perspectiva política en cuestión de su mirada filosófica. En función de ello, la añoranza resulta un lugar común en la estrategia discursiva de la canción: el hablante se presenta activo para argumentar su período de desazón y extrañamiento.

Por esto mismo, el discurso se organiza a partir de la puesta en común de verbos que plantean una disposición ideal de la libertad, emparentada con el universo lúdico y la imaginación. Frente a esto, el hablante destaca el modo de diferenciar esa estrategia de libertad o de lo libre con un estado que roce el delirio e imposibilite la plenitud del acceso a la independencia:

"Soñar, jugar.

Es cuestión de diferenciar la libertad con el delirio.

Vibrar, cantar.

Todavía yo tengo fe en cosas que ya nadie cree".

En este sentido, el hablante ofrece verbos con una carga valorativa positiva que reúnen condiciones activas para construir un espacio de libertad, desde un entendimiento de fantasía y recreación (soñar, jugar). Así, la conmoción y los aspectos trovadores le sirven de estrategia para destacar que aún existe una posibilidad de conservar la esperanza en lo que otros olvidan o han dejado de lado (vibrar, cantar todavía yo tengo fe en cosas que ya nadie cree).

“Amar, volver a empezar y sentir esa sensación de estar jugando con fuego.

Tocar no estar. Una sombra en mi habitación escribe tu nombre sobre un vidrio" 
Siguiendo esta línea, el hablante postula una definición intencional sobre el amor y las ventajas de conquistar y enamorar, como un acto de reconfiguración personal que inquieta y trastoca las prácticas de la vida, contrayendo peligros y vaivenes: sentir esa sensación de estar jugando con fuego.

Sin embargo, en el último enunciado se articula un discurso de tensión que expone a un hablante en soledad, conviviendo con un sufrimiento y una ausencia que quizás lo atormenta (tocar, no estar). La libertad, en este caso, se muestra vinculada con el alejamiento y la reflexión ante el temor, el aislamiento y el quebranto amoroso: una sombra en mi habitación escribe tu nombre sobre un vidrio.

A partir de esta postura, el locutor se muestra desde un tono renegado y superior, apuntalando una situación de apocalipsis personal y, asimismo, destacando un momento de confianza en las últimas instancias. De esta manera, el yo de la lírica oscila entre un conocimiento de su actualidad, rozando el peligro de la experiencia netamente individual, contemplando la soledad y su angustia amorosa.

En función de este desengaño, el hablante expone un ideal de libertad vinculado con la individualidad y la defensa de las preocupaciones personales como propósito para alcanzar un estado de libertad y de vivencia. Por ello, se inscribe desde el discurso de un modo arraigado y concentrado, aseverando una perspectiva que cree favorable: "Quiero libre vivir. El problema está en compartir".

Por esto mismo, el discurso profundiza una mirada resignada ante la pérdida y la ausencia del interlocutor. El hablante se expone de un modo inestable, destacando una inevitable crisis que lo atormenta y lo subyuga. En este aspecto, el discurso se torna cada vez más reforzado en la afirmación desde una noción negativa sobre su propia realidad:

“Estoy perdiéndote y estoy seguro que

en pocas horas más no me podré sostener.

Sin ganas de seguir, te veré partir

y abriré tu carta que me dice:

'Quiero libre vivir','.

El cierre de la lírica señala una situación problemática para el hablante, puesto que el discurso confirma trágicamente un estado de soledad profundo y subraya la presencia de una libertad que amarga las expectativas esperanzadoras iniciales del locutor. En 
relación con esto, la lírica cambia de enfoque y se posiciona desde una perspectiva de despedida y de concepción individual que no resalta las virtudes del ser libre, sino, más bien, de un ser atormentado.

\subsubsection{Salgo a bailar con mi malestar}

"Siento llegar"

Fabiana Cantilo (1988)

Fabiana Cantilo es una de las cantantes más reconocidas y representativas del rock argentino. Si bien comenzó su carrera a principios de la década del 80 como miembro del grupo de rock teatral Bay Biscuits (que participaban como teloneras de Serú Girán o Patricio Rey y Sus Redonditos de Ricota), fue a partir de su participación en Los Twist y como corista de Charly García que ganó una aceptación masiva dentro de la cultura juvenil de rock.

El lanzamiento de la carrera solista de Fabiana Cantilo se llevó a cabo en 1985, tras la publicación de Detectives, producido por el mismísimo Charly García. Pese a las apuestas, el disco tuvo una rotación moderada y representó un avance muy significativo en la historia de la cantante, sobre todo a partir de la divulgación de dos canciones emblemáticas de su historia: "Detectives" y "Amo lo extraño".

El segundo álbum de Cantilo, titulado Fabiana Cantilo y los perros calientes, se editó en 1988 y fue producido por Fito Páez, su pareja de entonces. La obra simbolizó un acercamiento al pop desde una perspectiva rockera que no dejaba lugar a dudas desde su portada: “A esa tapa la hicieron sin preguntarme, me parece un opio, pero no importa, el disco es buenísimo y estuvo producido por Fito. Por entonces yo estaba muy rubia tipo Blondie" (Lescano, 2008).

Si bien la canción "Siento llegar" no es una de las canciones más conocidas del repertorio de Cantilo, se ubica como octava pista de un álbum que la confirmó como una solista de relevancia popular y como icono de época en un universo de rock dominado por la masculinidad.

Precisamente, en el discurso de la lírica predomina una primera persona del singular que, desde su rol femenino, construye un interlocutor oponente y delimita así un escenario de movimiento que empuja y conmueve su enunciación. En función de ello, el hablante se encuentra sostenido por un contexto de diversión que lo interpela y que, asimismo, le permite reflexionar sobre su devenir. 
"Yo no llamé, al impulsador.

Nunca soñé, con verte tan bien.

Te siento latir como un corazón.

Más brillo te da tu nuevo visón semimuerto"

El discurso de la lírica comienza con una inscripción directa del locutor y desde un rasgo de negación, que le permite desestimar lo que observa y abordar irónicamente el escenario que lo rodea. La segunda persona, en este caso, funciona como un antagonista y como el vehículo para dar rienda suelta a un discurso certero y conciso: yo no llamé, nunca soñé, te siento latir. La alusión al interlocutor entonces, sirve para exponer el lugar dependiente y frágil de ese otro que parece estar a merced de los comentarios del hablante: te siento latir como un corazón, más brillo te da tu nuevo visón semimuerto.

"Siento llegar un antiguo olor.

Tu capacidad desborda mi sed.

Me vas a engañar, a desvanecer.

Esclavizarás cada vez más mi memoria”.

En esta estrofa, el hablante anuncia la llegada de una sensación añeja, de otro tiempo que parece mal predisponer a la primera persona. En este sentido, la presencia del interlocutor sirve como destino para despotricar nociones de hastío y cansancio. El desborde de la sed podría plantear una instancia de hartazgo y una sensación abrumadora que refiere directamente a la segunda persona, quien parece instituirse de un modo capacitado y omnipresente.

El interlocutor, por consiguiente, es construido de un modo negativo y es articulado como un receptor fuertemente posesivo que genera desconfianza en el hablante. Dicha suspicacia genera prejuicios en el hablante y persuade de una manera nociva la relación: me vas a engañar, a desvanecer, esclavizarás cada vez más mi memoria. No obstante ello, este planteo oscilante propuesto por el hablante habilita interpretaciones diversas porque, si bien existe una preservación de la individualidad y la autonomía, el yo de la lírica genera un dominio peculiar en su interlocutor, provocándolo desde la ironía y la negación constante. Por ello, a partir de esas enunciaciones que destacan nociones 
actitudinales, el hablante expone cierta inseguridad de existencia que es profundizada en el estribillo: "Quiero usar tu libertad, desmoronar mi soledad".

Frente a esto, la soledad es el denominador común que quizás tienen el sujeto hablante e interlocutor en la relación. Tal vez aún más desde la perspectiva del hablante que procura tomar la libertad de su acompañante con el objeto de mantenerlo en una ligazón continua que contribuya a derribar todo tipo de aislamiento. En esta compleja red, la primera persona procura resguardar su individualidad y su hedonismo utilizando como botín la autonomía del interlocutor.

"Sin gravedad y sin voluntad. Salgo a bailar con mi malestar de siempre. Ya me cansé de no tener a quien matar y regalar unas flores".

En este caso, la diversión desde el baile se construye como espacio de libertad que, particularmente, la primera persona no disfruta en su plenitud y le permite, al mismo tiempo, admitir el regocijo del interlocutor, quien disfruta el escenario sonoro y corporal. Por tanto, el locutor considera al baile como un lugar para alcanzar objetivos perdurables y, de la misma manera, como un lugar secundario que acompaña un fastidio propio, que no satisface en absoluto su experiencia.

El hablante oscila entre la perspectiva apocalíptica y la desidia, postulando un interlocutor oponente, que disfruta del contexto que lo acompaña y también sostiene los propios deseos de su compañía insistente. Siguiendo esta línea, el hablante ejerce una función fascinante sobre el interlocutor, exponiendo así un convencimiento de acciones y una posibilidad de identidades diluidas.

\subsubsection{Destruir tu cuerpo es liberación}

“El Rosario en el Muro” Don Cornelio y la Zona (1987)

La canción "El rosario en el Muro" es, junto con "Ella Vendrá y "Tazas de Té Chino" una de las canciones más conocidas de la banda Don Cornelio y la zona. El tema está ubicado como tercera pista en el disco debut de la banda, editado en 1987 y producido por Andrés Calamaro. El álbum representó un éxito instantáneo para la banda porque generó rotación radial instantánea y porque tenía una idea conceptual muy interesante a 
partir de un discurso lírico que exponía debates metafóricos y tramas representativas de la posdictadura.

Dicha obra generó un espectro lírico de orientación bailable, que proponía alejarse de los residuos provocados por la última dictadura cívico militar y abrazar la atmósfera creada por la democracia. En términos de Palo Pandolfo, líder de la banda, el álbum servía para exorcizar los demonios de la dictadura y distanciarse de la retórica militante: "Éramos la cría del Proceso, habíamos visto tanto cine europeo, tantos poetas malditos, tanta bandera y bombo (...) que de pronto salimos a la pista con una especie de fiebre bailable con contenido intelectual" (Aguirre, 2012).

Por tanto, "El rosario en el muro" propone un juego de fantasía con el propósito de poner en crisis la idea del suicidio y la situación social en tiempos de democracia: "Igual yo no pensaba en ese momento que la revolución era un suicidio, sino que esa era la metáfora. Como una cosa violenta contra la propia madre (...) La palabra clave es liberación. Y es como relacionar lo sexual y lo político" (Jalil, 2016).

En dicha lírica predomina una narración omnisciente, en el que se relata una historia crítica sobre dominación, muerte y religión. Se advierte así una narración crítica sobre las vicisitudes de la cotidianeidad, incluida desde raigambres eclesiásticas y sexuales: el locutor construye un discurso en el que existe una tercera persona que expresa un dolor en la existencia y que se encuentra sofocado por su propia realidad apocalíptica.

\section{“Aquella mañana él se despertó, casi sin aliento, con mucha tos. El rosario en el muro. \\ Hijo mío sos esclavo de Dios... Maldito pecador".}

La estrofa inicial diagrama un paisaje continuo e importante en la lírica, una zona de crisis que resalta un objeto delicado que reitera constantemente el tormento del protagonista: "El rosario en el muro". Este último enunciado refiere, quizás, a un joven destacado como nexo directo que se desplaza en un escenario de tragedia y desventura. De acuerdo con la narración, el protagonista se encuentra agotado, sin posibilidades de descanso ni sueño profundo, atormentado por la existencia de su cuerpo y una realidad que parece esclavizarlo.

Sobre este último punto, conviene resaltar la existencia de un punto de vista enunciativo que comparte el diálogo con el narrador omnisciente que, en primer lugar desencadena su relato desde la tercera persona (aquella mañana él se despertó), no obstante, en 
segunda instancia le da lugar a otra voz que interpela directamente al protagonista de la historia y podría tomar el papel de su madre: hijo, mío, sos esclavo de Dios, maldito pecador. En este sentido, el enunciado incluye una tensión que genera confusión porque es un sujeto que tiene presente a Dios, pero a la vez es más pecador que santo (Rozitchner 2003: 57).

\author{
“Mamá respiraba, tenía pulso. \\ Casi sin aliento, los senos sueltos. \\ El rosario en el muro. Madre, quiero tu sexo"
}

En la siguiente estrofa, el hablante omnisciente que antes narraba en tercera persona y le había dado el lugar a una segunda voz para que interpele al protagonista parece también narrar desde la primera persona. En este caso, se destaca la descripción de una madre a punto de fallecer, que aún con pulso y respiración, se encontraba al borde del hálito: "mamá respiraba, tenía pulso. Casi sin aliento, los senos sueltos". En consecuencia, más allá de las voces que lo enuncia (desde la tercera a la primera persona), la historia presenta una tensión entre el protagonista y su vida: existe un hijo atrapado por la asfixia que, asimismo, sufre y tal vez siente responsabilidad por la enfermedad de su madre.

El enunciado el rosario en el muro se expone como un mantra omnipresente, que acompaña el devenir del acontecimiento que se narra e impone una situación atravesada por la religión: la presencia de Dios enfatizada por el rosario, la esclavitud y el pecado. En función de ello, la narración modifica el foco del relato y se centra en la primera persona: madre, quiero tu sexo.

Este enunciado también genera diferentes interrogantes porque, desde un primer término, destaca un lazo fuerte entre el tormento del hijo y la defunción de la madre: ¿el protagonista desea el sexo de la madre en pos de una situación erótica o maternal? ¿Ese sexo reclamado implica que el protagonista necesita cobijarse en lo más íntimo de la madre para escaparse de ciertos tormentos? De acuerdo a esto último, es posible pensar que la primera persona quiere ese sexo para volver al lugar de nacimiento, como una manera de apartarse de su vida de pecador, el sufrimiento de su madre y su situación actual (Rozitchner, 2003: 59).

“Corre y sube la escalera ya, y ajusta tu corbata. 
Aunque llores, reces y te humilles, nene,

la salida de tu vida es la caída.

Si ya estás en la azotea salta. Si ya estás en la azotea

salta. Si ya estás en la azotea”.

En esta estrofa, el locutor le habla directamente al personaje de la historia. Lo incentiva a un final abrupto, es decir, al suicidio, a pesar de cualquier deseo que intente aliviar su existencia: aunque llores, reces y te humilles, nene, la salida de tu vida es la caída. Lo invita a arrojarse al vacío desde una plataforma y lo estimula a saltar por sus pecados con una insistencia cínica, apelando a un sentido común impasible: si ya estás en la azotea salta.

En este sentido, el locutor también describe al personaje como un sujeto modesto, que lleva corbata y que, a pesar de su acto suicida, no debe perder la compostura ni el estilo: ajusta tu corbata. Del mismo modo, el locutor estimula el salto al vacío para subrayar el remordimiento de un personaje desconsolado y dominado por un sentimiento de culpa. El pecado, en este caso, oficia como eslabón primordial para la angustia del personaje: ya no puede ser libre si siente que su conciencia es impúdica e insultante para los valores impuestos por Dios (sintetizado en ese rosario en el muro) y su madre (agonizante).

\section{“Aquella mañana la calle tembló. Destruir tu cuerpo es liberación.}

El rosario en el muro. ¿Quién me habla?

No entiendo, no, señor. El rosario en el muro, no, no, no".

En esta estrofa, el narrador omnisciente regresa con su relato contextual en el que destaca una situación turbulenta para el protagonista: la destrucción de su propio cuerpo y la enunciación de la libertad a partir de esa decisión. El enunciado latiguillo el rosario en el muro escolta esta opción suicida para el protagonista que, en la misma estrofa, resalta desde la primera persona, una connotación de paranoia y desconcierto: ¿quién me habla? No entiendo.

De esta manera, el interrogante refuerza la sensación de desmán que conmueve al protagonista $\mathrm{y}$, del mismo modo, es la puerta de entrada para que se le reclame entendimiento a una fuerza superior: no entiendo, no, señor. En este aspecto, el enunciado reiterado el rosario en el muro se remarca desde el tormento, y es un objeto 
fatal que contribuye a la paranoia e incrementa la culpabilidad que siente el protagonista. Este último proyecta su culpa sobre la cruz y la pared.

La liberación, por tanto, se aprecia desde la destrucción y la implosión del propio cuerpo, entendido como un disfraz que permite los pecados y da lugar a las culpas. El protagonista, por esta razón, entiende que su cuerpo es la culpa de los males, que sus deseos aparentemente lo atan a una situación impura e insultante para Dios (proyectado en ese rosario). La libertad entonces, se encuentra paradójicamente en la muerte y la destrucción del cuerpo.

“Un escalón y tus rodillas rojas.

Dos escalones y tu grito en las astillas.

Tres escalones y tus recuerdos.

Cuatro escalones y el viento $y .$.

Si ya estás en la azotea salta. Después de esta vida

loca, ¿Para qué seguir así, nene?”

En la siguiente estrofa, el locutor retrocede el relato y ubica el foco en la instancia previa a la caída del personaje principal. Por esto mismo, se relata el ascenso del protagonista por una escalera de madera: lo hace de rodillas (rojas, marcadas, quizás, sangrientas), doliente (tu grito en las astillas), atormentado por la culpa (tus recuerdos) y con el suspenso de una corriente que lo acompaña cuando encuentra la previa al vacío (cuatro escalone y el viento y...).

Es posible señalar que esos recuerdos que acompañan el camino a la azotea, significan una explicación que integra lo que el personaje siente por la situación que atraviesa la madre: "La madre enfermó, él cree que la enfermedad la causó él mismo, por ser muy pecador, y ahora se tiene que matar para hacer justicia" (Rozitchner, 2003: 60). En función de ello, el locutor espeta una pregunta inquisidora que se sustenta en un argumento y que expone las razones de esa culpabilidad atormentadora para el personaje principal: después de esta vida loca ¿Para qué seguir así nene? 


\subsubsection{Mejor salir}

"Edificios"

La Portuaria (1989)

La Portuaria es una banda de rock argentino fundada hacia finales de la década del $80 \mathrm{y}$ liderada por Diego Frenkel, ex integrante de Clap, una de los grupos más reconocidos de la escena undergorund del período. El disco debut de La Portuaria se publicó en 1989 y se tituló Rosas Rojas, contando con la participación de músicos reconocidos de la escena alternativa: Christian Basso, Sebastián Schachtel y Axel Kriger, entre otros.

Si bien el álbum no tuvo una rotación significativa, vale decir que obtuvo una aceptación positiva por parte de la crítica, sobre todo a partir de la vinculación entre sonoridades nuevas (profundizadas entre las orientaciones musicales del pop, el folclore y el rock). Por esto mismo, Frenkel se ha encargado de declarar, en diferentes oportunidades, que dicho material simbolizó un acercamiento a los múltiples formatos que evidenciaban como banda: "La diversidad y el eclecticismo siempre fueron parte de la esencia de La Portuaria. No sé bien porqué; supongo que tiene que ver con la inquietud, con una búsqueda, con una forma de ser (...) Tiene que ver con una raíz de La Portuaria, desde Rosas rojas" (Casciero, 2003).

La canción "Edificios" es la tercera pista Rosas rojas. Particularmente, la lírica se construye a partir de un relato que refiere a una segunda persona, que figura como un destinatario directo y propicio para la advertencia. En este sentido, la inscripción del yo se invisibiliza y se coloca el foco en una constancia de segunda persona que demuestra desgano y resignación frente al encierro.

\footnotetext{
"Estás sentado frente a la TV, te sientes solo y sin nada que hacer. Leyendo el diario, oyendo una canción. Matando el tiempo, soñando una ilusión”.
}

Como se expone, la estrategia del enunciado se construye en función del empleo del gerundio que destaca una situación de movimiento estancado (leyendo, oyendo, soñando). El locutor desarrolla así un discurso en el que se despliegan tres diagnósticos sobre la segunda persona: primeramente, se advierte una instancia pasiva y de quietud o aburrimiento (sentado frente a la TV, te sientes solo y sin nada que hacer), luego se 
aprecia una circunstancia que denota un exceso de pasatiempo (leyendo el diario, oyendo una canción) y una última cuestión que destaca una ansiedad idílica e hiperbólica: soñar una ilusión.

“Te estás diciendo que todo acabará, que ya no hay vida, que ya no hay verdad.

Te estas hundiendo sobre tu sofá y estás pensando que todo acabará"

Por esto mismo, la siguiente estrofa refiere al discurso que opera sobre la segunda persona, que en este aspecto se encuentra en un estado de resignación y de suspensión emocional. En función de ello, el hablante recupera comentarios apocalípticos de un interlocutor que le sirve a los efectos de delimitar un horizonte mucho más amplio de receptores: te estás diciendo que todo acabará, que ya no hay vida, que ya no hay verdad. De esta manera, el discurso negativo del interlocutor se agrupa para ofrecer una nueva perspectiva en el estribillo, que permita alcanzar un modo de escapar de la quietud (tu sofá) y el ensimismamiento perjudicial (estás pensando que todo acabará).

"Mejor salir de los edificios.

Mejor bailar que andar entre pasillos".

El estribillo da cuenta de una posibilidad que podría mejorar la situación del interlocutor $\mathrm{y}$, del mismo modo, del propio hablante. En este sentido, la postulación se realiza de un modo general, con una intención universalista y de recomendación que asevera una acción en detrimento de otra. La palabra mejor está utilizada en dos sentidos porque permite comprender una conformidad o una conveniencia en términos calificativos, pero también denota una instancia adverbial de preferencia: mejor salir, mejor bailar.

Del mismo modo, la salida y el baile se contraponen al encierro propuesto por los edificios y sus recorridos internos. Se construye así una idea de salida, a partir del baile y en contraposición de la acción de transitar entre muros, paredes y paneles. Como se mencionó, el locutor ya no se dirige de manera unívoca a una segunda persona específica, sino postula destinatarios generales, y frente a esto la actitud que se revaloriza se relaciona con una perspectiva activa y verbal: salir y bailar. 


\subsection{Consideraciones parciales}

\section{Entre la libertad y el desencanto: claves y pistas de una nueva enunciación}

Las líricas analizadas en este capítulo remarcan un discurso con articulaciones fragmentarias que postulan relatos de incertidumbre o de aspectos nihilistas. En este sentido, y como se advirtió anteriormente, las letras profundizan una estrategia enunciativa individualista que confirma una exploración hedonista y sensualista.

A partir de ello, es posible apreciar una lógica discursiva de intenciones apocalípticas y escépticas vinculadas con el propio contexto político, económico y social de crisis democrática. Por esto mismo, la perspectiva de libertad con temática nihilista provoca una marca de identidad que es revisada en virtud de las miradas desconfiadas y poco proyectuales.

La tematización de la libertad que postulan las líricas activa un espacio de desidia y de tarea resignada, atravesada por la existencia de un presente perpetuo que encuentra su lógica en el aislamiento. La noción de libertad se constituye así en relación con una esencia de negaciones y carencias que dan cuenta de un marco de situación de comercialización, espectáculo y moda, desde la óptica de la cultura rock, y un cierre de expectativas políticas en función del devenir democrático.

Las letras seleccionadas para este capítulo se encuentran condicionadas por deseos y nociones pretendidamente recelosas que podrían anunciar el ingreso del neoliberalismo en el plano social, político, cultural y económico del país. Por su parte, la tematización libertaria advierte un abandono de pautas universales de verdades absolutas y articula también una comprensión que podría sintonizar postulados posmodernos de resignación, desestimando las construcciones que entienden a estas líricas desde una configuración liviana y vacía, sino más bien de diagnóstico y definición.

El discurso de la lírica manifiesta entonces un estado de crisis relacionado con la proliferación defensiva de las libertades individuales como experiencia para vivir en un conjunto urbano y metropolitano. Al respecto, las letras presentan condicionamientos en relación con las lógicas de los deseos y activan pretensiones escépticas sobre la libertad y la convivencia democrática.

En función de ello, existen interrogantes y miradas tensionantes sobre las prácticas de los jóvenes que refuerza inestabilidades y proyecciones de inseguridad. Por un lado, se articulan discursos que profundizan la primera persona y abordan temáticas de 
desmantelamiento y ruptura ("Demoliendo hoteles", "El rosario en el muro"). También se resaltan instancias de angustia existencial que se anuda directamente con la vivencia cotidiana y de convivencia democrática (“Alguna vez voy a ser libre”). Continuando esta idea, la postulación de escenas apocalípticas y/o negativas prolifera a partir de campos semánticos que subrayan quebrantamientos ("Libre vivir”), ocasos personales ("Planeta Agua", "Edificios") e insatisfacciones que profundizan los peligros de la convivencia en soledad o en compañía, sin distinciones ("Siento llegar"). 


\section{Capítulo $\mathrm{X}$}

\section{Consideraciones finales}

"Cuando arrojes al mar

las cenizas de la pasión, no hablaré del final por ninguna razón" "En el borde”, Soda Stereo (1988)

Las presentes líneas finales sirven para remarcar la importancia del estudio discursivo en la comprensión de la relación entre las letras de rock-pop argentino, la temática de la libertad y el escenario complejo de transición democrática. Particularmente, este capítulo no propone concluir el trabajo ni considerar un cierre de perspectiva, sino pretende recuperar las parcialidades expuestas en cada instancia del trabajo para ser pensadas a futuro. Por ello, en esta etapa de la tesis se busca una idea de despliegue y de plataforma para encontrar nuevas maneras de alcanzar interpretaciones y nociones.

Las actuales consideraciones comprenden que la tesis se diagramó desde una perspectiva contextual, subrayando la relación entre las líricas de rock-pop argentino y los diferentes discursos que circularon en un período de transición democrática.

Ante esto, la obra destaca la importancia de la cultura rock como manifiesto generacional y como herramienta para promover diagnósticos y decisiones en torno a vivencias y experiencias. Por esta razón, el análisis de las letras de rock-pop argentino se efectuó a la luz del escenario político, social y económico que transcurrió entre los años 1982 y 1989, teniendo en cuenta las problemáticas de la región y los significantes globales de las finalizaciones de gobiernos autoritarios.

Continuando esta idea, cada capítulo de análisis propuso una mirada discursiva coordinada y relevante en relación con las canciones de rock-pop argentino y sus contenidos, la consideración del contexto y la constante asimilación de las propias coordenadas de la cultura rock.

Los discursos esgrimidos en las letras diagraman un escenario de expectativas presentadas a partir de enunciaciones simbólicas y/o explicitas sobre la libertad. Siguiendo esta línea, las líricas proponen búsquedas en pos de diferenciarse de la solemnidad y acercarse a la diversidad y la libertad. Por un lado, se ubica al baile y la 
corporalidad como lugar de transformación y, por otro, se construye un discurso de centralidad irónica y/o lúdica que postula demandas en los términos cotidianos.

En este sentido, las letras también construyen una discursividad de tensión con ciertas prácticas de los ciudadanos y de los jóvenes en particular en un marco democrático. Por consiguiente, el eje del individualismo profundiza un aspecto distintivo que se relaciona con los alcances del placer, la escapatoria y la abulia en un ámbito de vida urbana. Este repertorio discursivo, también remarca articulaciones fragmentarias y relatos de incertidumbre que profundiza una estrategia enunciativa hedonista y sensualista.

Las construcciones discursivas propuestas en las líricas admiten, desde una revisión actual y contemporánea, otras versiones de los hechos y habilitan nuevas opiniones sobre la temática de la libertad. Frente a las referencias diversas que declaman una posibilidad de contenido vacío o meramente celebratorio, el trabajo aporta un matiz y una advertencia: las letras no fueron un mero destaque en torno a lo musical, a la festividad, el optimismo o el individualismo con el que se esperó el advenimiento democrático. Las letras también construyeron otros modos de consagrar la reflexión en relación con la libertad, la democracia y las prácticas juveniles, más allá del logro comercial o de las instancias genéricas del pop y la masividad.

Siguiendo este camino de exposición, el análisis de las letras construidas como corpus manifestó el surgimiento, la circulación y la consolidación de elementos significativos del imaginario colectivo durante la transición democrática. Por esta razón, fue posible advertir representaciones de vida o de existencia e, igualmente, una apuesta discursiva en torno a relaciones sociales, inquietudes y sensaciones de creer, sentir y vivir en un escenario democrático, luego de la oscuridad dictatorial.

El análisis admitió un acercamiento interpretativo de enorme riqueza que precisó una situación de nuevo tiempo y de desafíos, logros y complicaciones en la consagración de una temática libertaria en democracia. La perspectiva analítica se construyó como un una aproximación descriptiva, que entre rasgos y huellas, fue construyendo un corolario de intencionalidades y subjetividades.

En tanto, si bien se presentó un corpus de canciones con una orientación musical similar, también se trató de líricas diversas y heterogéneas que presentaron discrepancias y pretensiones diferentes si se tienen en cuenta los modos de consagrar una libertad. Por consiguiente, la incitación al baile, a la alegría y a la aparente frivolidad no representó un obstáculo para que el ideario rockero de protesta y reclamo permanezca bajo otras formas, otros lenguajes y otros signos. Algunos enunciados se 
encontraron más expuestos y visibles, y otros se expresaron a partir de figuras $\mathrm{y}$ simbolismos que re-significaron la libertad en función del pasado dictatorial, la actualidad democrática tras la asunción del presidente alfonsín en 1983, la celebración del cuerpo y la ironía, la noción individual y la perspectiva nihilista, respectivamente.

Como se ha visto, el planteo analítico y/o teórico de la tesis doctoral plantea un modo de abordar la producción lírica del rock argentino que es distintivo y referente con la teoría de la enunciación. Por esto mismo, en la investigación se optó por el análisis discursivo porque permite desentrañar determinados sentidos que no aparecen de manera explícita en los discursos que se analizan y que van más allá de lo temático, y los tópicos frecuentes.

Por esta razón, las inquietudes que aparecieron en el inicio de la investigación se orientaron hacia el desarrollo del contexto, la vinculación de la cultura rock como una condición de producción relevante para analizar los discursos de las líricas. La formulación de ciertas preguntas habilitaron la exploración del corpus seleccionado, y permitieron articular las categorías de análisis (la deixis, la modalización y la polifonía) en relación con una perspectiva discursiva-enunciativa: ¿Quiénes participaban de la situación comunicativa en las líricas? ¿Cuáles eran las características del contexto? ¿Cómo se inscribían las personas del discurso en la estrategia enunciativa? ¿Qué hablante se inscribía en las líricas del rock-pop argentino constituidas para el corpus? ¿Qué estrategia discursiva resultaba predominante en la tematización de la libertad? ¿Qué posibles efectos de sentido produjo dicha construcción?

A lo largo del trabajo, estos interrogantes o estas especulaciones fueron encontrando resoluciones que continúan contribuyendo al debate y profundizando también reflexiones posteriores. De este modo, se entiende que el discurso propuesto en las líricas de rock argentino subrayó un carácter no sólo prescriptivo normativo, sino también productor de condiciones de cambio de las prácticas comunicacionales de la sociedad de época.

La revisión del vínculo entre el campo disciplinario de la comunicación en tanto prácticas y saberes permitió observar la capacidad de intervención de las instituciones durante la pos-dictadura y en un marco de reconfiguración entre el Estado y la sociedad civil.

Así, el trabajo expuso una discusión sobre la cultura rock argentina de un modo tensionante porque destaca sus niveles caóticos, contradictorios y confusos con la industria cultural. Tomando como referencia los discursos sociales expuestos en las 
instancias líricas de cada banda/artista/músico, la gran transformación del rock argentino se encontró a partir de la relación con un público extendido y masivo que forjó un diálogo cotidiano e inevitable en el planteamiento de sus enunciados.

De acuerdo con lo último, la convivencia entre los diferentes discursos se certificó y se autentificó en un mismo campo de manifestación y difusión. De esta manera, la tensión generada por la perspectiva pop en el desarrollo del rock argentino posterior a la derrota de Malvinas consolidó una conciencia democrática basada en la libertad y la valorización de la identidad del joven en un contexto de transición y complejidad.

La clave de las bandas/artistas/músicos de orientación pop prendieron aspectos en los jóvenes (sobre todo provenientes del teatro, el cine y la música rock, naturalmente) y promovieron discursos que fueron adoptados a partir de códigos de ironía, burla y parodia para precisar el estado momentáneo y dinámico de la sociedad argentina (desde un plano urbano, claro está). Se optó entonces por volcar el lenguaje textual del rock hacia el divertimento, el subterfugio, el riesgo estilístico y los aspectos bailables de un modo primordial y hegemónico.

Por ello, a partir de lo destacado y subrayado, este capítulo expone una línea de balance y consideración que procura recuperar el carácter lingüístico y rockero del período 1982-1989. En tanto, la reflexión sobre el rol de la cultura rock durante el período temporal constituido no significó solamente pensar los discursos sociales del momento, sino promover también una abstracción crítica en torno al alcance de un fenómeno generacional y colectivo que, desde sus discursos, convivió (y en algunos casos padeció contradictoriamente) y se relacionó de un modo inédito con la cultura oficial y sus mecanismos de articulación.

Al respecto, es posible hallar nociones de tensión y negociación en las distintas tematizaciones de la libertad porque, entre la mirada del divertimento y de lo apocalíptico, se diagramó una instancia plural que registró un modo de vivir y concebir la existencia.

En este aspecto, el principal valor de estas líricas consistió en hacer valer y en priorizar los impulsos estéticos y diferenciales (antagónicos) postulados por el discurso del rock argentino. Las tematizaciones de libertad propuestas por las líricas seleccionadas permiten verificar y advertir en la actualidad profundas tramas y sentidos contextuales de la sociedad. Por tanto, el estudio de las canciones y sus discursos enriquecen el análisis lingüístico y además permiten dar cuenta de múltiples sentidos que circularon en la época. 
En consecuencia, el análisis discursivo de las letras puso también en evidencia otro debate político y académico necesario: la reflexión sobre la democracia y, en este caso particular, la transición democrática como rasgo primordial para rechazar mandatos perpetrados por la dictadura cívico militar, pero también para subrayar residuos que aún hoy se encuentran impregnados en la sociedad. Por esto mismo, en las líneas previas, no se abordaron concepciones de la democracia desde lugares vírgenes, sino en función de las diatribas pre-existentes, mediadas por la violencia política y, fundamentalmente, por las consecuencias del genocidio y el terrorismo de estado.

Este puntapié principal permite comprender la importancia de repensar los acontecimientos de la Argentina contemporánea y, de la misma forma, reflexionar sobre la importancia de postular una política de Estado que se vincule con la revisión del pasado reciente. Por tanto, la consideración conceptual sobre la democracia y las consiguientes instancias de pensamiento revitalizan su definición y resultan relevantes en un contexto como el actual, que advierte construcciones hostiles, excluyentes y oclusivas en relación con los últimos cuarenta años del Siglo XX.

La actualidad de la Argentina, a un año del inicio del mandato constitucional del presidente Mauricio Macri, da cuenta de un cierre de etapa en cuestiones de Memoria, Verdad y Justicia. En este sentido, las ópticas neo-conservadoras y neo-liberales del nuevo gobierno traen consigo mandatos que articulan lo más residual y funesto del período de transición democrática: actualización de la teoría de los dos demonios, resignificaciones "pacificantes" o forzosamente conciliatorias en torno al pasado dictatorial, calificaciones que desestiman las vinculaciones políticas y/o partidarias de las juventudes, des-financiamiento de proyectos artísticos y estéticos que incluyen a los mismos jóvenes y atomización de recintos culturales que pueden integrar tanto a manifiestos desde el rock como de otros géneros de identificación contracultural.

En este escenario, el propósito del trabajo acompaña una revalorización de la libertad como temática y tópico direccionador y orientador de nuevas perspectivas y renovadas concepciones. Resulta imposible entonces, dar por finalizada una interpretación o una mirada respectiva sobre las instancias modales que diagnostican un ideal de libertad o una manifestación libertaria. Por esto mismo, la improbabilidad de cierre se destaca por dos cuestiones esenciales: en primer lugar, el estudio del discurso no tiene un articulación concluyente, sino todo lo contrario, es más bien dialógica y discutible; en segundo término, existe una contradicción en la tentativa de finalizar un trabajo que 
recupera nociones tanto de la historia reciente como de los manifiestos de una determinada cultura juvenil y también transgeneracional.

Siguiendo esta línea, la investigación se efectuó teniendo en cuenta las cenizas de una pasión, es decir, las influencias, las herencias y los legados de un rock argentino en estado de gracia y en ascenso invaluable. No obstante, la mirada de ese pasado no se hizo ni se hace -en este capítulo- de un modo idílico y/o con críticas feroces hacia un presente más bien confuso del rock argentino actual (ya no se habla de exportación, ni de dominio contracultural, ni de una comercialización flagrante).

La observación, el estudio y el análisis de la historia reciente del rock local y. por consiguiente, del país consideran en esta tesis una perspectiva a futuro que desestima los cierres de los relatos y descarta las finalidades. En función de ello, la actualidad del rock argentino merece ser pensada como una continuidad y como una posibilidad para seguir debatiendo los aportes de los contextos históricos. Vale entonces, repensar la situación de comunicación a partir de la propia historia de la cultura rock argentina y, también, en virtud de las persistencias que puede generar este trabajo doctoral: si mañana es mejor y siempre es hoy, el pasado es real y el futuro, libertad. Y no será un final, bajo ninguna razón. 


\section{Bibliografía}

\section{Libros y artículos}

- Aboy Carlés, G. (2013). "Raúl Alfonsín y la fundación de la 'segunda república'. En Gargarella, R., Murillo, M. V., y Pecheny, M. (coord.). Discutir Alfonsín. Buenos Aires: Editorial Siglo XXI.

- $\quad$ Alabarces, P. (1993). Entre Gatos y Violadores. El rock nacional en la cultura argentina. Buenos Aires: Colihue.

- $\quad$ Alabarces, P. (2008). "Posludio: Música popular, identidad, resistencia y tanto ruido (para tan poca furia)". En Revista Transcultural de Música Transcultural Music Review [en línea]. Consultado el 10 de octubre de 2016 en < http://www.redalyc.org/articulo.oa?id=82201207>.

Albaladejo, T. (2009). "Retórica de la comunicación y retórica en sociedad”. En Revista Crisis de la historia [en línea]. Consultado el 10 de octubre de 2016 en < http://www3.ubu.es/blogubuabierta/wp-content/uploads/2014/07/T.Albaladejo.-

Ret\%C3\%B3rica-de-la-comunicaci\%C3\%B3n-y-ret\%C3\%B3rica-en-sociedad-2.pdf>.

Angeli, S. (2005). "El gobierno de Raúl Alfonsín (1983-1989)”. En Dobaño, Palmira y Lewowicz, Mariana (Comp.). Cuatro Décadas de Historia Argentina. Buenos Aires: Universidad de Buenos Aires.

- $\quad$ Angenot, M. (2010 El discurso social. Los límites de lo pensable y lo decible. Buenos Aires: Siglo XXI editores.

Arregui, J. \& Choza, J. (1991). Filosofia del hombre: una antropología de la intimidad (Vol. 4). México: Ediciones Rialp.

Aulicino, J. (2008) "Blanco, negro y gris". En Edición especial de la Revista N, 25 años de democracia. Buenos Aires: Grupo Clarín.

- $\quad$ Bajtín, M. (1995). La cultura popular en la Edad Media y el Renacimiento. El contexto de François Rabelais. Madrid: Alianza.

- $\quad$ Bajtín, M. (1997). Estética de la creación verbal. México: Siglo XXI Editores.

- $\quad$ Bajtín, M. y Voloshinov V. (1998). ¿Qué es el lenguaje? La construcción de la enunciación. Ensayo sobre Freíd. Buenos Aires: Almagesto.

Bauman, Z. (2003). Comunidad. En busca de seguridad en un mundo hostil. Madrid: Siglo XXI. 
- $\quad$ Benveniste, E. (1997). Problemas de lingüística general II. España: Siglo XXI Editores.

- $\quad$ Beltrán Fuentes, R. (1989). La ideología antiautoritaria del rock. Buenos Aires: Centro Editor de América Latina.

Berlin, I. (2004). La traición de la libertad: seis enemigos de la libertad humana. España: Fondo de Cultura económica.

- Berti, E. (1994). Rockología, documentos de los '80. Buenos Aires: Beas Ediciones.

- $\quad$ Bertaux, D. (1989). "Los relatos de vida en el análisis social”. En Historia y fuente oral (Revista Semestral del Seminario de Historia Oral del Departamento de Historia Contemporánea de la Universidad de Barcelona, España, No. 1.

- Blanco, O. y Scaricaciottoli, E. (2014) Las letras de rock en Argentina. De la caída de la dictadura a la crisis de la democracia (1983-2001). Buenos Aires: Colihue.

- Blanco, O. (2012). "Un cóctel crítico. Un uso de la ciencia-ficción elaborado por las letras de rock producidas en Argentina". En Revista Iberoamericana, 78(238), 277-291.

- $\quad$ Bonnin, J. E. (2006). Análisis del discurso. Recuperado de la World Wide Web el, 27(06).

- Calsamiglia. H., \& Tusón, A. (1999). Las cosas del decir: manual de análisis del discurso. España: Ariel.

- $\quad$ Camou, A. (2007) "Se hace camino al transitar. Notas en torno a la elaboración de un discurso académico sobre las transiciones democráticas en Argentina y América Latina”. En Camou, A.; Tortti, C. y Viguera, A (Comp.). La Argentina Democrática: Los años y los libros. Buenos Aires: Prometeo.

- Cantilo, M. (2011). ¿Qué circo! - Memoria y presente de medio siglo de rock argentino. Buenos Aires: Editorial Galerna.

- Carnovale, V. (2013). “Nuestros años sesentas, cinco décadas después”. En Revista Quinto sol, 17(2), 11.

- Carbó, T. (2002). "El cuerpo herido o la constitución del corpus en análisis de discurso". En Revista Lenguaje. sociedad y discurso: una anamorfosis ante el nuevo milenio. México: uAM-Iztapalapa.

- Casciero, R. (2003). “Un nuevo viaje en la vida cambiante de La Portuaria”. En Diario Página/12. [en línea]. Consultado el 10 de octubre de 2016 en < http://www.pagina12.com.ar/diario/espectaculos/6-29501-2003-12-20.html 
- Cavarozzi, M. (1983). Autoritarismo y democracia (1955-1983) (Vol. 21). Buenos Aires: Centro editor de América latina.

- Charaudeau, P. (2004). "La problemática de los géneros: De la situación a la construcción textual”. En Revista signos, 37(56), 23-39

Charaudeau, P. (2009). "Discurso y Contexto". En Revista Discurso \& Sociedad,3(2), 253-279 [en línea]. Consultado el 10 de octubre de 2016 en < http://www.dissoc.org/ediciones/v03n02/DS3(2)Charaudeau.pdf $>$.

- $\quad$ Chastagner, C. (2012). De la Cultura Rock, Argentina: Paidós.

- $\quad$ Cibeira, J. M. (2014). La biblia del rock. Argentina: Paidós.

- Cicalese, R. y Nogueira, S. (1998). La música argentina en los períodos 1982/85 y 1993/97. Una misma geografía, dos visiones del mundo. En: "Treinta años de música joven”. Buenos Aires: Ediciones de la Flor.

- $\quad$ Ciccioli, M. (2010) Rockeado. Buenos Aires: Emecé.

- Conde, O. (2007) "La poesía del rock en la formación del docente de letras". Buenos Aires: Universidad de Buenos Aires [en línea]. Consultado el 10 de octubre de 2016

en

$<$ http://www.buenosaires.gob.ar/areas/educacion/docentes/superior/ponen/peje1_10.pdf $>$.

Conde, O. (2007). Poéticas del rock Vol I y II. Buenos Aires: Marcelo Héctor Oliveri Editor.

- Conde, O. (2007). "Poéticas del rock", en ADN Cultura, Revista La Nación, Buenos Aires, Grupo La Nación [en línea]. Consultado el 10 de octubre de 2016 en $<$ http://www.buenosaires.gob.ar/areas/educacion/docentes/superior/ponen/peje1_10.pdf

- $\quad$ Cohen, S. (1972). Folk Devils and Moral Panics. London: McGibbon and Kee.

- Correa, G. (2002). "El rock argentino como generador de espacios de resistencia”. En Revista de Artes y Diseño Huellas. Argentina, No 2, pp. 40-54

- $\quad$ Cubides, H., Toscano, M. C. L., Valderrama, C. E., \& Margulis, M. (1998). Viviendo a toda: jóvenes, territorios culturales y nuevas sensibilidades. Colombia: Siglo del Hombre Editores.

Conein, B. y Pecheux M. (1982). 'L' analyse de discours face aux matériaux sociologiques". En X Congreso Mundial de Sociología, RC, 25, Sesión 11: México DF. - $\quad$ D’Addario, F. (2008). “El formidable envión del '84”. En Página 12, especial 25 años de democracia. Buenos Aires [en línea]. Consultado el 10 de octubre de 2016 en $<$ http://www.pagina12.com.ar/diario/especiales/subnotas/18-37069-2008-12- 
10.html>.

- $\quad$ Denisoff, R. S. \& Mark L. (1971). "The one dimensional approach to popular music". En Joarnal of Popular Culture, 4.

Del Manzo B. y Martínez, M. (2014). “Aproximaciones a los estudios del discurso". En Cuadernos de Cátedra 2013. Cátedra Lingüística y Métodos de Análisis lingüísticos. Facultad de Periodismo y Comunicación Social. Universidad Nacional de La Plata: Edulp.

- Del Mazo, Mariano (2006). "El rock y después”. En Debates en la cultura argentina 2 (2005-2006). Buenos Aires: Emecé.

- De Amézola, G. (2011). "La última dictadura militar en la escuela Argentina: entre la historia reciente y la memoria colectiva". En Revista de Teoría y Didáctica de las Ciencias Sociales, (17), 29-56.

- $\quad$ De Garay, A. (1989). “Prelogómenos de la Cultura Rock”. En Estudios sobre la cultura contemporánea, Año/Vol II, Número 6, Universidad de Colima, México, p. 117-135.

- Delbueno, H (2009). "El rock nacional como herramienta contra-hegemónica: cambiando lo amargo por miel y la gris ciudad por rosas". En XIII Jornadas de Investigadores en Comunicación: "Itinerarios de la comunicación ¿Una construcción posible? San Luís.

- $\quad$ Debeljuh, P. (2003). El desafío de la Ética. Buenos Aires: Temas.

- Delfa, C. V. (2015). “Análisis enunciativo del género discursivo de la canción protesta: espacio de encuentro e interacción social". En Ogigia. Revista Electrónica de Estudios Hispánicos, (16), 71-82.

Diederichsen, D. (2010). Psicodelia y readymade. Buenos Aires: Adriana Hidalgo Editora.

- Di Marco, A. (1994). "Rock: universo simbólico y fenómeno social”. En Margulis, M (edit.) La cultura de la noche. La vida nocturna de los jóvenes en Buenos Aires. Buenos Aires: Espasa Calpe.

- Di Cione, L. (2006). El debut de Virus en el festival 'Prima Rock'. Conflicto en la escena musical a comienzos de los '80 en la Argentina. Buenos Aires: ISMP SADE.

- $\quad$ Dubois, J. (1979). Diccionario de lingüística. Madrid: Alianza.

- $\quad$ Ducrot, O. (1984) El decir y lo dicho, Buenos Aires: Editorial Hachette.

- Elizalde, S. (2009). "Normalizar ante todo. Ideologías prácticas sobre la identidad sexual y de género de los/as jóvenes en la dinámica de las instituciones 
orientadas a la juventud". En Revista argentina de estudios de juventud, 1(1) [en línea].

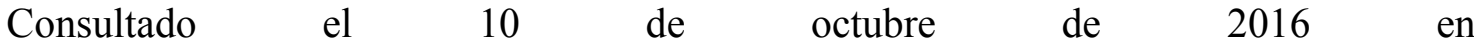

$<$ http://perio.unlp.edu.ar/ojs/index.php/revistadejuventud/article/view/1475 >.

- $\quad$ Fabregat, E. (2008). "Ninguna bala parará este tren”. En "Página/12, especial

25 años de democracia”, Buenos Aires [en línea]. Consultado el 10 de octubre de 2016 en $<$ http://www.pagina12.com.ar/diario/especiales/subnotas/18-37070-2008-12-10.html $>$.

- Fabris, M. y Tortorella, R. (2011). Democracia en reconstrucción. Mosaico histórico de los años ochenta. Mar del Plata: EUDEM, Editorial de la Universidad Nacional de Mar del Plata.

- $\quad$ Fasano, P., Jiménez, J., Ruiu, A. y Ramírez, A. (2002). “La realidad social como pieza comunicacional”. En VI Congreso Latinoamericano de Investigadores de la Comunicación. Santa Cruz de la Sierra.

Favoretto, M. (2014). Charly en el país de las alegorías: un viaje por las letras de Charly García. Buenos Aires: Gourmet Musical Editora.

Feld, C., \& Franco, M. (2015). Democracia y derechos humanos en 1984, ¿hora cero? En Feld, C. y Franco, M. (edas.) Democracia, hora cero. Actores, políticas y debates en los inicios de la posdictadura. Buenos Aires: Fondo de Cultura Económica.

- $\quad$ Feixa, C. (1998). De jóvenes, bandas y tribus. Antropología de la juventud. Barcelona: Editorial Ariel.

- $\quad$ Fernández Bitar, M. (1987) M. La historia del rock argentino, Buenos Aires: Distal.

Ferrari, A. y Herrera, F. (1987). Los hombres del presidente. Buenos Aires: Ediciones Tarso.

- $\quad$ Ferrari, G. y Pérez, J. (2013). 1983: el año de la democracia. Buenos Aires: Editorial Planeta.

- $\quad$ Ferris Graves, B. y McBain, D. (1972). Lyrical Voices: approaches to the poetry of contemporary song. New York: John Wiley.

- Fino, C. (2006). "Reflexiones sobre el punto de vista del investigador en el Análisis del Discurso". En Revista Tram[p]as de la Comunicación y la Cultura. Facultad de Periodismo y Comunicación Social. UNLP [en línea]. Consultado el 10 de $\begin{array}{llll}\text { octubre } & \text { de } & 2016 & \text { en }\end{array}$ $<$ http://sedici.unlp.edu.ar/bitstream/handle/10915/34034/Documento_completo.pdf?seq uence $=1>$. 
- Firbas, J. (1992). Functional sentence perspective in written and spoken communication. Cambridge: Cambridge University Press.

- $\quad$ Ford, A. (1996). Navegaciones: Comunicación, cultura y crisis. Buenos Aires: Amorrortu Editores.

- $\quad$ Frith, S. (1987) "Towards an aesthetic of popular music". En Richard Leepert y Susan McClary (eds.) The politics of composition, performance and reception. Cambridge: Cambridge University Press.

- $\quad$ Frith, S. (2014). Ritos de la interpretación: sobre el valor de la música popular. España: Grupo Planeta.

- García, D. (2009). "El lugar de la autenticidad y de lo undergorund en el rock", en Revista Nómadas. Bogotá.

- $\quad$ Gargarella, R., Murillo, M. V., \& Pecheny, M. (2013). Discutir Alfonsín. Siglo XXI Ed.

- Garrote, V. (2006). "La estrategia de la alegría: la configuración queer en el underground de los 80”. Nueva Jersey: Rutgers Universit [en línea]. Consultado el 10 de octubre de 2016 en $<$ https://rucore.libraries.rutgers.edu/rutgers-lib/41771/>.

- Giberti, E. (1998). "Hijos del rock". En Cubides, H., Toscano, M. C. L., Valderrama, C. E., \& Margulis, M. (comp.). Viviendo a toda. Jóvenes, territorios culturales y nuevas sensibilidades. Colombia: Universidad central - DIUC - Siglo de hombres editores.

- Guerrero, G. (1994). La historia del palo: diario del rock argentino, 1981-1984. Buenos Aires: Ediciones de la Urraca.

- Grinberg, M. (1985) "Comentario de Miguel Grinberg”. En Jelin, Elizabeth (comp.): Los nuevos movimientos sociales/1. Buenos Aires: CEAL.

- $\quad$ Grossberg, Lawrence (1984). "Rock and roll and the empowerment of everyday life". En Magazine Popular Music, Vol: 4.

- $\quad$ Guber, R. y Visacovsky, S. E. (2005). “CCrisis o transición? Caracterizaciones intelectuales. Del dualismo argentino en la apertura democrática". Anuario de estudios americanos, 62(1).

- $\quad$ Halliday, M y Ch. Mathiessen. (2004). An Introduction to Functional Grammar. London: Arnold.

- Hebdige, D. (2003). Subcultura, el significado del estilo. Barcelona: Editorial Paidós. 
- $\quad$ Hesmondhalgh, D. (2015). ¿Por qué es importante la música? España: Paidós.

- Herrera, L. G., Sandoval, S. Á., \& Serrano, E. B. (2009). "El desarrollo institucional del liberalismo y su planteamiento económico en el siglo XIX”. En revista Análisis Económico, 24(56).

- $\quad$ Hilb, C. (2013). Usos del pasado. Buenos Aires: Siglo XXI.

- Hidalgo Downing, R. 2003. La tematización en el español hablado. Estudio discursivo sobre el español peninsular. Madrid: Gredos.

- Huyssen, A. (2002). Después de la gran división: Modernismo, cultura de masas, posmodernismo. España: Adriana Hidalgo.

- $\quad$ Iñiguez Rueda, L. (2003) Análisis del discurso. Manual para las Ciencias Sociales. Barcelona: Editorial UOC.

- Jakobson, R. (1960). "Lingüística y Poética”, en Ensayos de lingüística general. Barcelona: Editorial Ariel.

- Jameson, F. (1999). El giro cultural. Buenos Aires: Manantial.

- Jelin. E. (1995), "La política de la memoria: el movimiento de Derechos Humanos y la constitución de la democracia en la Argentina”. En Landi, O. Juicio, castigos y memorias. Derechos Humanos y Justicia en la politica argentina. Buenos Aires: Nueva Visión.

- Kaufman, S. (2014). "Violencia y testimonio. Notas sobre subjetividad y los relatos posibles". En Clepsidra. Revista Interdisciplinaria de Estudios sobre Memoria, 1(1), 100-113.

- Keightley, Keir (2006) "Reconsiderar el rock”, en Frith, S. Straw, W. y Street, J. (Comp.) La otra historia del rock, Barcelona: Ediciones Robinbook.

- Kerbrat-Orecchioni, C. (1983). La connotación, Buenos Aires: Editorial Hachette.

- Kerbrat-Orecchioni, C. (1986). La enunciación. Buenos Aires: Editorial Hachette.

- Koch, K. (2008). “Gustavo Cerati. La vidriera posmoderna”. En Poéticas del rock Vol. 2. Buenos Aires: Marcelo Héctor Olivieri Editor.

- Kozak, C. (1990). Rock en Letras. Buenos Aires: Editorial Libros del Quirquincho, Colección Libros para Nada.

- $\quad$ Kreimer, J. C., Polimeni, C., Pintos, G., \& Núñez, G. Á. (2006). Ayer nomás: 40 años de rock en la Argentina. Buenos Aires: Musimundo. 
- $\quad$ Kriger, M. (2010). Jóvenes de escarapelas tomar. La Plata: EDULP.

- Kriger, M. (2013). “Creencias y valoraciones de la política, entre jóvenes argentinos desde el 2010: hallazgos de un estudio empírico realizado en buenos aires y alrededores". En V Congreso Internacional de Investigación y Práctica Profesional en Psicología XX Jornadas de Investigación Noveno Encuentro de Investigadores en Psicología del MERCOSUR. Facultad de Psicología-Universidad de Buenos Aires.

- $\quad$ Laclau, E. (2005). La razón populista. Buenos Aires: Siglo XXI.

- Landi, O. (1984). “Cultura y política en la transición a la democracia”. En Revista Nueva Sociedad. Caracas. Julio/Agosto, 65-78.

- $\quad$ Larraín Contador, R. (1998). “La posmodernidad como obra de los hippies”. En Revista Catalanes. Barcelona, 137-148.

- Lechner, N. (1990). "De la revolución a la democracia". En "Debate feminista", 1, 29-45.

Leikis, A. (2016). "Los Tipitos presentaron su nuevo álbum "Ojos Tremendos”. En página web Entremelodias.com [en línea]. Consultado el 10 de octubre de 2016 en $<$ http://entremelodias.com/post/146895788371/los-tipitos-presentaron-sunuevo\% $\%$ C $\%$ A1lbum-ojos>.

Lesgart, C. (2003). Usos de la transición a la democracia: Ensayo, ciencia y política en la década del '80. Buenos Aires: Homo Sapiens Ediciones.

- Levín, F. (2007). "El pasado reciente en la escuela, entre los dilemas de la historia y la memoria”. En Schujman, G. y Siede. I (coords.), Ciudadanía para armar. Apuntes para la formación ética y política. Buenos Aires: Aique.

- $\quad$ Levinson, S. (1983). Pragmática. Barcelona: Teide.

- $\quad$ Lipovetsky, G. (1993). La era del vacío. Barcelona: Anagrama.

- $\quad$ Locke, J. (1994). Segundo tratado sobre el gobierno civil. España: Altaya.

- $\quad$ Londoño Zapata O. (2012). Poliedros discursivos: Miradas de los Estudios del Discurso. Córdoba: ALED.

López, E. (1994). Ni la ceniza ni la gloria: actores, sistema político y cuestión militar en los años de Alfonsín. Universidad Nacional de Quilmes.

- $\quad$ Louge, J. (2008). "Fito Páez. Poética canalla”. En Poéticas del rock Vol. 2. Buenos Aires: Marcelo Héctor Olivieri Editor.

- $\quad$ Lupo, T. (2006). "El rock y después". En Debates en la cultura argentina 2 (2005-2006. Buenos Aires: Emecé. 
- Maingueneau, D., \& Charaudeau, P. (2005). Diccionario de análisis del discurso. Buenos Aires: Amorrortu.

- Maingueneau, D. (2010) Análisis de textos de comunicación. Buenos Aires: Nueva Visión.

- Manzano, V. (2010). "Juventud y modernización sociocultural en la Argentina de los sesenta”. En Revista Desarrollo Económico, N 5. 363-390.

- Marafioti, R. (1998). Signos, enunciación y argumentación. Buenos Aires: Eudeba.

- Marchi, S. (2005). El Rock Perdido. Buenos Aires: Editorial Ediciones Le monde Dilomatiqué.

- Margulis, M., \& Ariovich, L. (1996). La juventud es más que una palabra: ensayos sobre cultura y juventud. Buenos Aires: Editorial Biblos.

- $\quad$ Marín, M. (2008). Teoría de la lectura como proceso. Lingüistica y enseñanza de la lengua. Buenos Aires: Aique.

- $\quad$ Mascia, M. J. (2008). “Andrés Calamaro. Una poética confesional”. En Poéticas del rock Vol. 2. Buenos Aires: Marcelo Héctor Olivieri Editor.

- $\quad$ Mazzina, C. (2007) “QQué es la libertad?”. En Revista Laissez-Faire, № 26-27. Guatemala: Universidad Francisco Marroquín.

- Meunier J. C. (1981). La Estudiantina Universitaria. Entrevista Personal. Cabimas, Zulia (Venezuela).

- $\quad$ Mill, J. S. (2005). Sobre la libertad. Buenos Aires: Edaf.

- $\quad$ Minelli, M. A. (2010). “Algunas formas menores en la cultura argentina de fines del siglo XX”. En Revista Astrolabio.

- Molina, C. (2008). “Sumo. El mundo moderno según Prodan”. En Poéticas del rock Vol. 2. Buenos Aires: Marcelo Héctor Olivieri Editor.

- Monteleone, J. (2002). "Figuras de la pasión rockera: Ensayo sobre rock argentino" [en línea]. Consultado el 10 de octubre de 2016 en $<$ http://www.eter.org/everba/summer02/figuras_jorge.html $>$.

- $\quad$ Montesquieu, C. L. de S. (1972). Del espíritu de las leyes. Madrid: Tecnos.

- $\quad$ Moura, M. (2014). Virus. Buenos Aires: Editorial Planeta.

- Narvaja de Arnoux, E. (2006). Análisis del discurso. Modos de abordar materiales de archivo. Buenos Aires: Santiago Arcos editor. 
- Novaro, M., \& Palermo, V. (2004). La historia reciente: Argentina en democracia. Buenos Aires: Edhasa.

- $\quad$ Novaro, M., \& Novaro, M. (2006). Historia de la Argentina contemporánea. Buenos Aires: Edhasa.

- Ollier, M. M. (2009). De la revolución a la democracia: cambios privados, públicos y políticos de la izquierda argentina. Buenos Aires: Siglo Veintiuno Editores.

- O’Donnel, G. y Schmitter, P. (2010). Transiciones desde un gobierno autoritario/4. Conclusiones tentativas sobre las democracias inciertas. Barcelona: Paidós.

- Ordóñez, S. (1997). Temas, remas, focos, tópicos y comentarios (Vol. 46). España: Arco Libros.

- $\quad$ Parret, H. (1983). Semiótica y Pragmática. Una comparación evaluativa de marcos conceptuales. Buenos Aires: Gedisa.

- $\quad$ Parret, H. (1987) “Las temporalidades de lo cotidiano”. En Revista Morphé. Núms. 3-4. Puebla: Centro de Investigación y Docencia en Ciencias del Lenguaje, Universidad Autónoma de Puebla.

- Pasquini Durán, J. M. (1995). Ilusiones argentinas. Un relato de ideas. Argentina: Editorial Planeta.

- $\quad$ Patterson, O. (1993). La libertad: la libertad en la construcción de la cultura occidental. España: Andrés Bello.

- Pavel, T (1995). Mundos de ficción. Venezuela: Monte Ávila Editores Latinoamericana.

- $\quad$ Pérez Islas, J. A. (1998). “Memorias y olvidos. Una revisión sobre el vínculo de lo cultural y lo juvenil". En Cubides, H., Toscano, M. C. L., Valderrama, C. E., \& Margulis, M (comp). Viviendo a toda. Jóvenes, territorios culturales y nuevas sensibilidades. Colombia: Siglo de hombres editores.

- $\quad$ Perelman, C. (1989). Tratado de la argumentación. La nueva retórica. Madrid: Gredos.

- $\quad$ Paraire, P. (1992). 50 años de música rock. España: Ediciones del Prado.

- $\quad$ Pérez, R. G. (1994). El rock: historia y análisis del movimiento cultural más importante del siglo $X X$. Colombia: Ediciones Tutor, SA.

- Plaza, G. (2015). “Celeste Carballo: la reina del blues argentino”. Diario La Nación. Buenos Aires. Grupo La Nación. [en línea]. Consultado el 10 de octubre de 2016 en $<$ http://www.lanacion.com.ar/1832921-celeste-carballo-la-reina-del-blues- 
$\operatorname{argentino}>$.

- $\quad$ Portantiero, J. C (1997). Política social y democracia: la experiencia del Cono Sur. Buenos Aires. Universidad Nacional de Quilmes.

Provéndola, J.I. (2015). Rockpolitik: 50 años del rock nacional y sus vínculos con el poder político argentino. Buenos Aires: Editorial Eudeba.

- $\quad$ Pujol, S. y Satas H. (2002). La década rebelde: los años 60 en la Argentina. La Plata: Emecé Editores.

- $\quad$ Pujol, Sergio (1999). La historia del baile. Buenos Aires: Editorial Emecé.

- $\quad$ Pujol, Sergio (2005). Rock y dictadura. Buenos Aires: Editorial Emecé.

- $\quad$ Pujol, Sergio (2007). Las ideas del rock. Buenos Aires: Editorial Homo-sapiens.

- $\quad$ Pujol, Sergio (2010). Canciones argentinas 1910-2010. Buenos Aires: Editorial Planeta.

- $\quad$ Quintana, D. C., \& de la Puente, E. (1996). Todo vale: antología analizada de la poesía rock argentina desde 1965. Buenos Aires: Distal.

- $\quad$ Ramírez Peña, L. A. (2008). "Polifonía y dialogismo en el discurso". En Hechos y proyecciones del lenguaje. Colombia: Centro de publicaciones de la Universidad de Nariño.

- $\quad$ Reano, A. y Smola, J. (2013). “30 años de democracia. Debates sobre los sentidos de la política en la transición argentina". En Estudios: Centro d Estudios Avanzados, (29), 35-51.

- Reguillo. R. (2000). Emergencia de culturas juveniles: estrategias del desencanto. México: Editorial norma.

Reynolds, S. (2013). Postpunk: romper todo y empezar de nuevo. Buenos Aires: Caja negra editora.

- $\quad$ Ricour, P (1986). Política, sociedad e historicidad. Buenos Aires: Prometeo.

- Riera, D. y Sánchez, F. (1995). Virus. Una generación. Buenos Aires: Sudamericana.

- $\quad$ Rinesi, E. (2013). “Artículos centrales”. Publicación de Ciencias Sociales que lleva adelante la Carrera de Trabajo Social de la Facultad de Ciencias Sociales de la Universidad de Buenos Aires, con el objetivo de generar un espacio de debate y difusión de conocimiento social., 27.

- $\quad$ Robin, R. (1994). "Para una sociopoética del imaginario social”. En: Perus, F. (comp.). Literatura e historia (pp. 262-300). México: Instituto de Investigaciones José 
María Mora.

- $\quad$ Romero, L. A. (1999). Breve historia contemporánea de la Argentina. Buenos Aires: Fondo de Cultura Económica.

- $\quad$ Rousseau, J. J. (1965). El contrato social. España: Consuelo Berges.

- $\quad$ Rozitchner, A. (2003). Escuchá que tema. Buenos Aires: Editorial Planeta.

- $\quad$ Sampedro, O. V. (2009). "El rock y la modernidad: hacia una nueva experiencia". En La Colmena, (61/62), 66-73.

- $\quad$ Sanz Ferramola, R. (2009) “¿Tiene moral el rock?”. En Yo no permito: rock y ética en Argentina durante la última Dictadura. San Luis: Derechos Humanos Colección. Nueva Editorial Universitaria.

Sartori G, (1979). "Liberty and Law". En Templeton, K. Jr. (comp.), The Politicization of Society. Liberty Press: Saavedra y Cabrera.

- Saintout, F. J. S. (2006). Jóvenes: el futuro llegó hace rato: comunicación y estudios culturales latinoamericanos (No. 316.62/. 64). Universidad Nacional de La Plata.

- Salvi, V. (2009). "De vencedores a víctimas: 25 años de memoria castrense". En Temas y debates, (17), 93-115.

- Scatolini, J. C. (2011). El pasaje del hombre de la sociedad moderna a la posmoderna. Anales de la Facultad de Ciencias Jurídicas y Sociales, 8.

- $\quad$ Secul Giusti, C. E. \& Rodríguez Lemos, F. (2011). Si tienes voz, tienes palabras: análisis discursivo de las líricas del rock argentino en la "primavera democrática" (1983-1986). Tesis de Grado. Facultad de Periodismo y Comunicación Social.

- Secul Giusti, C. E. (2013). "Sólo déjennos bailar: cuerpo, liberación y consolidación democrática en el rock argentino de la década del ochenta". En Jornadas de Periodismo, Política y Comunicación: 30 años de Democracia. La Plata: Universidad Nacional de La Plata.

- $\quad$ Secul Giusti, C. E. (2014). "El rock argentino y la postulación de la libertad durante el período 1982-1989, entre simulacros y autenticidades”. En VIII Jornadas de Sociología de la UNLP. La Plata: Universidad Nacional de La Plata

- $\quad$ Secul Giusti, C. E. (2014). "El Rock de la jaula: la Fricción de Don Cornelio”. En Revista Question. La Plata: Universidad nacional de La Plata

- $\quad$ Secul Giusti, C. E. (2015). "Rock argentino y tendencia pop durante el período 1982-1989”. En Revista Letras. La Plata: Centro de Lectura y Escritura (CILE) de la Facultad de Periodismo y Comunicación Social de la Universidad Nacional de La Plata 
- Semán, Pablo (2006) "Vida, apogeo y tormentos del rock chabón”. En Bajo continuo. Exploraciones descentradas sobre cultura popular y masiva. Buenos Aires: Editorial Gorla.

- $\quad$ Semán, Pablo y Vila, Pablo (1999) "Rock Chabón e Identidad Juvenil en la Argentina Neo-Liberal”. En: Filmus, D. (comp.), Los Noventa: Política, Sociedad y Cultura en América Latina y Argentina de fin de siglo. FLACSO: Buenos Aires.

- $\quad$ Seoane, M. (2004). Argentina: el siglo del progreso y la oscuridad (1900-2003). Buenos Aires: Crítica.

- $\quad$ Seoane, M. (2008). Amor a la argentina. Sexo, moral y política en el siglo XXI. Buenos Aires: Editorial Planeta.

- Shapiro, P. (2012). La historia secreta del disco: sexualidad e integración racial en la pista de baile. Buenos Aires: Caja Negra.

- $\quad$ Sierra i Fabra, J. S. (2003). La era rock (1953-2003). España: Calpe.

- $\quad$ Suriano, J., y Álvarez, E. (2013). 505 días que la Argentina olvidó. Buenos Aires: Sudamericana.

- $\quad$ Szulik, D., y Kuasñosky, S. (1996). “Jóvenes en la mira”. En La juventud es más que una palabra, Margulis, Mario (editor). Buenos Aires: Editorial Biblos.

- $\quad$ Todorov T. y Ducrot O. (1984). Diccionario Enciclopédico de las Ciencias del lenguaje, Buenos Aires: Siglo XXI.

- $\quad$ Ulanovsky, C. (2008). 25 voces de la democracia. Buenos Aires: Presidencia de la Nación.

- Van Dijk, T. (1978). La ciencia del texto. España: Gedisa.

- Van Dijk, T. (1999). "El análisis crítico del discurso". Revista anthropos: Huellas del conocimiento, (186), 23-36.

- Van Dijk, T. (2001) El análisis crítico del discurso y el pensamiento social. Universidad Pompeu Fabra: Editorial Atenea Digital.

- Van Dijk, T. (2002). “El Análisis Crítico del Discurso”. En Revista Anthropos. Barcelona.

- Van Dijk, T. (2004). “Discurso y dominación”. En Grandes conferencias en la Facultad de Ciencias Humanas, 4, 5-28.

- Vezzetti, H. (2002) Pasado y presente. Guerra, dictadura y sociedad en la Argentina. Buenos Aires: Siglo XXI.

- Valentino, A., \& Fino, A. (2015). La información como discurso. Recorridos 
teóricos y pistas analíticas. Facultad de periodismo y comunicación Social. Universidad Nacional de la Plata: Edulp.

- Vila, Pablo (1985) “Rock nacional, crónicas de la resistencia juvenil”. En Jelin, Elizabeth (comp.). Los nuevos movimientos sociales/1. Buenos Aires: CEAL.

Viñas, R. (2015). Tesis Doctoral " Ser joven, leer y escribir en la Universidad. Las prácticas de lectura y escritura: de la escuela secundaria a la universidad". La Plata: Facultad de Periodismo y Comunicación Social, UNLP. [en línea]. Consultado el 15 de mayo de 2016 en: http://sedici.unlp.edu.ar/handle/10915/44649

- $\quad$ Vommaro, P. (2013). "Las relaciones entre juventudes y políticas en la América Latina contemporánea: una aproximación desde los movimientos estudiantiles". En Revista Sociedad, 32, 127-144.

Wodak R. y Meyer M. (2003) “Métodos de análisis crítico del discurso”, en Van Dijk. T. (coord.). La multidisciplinariedad del análisis crítico del discurso: un alegato en favor de la diversidad. Teun Van Dijk. Barcelona: Editorial Gedisa.

Yepes Stork, R. (1997). La persona y su intimidad. España: Cuadernos de Anuario Filosófico.

\section{Revistas y suplementos}

- $\quad$ Aguirre, J. (2012), "Pozo guerrillero irascible", Suplemento No, Página/12, Argentina [en línea]. Consultado el 10 de octubre de 2016 en $<$ http://www.pagina12.com.ar/diario/suplementos/no/12-5907-2012-04-19.html >.

Andrade, J. (2010). “El rock del crepúsculo”, en Suplemento Radar, Página/12, Argentina [en línea]. Consultado el 10 de octubre de 2016 en < http://www.pagina12.com.ar/diario/suplementos/radar/9-6436-2010-09-05.html >.

- $\quad$ Berti, E. (1986). “El sonido del silencio”. En Revista Canta-rock, Año 4, Nro. 74.

Cibeira, J. M. (1985). “Nuevas armonías”. En Revista Pelo, Año 15, No 245, Buenos Aires.

Conte, S. (1995). "Sueter contraataca: no te pongas traje...". En Revista Pelo. Año $25 . \mathrm{N}^{\circ} 479$.

- Dillon, M y Riera. D. (2000). “El rock al poder: Epúmer \& Lopérfido”. En Revista Rolling Stone. N 15. Buenos Aires: Grupo La Nación. 
- Jalil, O. (2016). "Palo Pandolfo: mi vida en 20 canciones". En Revista Rolling Stone. Año 18. Número 216.

- $\quad$ Lernoud, P. (1984). “Un puñetazo con humor”. En Revista Canta-rock. Año 2. Número 16.

- Lescano, V. (2008). "Rockera total”. En Suplemento Soy del Diario Página/12 [en línea]. Consultado el 10 de octubre de 2016 en < http://www.pagina12.com.ar/diario/suplementos/las12/13-3883-2008-02-03.html>.

- Marchi, S. (1988). "Entrevista: fricción”. En Revista Rock and Pop [en línea]. $\begin{array}{lllllll}\text { Consultado el } & \text { el } & \text { de } & \text { octubre } & \text { de } & 2016 & \text { en }\end{array}$ $<$ http://instantesdecielo.blogspot.com.ar/2009_05_01_archive.html>.

- $\quad$ Mercuri, A. (1986). "Metrópoli: algo profundo bajo la máscara". Revista Pelo, Año 16, Nro. 272, pp. 16-17.

- Pérez Castillo, E. (2013). "La hiedra de muchas cabezas”. Diario Página/12 [en línea]. Consultado el 10 de octubre de 2016 en $<$ http://www.pagina12.com.ar/diario/suplementos/rosario/12-40553-2013-09-13.html>. - Revista Canta-rock. (1985). "Los Abuelos de la Nada”. Especial 20 años de rock nacional: la enciclopedia total. Año 2. Número 37, p. 20.

- Revista Canta-rock. (1985). "El grito sagrado". Especial 20 años de rock nacional: la enciclopedia total. Año 2. Número 37, p. 22.

- Revista Canta-rock. (1985). "La verdad de abajo". Especial 20 años de rock nacional: la enciclopedia total. Año 2. Número 37, p. 42.

Revista Canta-rock. (1985). "Los Twist”. Especial 20 años de rock nacional: la enciclopedia total. Año 2. Número 37, p. 59.

Revista Canta-rock. (1985). "Charly García". Especial 20 años de rock nacional: la enciclopedia total. Año 2. Número 37, p. 60-61.

- $\quad$ Revista Canta-rock. (1985). "La Torre”. Especial 20 años de rock nacional: la enciclopedia total. Año 2. Número 37, p. 63.

- $\quad$ Revista Canta-rock. (1985). "Fito Páez". Especial 20 años de rock nacional: la enciclopedia total. Año 2. Número 37, p. 65.

- $\quad$ Revista Rolling Stone (2002). "Los 100 hits del rock argentino”. Buenos Aires: Grupo La Nación. Año 5. Número 48.

- $\quad$ Revista Rolling Stone (2007). "Edición especial. 100 mejores discos del rock nacional”. Buenos Aires: Grupo La Nación. Año 10. Número 109. 
- $\quad$ Revista Rolling Stone (2015). “Charly García. 100 mejores canciones”. Buenos

Aires: Grupo La Nación. Año 15. Número 207.

- $\quad$ Revista Rock and Pop (1988). “Crítica de discos”. Año 2. Número 17, p. 25.

Revista Rock and Pop (1989). “Crítica de discos”. Año 3. Número 32, p. 27.

- $\quad$ Schanton, P. (1999), "Fuimos víctimas de la cultura menemstone”. Suplemento Sí.

Clarín [en línea]. Consultado el 10 de octubre de 2016 en $<$ http://edant.clarin.com/suplementos/si/99-08-06/nota_3.htm.>.

- $\quad$ Schanton, P. (2008). "Virus, leyendas del rock". Especial Suplemento Si. Buenos Aires: Grupo Clarín.

\section{Sitios de Internet}

http://agftv.blogspot.com.ar/2012/01/revista-cantarock-varios-numeros-para.html http://www.billboard.com/

http://www.cmtv.com.ar/

http://www.efeeme.com/

$\mathrm{http}: / / w w w . e l a c o p l e . c o m / w p /$

http://instantesdecielo.blogspot.com.ar/

http://www.lahistoriadelrock.com.ar/

http://www.lanacion.com.ar/edicion-impresa/suplementos/ideas

http://www.losinrocks.com/

https://www.pagina12.com.ar/suplementos/radar/notas

http://www.revistaenie.clarin.com/

https://revistasdemusica.wordpress.com/

http://revistasoyrock.com.ar/

http://www.rock.com.ar/

http://www.rocktails.com.ar/

http://www.rollingstone.com.ar/

https://www.sadaic.org.ar/

\section{Bibliografía cancionística}

1982 "Inconsciente colectivo", Charly García: Yendo de la cama al living.

1982 “Ahora estoy en libertad”, Celeste Carballo: Me vuelvo cada día más loca. 
1982 "Una canción diferente”, Celeste Carballo: Me vuelvo cada día más loca.

1982 "Ir a más", Los Abuelos de la Nada: Los abuelos de la nada.

1982 "Buenos cimientos", La Torre: La Torre.

1983 "Yo soy tu bandera", Los abuelos de la Nada: Vasos y besos.

1983 "Su, me robaste todo", Zas: Huevos.

1983 “No me dejan salir", Charly García: Clics Modernos.

1983 "Viaje a la libertad", La Torre: Viaje a la libertad.

1983 "Ellos nos han separado", Virus: Agujero interior.

1983 “Jugando Hulla-Hulla”, Los Twist: La dicha en movimiento.

1984 "Libertad de pensamiento", Alejandro Lerner: Lernertrés

1984 "Demoliendo hoteles", Charly García: Piano bar.

1984 “Donde estás guardada?”, María Rosa Yorio: Por la vida.

1984 "Manifestación de escépticos", Sueter: Lluvia de gallinas.

1984 "Dietético", Soda Stereo: Soda Stereo.

1985 “Sin Disfraz", Virus: Locura.

1985 "Foto de una jaula", Sueter: 20 caras bonitas.

1985 “Alguna vez voy a ser libre”, Fito Páez: Giros.

1985 "Soy donde voy", GIT: GIT II

1986 "Hay que hacer la cola”, Viudas e Hijas de Roque Enroll: Ciudad Catrúnica.

1986 “Acción y reacción”, La Sobrecarga: Sentidos congelados.

1986 “Héroes anónimos”, Metrópoli: Viaje al más acá.

1986 “Nunca podrás sacarme mi amor”, Fito Páez: Corazón Clandestino.

1986 "Prófugos", Soda Stereo: Signos.

1986 "Nada me detiene", La Torre: Presas de caza.

1986 "Planeta Agua", Los Encargados: Silencio.

1986 “Los viejos vinagres”, Sumo: Llegando los monos.

1987 “Libre vivir”, Miguel Mateos: Solos en América.

1987 “El rosario en el muro", Don Cornelio y la Zona: Don Cornelio y la Zona.

1987 “Yo no me sentaría en tu mesa”, Los Fabulosos Cadillacs: Yo te avisé!!

1987 “Rodillas”, María Rosa Yorio: Rodillas.

1988 “Siento llegar”, Fabiana Cantilo: Fabiana cantilo y los perros calientes.

1988 “Guitarras blancas”, Los Enanitos Verdes: Carrousel.

1988 “Ocho ríos”, Los Pericos: King Kong.

1988 “Enjaulados”, Fricción: Para terminar. 
1988 “Espirales”, Don Cornelio: Patria o muerte.

1988 “Salgamos a la calle”, Man Ray: Man Ray.

1988 "No me empujes", Andrés Calamaro: Por mirarte.

1989 "Edificios", La Portuaria: Rosas rojas. 


\section{Anexo}

\section{Corpus de letras}

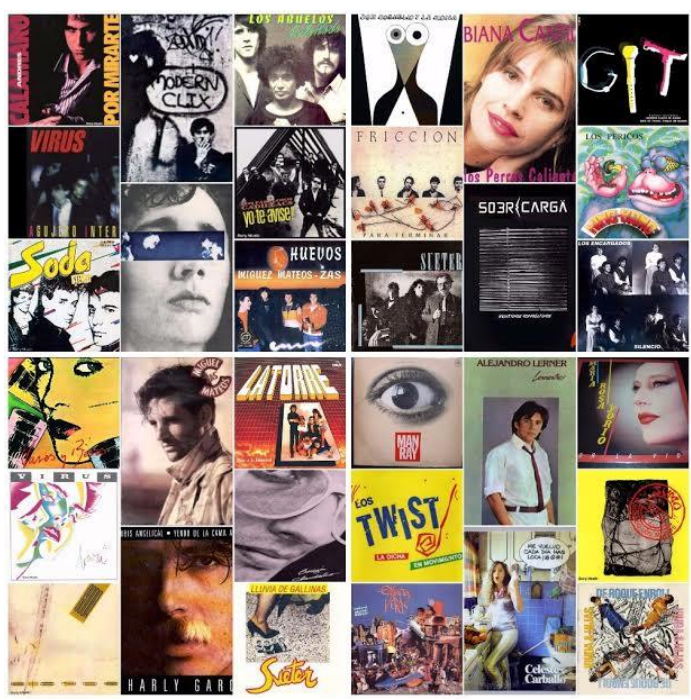

\section{"Inconsciente Colectivo"}

\section{Charly García}

\section{Letra: Charly García}

Yendo de la cama al living (1982)

Nace una flor, todos los días sale el sol, de vez en cuando escuchas aquella voz.

Cómo de pan, gustosa de cantar, en los aleros de mi mente con las chicharras.

Pero a la vez existe un transformador que te consume lo mejor que tenés, te tira atrás, te pide más y más y llega un punto en que no querés.

Mama la libertad, siempre la llevarás dentro del corazón.

Te pueden corromper, te puedes olvidar, pero ella siempre está.

Mama la libertad, siempre la llevarás dentro del corazón.
Te pueden corromper, te puedes olvidar pero ella siempre está.

Ayer soñé con los hambrientos, los locos, los que se fueron, los que están en prisión. Hoy desperté cantando esta canción que ya fue escrita hace tiempo atrás. Es necesario cantar de nuevo, una vez más.

\section{"Ahora estoy en libertad"}

\section{Celeste Carballo}

\section{Letra: Celeste Carballo}

Me vuelvo cada día más loca (1982)

Creo que estoy en libertad para sentir y para amar.

Creo que tengo lo que pedí, no me lo dieron, yo lo conseguí. $\mathrm{Y}$ aunque ahora siento un poco de frío, creo que el tiempo me traerá el abrigo.

Pero ahora estoy en libertad ahora estoy en libertad.

Me gustaría meterte en mi alma me gustaría estar tan enamorada que no me queden las ganas ni el tiempo, deshacerte de abrazos de dulzura y deseo. Pero no quiero nunca más las cadenas, 
porque ya vi, ya vi,

eso es una condena.

Por eso ahora,

quiero estar en libertad.

El miedo nos quita de a poco la vida.

La calle está dura nena, nena.

Hay pocas salidas.

¡Dios mío! No pierdan el tiempo

hablando de más.

No pierdan el tiempo

hablando de más.

Si ahora estoy en libertad,

si ahora estoy en libertad.

Todos los que dicen que mi vida es dudosa porque no hago como todos las cosas.

¡Dios mío! ¡Cómo pierden el tiempo!

Hablando de más,

pierden el tiempo

hablando de más.

Si ahora estoy

en libertad.

Si ahora estoy

en libertad.

\section{"Una canción diferente"}

Celeste Carballo

Letra: Celeste Carballo

Me vuelvo cada día más loca (1982)

Dame amor,

dame tu corazón.

Dame tiempo para respirar.

Está muriéndose el sol, dame música para crear,

una nueva canción.

Se abre despacio en el medio de la jungla, son nuestras voces que se escuchan juntas.

Dame amor,

estoy de muy mal humor.

Me revolqué por la realidad y ahora estoy destruida, necesito tu amor.

Ya no me aguanto una mentira más, yo con mi cuerpo de mujer voy a dar la verdad.

Si todo el mundo vive haciéndonos la guerra, yo necesito que me des tu paz.

Necesito arrancar todo lo que me hiera.

Necesito amor, necesito más, más libertad.

Necesito arrancar todo lo que me hiera.

Necesito amor, necesito más.

Necesito arrancar todo lo que mi hiera.

Necesito amor, necesito más... más libertad, Más libertad..

\section{"Ir a más"}

\section{Los Abuelos de La Nada}

Letra: Miguel Abuelo

Los Abuelos de la Nada (1982)

Ahí vas mi dueña.

Hoy me haces sentir, que en los nuevos tiempos hay que compartir. 
Voy cantando,

voy amando,

voy jugando,

voy a más.

Si Buenos Aires despierta,

yo digo se despereza.

Siente libertad

busca la alegría de ir a más.

Ruge mi moto, nena.

Voy a tu garaje.

Vos sos tan loca y buena,

yo quiero ir a más.

Si mi máquina es veloz,

será porque pienso en llegar.

Si Buenos Aires despierta,

yo digo yo digo se despereza.

Siente libertad,

busca la energía de ir a más.

Ven a mi banda nena,

no te hagas rogar.

No te ates a sistemas,

te atragantarás.

Ven cantando, ven bailando, ven jugando, ven a más.

Si Buenos Aires despierta, yo digo yo digo se despereza.
Siente libertad, busca la alegría de ir a más.

\section{"Buenos Cimientos"}

\section{La Torre}

\section{Letra: Oscar Mediavilla-Patricia Sosa}

\section{La Torre (1982)}

Para bien o para mal siempre saben la respuesta.

No te dejan el consuelo de decir: "la vida es nuestra".

Vamos a gritar nuestra libertad.

No dejes mover todos tus cimientos.

Caminando por la calle

vi a un tipo muy formal, que miraba a todo el mundo diciendo: "todo esto esta mal".

Pero yo, que leo la mente, deletreé en su interior cómo se sacaría el traje y cantaría un rock and roll. Intentamos, por lo menos, no dejar caer a todos.

Los que saben la respuesta ya no están entre nosotros.

Para bien o para mal siempre saben la respuesta.

No te dejan el consuelo de decir: "la vida es nuestra". 
Vamos a gritar

nuestra libertad.

No dejes mover todos tus cimientos.

Intentemos, por lo menos,

no dejar caer a todos.

Los que saben la respuesta ya no están entre nosotros.

Vamos a gritar

nuestra libertad.

No dejes mover todos tus cimientos.

\section{"Yo soy tu bandera" \\ Letra: Miguel Abuelo \\ Los Abuelos de la Nada \\ Vasos y Besos (1983)}

Hombres libres...

Libertad,

hermana de los amigos

Libertad,

nada me ata y estoy vivo.

No te mueras nunca,

Libertad.

Libertad,

socia de los peregrinos.

Libertad,

luz, coraje,

amor divino

con el corazón.

Quien no te comprende

te vulnera, novia de Dios.

Libertad,

arte de los decididos.

Libertad,

nada me ata y sigo vivo,

yo soy bandera,

Libertad.

"Su, me robaste todo"

Letra: Miguel Mateos.

Zas

Huevos (1983)

$\mathrm{Su}$, me robaste todo.

$\mathrm{Su}$, me convertiste en lodo.

Y tuve que especular

con dinero inmoral.

$\mathrm{Su}$, siete años a tu antojo.

Invertí y perdí, fuera de mí.

$\mathrm{Su}$, mi mente aún trabaja.

$\mathrm{Su}$, aunque no des ventaja.

No me podrás quebrar,

ni vender, ni comprar.

$\mathrm{Su}$, soy clase media baja.

En tanto, mi canto

se parte con el llanto

del pibe que vende Geniol.

Espero y quiero

que el mundo,

el mundo entero

sepa de mi dolor por...

$\mathrm{Su}$, vas a pedir la hora.

$\mathrm{Su}$, tu cama no enamora. 
Me mandaste a pelear

contra Neptuno en la mar

$\mathrm{Su}$, láser versus boleadoras.

Lennon, León, un solo corazón.

Hay mucho en juego

hay un destino nuevo.

Y ollas para destapar.

Hay ganas, hay onda

que nadie más se esconda

por miedo a andar con la verdad.

Su, Mambrú,

se va a pasar al club

de los que aman la libertad

tan solo libertad,

$\mathrm{Su}$.

\section{"No me dejan salir"}

\section{Charly García}

\section{Letra: Charly García}

Clics Modernos (1983)

Estoy verde, no me dejan salir.

Estoy verde, no me dejan salir.

No puedo largar, no puedo salir

no puedo sentir amor a este sentimiento

tengo que volverte a ver.

Tengo que volverte a ver.

No puedo salir

por amor a este sentimiento.

Estoy verde, no me dejan salir

estoy verde, no me dejan salir.

No puedo pensar, no puedo vivir.

No puedo pensar si amor es un

pensamiento,

tengo que volverte a ver.
Tengo que volverte a ver.

No puedo perder, por amor a ese

sentimiento.

Tengo que confiar en mi amor, tengo que confiar en mi sentimiento.

Tengo que confiar en mi amor, tengo que confiar en mi sentimiento.

Ya no sirve vivir para sufrir.

Te das cuenta, sacate el mocasín.

No puedo calmar, no puedo parir

no puedo esperar mil años que cambie el

viento.

Tengo que volverte a ver.

Tengo que volverte a ver

No puedo perder, por amor a ese

sentimiento.

Tengo que confiar en mi amor

tengo que confiar en mi sentimiento.

\section{"Viaje a la libertad"}

\section{La torre}

\section{Letra: Patricia Sosa}

Viaje a la libertad (1983)

Si me encierran porque grito

y no me dicen por qué.

Y me gritan porque pienso,

me quieren enloquecer.

¿Quién me responde cuando

pido que me expliquen

el por qué de tanta violencia?

¿Quién es verdugo? ¿Quién es el cazador?

¿Quién responde cuando pido que

me expliquen y no entiendo? 
Libertad, te busco y no te puedo encontrar.

Libertad, te busco y no te puedo encontrar.

Si en la Tierra está la guerra

y la guerra me hace mal.

Y si levanto los dedos

implorando por la paz.

¿Quién me responde cuando

pido que me expliquen

el por qué de tanta incoherencia?

¿Quién es verdugo? ¿Quién es el cazador?

¿Quién responde cuando pido que

me expliquen y no entiendo?

Libertad, te busco y no te puedo encontrar.

¿Quién me responde?

¡Vamos!

¿Quién me responde? ¿Quién me

responde?

Quiero saber.

Si censuran la ignorancia

y no se puede estudiar.

Promocionan aire libre,

no se puede respirar.

¿Quién me responde cuando

pido que me expliquen

el por qué de tanta incoherencia?

¿Quién es verdugo? ¿Quién es el cazador?

¿Quién responde cuando pido que

me expliquen y no entiendo?

Libertad, te busco y no te puedo encontrar.
¿Quién me responde cuando

pido que me expliquen

el por qué de tanta violencia?

¿Quién es verdugo? ¿Quién es el cazador?

¿Quién responde cuando matan?

¿Quién responde cuando hieren?

¿Quién responde si fusilan la esperanza

que no alcanza?

No sé.

\section{"Ellos nos han separado"}

Virus

Letra: Federico Moura-Julio Moura

Agujero interior (1983)

Hermano, quiero apretarte la mano.

Sabemos, que ellos nos han separado.

Parece se un mal general

que va haber que solucionar.

Tenés que estar en cualquier lugar

que pronto vamos a encontrar.

Lo quiero, esto es lo que yo quiero.

Mañana, para que exista mañana.

Porque la noche tiene final,

la vida vuelve siempre a cantar.

Con su pedazo de libertad

amigos míos una vez mas.

Para poder cantar, bailar.

Para poder amar, gozar.

Para poder reír, llorar.

Tengo que estar con vos de nuevo,

Porque eso es lo que yo quiero.

Mañana, para que exista mañana. 
Porque la noche tiene final,

la vida vuelve siempre a cantar.

Con su pedazo de libertad amigos míos una vez más.

\section{"Jugando Hulla - Hulla"}

\section{Los Twist}

\section{Letra: Pipo Cipolatti - Daniel Melingo}

\section{La dicha en movimiento (1983)}

Hulla Hulla está en las calles

y en los kioscos de tu barrio.

Y ya comenta la gente:

" ¡Ay! que juego tan raro"

Apurate a conseguir el tuyo

que en mi kiosco ya está agotado.

Todos tienen ya su aro

con el movimiento centro-americano.

Hulla Hulla en las veredas.

Hulla Hulla en las escuelas.

Hulla Hulla en las canchas.

Hulla Hulla ya se juega.

Si querés tener levante,

tenés que aprender el juego

con la pelvis bamboleante.

Que se marquen bien los huevos.

Hay que ver cuando bailan las chicas

revoleando las polleras,

con la argolla en la cintura.

Yo me tiro al piso, esto es la locura.

Hulla Hulla en los bares

$\mathrm{y}$ en los 36 billares.
Hulla Hulla en los clubes,

en el cielo y en las nubes.

\section{"Libertad de pensamiento"}

\section{Alejandro Lerner}

\section{Letra: Alejandro Lerner}

Lernertrés (1984)

Perros y gatos, seres humanos.

Todos buscamos libertad.

Armas de fuego, juego de manos.

Ya no se equivoquen más.

No juguemos a ser malos,

No me mates soy tu hermano.

Libertad.

Tóquense las manos, nadie es tan distinto.

No hay nadie que no quiera amar.

Saquéense los guantes, rompan las caretas.

Toquémonos con libertad.

No juguemos a ser malos,

No me mates soy tu hermano.

Libertad, Libertad

Libertad para elegir y actuar.

Para compartir con los demás.

Libertad para los hombres.

Libertad de Libertad,

Libertad para crecer en paz.

Para sonreírle a los demás.

Libertad de pensamiento.

Libertad de libertad

Libertad de libertad

No juguemos a ser malos.

No me mates soy tu hermano 
Libertad, Libertad

Libertad para elegir y actuar.

Para compartir con los demás.

Libertad para los hombres

Libertad de Libertad

Libertad para crecer en paz

Para sonreírle a los demás

Libertad de pensamiento

Libertad de libertad.

\section{"Demoliendo hoteles"}

\section{Charly García}

Letra: Charly García

Piano bar (1984)

Yo que nací con Videla

yo que nací sin poder.

Yo que luché por la libertad

y nunca la pude tener.

Yo que viví entre fascistas,

yo que morí en el altar.

Yo que crecí con los que estaban bien, pero a la noche estaba todo mal.

Hoy pasó el tiempo,

demoliendo hoteles.

Mientras los plomos juntan los cables, cazan rehenes.

Hoy pasó el tiempo

demoliendo hoteles.

Mientras los chicos allá en la esquina pegan carteles.

Yo fui educado con odio y odiaba la humanidad.

Un día me fui con los hippies

y tuve un amor y también mucho más.

Ahora no estoy más tranquilo.

¿Y por qué tendría que estar?

Todos crecimos sin entender

y todavía me siento un anormal.

Hoy pasó el tiempo,

demoliendo hoteles.

Mientras los plomos juntan los cables

cazan rehenes.

Hoy pasó el tiempo

demoliendo hoteles.

Mientras los chicos allá en la esquina pegan carteles.

“¿Dónde estás guardada?”

María Rosa Yorio

Letra: María Rosa Yorio

Por la vida (1984)

¿Dónde vas tan sola, dónde?

¿Dónde vas tan loca, hoy?

¿Quién te roba el sueño?

¿Y quién te escondió lejos?

¿Dónde estás guardada, Libertad?

Te ves tan cansada de esperar

¿Dónde te podemos visitar?

A quien te roba el sueño

se le va acabando el sueño

¿Dónde estás guardada, Libertad?

Una canción te reclama 
es casi del alma el grito

que te está buscando

y que nos va a contar

Donde estás guardada, Libertad

Debajo de muchas botas

entre el miedo y el silencio

allí estás muriendo

pero siempre dentro nuestro

Siempre estás naciendo, Libertad

Allí estás muriendo

pero siempre dentro nuestro

siempre estás volviendo, Libertad.

"Manifestación de escépticos"

Sueter

Letra: Miguel Zavaleta

Lluvia de gallinas (1984)

Monumento, yo para el amor y la libertad.

Monumentos para el que te busque

$\mathrm{y}$ te logre en paz.

Sos lo más grande, más grande del mundo.

Sos lo más grande del...

Hay va un dólar, lo persigue una

manifestación.

$\mathrm{Y}$ a ese hombre bueno le robaron hasta el pantalón.

Yo sé que la gente esta cansada,

ahora quiere disfrutar.

Ya no somos los mismos de hace algunos unos años atrás.

SÉ de muchos que quieren pan, pero

(pampero) no quieren circo.

El maquinazo es un fracaso ya se

demostró.

Él no pudo ver que alguna vez

alguien tenga un poco de esperanza como vos.

Sos lo más grande, libertad más grande, más grande, más grande del mundo.

Sos lo mas grande, libertad mas grande, mas grande del...

Ahí va Moria la persigue una manifestación y a ese hombre bueno le robaron hasta el camisón.

Yo sé que la gente esta cansada ahora quiere disfrutar, ya no somos los mismos de hace algunos unos años atrás.

Sé de muchos que quieren pan, pero (pampero) no quieren circo.

Alguien no puede ver alguien no quiere creer alguien no puede sentir que vos sos...

Alguien no quiere ver alguien no puede creer alguien no puede sentir que vos sos...

Sos lo más grande, libertad más grande, más grande, más grande del 
mundo

Sos lo más grande, libertad

más grande, más grande

ii iLibertad!!!!

\section{"Dietético"}

Soda Stereo

\section{Letra: Gustavo Cerati-Zeta Bosio}

\section{Soda Stereo (1984)}

Dietético, dietético.

Somos un conjunto dietético,

giramos una onda dietética.

Canciones de amor con sacarina,

con menos de una caloría.

Dietético, dietético,

somos un conjunto dietético.

Mejoramos un mensaje genético.

Sacude tu cuerpo libre,

consume que no hay peligro (peligro).

Dietético, dietético,

somos un conjunto dietético.

Buscando el paraíso estético.

Nuevas mentes descremadas,

siluetas de gimnasia jazz.

Dietético, dietético,

viviendo una nada dietético,

soñando con una cama sintética.

Te quiero pero estás tan gorda

presiento que no sos moderna (moderna) ¡se acabó!

El régimen se acabó,

¡se acabó!

\section{"Sin disfraz" \\ Virus \\ Letra: Federico Moura-Roberto Jacoby \\ Locura (1985)}

A veces voy donde reina el mal.

Es mi lugar, llego sin disfraz.

Por un minuto abandono el frac

y me descubro en lo espiritual,

para amar.

Como si fuera

mentiroso y nudista.

En taxi voy, hotel Savoy y bailamos.

$Y$ ya no se si es hoy, ayer o mañana.

Fue ayer.

Persiste el olor

de esa piel morena y sensual,

perfumada.

Y hoy me visto demodé y normal,

no me preocupa parecer vulgar.

Como si fuera

mentiroso y nudista.

En taxi voy, hotel Savoy y bailamos.

$\mathrm{Y}$ ya no sé si es hoy ayer o mañana.

El régimen se acabó, 
"Foto de una jaula"

\section{Sueter}

\section{Letra: Miguel Zavaleta}

20 caras bonitas (1985)

Día, explota ya el día.

$\mathrm{Y}$ yo estoy caminando

buscando algún refugio donde estar y poder gritar ausente.

\section{Y delirar}

sentado en una silla

e irme del fracaso.

Yo solo quiero verte sonreír

que algo tengo en claro.

Libre, quiero estar libre

recorrerlo todo

o mirarlo en la televisión.

Huyo, si me gritas yo huyo.

No creo en tu pelea,

yo solo quiero libertad

hasta para escaparme.

Quiero, hacer lo que yo quiero

ser nada de nada

tirado todo el día, imaginar

que fuera para todos.

Libre, olvidarme del pasado

estar obsesionado

por la maldad y la estupidez

Siempre ser dueño de mi tiempo

para suicidarme

o para espiarte cuando te cambies $\mathrm{o}$ adorarte un poquito

Libre, olvidarme del pasado

estar obsesionado

por la maldad y la estupidez

Libre o dentro de una jaula libre todo el tiempo

ya así cunado quiera, así cuando quiera

llegue el fin.

\section{"Alguna vez voy a ser libre"}

\section{Fito Páez}

\section{Letra: Fito Páez}

Giros (1985)

No soy un pez, ni un arlequín, ni un extranjero.

No tengo edad para morir, amo este cielo.

No voy a esperar, alguna vez voy a ser libre.

Libre mi amor, como el amor, como quisiste.

Voy silbando bajo y siento tu voz así.

Una sirena de ambulancia.

Voy quedando solo cada vez más, ¿y qué?

mi corazón ya no me basta.

Veo el reloj, veo las seis y voy hasta el baño.

Ya amaneció y cerca de aquí comen el barro.

Tengo que hacer, tengo que dar lo que más pueda dar.

Ya anocheció y cerca de aquí tengo las pruebas.

Panorama para mí, para vos, por él, 
por los que fueron y vinieron.

Panorama enfermo en contradicción

y yo, yo ya estoy listo como un perro.

Tengo un pasaporte en el bolsillo para irme

de acá,

tengo una canción en la cabeza y no puedo parar.

Tengo que salir, debe haber forma de resucitar.

Creo que estoy cerca mientras vos te alejes más y más.

Porque yo no tengo mapa en este mundo, porque yo doy vueltas sobre el mismo punto.

Porque yo no tengo mapa en este mundo no tengo mapa en este mundo, no.

\section{"Soy donde voy"}

GIT

\section{Letra: Pablo Guyot-Alfredo Coth-Willy \\ Iturri}

GIT II (1985)

Abriendo puertas y saltando para allá.

Lleno de tanto aire y tanto que contar.

Y quise más, más que respirar,

Quise tantas cosas más.

Pinte mi cara y seca y canto y lo demás.

Cruce Bolivia y fui al polo a patinar.

Y quise más, más que nada más

Quise tantas cosas más.

Nunca vas a ver a donde voy

Ni Mali Kathy ve a donde estoy.
Soy donde voy

Voy como voy

Soy donde estoy

Hoy donde hoy

Libertad pronto bajo un cielo tan igual.

Que de aburrido solo quise caminar.

Y quise más, más si mucho más

Solo quise tantas cosas más.

Nunca podrás creer a donde estoy,

No te imaginas de a donde soy.

Soy dónde voy

Voy como voy

Soy dónde estoy

Hoy dónde hoy

"Hay que hacer la cola"

Viudas e Hijas de Roque Enroll

Letra: Maby Díaz-María Gabriela

Epumer

\section{Ciudad catrúnica (1986)}

Hay que hacer la cola, uno adelante y otro atrás.

No hay escapatoria, todo a su tiempo y sin chistar.

Qué sensación tan espasmódica, vamos llegando y calculando la demora.

Lo que más amo es esperar, qué vibración tan sociológica. Me gusta tanto estar clavada en la baldosa, un cuerpo a cuerpo popular. 
Hay que hacer la cola,

uno adelante y otro atrás.

No hay escapatoria,

todo a su tiempo y sin chistar.

Hay que hacer la cola,

uno adelante y otro atrás.

No hay escapatoria,

todo a su tiempo y sin chistar.

Esta terapia puede ser lo más,

siempre hay Teresas que

confiesan sus historias.

Es una droga fácil de ubicar,

nadie soporta pasar cerca de una cola,

y como mínimo mirar.

Hay que hacer la cola,

uno adelante y otro atrás.

No hay escapatoria,

todo a su tiempo y sin chistar.

Hay que hacer la cola,

uno adelante y otro atrás.

No hay escapatoria,

todo a su tiempo y sin chistar.

Nadie adelante, sólo uno atrás,

primer lugar, la ventanilla me devora,

esto es el éxtasis total.

Hay que hacer la cola,

uno adelante y otro atrás.

No hay escapatoria,

todo a su tiempo y sin chistar.

Hay que hacer la cola,

uno adelante y otro atrás.

No hay escapatoria, todo a su tiempo y sin chistar.

Hay que hacer la cola...

\section{"Acción y Reacción"}

\section{La Sobrecarga}

Letra: Gabriel Collado

Sentidos congelados (1986)

Oye, no cambies el ritmo de hoy.

Oye, no cambies el ritmo.

Vamos corriendo sin dirección,

estamos buscando

una nueva visión.

Cuando reacciones,

cuando reaccione.

Vivir temiendo un nuevo dolor

aumenta el tedio,

destruye la acción.

Hay algo oculto

en el ritmo de hoy.

Un ritmo nuevo

de acción y reacción.

Cuando reacciones,

Cuando reaccione.

Un ritmo nuevo

de acción y reacción,

un mundo nuevo

de acción y reacción. 
"Héroes anónimos"

Metrópoli

\section{Letra: Ulises Butrón}

Viaje al más acá (1986)

Estamos atrapados en la misma red.

Viajando por un laberinto.

Estamos sosteniendo una pared.

Por favor, no las dejes caer.

Ceferino no me escucha más

¿Adónde fue la Madre María?

Aunque no crea en la casualidad,

Sueño con Loterías.

Todos somos Héroes Anónimos.

Guerreros en este lugar,

peleando con el corazón.

Combatiendo tanta soledad.

Me bombardean otra vez,

vuelvo a construir mi casa.

Como una fuerza del más allá, encuentro en tu mirada.

Todos somos Héroes Anónimos.

Guerreros en este lugar,

peleando con el corazón.

Combatiendo tanta soledad.

Héroes Anónimos.

"Nunca podrán sacarme mi amor"

Fito Páez

\section{Letra: Fito Páez}

Corazón clandestino (1986)
Puedes decirme que si, puedes decirme que no.

Pero nunca podrás sacarme mi amor.

Puedes quemarme los pies,

puedes dejarme sin voz,

Pero nunca podrás sacarme mi amor.

Y si es folklore o si no,

y si es Urano o Plutón.

Pero nunca podrán sacarme mi amor.

Ni un analista, ni un doctor

ni un cura, ni un doctor

te solucionan los problemas.

La gente busca una razón

yo estoy buscando una canción

que me sacuda la cabeza.

Y poder verte feliz

cuando acá todo es un bajón.

Pueden vender un país

y estar del lado de Dios.

Pero nunca podrás sacarme mi amor.

Ni un analista, ni un doctor,

ni Stubrin, ni el gobernador

te solucionan los problemas.

La gente busca una razón

yo estoy buscando un rock \& roll

que me sacuda la cabeza.

Puedes echarme de aquí

por no pensar como vos.

Pero nunca podrás sacarme mi amor. 
"Prófugos"

Soda Stereo

\section{Letra: Gustavo Cerati}

\section{Signos (1986)}

Somos cómplices los dos.

Al menos sé que huyo porque amo.

Necesito distensión

Estar así despierto

es un delirio de condenados.

Como un efecto residual, yo siempre tomare el desvío.

Tus ojos nunca mentirán, pero ese ruido blanco

es una alarma en mis oídos.

No seas tan cruel

No busques más pretextos.

No seas tan cruel

Siempre seremos prófugos, los dos

No tenemos dónde ir.

Somos como un área desvastada.

Carreteras sin sentido.

Religiones sin motivo

¿Cómo podremos sobrevivir?

No seas tan cruel

No busques mas pretextos

No seas tan cruel

Siempre seremos

Siempre seremos prófugos, los dos

Ven

No seas tan cruel

No busques más pretextos

No seas tan cruel
Siempre seremos prófugos

Siempre seremos prófugos.

\section{"Nada me detiene"}

\section{La Torre}

\section{Letra: Patricia Sosa}

Presas de caza (1986)

Sola y triste en la mañana, tengo que prender la luz.

Desnuda, roja mi cama, tengo que ver la razón.

Salí a la calle decidida a cualquier cosa, mientras los buitres no dejaban de volar. Toda esa gente que nos mira enloquecida, no entiende la libertad.

Pensando caminar un rato, tú verás a la ciudad.

Mientras Buenos Aires duerme, mi cuerpo despierto está.

Salí a la calle decidida a cualquier cosa, mientras los buitres no dejaban de volar. Toda esa gente que nos mira enloquecida, no entiende la libertad.

Nada me detiene, nada me detiene, nada me detiene, porque nada, nada nos puede parar. Nada me detiene, nada me detiene, nada me detiene, porque nada, nada nos puede parar.

Porque soy mucho más 
que un par de lindas piernas.

Corazón total,

si no es el momento de estar alerta.

Salí a la calle decidida a cualquier cosa, mientras los buitres no dejaban de volar. Toda esa gente que nos mira enloquecida, no entienden la libertad.

Nada me detiene, nada me detiene, nada me detiene, porque nada, nada nos puede parar.

Nada me detiene, nada me detiene, nada me detiene, porque nada, nada nos puede parar.

Nada me detiene, nada me detiene, nada me detiene, porque nada, nada, nada nos puede parar.

\section{"Planeta Agua"}

\section{Los Encargados}

Letra: Daniel Melero

Silencio (1986)

Cómplice del miedo me mirás como idiota.

Puedo hablar en serio.

Mañana estaré muerto.

Sé que tus labios me descargan al vacío.

El metal puede ser frío pero al menos es mi antojo.

Agua planeta

Ya no hay silencio.

Se desborda el caudal.

El origen se dispersa en la compleja red eléctrica.

Trato de agruparme y los destinos penden y se aflojan.

Es inevitable el abismo se aproxima,

Agua planeta.

\section{"Los viejos vinagres"}

Sumo

\section{Letra: Luca Prodan-Roberto Pettinato}

Llegando los monos (1986)

Dale, dale con el look, pero no te mires como Captain Cook, dale, dale con el look, pero no te mires como Captain Cook.

Para vos lo peor es la libertad, para vos lo peor es la libertad.

Estoy rodeado de viejos vinagres, ¡todo alrededor!

Estoy rodeado de viejos vinagres ¡todo alrededor!

No te olvides de posar en la disco o en el bar, no te olvides de posar en la disco o en el bar. Para vos lo peor es resbalar, para vos lo peor es resbalar.

Estoy rodeado de viejos vinagres ; todo alrededor! Estoy rodeado de viejos vinagres ¡todo alrededor! 
Juventud, divino, tesoro.

Juventud, divino, tesoro.

"Libre vivir"

Zas/Miguel Mateos

Letra: Miguel Mateos

Solos en América (1986)

Soñar, jugar

es cuestión de diferenciar

la libertad con el delirio.

Tocar, no estar.

Una sombra en mi habitación

escribe tu nombre sobre un vidrio.

Quiero libre vivir.

Quiero libre vivir.

El problema está en compartir.

Quiero, quiero, quiero

libre vivir.

Vibrar, cantar.

Todavía yo tengo fe

en cosas que ya nadie cree.

Amar, volver a empezar

y tener esa sensación

de estar jugando con fuego.

Quiero libre vivir.

Quiero libre vivir.

El problema está en compartir

quiero, quiero, quiero... y estoy seguro que,

en pocas horas más,

no me podré sostener.

Sin ganas de seguir.

Te veré partir

y abriré tu carta

que me dice:

"Quiero libre vivir."

Quiero libre vivir

el problema está en compartir

quiero, quiero, quiero

libre vivir.

Solo quiero, solo quiero, libre vivir solo quiero, solo quiero, libre vivir solo, solo, solo, solo, libre vivir libre vivir, solo quiero.

\section{"El rosario en el muro"}

Don Cornelio y la Zona

\section{Letra: Palo Pandolfo}

Don Cornelio y la Zona (1987)

Aquella mañana él se despertó, casi sin aliento con mucha tos.

El rosario en el muro, sos esclavo de Dios.

El rosario en el muro

maldito pecador.

Mamá respiraba, tenía pulso.

Casi sin aliento, los senos sueltos.

El rosario en el muro.

Hijo mío, sos esclavo de Dios.

Estoy perdiéndote 
El rosario en el muro

madre, quiero tu sexo.

Corre y sube la escalera ya,

y ajusta tu corbata.

Aunque llores, reces y te humilles nene

la salida de tu vida es la caída.

Si ya estas en la azotea, salta

si ya estas en la azotea, salta.

Aquella mañana la calle tembló, destruir tu cuerpo es liberación.

El rosario en el muro

quién me habla, no entiendo, no señor.

El rosario en el muro

¡No, no, no!

Un escalón y tus rodillas rojas.

Dos escalones y tu grito en las astillas.

Tres escalones y tus recuerdos.

Cuatro escalones y el viento y...

Si ya estas en la azotea, salta.

Si ya estás en la azotea, salta.

Después de esta vida loca

para que seguir así nene salta.

\section{"Rodillas"}

María Rosa Yorio

Letra: María Rosa Yorio

Rodillas (1987)

No olvides tus rodillas, no, si querés bailar algo como el jazz, nene.

Juego tonto dicen por ahí, no está nada mal.

Se acabó el blah blah, ¡oigan!

Rodillas en el suelo, si, en el aire van juntas con papá, papá.

Lastímalas un poco, así es como jugar.

Stop con escapar.

Arrastrándolas como un bebé mundo nuevo para ver

Yo les dije déjenme jugar ¿es tan caro el precio de la libertad?

Tienes la noche

para viajar

en tus rodillas

así que ya no puedes parar

Baila, baila, baila con el rock con rodillas y con tu corazón.

Arribas las polleras y

todas a girar, todas a bailar.

Juego sucio dicen por ahí

pero hasta el amor

empieza por jugar

Y no pagues ni un peso más ese caro precio de la libertad

No olvides tus rodillas, no

si querés bailar algo como el jazz. 
"Yo no me sentaría en tu mesa"

Los Fabulosos Cadillacs

Letra: Vicentico Capello

Yo te avisé (1987)

Por más que quieran sacarnos de nuestro lugar y pienses que solo somos un puñado de idiotas.

No podrás quitarnos lo que hicimos ya, ahora somos más hermanos que antes. Ya no podrás mirarnos a los ojos más.

Nosotros somos amigos, vos que solo estás. Por más que quieras tapar toda nuestra voz, nunca podrás callar esta canción.

Y si después no crees lo que te estoy diciendo, mirá mis pies bailando al son de este ritmo.

Voy a vestirme de traje aunque me vea mal. Voy a saltar toda la noche sin parar de silbar.

Está lloviendo, pero yo no me voy a mojar. Mis amigos me cubren cuando voy a llorar, por más que quieras tapar toda nuestra voz, nunca podrán callar esta canción.
"Siento Llegar"

Fabiana Cantilo

\section{Letra: Gabriel Carámbula}

Fabiana Cantilo y los perros calientes (1988)

Yo no llamé, al impulsador.

Nunca soñé, con verte tan bien.

Te siento latir como un corazón.

Más brillo te da tu nuevo visón. semimuerto.

Siento llegar, un antiguo olor tu capacidad desborda mi sed.

Me vas a engañar, a desvanecer. Esclavizarás cada vez más mi memoria, prometido.

Sin gravedad y sin voluntad.

Salgo a bailar con mi malestar de siempre Ya me cansé de no tener a quien matar y regalar unas flores.

Quiero usar tu libertad desmoronar mi soledad. 


\section{"Guitarras blancas"}

\section{Los Enanitos verdes}

\section{Letra: Marciano Cantero}

Carrousel (1988)

Una guitarra blanca

rompiendo el silencio.

Es de lo más honesto

que yo ahora puedo escuchar.

Por favor, déjennos bailar.

Por favor, que nos dejen bailar.

Hoy fue uno de esos días,

y me duele la espalda.

$\mathrm{Y}$ aunque estoy cansado

yo necesito un poco de diversión.

Por favor, déjennos bailar.

Por favor, que nos dejen bailar.

No hablen ahora de Nueva York, estar en Roma o Disney World,

Yo sólo quiero que nos dejen bailar acá.

No es un escapismo.

No estoy bajando la guardia.

Yo sólo necesito tan sólo

Un poco, un poco de diversión.

Por favor, déjenlos bailar.

Por favor que nos dejen bailar.

No hablen ahora de Nueva York,

Estar en Roma o Disney World,

Yo sólo quiero que nos dejen bailar acá.

\section{"Ocho ríos"}

Los Pericos

Letra: Juanchi Baleiron

King Kong (1988)

Y de Ocho Ríos,

Te escribo de Ocho Ríos.

Y de ocho ríos,

Te escribo de Ocho Ríos.

Con un cigarro en la piel te escribo.

Con un cigarro en la sien te digo.

Que en Ocho Ríos,

ya soy parte de Ocho Ríos.

Se duerme el ángel en mi corazón.

Y este sueño no, no tiene dolor.

Me quedo, me quedo para no volver.

Me quedo, me quedo, me quedo.

En Ocho Ríos.

Y de ocho ríos,

Te escribo de ocho ríos

Con esa marca en la piel,

con esa vieja mujer te digo.

Ya soy parte de Ocho Ríos.

\section{"Enjaulados"}

\section{Fricción}

\section{Letra: Richard Coleman}

Para terminar (1988)

Ya tienes tu equipo de sombra, $\mathrm{y}$ un poco de metal para desplazarte, vas a conectarte para salir. 
¿Adónde morimos hoy?

Podemos aturdirnos hasta disolvernos, en el café moderno y luego partir.

Abriendo surcos, surcos de neón.

Buscando otra celda confortable, adonde bailar, enjaulados.

Sudando el maquillaje,

bailando enjaulados, enjaulados...

Ya cambiaste mil veces de forma,

alterando tu expresión.

Y cambias el panorama,

con cada nueva canción.

Oigo un famélico,

rabioso perro eléctrico,

babeando por la radio detergente mental.

¡Apágalo, está lavando tu prisión!

¡Detergente mental!

Buscando otra celda confortable,

a donde bailar, enjaulados.

Sudando el maquillaje,

bailando enjaulados, enjaulados...

Bailando enjaulados.

\section{"Espirales"}

\section{Don Cornelio}

\section{Letra: Palo Pandolfo}

Patria o muerte (1988)

Hace tanto tiempo que quiero llegar

a tocarme la cabeza sin sentirme mal.
Me veo en la jaula, miedo animal

de seguir acá, en la calle.

Está cerca la salida,

están rotos los bolsillos,

estoy dentro de ese brillo que me llevará...

Voy a repartir entre las manos de marfil

piezas de arcilla que pulí.

Vamos, espirales,

reventemos como un cono,

como piezas de arcilla que pulí.

Hace tanto frío para respirar...

Si me suelto la cabeza,

romperé a brillar.

Creo que mi amiga

tiene cielo en los ojos,

y si vuelo hacia adentro,

llegaré hasta el mar.

Voy a repartir entre las manos de marfil

piezas de arcilla que pulí.

Vamos, espirales,

reventemos como un cono,

como piezas de arcilla que pulí.

Está cerca la salida,

están rotos los bolsillos,

estoy dentro de ese brillo que me llevará..

Creo que mi amiga

tiene cielo en los ojos,

y si vuelo hacia adentro,

llegaré hasta el mar. 
Vamos, espirales,

reventemos como un cono,

como piezas de arcilla que pulí.

"Salgamos a la calle"

Man Ray

Letra: Lito Losavio-Hilda Lizarazu

Man Ray (1988)

Prefiero gritar practicando una melodía.

Prefiero cantar antes que verla a mi tía.

Prefiero bailar desnuda en una pieza.

Tal vez está mal pero no es ninguna rareza.

Los días que vendrán prefiero disfrutar.

El tiempo no está mal,

lo veo hoy mismo.

Salgamos a la calle contentos de estar vivos

Si no que otro motivo te puede ya salvar,

Te queda por buscar.

Me quedo sola.

\section{"No me empujes"}

Andrés Calamaro

\section{Letra: Andrés Calamaro}

\section{Por mirarte (1988)}

No me importan todos tus problemas

así no te quiero conocer.

No me empujes a otro abandono,

no es un buen momento para perder.

Ya se van las luces

en el horizonte,
Todo tiene un final todo termina.

Por un momento te voy a dejar sola

no es un trago fácil para mi.

Zapatos de gamuza, zapatos de charol,

bailando al compás de la liberación.

Bailando en los rincones mas dorados de la ciudad, bailando sobre la sangre de los demás.

No me importan todos tus problemas, no me empujes a abandonarte de nuevo.

No es un trago fácil para mi,

Bailando sobre la sangre de los demás.

\section{"Edificios"}

\section{La Portuaria}

\section{Letra: Diego Frenkel}

Rosas rojas (1989)

Estás sentado frente a la TV, te sientes solo y sin nada que hacer.

Leyendo el diario, oyendo una canción.

Matando el tiempo, soñando una ilusión.

Mejor salir de los edificios,

mejor bailar que andar entre pasillos.

Te estás diciendo que todo acabará que ya no hay vida, que ya no hay verdad.

Te estás hundiendo sobre tu sofá

y estás pensando que todo acabará.

Mejor salir de los edificios

mejor bailar que andar entre pasillos.

Mejor salir de los edificios, mejor bailar que andar entre pasillos. 